\title{
WestVirginiaUniversity
}

THE RESEARCH REPOSITORY @ WVU

Graduate Theses, Dissertations, and Problem Reports

2005

\section{Numerical modeling of buried pipes with flowable fill as a backfill material}

Hemachandar Mada

West Virginia University

Follow this and additional works at: https://researchrepository.wvu.edu/etd

\section{Recommended Citation}

Mada, Hemachandar, "Numerical modeling of buried pipes with flowable fill as a backfill material" (2005). Graduate Theses, Dissertations, and Problem Reports. 4171.

https://researchrepository.wvu.edu/etd/4171

This Thesis is protected by copyright and/or related rights. It has been brought to you by the The Research Repository @ WVU with permission from the rights-holder(s). You are free to use this Thesis in any way that is permitted by the copyright and related rights legislation that applies to your use. For other uses you must obtain permission from the rights-holder(s) directly, unless additional rights are indicated by a Creative Commons license in the record and/ or on the work itself. This Thesis has been accepted for inclusion in WVU Graduate Theses, Dissertations, and Problem Reports collection by an authorized administrator of The Research Repository @ WVU. For more information, please contact researchrepository@mail.wvu.edu. 


\title{
Numerical Modeling of Buried Pipes with Flowable Fill as a Backfill Material
}

\author{
By \\ Hemachandar Mada

\begin{abstract}
Thesis submitted to the College of Engineering and Mineral Resources at West Virginia University in partial fulfillment of the requirements for the degree of
\end{abstract}

\author{
Master of Science \\ in \\ Engineering
}

\author{
Hema J Siriwardane, Ph.D., Chair \\ Udaya B. Halabe, Ph.D. \\ Roger C. Viadero, Ph.D. \\ Department of Civil and Environmental Engineering
}

Morgantown, West Virginia

2005

Keywords: Flowable Fill, Buried Pipes, Numerical Modeling 


\section{ABSTRACT \\ Numerical Modeling of Buried Pipes with Flowable Fill as a Backfill Material \\ Hemachandar Mada}

The objective of this research work was to perform a numerical analysis of pipe deformations when flowable fill is used as a backfill material around buried plastic corrugated pipes. The flowable fill materials used in this study contained varying proportions of fly ash, bottom ash, river sand, and cement. The stiffness properties of CLSM backfill materials were back calculated from experimental data obtained under various trench width ratios. The stiffness properties of HDPE pipes were calculated based on the data provided by the pipe manufacturer. Finite element models of HDPE pipes with varying trench widths were developed for laboratory conditions. The experimental variables included: trench width, pipe diameter, in-situ soil strength, backfill strength, and external loading. The numerical results were compared with that of the experimental data. In addition to modeling laboratory conditions, finite element models for 18 -inch $(45.7 \mathrm{~cm})$ and 24-inch $(61 \mathrm{~cm})$ diameter pipes were developed for field conditions. The depth of burial was varied between $20 \mathrm{ft}(6.1 \mathrm{~m})$ to $60 \mathrm{ft}(18.2 \mathrm{~m})$. An HS-20 load acting at the ground surface was considered in addition to the body forces (weight of soil). In order to evaluate the long-term structural performance of HDPE pipes, finite element analysis was carried out up to 50 years. Results show that the trench width can be reduced to 1.5 times the pipe diameter without causing pipe failure even at depths up to 50 feet $(15.25 \mathrm{~m})$. 


\section{ACKNOWLEDGEMENTS}

The author would like to take this opportunity to thank the people who helped in the completion of this thesis. The author wishes to thank Dr. Hema Siriwardane, graduate adviser and committee chairman, for his valuable guidance, which was the corner stone for this thesis. The author also thanks Dr. Udaya Halabe and Dr. Roger Viadero for their participation in the committee.

The Financial support provided by West Virginia Department of Transportation, Division of Highways for this project through a research contract to West Virginia University is gratefully acknowledged.

The author would like to thank Rajkumar Gondle and Kishan Kakarla for there help and support through out the project. The author also would like to thank family and friends for their moral support and understanding. 


\section{TABLE OF CONTENTS}

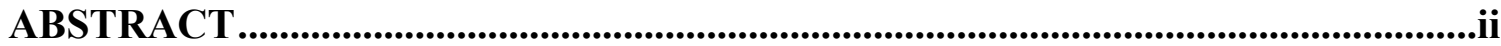

ACKNOWLEDGEMENTS .................................................................................ii

TABLE OF CONTENTS ................................................................................................... iv

LIST OF TABLES .......................................................................................................... viii

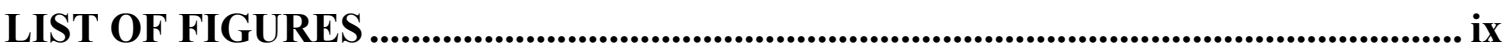

CHAPTER 1: INTRODUCTION.................................................................................. 1

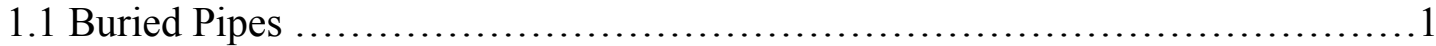

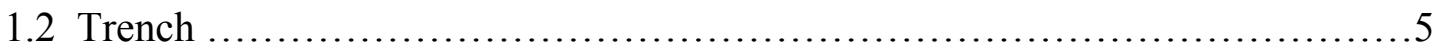

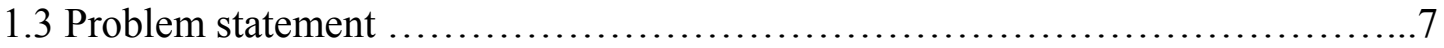

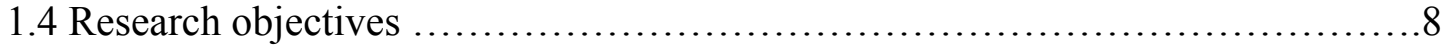

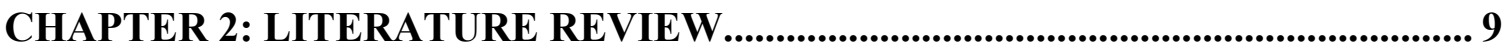

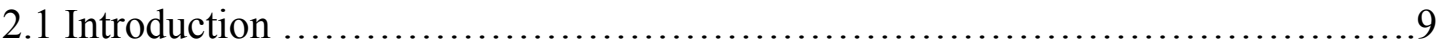

2.2 Structural response of HDPE pipes under laboratory conditions ..................

2.3 Structural response of HDPE pipes under field conditions ......................14

2.4 Influence of soil types and CLSM mixtures ................................16

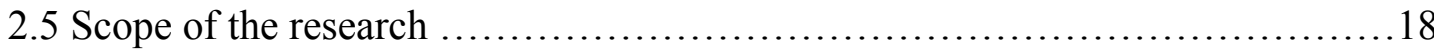

CHAPTER 3: MATERIAL PROPERTIES ........................................................ 19

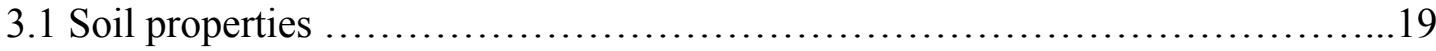

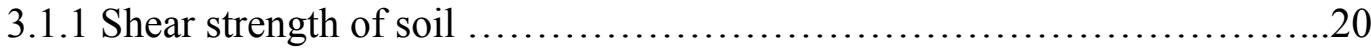

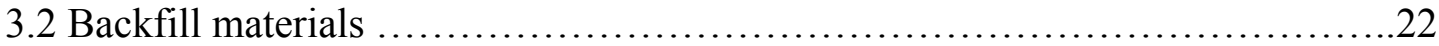

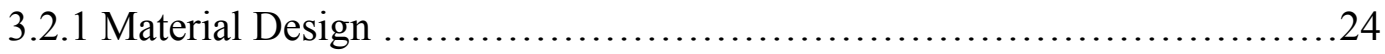

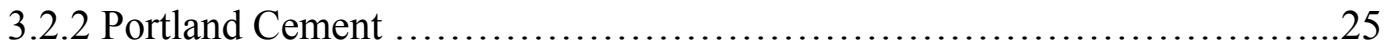

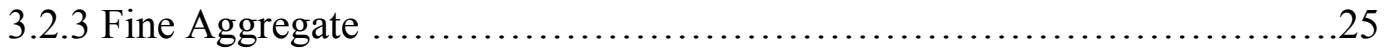

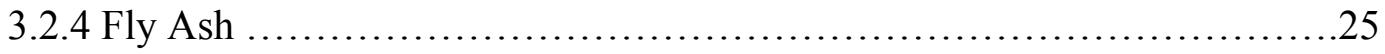

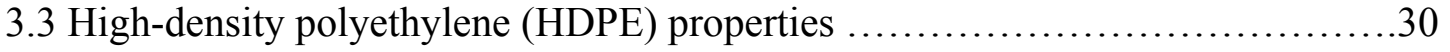

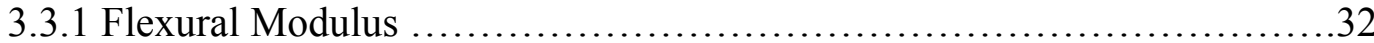

3.3.2 Flexible Pipe Design Criteria ..........................................33

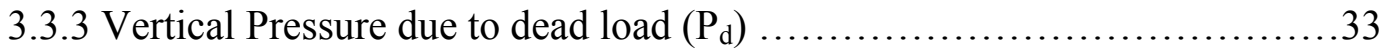

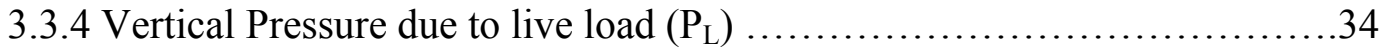

3.3.5 Deflection Equations ............................................... 37 
CHAPTER 4: NUMERICAL ANALYSIS PROCEDURES.

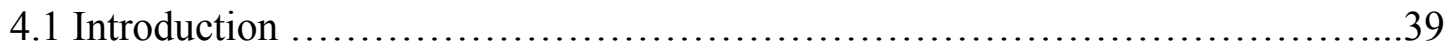

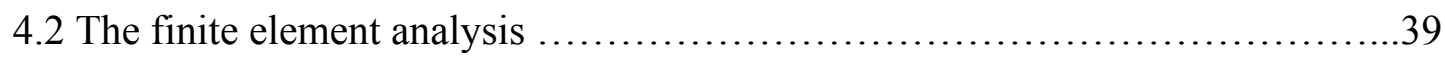

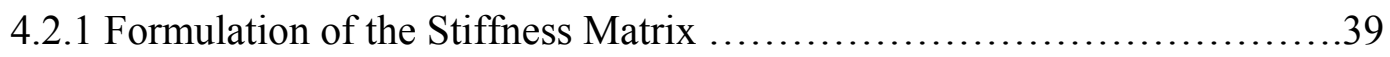

4.2.2 Four node isoparametric element formulation $\ldots \ldots \ldots \ldots \ldots \ldots \ldots \ldots \ldots . . \ldots 3$

4.2.3 Three dimensional brick element formulation .........................47

4.3 Constitutive model ............................................... 50

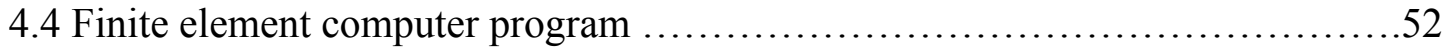

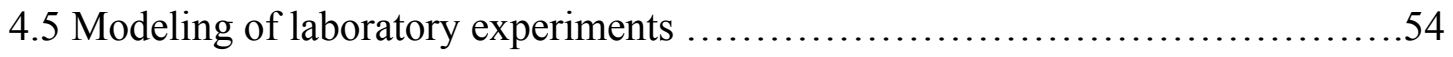

4.6 Modeling of buried pipes under field conditions ............................59

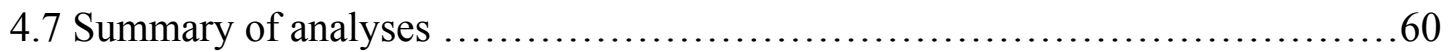

\section{CHAPTER 5: NUMERICAL RESULTS UNDER}

LABORATORY CONDITIONS ....................................................68

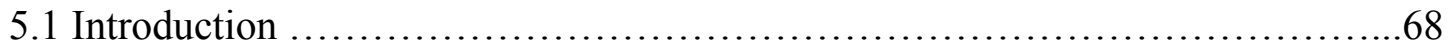

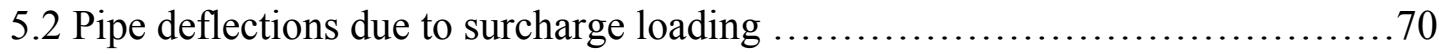

5.3 Soil stresses due to surcharge loading ................................. 81

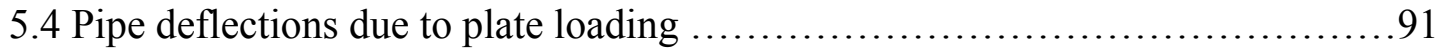

5.5 Soil stresses due to plate loading ....................................... 99

\section{CHAPTER 6: NUMERICAL RESULTS UNDER}

FIELD CONDITIONS .......................................................107

6.1 Introduction ........................................................... 107

6.2 Numerical results for HDPE pipes at 20 feet depth ........................ 107

CHAPTER 7:SUMMARY AND CONCLUSIONS .............................125

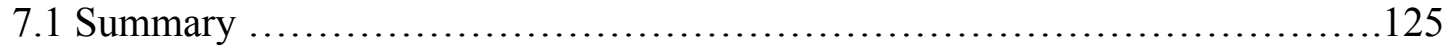

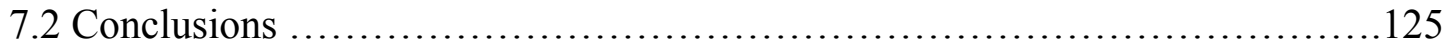

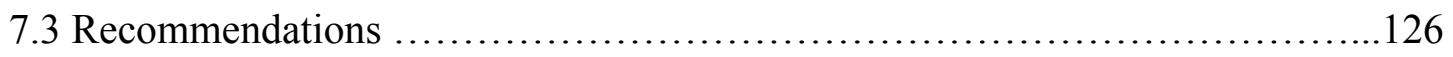

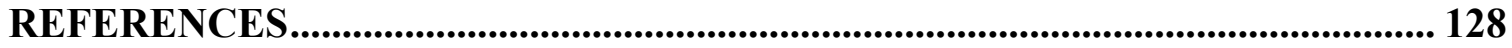

APPENDIX A: Numerical data for 6-inch and 8-inch HDPE pipes ..................134

APPENDIX B: Numerical data for 18-inch and 24-inch HDPE pipes ................143

APPENDIX C: Back calculation of CLSM stiffness properties ...............................147 


\section{LIST OF TABLES}

Table 1.1: Pipe classification based on the percentage of deflection ....................2

Table 1.2: Polyethylene design properties.....................................

Table 2.1 Comparisons for soil and CLSM-CDF as backfill........................17

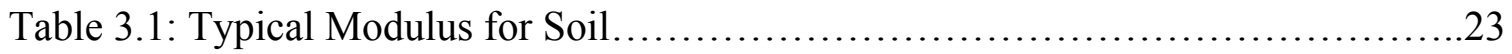

Table 3.2: Material properties for cohesive and loose in-situ soil......................24

Table 3.3: Material properties for high strength and low strength backfill................26

Table 3.4: Types of bedding materials used for backfill material....................27

Table 3.5: Degree of compaction of backfill materials.............................28

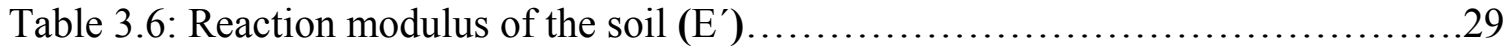

Table 3.7 Classification of PE based on density................................... 30

Table 3.8: Effects of density and molecular weight distribution on HDPE material......31

Table 3.9: Minimum pipe stiffness at various diameters............................ 35

Table 3.10: Single wall pipe section properties................................... 36

Table 3.11: Material properties for 6-inch and 8-inch diameter HDPE pipes..............37

Table 4.1: Material properties for 6-inch and 8-inch diameter HDPE pipes.............58

Table 4.2: Material properties for cohesive and loose insitu soil.....................58

Table 4.3: Material properties for high strength and low strength backfill...............59

Table 4.4: Material properties used for the analysis of a field configuration.............64

Table 6.1: Properties used for HDPE pipes under field conditions...................114 


\section{LIST OF FIGURES}

Figure 1.1: Pipe cross-section nomenclature …................................

Figure 1.2: Typical trench geometry for compacted earth............................6

Figure 1.3: Typical trench geometry for controlled low strength materials........................6

Figure 1.4: Pipe Deflections........................................................

Figure 2.1: Parallel plate test apparatus......................................... 10

Figure 2.2: Cross section of pipe hoop compression test facility.......................11

Figure 2.3: Laboratory test setup to study the response of HDPE pipe under hoop compression............................................

Figure 2.4: Buried pipe cross section............................................13

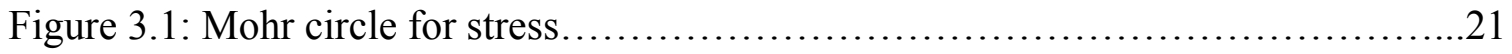

Figure 3.2: Testing apparatus to determine flexural strength..........................32

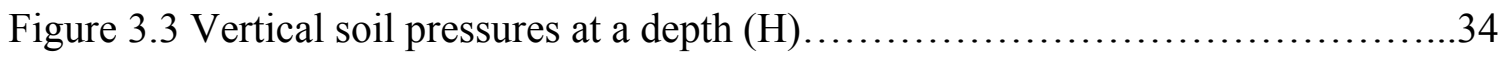

Figure 4.1: Four node isoparametric element....................................41

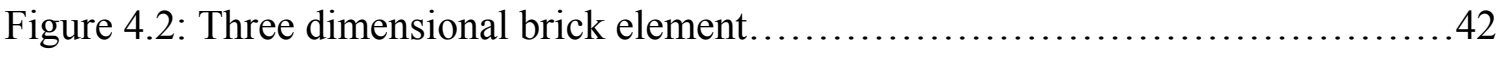

Figure 4.3: Nodal displacements along $\mathrm{x}$ and $\mathrm{y}$ direction for isoparametric element......43

Figure 4.4: Nodal displacements along $\mathrm{x}$ and $\mathrm{y}$ directions for solid element............47

Figure 4.5: Steps involved in finite element analysis.............................5 53

Figure 4.6: Schematic diagram of the testing apparatus.............................5 54

Figure 4.7: HDPE pipe model under uniform surcharge loading .......................55

Figure 4.8: HDPE pipe model under plate loading.................................55

Figure 4.9: Typical cross-section of a pipe ......................................56

Figure 4.10: Schematic diagram of the finite element model under field conditions......61

Figure 4.11: Schematic diagram of three dimensional finite element model under field condition...................................62

Figure 4.12: HDPE pipe model subjected to HS20 loading under field conditions........63

Figure 4.13: Pipe analysis layout for 6 inch and 8 inch HDPE pipes...................65

Figure 4.14: Pipe analysis layout for 18 inch and 24 inch HDPE pipes..................67

Figure 5.1: Schematic diagram of HDPE pipe under Surcharge loading..................69

Figure 5.2: Schematic diagram of HDPE pipe under plate loading.......................69 
Figure 5.3: Pipe deflections under surcharge loading of the 6-inch pipe in cohesive insitu soil with low strength backfill...............................72

Figure 5.4: Pipe deflections under surcharge loading of the 6-inch pipe in cohesive insitu soil with high strength backfill.............................73

Figure 5.5: Pipe deflections under surcharge loading of the 6-inch pipe in loose insitu soil with low strength backfill.................................74

Figure 5.6: Pipe deflections under surcharge loading of the 6-inch pipe in loose insitu soil with high strength backfill..................................75

Figure 5.7: Pipe deflections under surcharge loading of the 8-inch pipe in cohesive insitu soil with low strength backfill............................76

Figure 5.8: Pipe deflections under surcharge loading of the 8-inch pipe in cohesive insitu soil with high strength backfill............................77

Figure 5.9: Pipe deflections under surcharge loading of the 8-inch pipe in

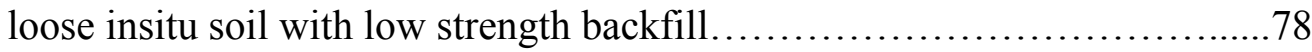

Figure 5.10: Pipe deflections under surcharge loading of the 8-inch pipe in loose insitu soil with high strength backfill................................79

Figure 5.11: Soil-pipe deformation contours for of the 8-inch pipe with trench width ratio of 2 under surcharge loading of $20 \mathrm{psi} \ldots \ldots \ldots \ldots \ldots \ldots . . . . . . .80$

Figure 5.12: Location of pressure cell under the centerline of the pipe...................82

Figure 5.13: Schematic diagram of Negative Arching................................83

Figure 5.14: Schematic diagram of Positive Arching.................................83

Figure 5.15: stresses under surcharge loading of the 6-inch pipe in cohesive insitu soil with low strength backfill............................. 84

Figure 5.16: stresses under surcharge loading of the 6-inch pipe in

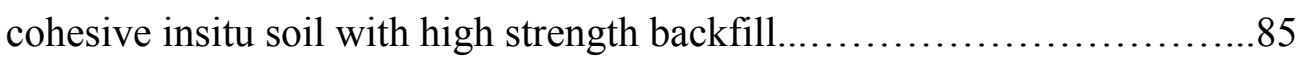

Figure 5.17: stresses under surcharge loading of the 6-inch pipe in loose insitu soil with low strength backfill................................ 86

Figure 5.18: stresses under surcharge loading of the 8-inch pipe in cohesive insitu soil with low strength backfill

Figure 5.19: stresses under surcharge loading of the 8-inch pipe in cohesive insitu soil with high strength backfill. 
Figure 5.20: stresses under surcharge loading of the 8-inch pipe in

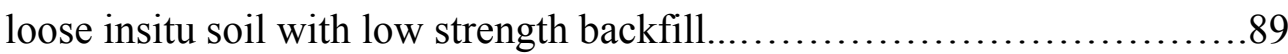

Figure 5.21: Von mises stress for the 6-inch and the 8-inch pipe under a surcharge loading of $30 \mathrm{psi}$ with low CLSM backfill.....................90

Figure 5.22: Pipe deflections under plate loading of the 6-inch pipe in cohesive insitu soil with low strength backfill

Figure 5.23: Pipe deflections under plate loading of the 6-inch pipe in cohesive insitu soil with high strength backfill.....

Figure 5.24: Pipe deflections under plate loading of the 6-inch pipe in loose insitu soil with low strength backfill...............................94

Figure 5.25: Pipe deflections under plate loading of the 8-inch pipe in cohesive insitu soil with low strength backfill .95

Figure 5.26: Pipe deflections under plate loading of the 8-inch pipe in cohesive insitu soil with high strength backfill. .96

Figure 5.27: Pipe deflections under plate loading of the 8-inch pipe in loose insitu soil with low strength backfill.

Figure 5.28: Soil-pipe deformation contours for the 8-inch pipe with a trench width ratio of 2 under a $2000 \mathrm{lb}$ plate load........................98

Figure 5.29: Location of pressure cell under the centerline of the pipe

Figure 5.30: stresses under plate loading of the 6-inch pipe in cohesive insitu soil with low strength backfill

Figure 5.31: stresses under plate loading of the 6-inch pipe in cohesive insitu soil with high strength backfill

Figure 5.32: stresses under plate loading of the 6-inch pipe in loose insitu soil with low strength backfill. .102

Figure 5.33: stresses under plate loading of the 8-inch pipe in cohesive insitu soil with low strength backfill

Figure 5.34: stresses under plate loading of the 8-inch pipe in cohesive insitu soil with high strength backfill. 104

Figure 5.35: stresses under plate loading of the 8-inch pipe in loose insitu soil with low strength backfill. 105 
Figure 5.36: Vertical stress contours for the 8-inch pipe with trench width ratio of 2 under a plate loading of $2000 \mathrm{lb} \ldots \ldots \ldots \ldots \ldots \ldots$

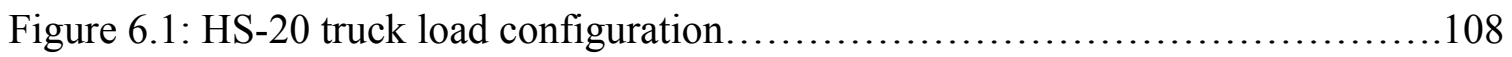

Figure 6.2: Variation of vertical pipe deflection with time for the 18 -inch pipe at 20 feet depth.

Figure 6.3: Variation of vertical pipe deflection with time for the 24 -inch pipe at 20 feet depth................................ 110

Figure 6.4: Vertical displacements of the 24-inch pipe at 20 feet depth.

Figure 6.5: Solid Von Misses Stress contours of the 24-inch

HDPE pipe at 20 feet.

Figure 6.6: Buried pipe model without Interface

Figure 6.7: Buried pipe model with Interface.

Figure 6.8: Variation of pipe deflection with depth for the 18-inch HDPE pipe.

Figure 6.9: Variation of pipe deflection with depth for the 24-inch HDPE pipe.

Figure 6.10: Variation of deflection with depth of the 18-inch HDPE pipe with interface for a trench width ratio, $\left(\mathrm{N}_{\mathrm{r}}\right)=1.5$.

Figure 6.11: Variation of deflection with depth of the 18-inch HDPE pipe with interface for a trench width ratio, $\left(\mathrm{N}_{\mathrm{r}}\right)=2$

Figure 6.12: Variation of deflection with depth of the 18-inch HDPE

pipe with interface for a trench width ratio, $\left(\mathrm{N}_{\mathrm{r}}\right)=2.5$.

Figure 6.13: Variation of deflection with depth of the 18-inch HDPE pipe with interface for a trench width ratio, $\left(\mathrm{N}_{\mathrm{r}}\right)=3$.

Figure 6.14: Variation of deflection with depth of the 24-inch HDPE pipe with interface for a trench width ratio, $\left(\mathrm{N}_{\mathrm{r}}\right)=1.5$

Figure 6.15: Variation of deflection with depth of the 24-inch HDPE pipe with interface for a trench width ratio, $\left(\mathrm{N}_{\mathrm{r}}\right)=2$

Figure 6.16: Variation of deflection with depth of the 24-inch HDPE pipe with interface for a trench width ratio, $\left(\mathrm{N}_{\mathrm{r}}\right)=2.5$.

Figure 6.17: Variation of deflection with depth of the 24-inch HDPE pipe with interface for a trench width ratio, $\left(\mathrm{N}_{\mathrm{r}}\right)=3$ 


\section{CHAPTER 1 \\ INTRODUCTION}

\subsection{Buried Pipes}

From the dawn of civilization, underground conduits have served in miscellaneous applications such as sewer lines, drain lines, water lines, culverts, oil pipe lines, coal slurry lines, subway tunnels and heat distribution pipe lines, improving the standard of living. The use of engineering science with degree of precision has improved the structural performance of buried pipes. In the early 1900s, Marston load theory was developed for calculating the earth load on buried conduits (Marston, 1930). Later, a modified theory was developed for flexible pipe design which is a popular method (Spangler, 1941). In the past decade, with the improvements in digital computer performance combined with finite element techniques and sophisticated soil models, the methods for buried pipe design was improved to higher levels.

A pipe must have enough strength and/or stiffness to perform its intended function (Moser, 1990). It must also be durable enough to last for its design life. There are many different types of piping materials in the market today ranging from rigid concrete to flexible thermoplastic pipes such as HDPE (High Density Polyethylene) pipes, PVC (Polyvinyl Chloride) pipes, etc.(Moser, 1990). Characteristics such as inherent strength,

stiffness, corrosion resistance, abrasion resistance, lightness, flexibility and ease of joining are often regarded as reasons for using a particular material for pipe to perform its intended function.

Buried pipes fall into two categories: flexible pipe and rigid pipe. The American Water Works Association (AWWA) has classified types of pipe based on its deflection, as listed in the Table 1.1 (AWWA, 2002). 
Table 1.1: Pipe classification based on the percentage of deflection (AWWA, 2002)

\begin{tabular}{|c|c|}
\hline Pipe Classification & Percentage Deflection Before Damage \\
\hline RIGID & $0.1 \%$ \\
\hline SEMI-RIGID & $<3.0 \%$ \\
\hline FLEXIBLE & $>3.0 \%$ \\
\hline
\end{tabular}

Flexible pipes are again classified into two categories depending upon the materials with which they are manufactured. They are either plastic or metallic materials. Theses materials present very different mechanical characteristics. Metal pipes exhibit elastic properties while plastic pipes exhibit viscoelastic properties, where the influence of time is observed. The performance of High Density Polyethylene (HDPE) pipes is the main topic of interest in this research, which fall under the category of flexible pipes. Polyethylene pipes are available in several types and grades as per American Society of Testing and Materials (ASTM D-1248, 1998). Polyethylene pipes are characterized into Low-density polyethylene (LDPE) and High-density polyethylene (HDPE) on the basis of its density or volume mass. Table 1.2 below lists the design properties of polyethylene pipes.

Table 1.2: Polyethylene design properties (Moser, 1990)

\begin{tabular}{|c|c|}
\hline Hydrostatic-design basis (HDB) & $1250 \mathrm{lb} / \mathrm{in}^{2}$ \\
\hline Hydrostatic-design stress (HDS) & $625 \mathrm{lb} / \mathrm{in}^{2}$ \\
\hline Elastic modulus & $100,000 \mathrm{lb} / \mathrm{in}^{2}$ \\
\hline Tensile stress (Short-time) & $3200 \mathrm{lb} / \mathrm{in}^{2}$ \\
\hline Hazen-William coefficient (C) & 150 \\
\hline Manning's coefficient (n) & 0.009 \\
\hline
\end{tabular}

$1 \mathrm{psi}=6.89 \mathrm{kN} / \mathrm{m}^{2} ; 1 \mathrm{pcf}=16 \mathrm{~kg} / \mathrm{m}^{3} ; 1$ inch $=2.54 \mathrm{~cm}$.

High density polyethylene (HDPE) pipes have an ability to relax under stress (Moser, 1990; Goddard and Gabriel, 1998). When HDPE pipe is loaded, the pipe relaxes immediately, and over time, allows the load to be transferred to the adjacent soil. This characteristic enhances long-term structural performance of the pipe (Moser, 1990; 
Goddard and Gabriel, 1998). Therefore, HDPE pipes offer an excellent choice for gravity flow and low-head pipeline situations.

According to American Association of State Highway and Transportation Officials HDPE pipes are classified as (AASHTO M294, 2002; Plastic Pipe Institute, 2003):

- Type $\mathrm{C}$ - This pipe has a full circular cross section, with an annular corrugated surface both inside and outside.

- Type $\mathrm{S}$ - This pipe has a full circular cross section, with corrugated exterior surface and smooth interior surface.

- Type D - This pipe has a circular cross section, with a smooth inner wall joined to a smooth outer wall.

The research work presented in this report concentrates primarily on pipes with single wall circular cross section, with corrugated surface both inside and outside (Type C). Some background information on the nomenclature of buried pipes is given in Figure 1.1.

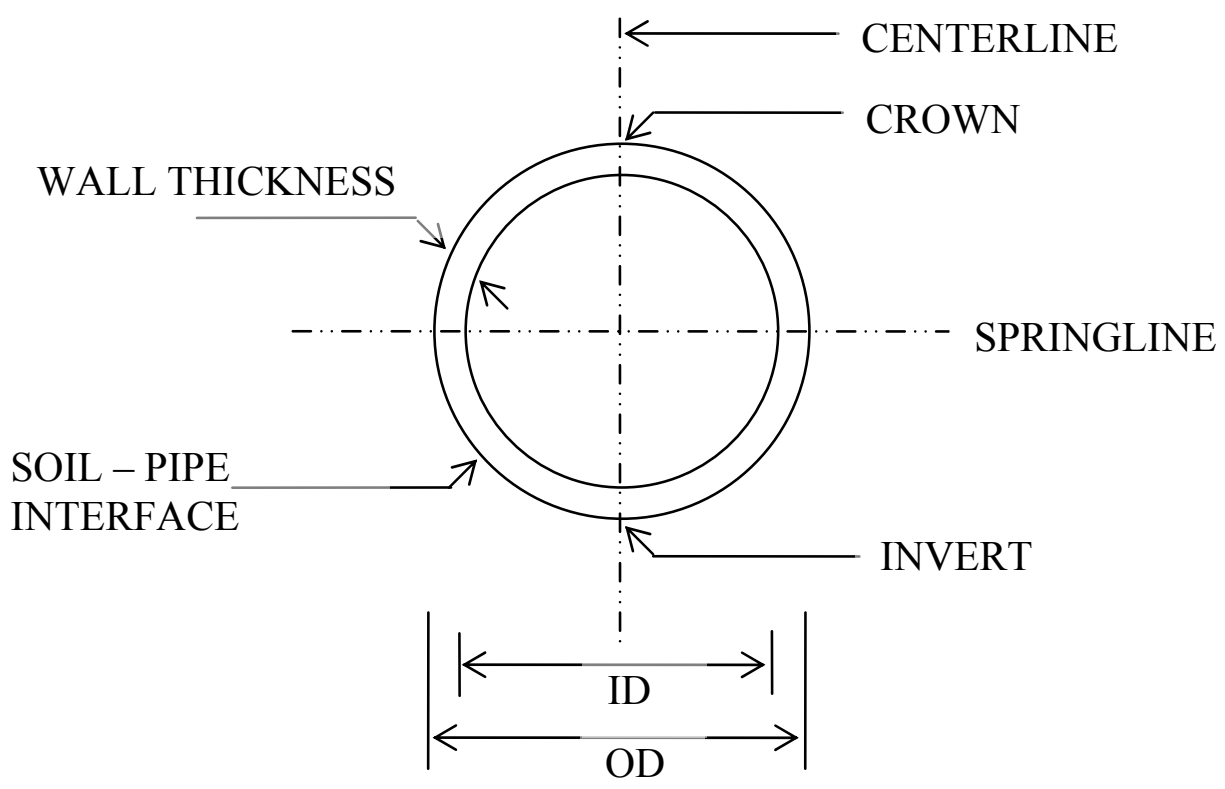

Note: ID $=$ Internal diameter

$\mathrm{OD}=$ Outside diameter

Figure 1.1: Pipe cross-section nomenclature 
Flexible pipes deflect under vertical load causing a decrease in vertical stress directly above the pipe and an increase in horizontal stress. This vertical stress decrease, known as arching, is caused by the deflection in the pipe which allows the soil mass above the pipe to slip downwards. The frictional forces between the in-situ soil and the backfill materials increase due to the slip caused by the backfill material. These frictional forces reduce some of the vertical stress on the pipe. The vertical force pushes the pipe outward towards the soil resulting an increase in horizontal stress. For a proper flexible pipe design, the characteristics of the in-situ soil and backfill material should be considered along with the bending characteristics of the pipe (Daniels, 1990).

The most general equation for computing horizontal pipe deflections has the following form (Spangler, 1941; Bulson, 1985).

$$
\Delta X=\frac{\text { Loading parameter }}{\text { Ring stiffness factor }+ \text { Soil stiffness factor }}
$$

The Equation 1.1 is known as Spangler's Iowa equation (Spangler, 1941; Bulson, 1985). It is also known as the fundamental static equation that governs the deflections in a ring. The magnitude of the horizontal deflections is $91.3 \%$ of the vertical deflections (Bulson, 1985). However, this ratio between the vertical and horizontal displacements was derived for an unsupported ring with diametrically opposite forces.

The ring stiffness factor is related to the bending characteristics of the pipe. Since many commercial flexible pipes are available with a wide range of strengths, the selection of the pipe will depend on anticipated loading conditions and the soil stiffness. It is clear from Equation 1.1 that if the loading conditions and the soil stiffness are known, a value for the maximum allowable deflection can be assumed to solve for the required pipe stiffness. By using the Spangler's Iowa equation, it has been stated that the deflections of a pipe can be reduced by 50 percent if Controlled Low Strength Materials (CLSM) was used rather than conventional backfill (Brewer, 1990). CLSM backfill can affect every stage of flexible pipe design, from vertical load estimation to selection of the pipe size and trench width requirements (Brewer, 1993). 


\subsection{Trench}

The emphasis of this study is on the interaction of flowable fill with buried pipes and the effect of trench width ratio $\left(\mathrm{N}_{\mathrm{r}}\right)$ on pipes performance. Some information regarding the trenches and their types is presented below. A trench is a relatively narrow ditch dug in undisturbed soil (Marston, 1913). Typical trench geometry for a compacted soil is shown in the Figure 1.2. The trenches filled with compacted earth are often wider to accommodate compaction equipment. Bedding is also placed under the pipe. Bedding is usually the compacted soil on which the buried pipe is placed. Bedding enhances the structural performance of buried pipes. Figure 1.3 shows trench geometry for controlled low strength materials (CLSM). The CLSM is poured around the entire pipe so that the sides are evenly and firmly supported. The top portion of the trench can either be filled with CLSM or compacted earth.

The width of the trench depends on the diameter of the pipe, type of native soil, the backfill material, the compaction method as well as the equipment used. The backfill area around the pipe should receive particular attention. 


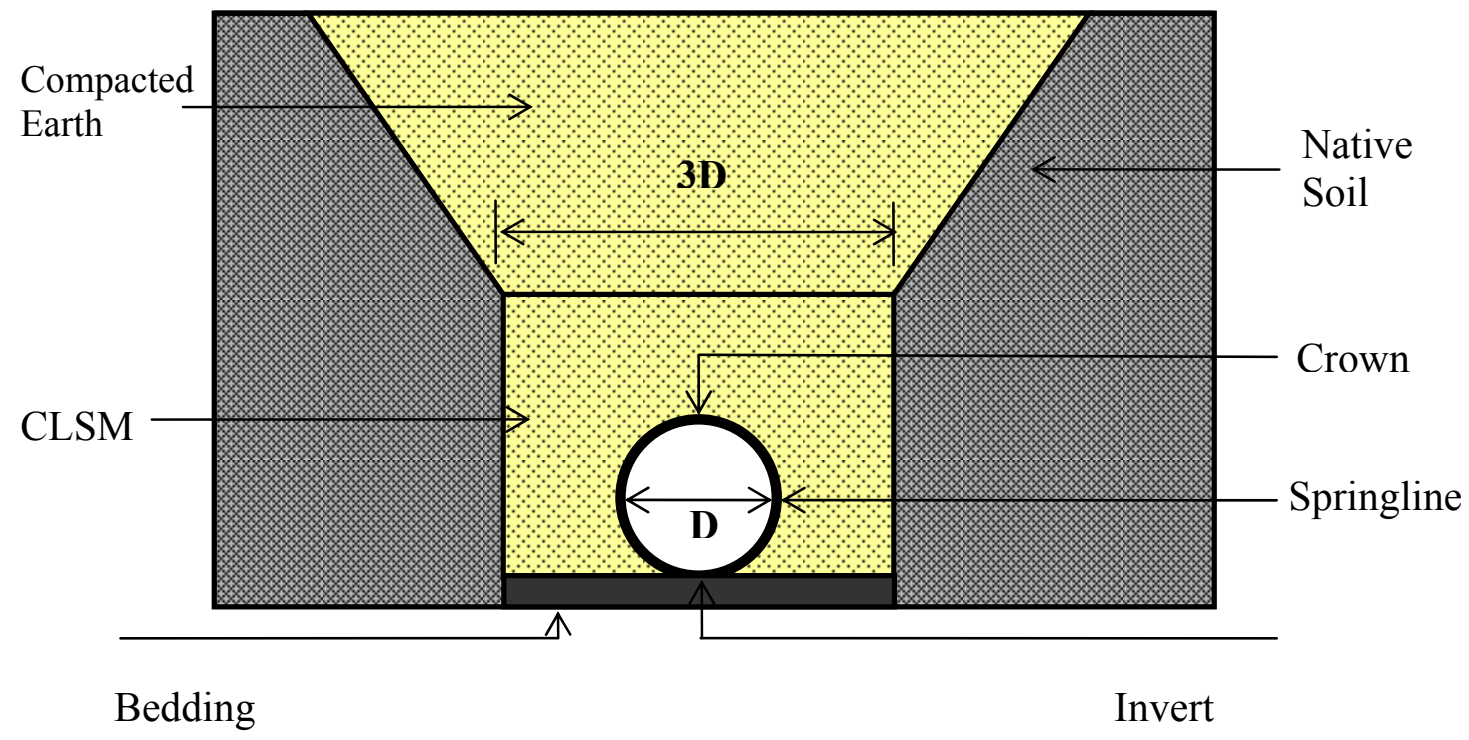

Figure 1.2: Typical trench geometry for compacted earth

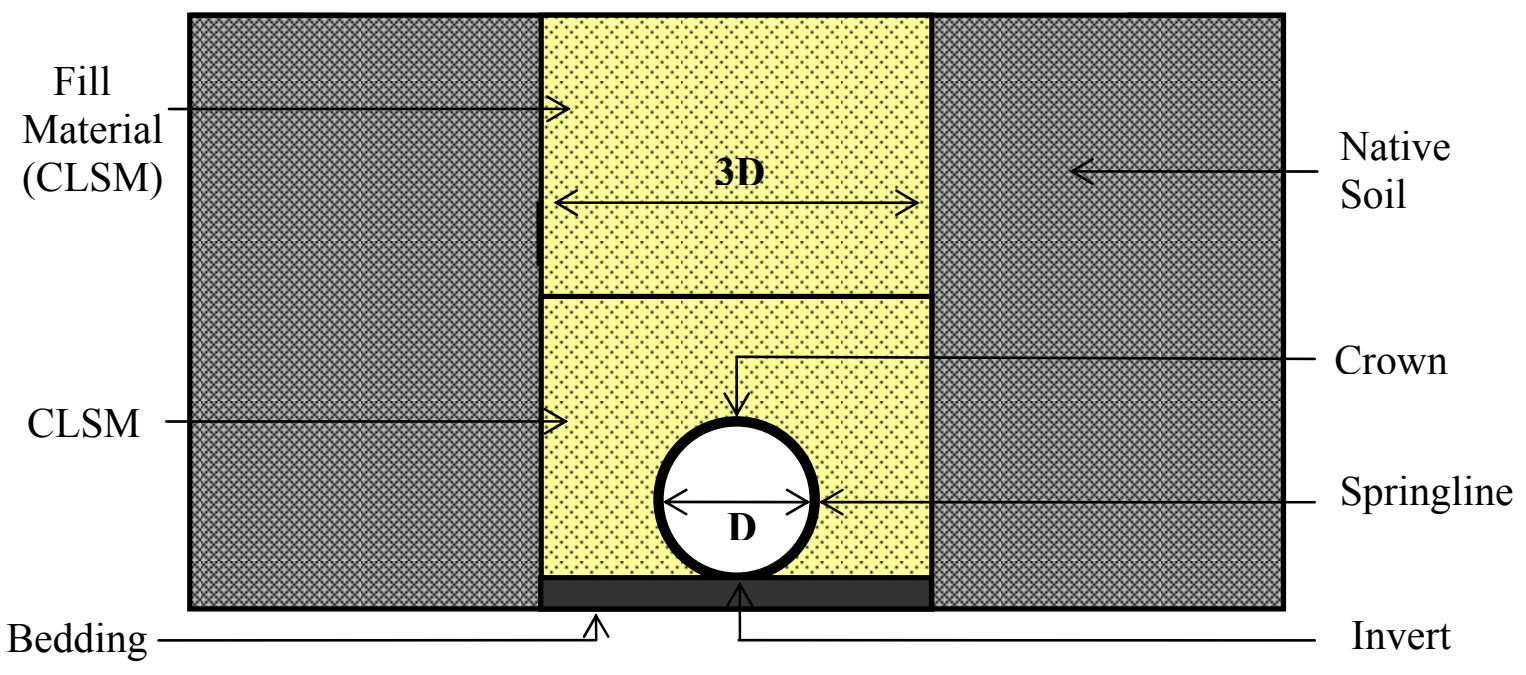

Note: $\mathrm{D}=$ Pipe diameter

$\mathrm{CLSM}=$ Controlled Low Strength Materials

Figure 1.3: Typical trench geometry for controlled low strength materials 


\subsection{Problem Statement:}

High Density Polyethylene pipes are major components for highway sewage systems. With the improvements in finite element techniques combined with powerful digital computers a comprehensive method to investigate long term structural performance of buried pipes can be developed.

Earlier study at the West Virginia University (Simmons, 2002) presented experimental results on the performance of HDPE pipes. However the experiments are limited to smaller diameter pipes under laboratory conditions. Present research extends the study to numerical analysis of large diameter buried pipes under the field conditions. The report also present the long term structural performance of HDPE pipes under greater depths.

Finite Element analysis was performed for single wall high density polyethylene (HDPE) pipes under laboratory and field conditions. Pipes with various diameters for different trench width ratios were considered. Vertical deflections were considered as the failure criteria for elevating the structural performance of buried pipes. Even though a 5 percent change in pipe diameter is commonly assumed as the failure condition for HDPE pipes as shown in Figure 1.4, in this report a limit of 4\% change was assumed as the pipe failure condition because of the potential damages caused during installation of pipes under field conditions.
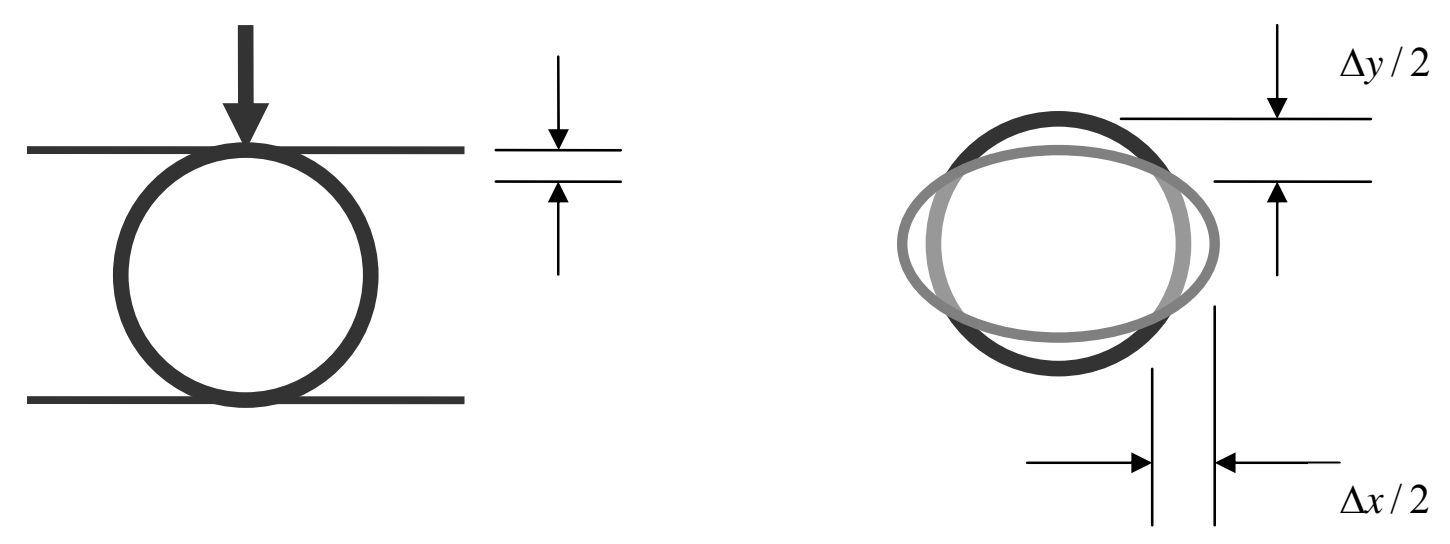

Figure 1.4: Pipe Deflections 


\subsection{Research Objectives:}

Primary objectives of the proposed research are listed below:

Investigate the performance of buried pipes using folwable materials as a backfill.

$>$ Investigate the influence of parameters that affect the structural performance of buried pipes. The parameters include:
a) Properties of native soil relative to the backfill
b) Pipe diameter
c) Pipe type (HDPE)
d) Pipe depth
e) Magnitude of external loads
f) Trench width

Specific objectives of the research are listed below:

$>$ Calculate the strength of the controlled low strength material (CLSM) mixtures, based on laboratory observations.

$>$ Develop finite element models for 6-inch $(15.3 \mathrm{~cm})$ and 8 -inch $(20.3 \mathrm{~cm})$ diameter HDPE pipes at different trench width ratios. Compare the numerical results obtained with that of the laboratory data.

> Develop finite element models for 18-inch $(45.7 \mathrm{~cm})$ and 24-inch $(61 \mathrm{~cm})$ HDPE pipes buried at varying depths $[D \geq 20 \mathrm{ft}(6.1 \mathrm{~m})]$ with different trench width ratios.

$>$ Analyze the structural performance of 18-inch $(45.7 \mathrm{~cm})$ and 24-inch $(61 \mathrm{~cm})$ HDPE pipes at different trench width ratios.

$>$ Evaluate the long-term structural performance of HDPE pipes up to 50 years.

$>$ Determine the minimum trench width ratio that can be used with CLSM mixtures.

Details of the research work are presented in the following chapters of this report. 


\section{CHAPTER 2 \\ LITERATURE REVIEW}

\subsection{Introduction}

High density polyethylene (HDPE) pipes have been used frequently for highway drainage due to its desirable characteristics for use as underground structures. HDPE pipes are relatively lightweight with only $0.95 \mathrm{grams} / \mathrm{cm}^{3}$ and weigh about one-fifth of steel pipes of the same size. HDPE pipes have the advantage of its ability to move or deflect under external loads without structural damage (Plastic Pipe Institute, 2003). HDPE pipes are structurally strong and have the ability to support large loads. Plastic pipes are made up of polymer materials. Plastic pipes are generally classified into thermoplastic pipes and thermosetting pipes. Thermoplastic pipes, which fall under the category of flexible plastic pipes, are most commonly subdivided into polyvinyl chloride (PVC) pipes and high density polyethylene (HDPE) pipes. Thermoplastic pipes are resistant to abrasion, corrosion and chemical scouring.

The major objective of this research is to investigate the structural performance of buried HDPE pipes. An extensive literature review of the structural performance of High Density Polyethylene (HDPE) pipes is presented in the following sections. The main aspects considered in the study are:

$>$ Structural response of HDPE pipes under laboratory conditions.

$>$ Structural response of HDPE pipes under field conditions.

Influence of soil types and CLSM mixtures on pipe performance.

\subsection{Structural response of HDPE pipes under laboratory conditions}

The structural response of small-diameter buried pipes subjected to large vertical pressures was investigated in the past (Brachman, 2000). The results obtained from the laboratory tests were compared to that of a finite element analysis to examine the effect of proximity and stiffness of the lateral boundary on the pipe response. It was found that the shear stresses arising from the roughness of the lateral boundaries alter the stress 
distribution around the pipe, which in turn reduces the applied surcharge load on the pipe. Outward deflection of the lateral boundaries alters the stress state around the pipe, which drastically decreases the horizontal stresses within the soil (Brachman, 2000).

Simplified equations to calculate deflections and circumferential strains in buried thermoplastic pipes were evaluated based on soil-structure interaction solutions (Dhar, 2002). These equations worked effectively for the HDPE and PVC pipes. The equations were further extended for calculating hoop and bending strains (Dhar, 2002).

A parallel plate loading tests on corrugated steel and High Density Polyethylene (HDPE) pipes were conducted to measure the local strain at the horizontal diameter of the pipe as shown in Figure 2.1 (Moore, 1994). Three dimensional finite element analyses were conducted to simulate laboratory test conditions. It was observed that the theoretical model yields the local strain at the horizontal diameter of the pipe within 5 to 15 percent of the measured values.

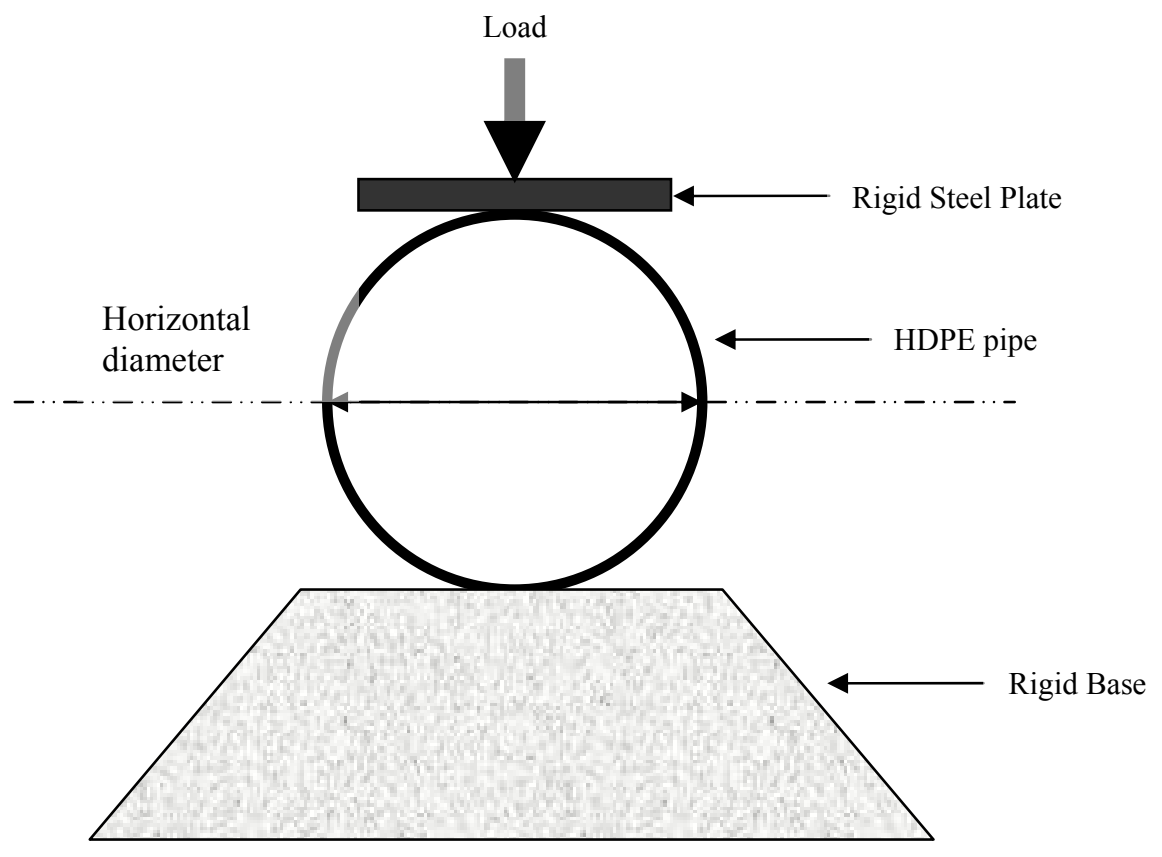

Figure 2.1: Parallel plate test apparatus 
At present, a variety of procedures are being used for the design of buried plastic pipes, depending on the pipe material and its applications. Plastic pipes are considered as flexible pipes (Moser, 1990). These flexible pipes can become elastically unstable due to buckling caused by external soil pressure (Moore, 1997). The local buckling in the corrugated wall of the polymer structures was investigated under increasing loads. Tests were also conducted on corrugated polyethylene pipes under axisymmetric hoop strain compression. The stiffened plate theory (Murray, 1975) provides a useful tool for predicting the local stability of profiled polyethylene pipes. It was concluded that the local soil support at the soil-pipe interface influences the buckling strength of buried flexible pipes.

The development of a new laboratory test to study the behavior of buried pipes under hoop compression loading has been reported in the literature (Selig, 1994). The apparatus consists of a cylindrical steel vessel lined with in an inflatable bladder where the pipe is installed at the center as shown in Figure 2.2. The space between the pipe and the bladder is filled with damped soil. The test is conducted by incrementally increasing the bladder pressure. This test has demonstrated significant circumferential shortening that occurs in corrugated plastic pipe sections. This test can be used to accurately determine the true wall compression limits.

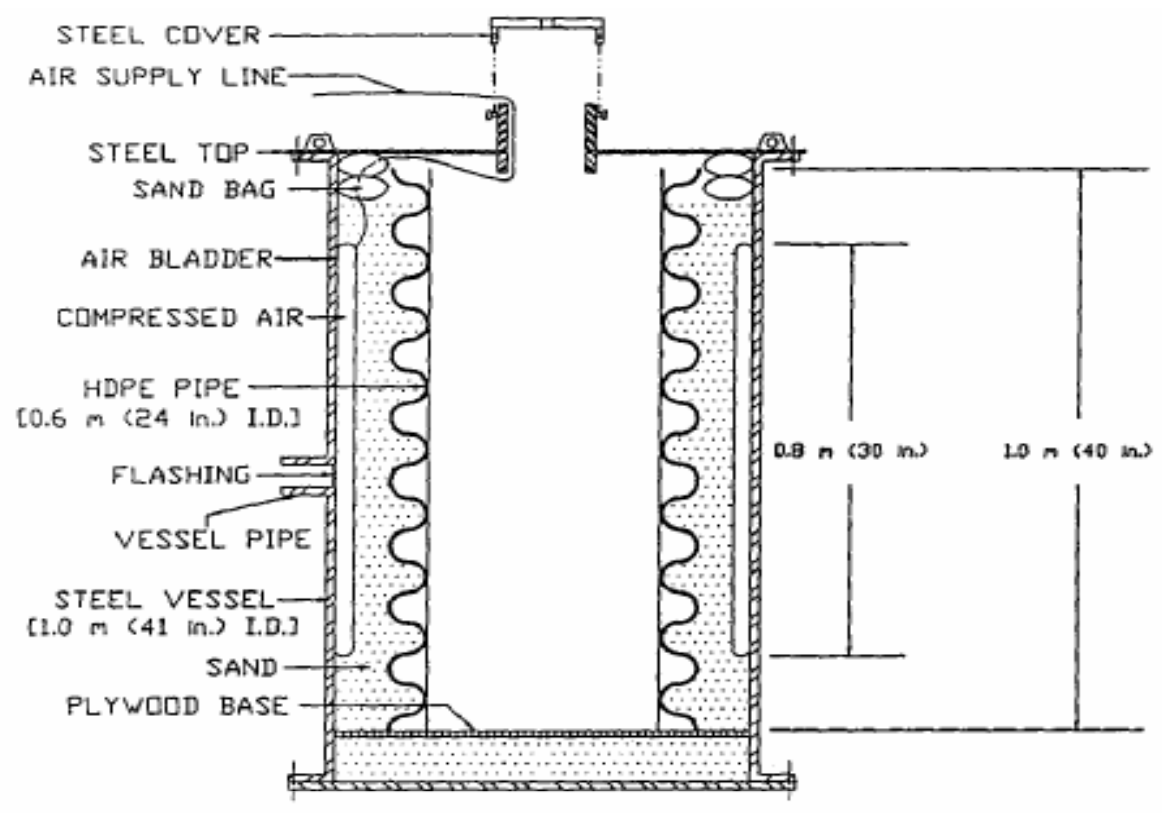

Figure 2.2: Cross section of pipe hoop compression test facility (Selig, 1994) 
A three-dimensional finite element analysis of a buried HDPE pipe was performed as reported in the literature (Moore and $\mathrm{Hu}, 1995)$. The numerical results were compared with laboratory tests in order to study the response of HDPE pipes under hoop compression. The schematic diagram of the test apparatus is shown in Figure 2.3. Distribution of circumferential and axial stresses and strains were considered in the numerical analysis. It was concluded that local bending occurs in the pipe liner, modifying the stress state in the pipe. The junction between the liner and the corrugation is subjected to largest axial tensions (Moore and $\mathrm{Hu}, 1995)$.

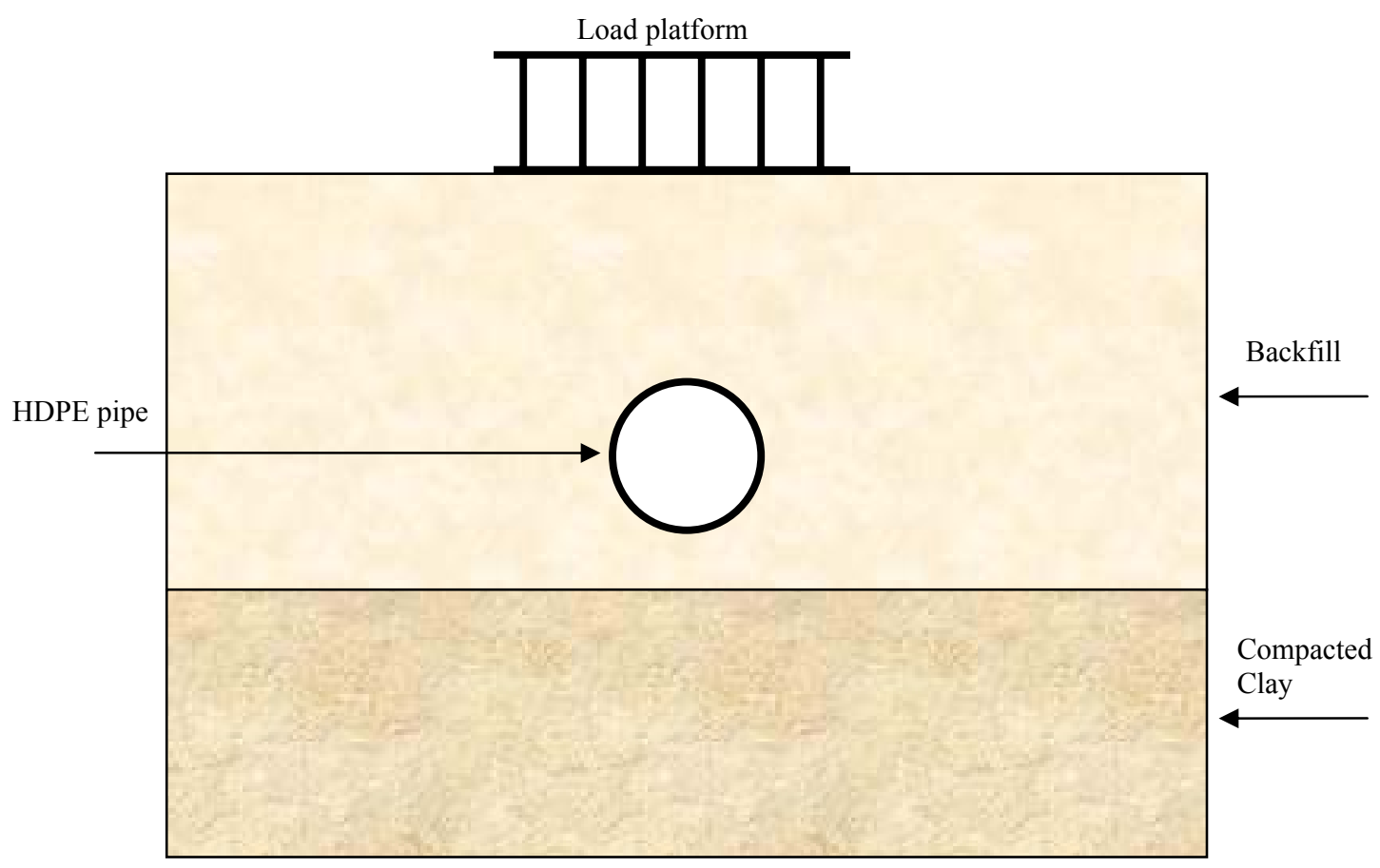

\section{Figure 2.3: Laboratory test setup to study the response of HDPE pipe under hoop compression}

HDPE materials exhibit a non-linear stress-strain behavior at working strain levels and time-dependent response at ambient temperature (Zhang, 1997). Experimental work to characterize the nonlinear time-dependent response of thick-walled HDPE pipes has been reported (Zhang, 1997). This study included numerous tests under constant strain rate, creep, stress relaxation, constant loading rate, and abrupt change of strain rate, creep recovery, cyclic strain rate and various combinations of these loadings. It was observed that 
under both loading and unloading conditions, stress-strain relations are highly nonlinear and dependent on strain and strain rate. In a similar study reported in the literature (Howard, 1972), permanent strains were observed in test specimens. The observed permanent strain was dependent on the loading history, maximum strain and the time during which material steadily deforms (Howard, 1972).

Influence of pipe wall geometry on the structural performance of buried HDPE pipes has been investigated experimentally (Moser, 1998). The pipe wall geometric parameters include rib height, rib spacing, wall thickness and cross sectional area per unit length of pipe. The area per unit length of a pipe is defined as the area of the cross section of the profile per unit length as shown in Figure 2.4 (a) and (b). It was observed that the cross-sectional area per unit length is the most significant parameter that resists the localized buckling.
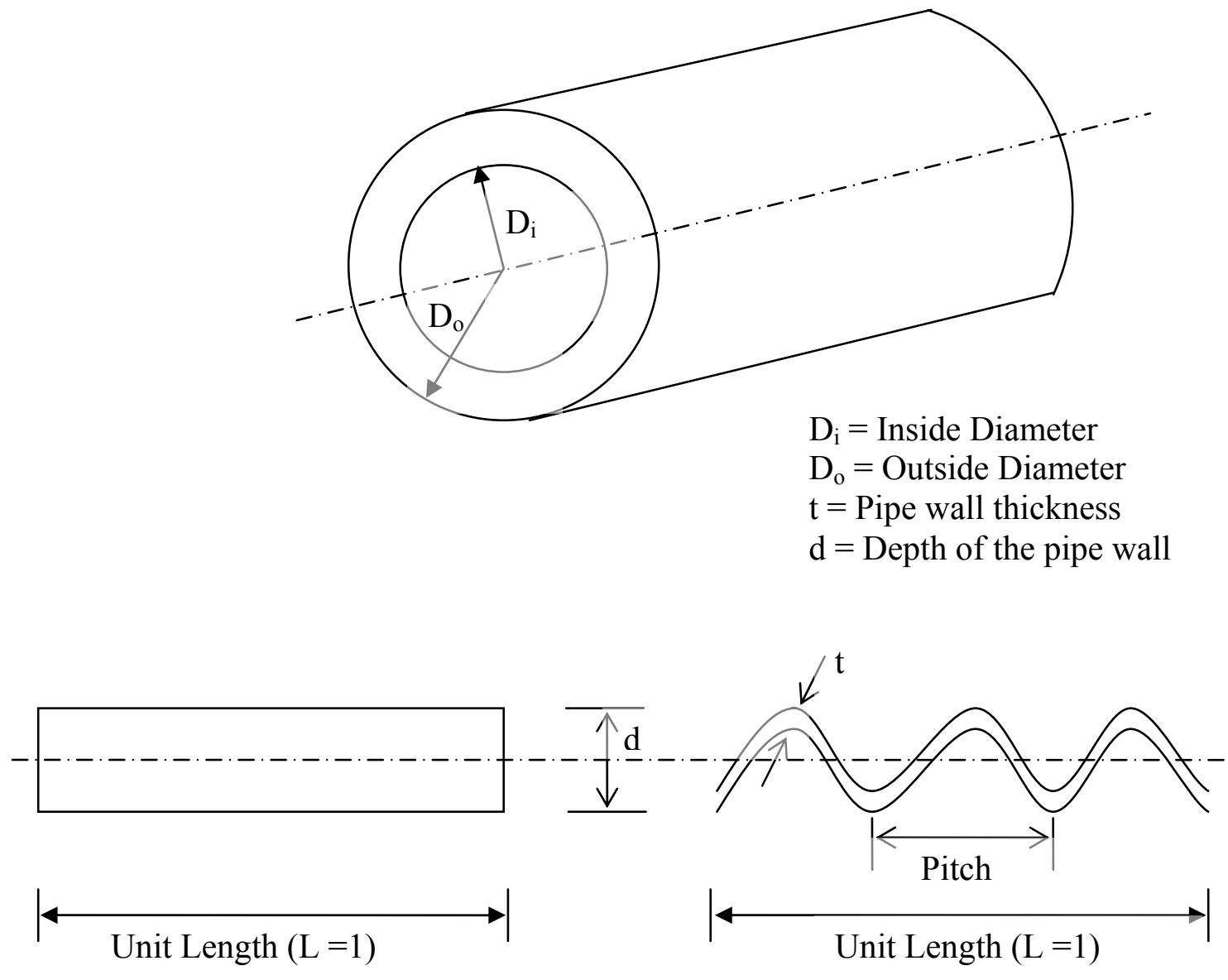

(a) Plain surface

(b) Corrugated surface

Figure 2.4: Buried pipe cross section 


\subsection{Structural response of HDPE pipes under field conditions}

In a different experimental study, the behavior of HDPE pipes with shallow cover was investigated (Phares, 1998). The study included a series of parallel plate loading tests and field tests on buried pipes under varying backfill conditions. Based on the results, it was concluded that the longitudinal strength of HDPE pipes should be considered in pipe design in addition to the circumferential strength and backfill properties. One of the significant observations in the study is that all the pipes under laboratory loading conditions failed approximately at the same longitudinal strain level. On the other hand, in field tests, pipes never reached the magnitude of strain associated with failure in the laboratory parallel plate tests. It has been found that the failure strain for laboratory tests is 7.5 to 10 times as that observed in field tests (Phares, 1998).

A research study was performed to evaluate the boundary effects on high density polyethylene (HDPE) pipes and low density polyethylene (LDPE) pipes under simulated live loads (Conard, 1998). Deflections of HDPE and LDPE pipes were measured under external loading. These tests were performed on $900 \mathrm{~mm}$ (36 in) and 1,200mm (48 in) diameter pipes using variety of backfills. It was found that the pipe deflections are slightly higher near the ends of the pipe than at the center when a load equivalent to highway tire pressure was applied. It was also concluded that the percentage deflections are not excessive and that the pipe-soil systems have adequate stiffness, except for Low-Density Polyethylene Pipes (LDPE). Experimental data has shown that the ultimate load carrying capacity of pipes with flowable fill as backfill is nearly twice as that of pipes with soil backfill (Conard, 1998).

A field study of an installation and performance of corrugated polyethylene pipes was reported (Fleckenstein, 1993) in the state of Kentucky. According to this study, the long term deflections do not appear to be a problem when pipes are properly installed. It was concluded that most of the pipe damages such as rips, delamination, and punctures were caused by improper construction procedures. The following procedures have been suggested for polyethylene pipes used in storm sewers and cross drains (Fleckenstein, 1993): 
"All polyethylene pipes should be installed according to ASTM 2321, with the addition of granular backfill."

$>$ "Granular backfill should be used to a minimum height of one foot above the crown of the pipe."

$>$ "Continued long-term inspection of all pipe installation should be implemented."

A research study to determine the field performance of smooth-lined HDPE pipes in Ohio is reported in the literature (Barna and White, 1998). This study has shown that the pipes performed adequately when installed using Ohio Department of Transportation design and installation guidelines.

The performance of deeply buried HDPE pipes have been examined experimentally as reported in the literature (Hashash and Selig, 1990). The field installation procedures and soil parameters during and after installation were considered in the experimental program. With a $100 \mathrm{ft}(30.5 \mathrm{~m})$ high soil cover, the measured soil compressive strain near the pipe was $1.7 \%$ and $4.2 \%$ at a distance of $16 \mathrm{ft}(4.9 \mathrm{~m})$ away from the pipe after a period of two years. Finite element method was also used to analyze the results obtained from field measurements. The analysis of viscoelastic nature of the pipe was approximated to a static analysis with reduced pipe modulus. The analysis was useful in estimating the hoop thrust in the pipe wall which could not be directly measured. The maximum computed compressive hoop stress was higher than the long term allowable limit. This increase in the hoop stress may be due to the use of design procedures that are based on tensile properties (Hashash, 1990).

One of the significant parameters for characterizing the flexibility of plastic pipes is its ring bending stiffness (Petroff, 1993). Ring bending stiffness is a measure of pipe's ability to resist deformation and is a key component of pipe deflection and buckling performance. Ring bending stiffness is a combination of material properties and pipe geometry. The affect of ring bending stiffness on the design of flexible pipes has been reported in the literature (Petroff, 1993). Some field measurements and laboratory data were presented to show the effect of ring bending stiffness on pipe deflection, local strain 
and buckling under external loads. It was concluded that the minimum acceptable pipe stiffness depends on the strain capacity of the pipe material and the pipe diameter.

In a different study (Sargand and Masada, 2000), the field performance of HDPE pipes with a nominal diameter of 42-inches $(107 \mathrm{~cm})$ subjected to a $52 \mathrm{ft}(15.85 \mathrm{~m})$ high soil fill for 1 year was monitored. It was observed that the horizontal deflections were stabilized within 40 days, but the vertical deflections took much longer time to stabilize. It was concluded that the vertical soil pressure measured at the crown and invert decreased slightly, while the lateral soil pressure measured at the spring line increased with time. The field performance of 60-inch $(152 \mathrm{~cm})$ diameter HDPE pipes subjected to $20 \mathrm{ft}(6.10 \mathrm{~m})$ and $40 \mathrm{ft}(12.20 \mathrm{~m})$ high embankment fills for about 2 years was evaluated as reported in the literature (Sargand and Masada, 2004). A significant conclusion drawn from the study was that the long-term performance of the HDPE pipes under constant soil fill loading is affected more by stress relaxation than by creep.

\subsection{Influence of soil types and CLSM mixtures}

The soil stiffness is one the most essential parameters in the design of buried pipes (Moser, 1990). Soil stiffness enhances the structural performance of buried pipes. The soil properties such as soil type, soil density and moisture content help to determine the necessary trench configuration and also to decide if an imported soil will be required as backfill around the pipe. The performance of HDPE pipes placed around sand with high compaction level and sand with nominal compaction levels were studied (Faragher, 1998). It was observed that for lightly compacted sand, soil stiffness (elastic modulus of soil) was found to be $16 \mathrm{MPa}$ and for thoroughly compacted sand, soil stiffness (elastic modulus of soil) was found to be $99 \mathrm{MPa}$. The highly compacted soil around the buried pipe significantly reduced the load transfer on to the pipe structure. It was concluded that the soil compaction level has a pertinent influence on the structural performance of buried pipes (Faragher, 1998).

Controlled Low Strength Materials - Controlled Density Fill (CLSM-CDF) as a backfill around flexible structures offer many advantages such as reduced construction 
costs, reduced excavation trench widths and reduced construction time (Brewer, 1993). The influence of CLSM-CDF on structural performance of HDPE pipes was studied in the literature (Brewer, 1993). The comparison of the pipe design parameters such as deflection lag factor $\left(\mathrm{D}_{\mathrm{L}}\right)$, modulus of soil reaction or strength of the soil $\left(E^{\prime}\right)$ bedding constant $(\mathrm{K})$ and Marston's load per unit length $\left(\mathrm{W}_{\mathrm{c}}\right)$ with soil as backfill and CLSM-CDF as backfill is listed in the Table 2.1. It was concluded that the external load on the pipe is reduced when CLSM-CDF is used as backfill. This reduction in external load helps in reduction of pipe deflection and enhances its structural performance (Brewer, 1993).

Table 2.1 Comparisons for soil and CLSM-CDF as backfill (Brewer, 1993)

\begin{tabular}{|c|c|c|}
\hline Variables & Soil as backfill & CLSM-CDF as backfil \\
\hline Deflection lag factor $\left(\mathrm{D}_{\mathrm{L}}\right)$ & 1.5 & 1.0 \\
\hline Bedding constant $(\mathrm{K})$ & 0.11 & 0.083 \\
\hline Marston's load per unit length $\left(\mathrm{W}_{\mathrm{c}}\right)(\mathrm{lb} / \mathrm{in}$ & $0.5-0.2$ & 0.2 \\
\hline Soil reaction $\left(E^{\prime}\right)\left(\mathrm{lb} / \mathrm{in}^{2}\right)$ & $200-3000$ & 1000 and above \\
\hline
\end{tabular}

Another field test was conducted on buried pipes with controlled low strength material (CLSM) as backfill (Webb, 1998). Prior to the field test, laboratory tests were conducted to determine the suitability of the component materials and to establish the proper mixture with acceptable flow characteristics. The field installation was in a trench with a width equal to the pipe outer diameter plus $600 \mathrm{~mm}$. The CLSM mixture was placed at the springline in two lifts, two hours apart. After 16 hours of CLSM placement, native soil was used as a backfill material above the CLSM mixture. The research work has shown that the CLSM provided excellent support for the pipe especially in areas that are hard to reach underneath the pipe. Following conclusions were made from the field test (Webb, 1998):

$>$ "The CLSM used in the test had good flow characteristics such that the delivery vehicle had to be placed only in two locations along the entire $8 \mathrm{~m}$ length of pipe backfilled with CLSM." 
"One of the major advantages of CLSM is its ability to reach areas underneath the pipe."

$>$ "Lower strengths of the CLSM mix may be needed to re-excavation of the pipe is necessary."

$>$ "Flow test was useful as quality control in the field before pouring the mixture into the trench."

In a different study, the use of controlled low strength material (CLSM) as pipe bedding has been investigated (McGrath and Hoopes, 1998). The influence of backfill material characteristics on pipe design parameters such as bedding factors and modulus of soil reaction $\left(E^{\prime}\right)$ was also investigated. Triaxial Compression and one-dimensional consolidation tests were conducted on two mixetures of air-modified CLSM to establish parameters for use in the finite element analyses of buried pipes. Tests were conducted at ages of 16 hours, 7 days and 28 days to evaluate the change in strength and stiffness with time. Duncan hyperbolic soil model (Duncan and Chang, 1970; Desai and Siriwardane, 1984) was used in the numerical analysis. It was concluded that the air-modified CLSM can be effectively used as a pipe backfill material. Although the strength and stiffness of air-modified CLSM increase with time, the standard backfill parameters indicate mobilization of good pipe support at an age as early as 16 hours after placing the material (McGrath and Hoopes, 1998).

\subsection{Scope of the research}

The above literature review summarizes the various parameters that affect the structural performance of high density polyethylene (HDPE) pipes under field and laboratory conditions. However, the influence of trench width on the performance of HDPE pipes is limited in the literature. This research emphasizes the influence of trench width on the long term structural performance of HDPE pipes with different CLSM mixtures as backfill material. The report also estimates the minimum safe trench width ratio $\left(\mathrm{N}_{\mathrm{r}}\right)$ that can be used with CLSM mixtures. The details of the research work are presented in this report. 


\section{CHAPTER 3}

\section{MATERIALS PROPERTIES}

\subsection{Soil properties}

The information on material properties used in the numerical analysis of this report is discussed in this section. The characteristics of the soil that surrounds the pipe structure are very important in the design of buried pipes. The soil properties such as soil type, soil density and moisture content help to determine the necessary trench configuration. Soil properties also help in deciding whether an imported soil will be required as backfill around the pipe. These soil properties are usually determined from laboratory tests.

Soil not only acts as a material upon which the structure rests, but also acts as a material that helps to reduce the external loads applied onto the buried structure. The surrounding soil transfers surface and gravity loads to and from the buried structure. The American Association of State Highway and Transportation Officials (AASHTO, 2000) and the American Society for Testing and Materials (ASTM 4832, 2000) issued standard test methods for determination of various soil properties. Soils can be classified broadly into four groups (Moser, 1990).

> Gravel: Consists of individual grains varying from 0.08 to 3 inches in diameter.

$>$ Sand: Consists of individual rock fragments with less than 0.08 inch in diameter.

$>$ Silt: Consists of fine grains which are soft and floury.

$>$ Clay: Consists of fine texture soil which forms hard lumps when dry and sticky when wet.

Failure of buried pipes is generally associated with failure of the soil in which the pipe structure is buried. This failure or collapse of a soil occurs when the soil reaches its shear strength. 


\subsubsection{Shear strength of soil}

The shear strength of a soil is defined as the intensity of force at which the soil crushes or fails. The shear strength $(\tau)$ of a soil is given by the Mohr-Coulomb failure criteria which is given below.

$$
\tau=c+(\sigma-u)(\tan \varphi)
$$

Where, $\tau=$ shearing strength of a soil $(\mathrm{kPa})$.

$$
\begin{aligned}
& \sigma=\text { total normal stress }(\mathrm{kPa}) . \\
& \varphi=\text { angle of friction (degrees). } \\
& \mathrm{c}=\text { cohesion }(\mathrm{kPa}) . \\
& u=\text { pore water pressure }(\mathrm{kPa}) .
\end{aligned}
$$

For drained soil $u=0$. For a failure analysis, it is necessary to determine the angle of friction $(\varphi)$ and cohesion (c) of the soil. One method to determine the shear strength of a soil is to perform triaxial compression tests on a given soil mass. Mohr circle plotted on the basis of the experimental data helps determine the shear and normal stresses at a given point in the soil mass. A typical Mohr circle to determine the stresses at a point on a given plane of a soil cube is shown in Figure 3.1. The equations for the magnitude of shear and normal stresses are given below (Watkins, 1999).

$$
\begin{aligned}
& \tau=\left(\frac{\sigma_{1}-\sigma_{3}}{2}\right) \sin 2 \alpha \\
& \sigma=\left(\frac{\sigma_{1}+\sigma_{3}}{2}\right)+\left(\frac{\sigma_{1}-\sigma_{3}}{2}\right) \cos 2 \alpha
\end{aligned}
$$




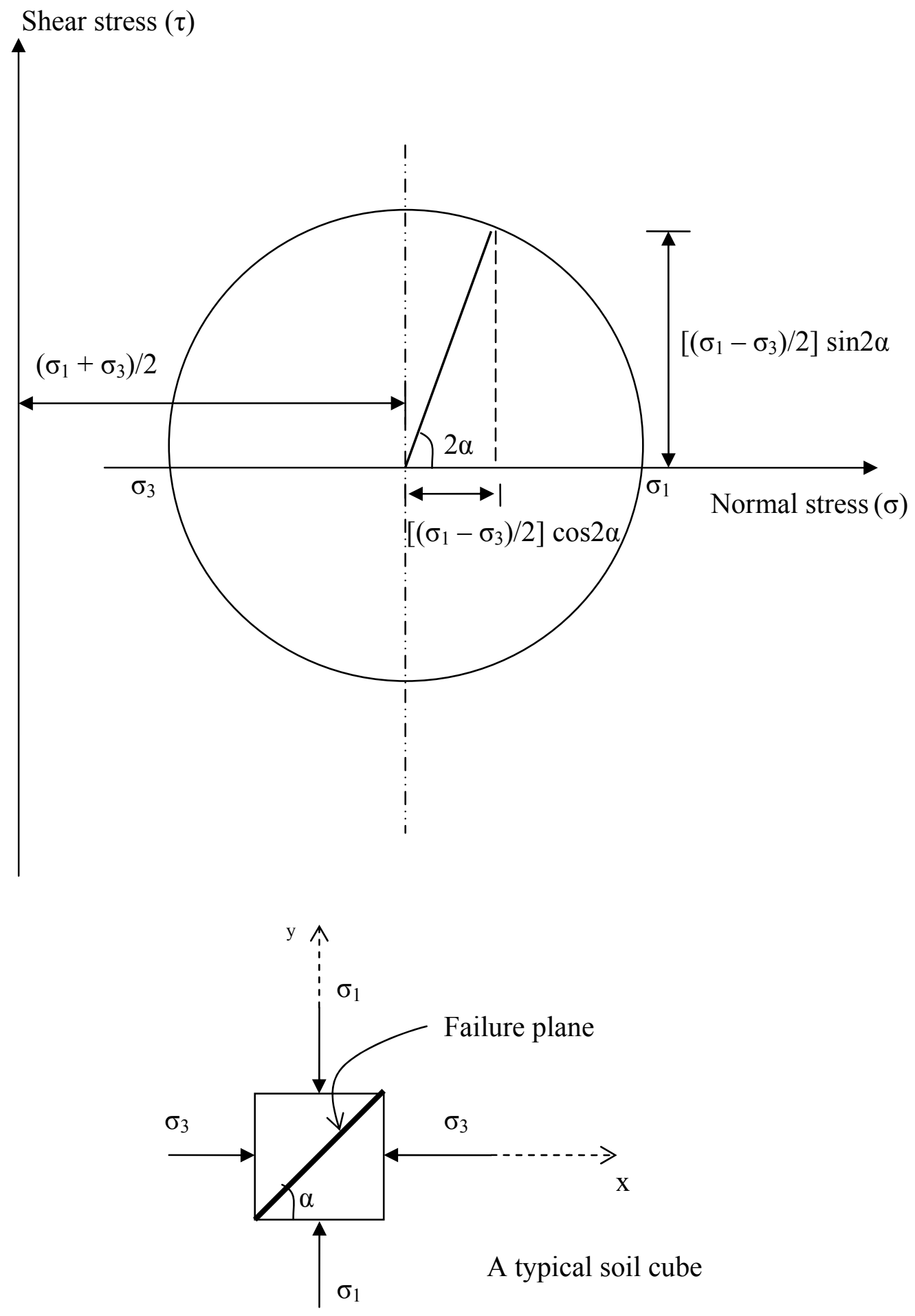

Figure 3.1: Mohr circle for stress 
A convenient way of expressing the stiffness of a soil is the degree of compaction as laid out in the American Society of Testing and Materials specification (ASTM 698, 2000). The soil modulus is also known as soil stiffness which is widely used by pipe design engineers as given in Table 3.1 (Moser, 1990). The soil properties used in the finite element analysis presented in this report are given in Table 3.2.

\subsection{Backfill materials}

The deflection and structural performance of buried pipes mainly depend on the compressibility of the soil. The soil type, soil density, moisture content and stiffness play an important role in successful installation of a buried pipe (Moser, 1990). An imported soil (backfill material) is required in most cases to place around the pipe for additional stiffness. The selection of backfill material involves consideration of factors such as depth of cover, depth of water table, pipe materials and compaction of backfill material (Moser, 1990).

Flowable fill is a controlled low-strength material that consists of aggregates and/or fly ash, portland cement and water that provide unconfined compressive strengths ranging from 50 psi to 1200 psi (Simmons, 2002). This relatively new material is becoming increasingly popular in engineering applications. Most departments of transportation have included flowable fill as a backfill material in their specifications. The West Virginia department of Transportation (WVDOT) gives the following specifications for an approved class C fly ash (WVDOH, 2000):

> Amount retained on \# 325 sieve must be less than 34\%.

Loss on ignition must be less than $6 \%$.

$>\left(\mathrm{SiO}_{2}+\mathrm{AlO}_{3}+\mathrm{Fe}_{2} \mathrm{O}_{3}\right)$ must be greater than $50 \%$.

Flowable fill materials have the ability to self level, exhibit good flow characteristic and are not subjected to segregation. The main characteristics are its hardening properties, flowability and final strength. Flowable fill provides an opportunity to use waste materials, which may result in an economical mix. Moreover, it helps in diversion of a waste material from landfills to a beneficial use that provides an environmental benefit. 
Table 3.1: Typical Modulus for Soil (Moser, 1990)

\begin{tabular}{|c|c|c|c|c|c|c|c|c|c|c|}
\hline \multirow{3}{*}{ SOIL TYPE } & \multicolumn{8}{|c|}{ Young's Modulus (psi) } & \multirow{3}{*}{$\begin{array}{c}\text { Poisson's } \\
\text { Ratio }\end{array}$} & \multirow{3}{*}{$\begin{array}{c}\text { Unit } \\
\text { Weight } \\
\text { (pcf) }\end{array}$} \\
\hline & \multicolumn{8}{|c|}{ Confining pressure } & & \\
\hline & 5 psi & 10 psi & 15 psi & 20 psi & 25 psi & 30 psi & 35 psi & 40 psi & & \\
\hline $\begin{array}{l}\text { Granular } \\
\text { Fair Compaction } \\
\text { Good Compaction }\end{array}$ & $\begin{array}{c}550 \\
1100\end{array}$ & $\begin{array}{c}750 \\
1300\end{array}$ & $\begin{array}{c}850 \\
1500\end{array}$ & $\begin{array}{l}1000 \\
1650\end{array}$ & $\begin{array}{l}1100 \\
1800\end{array}$ & $\begin{array}{l}1150 \\
1900\end{array}$ & $\begin{array}{l}1300 \\
2100\end{array}$ & $\begin{array}{l}1400 \\
2250\end{array}$ & $0.3-0.35$ & $110-150$ \\
\hline $\begin{array}{l}\text { Mixed } \\
\text { Fair Compaction } \\
\text { Good Compaction }\end{array}$ & $\begin{array}{l}400 \\
600\end{array}$ & $\begin{array}{l}550 \\
850\end{array}$ & $\begin{array}{c}600 \\
1100\end{array}$ & $\begin{array}{c}700 \\
1100\end{array}$ & $\begin{array}{c}750 \\
1200\end{array}$ & $\begin{array}{c}800 \\
1250\end{array}$ & $\begin{array}{c}900 \\
1350\end{array}$ & $\begin{array}{c}900 \\
1450\end{array}$ & $0.3-0.4$ & $100-140$ \\
\hline $\begin{array}{l}\text { Cohesive } \\
\text { Fair Compaction } \\
\text { Good Compaction }\end{array}$ & $\begin{array}{l}150 \\
250\end{array}$ & $\begin{array}{l}200 \\
325\end{array}$ & $\begin{array}{l}225 \\
373\end{array}$ & $\begin{array}{l}250 \\
375\end{array}$ & $\begin{array}{l}250 \\
400\end{array}$ & $\begin{array}{l}250 \\
400\end{array}$ & $\begin{array}{l}250 \\
400\end{array}$ & $\begin{array}{l}250 \\
400\end{array}$ & $0.35-0.4$ & $100-130$ \\
\hline
\end{tabular}

$1 \mathrm{psi}=6.89 \mathrm{kN} / \mathrm{m}^{2} ; 1 \mathrm{pcf}=16 \mathrm{~kg} / \mathrm{m}^{3} ; 1 \mathrm{inch}=2.54 \mathrm{~cm}$. 
Table 3.2: Material properties for cohesive and loose in-situ soil

\begin{tabular}{|l|c|c|c|c|c|c|}
\hline \multirow{2}{*}{ Parameters } & \multicolumn{3}{|c|}{ Cohesive In-Situ Soil } & \multicolumn{3}{c|}{ Loose In-Situ Soil } \\
\cline { 2 - 7 } & \multicolumn{2}{|c|}{ Trench width ratio } & \multicolumn{3}{c|}{ Trench width ratio } \\
\cline { 2 - 7 } & $\mathbf{1 . 5}$ & $\mathbf{2}$ & $\mathbf{2 . 5}$ & $\mathbf{1 . 5}$ & $\mathbf{2}$ & $\mathbf{2 . 5}$ \\
\hline Young's modulus (E) psi & 1000 & 2000 & 2000 & 400 & 600 & 1500 \\
\hline Poisson's ratio (v) & 0.3 & 0.3 & 0.3 & 0.3 & 0.3 & 0.3 \\
\hline Mass density $(\rho)^{* * *}$ pcf & 100 & 100 & 100 & 100 & 100 & 100 \\
\hline
\end{tabular}

** Reference (ASTM D2487) $1 \mathrm{psi}=6.89 \mathrm{kN} / \mathrm{m}^{2} ; 1 \mathrm{pcf}=16 \mathrm{~kg} / \mathrm{m}^{3} ; 1 \mathrm{inch}=2.54 \mathrm{~cm}$.

For backfilling around flexible structures, the compressive strength should be in the range of 100 psi (Simmons, 2002). The use of Controlled Low Strength Material (CLSM) eliminates majority of backfill concerns on conventionally placed backfills. Some of the significant concerns that CLSM eliminates are:

- Non-uniform side support of the structure

- Changes in soil moisture levels

- Soil composition

- Soil density

- Improper installation

- Surface settlement

- Joint leakage

- External corrosion

These concerns are eliminated because the CLSM mixture is designed in the laboratory for consistency and easy placement around a flexible structure. The placement of CLSM material around the buried structure requires no labor, other than directing it through a nozzle.

\subsubsection{Material Design}

The main components for CLSM are portland cement, fine aggregate, fly ash and water. The component mixture can be varied depending upon the required stiffness and its application. Any adjustments of the components require testing prior to field use to 
ensure that the end result requirements are met. The there major properties that the CLSM must posses are: flowability, strength and competitive price.

\subsubsection{Portland Cement}

Type I portland cement (ASTM C150, 2002) is generally used with CLSM mixtures. The amount of Portland cement used in the mixture is in the range of $3 \%$ of the overall weight. The main purpose of the portland cement in CLSM mixture is to provide cohesion and strength control.

\subsubsection{Fine Aggregate}

Major portion (72\%) of a typical CLSM mixture contains fine aggregates known as filler. The filler should posses adequate gradation similar to the requirements set in ASTM C33 to ensure proper flowability. The two major aggregates used in this research were tested in an earlier study conducted at West Virginia University (Simmons, 2002). The first is the bottom ash from Morgantown Energy Associates (MEA), and the second is the Ohio River sand commercially available in Morgantown, West Virginia. The dry unit weights of these three aggregates are measured as follows:

$$
\begin{aligned}
& \text { Bottom Ash }=82.8 \mathrm{lb} / \mathrm{ft}^{3}\left(13.0 \mathrm{kN} / \mathrm{m}^{3}\right) \\
& \text { River Sand }=99.2 \mathrm{lb} / \mathrm{ft}^{3}\left(15.6 \mathrm{kN} / \mathrm{m}^{3}\right) \text {. } \\
& \text { Foundry Sand }=94.4 \mathrm{lb} / \mathrm{ft}^{3}\left(14.8 \mathrm{kN} / \mathrm{m}^{3}\right) \text {. }
\end{aligned}
$$

The grain size distribution of each material was also measured and reported elsewhere (Simmons, 2002).

\subsubsection{Fly Ash}

Fly ash can make up to $90 \%$ of the total CLSM mixture (Simmons, 2002). The fly ash used for the experiments conducted in the earlier study was obtained from Morgantown Energy Associates (MEA) in Morgantown, West Virginia. The average loss on ignition is $2 \%$ for the fly ash and $1 \%$ for the bottom ash (Simmons, 2002). A sieve analysis conducted in the experimental work (Simmons, 2002) showed that $85 \%$ passed the \#325 sieve. The dry unit weight, specific gravity, and water content were also measured (Simmons, 2002). These properties are given below. 
Dry unit weight, $\gamma_{\text {dry }}=42.9 \mathrm{lb} / \mathrm{ft}^{3}\left(6.7 \mathrm{KN} / \mathrm{m}^{3}\right)$

$>$ Specific gravity, $\mathrm{G}=2.78$

Water content, $\mathrm{w}=0.13 \%$

A backfill material with high stiffness helps in reducing the compressive pressure acting on the buried pipe, which enhances the long term structural performance of the pipe. One of the major advantages of the backfill material is its availability at different strengths, which can be obtained by method of compaction. The backfill properties used in the finite element analysis presented in this report are given in Table 3.3. These values were back calculated from the laboratory experimental data as shown in Appendix C. Table 3.4 lists the classes and types of bedding material used for backfill material in the United States. Table 3.5 presents the estimated range of degree of compaction of different classes of bedding material.

Table 3.6 presents typical values of soil reaction modulus based on empirical methods (ASTM D2321, 1995; ASTM D2487, 2000). Soil reaction modulus ( $\left.E^{\prime}\right)$ is defined as an empirical value used to express the stiffness of the embedment soil in predicting flexible pipe deflection. Soil reaction modulus has also been referred to as the soil modulus or the soil stiffness (Moser, 1990).

Table 3.3: Material properties for high strength and low strength backfill

\begin{tabular}{|c|c|c|c|c|c|c|}
\hline \multirow{2}{*}{ Parameters } & \multicolumn{3}{|c|}{ High strength backfill } & \multicolumn{3}{c|}{ Low strength backfill } \\
\cline { 2 - 7 } & \multicolumn{3}{|c|}{ Trench width ratio } & \multicolumn{3}{c|}{ Trench width ratio } \\
\cline { 2 - 7 } & $\mathbf{1 . 5}$ & $\mathbf{2}$ & $\mathbf{2 . 5}$ & $\mathbf{1 . 5}$ & $\mathbf{2}$ & $\mathbf{2 . 5}$ \\
\hline Young's modulus (E) psi & 1000 & 3000 & 6200 & 400 & 1700 & 2250 \\
\hline Poisson's ratio (v) & 0.3 & 0.3 & 0.3 & 0.3 & 0.3 & 0.3 \\
\hline Mass density $(\boldsymbol{\rho})^{* * *}$ pef & 150 & 150 & 150 & 150 & 150 & 150 \\
\hline
\end{tabular}

** Reference (ASTM D2487) $1 \mathrm{psi}=6.89 \mathrm{kN} / \mathrm{m}^{2} ; 1 \mathrm{pcf}=16 \mathrm{~kg} / \mathrm{m}^{3} ; 1 \mathrm{inch}=2.54 \mathrm{~cm}$. 
Table 3.4: Types of bedding materials used for backfill material (ASTM D2321, 1995).

\begin{tabular}{|c|c|c|}
\hline \multicolumn{3}{|r|}{ Classification of Backfill Components } \\
\hline Class & Type & Description of Backfill Class \\
\hline \multirow{2}{*}{$\begin{array}{l}\mathrm{IA}^{*} \\
\mathrm{IB}^{*}\end{array}$} & --- & $\begin{array}{l}\text { Granular material: angular crushed stone or rock, crushed gravel, crushed slag, large voids, } 6 \\
\text { to } 40 \mathrm{~mm} \text { ( } 1 / 4 \text { to } 1 \frac{1 / 2}{2} \text { inches) with little or no fines. }\end{array}$ \\
\hline & --- & $\begin{array}{l}\text { Angular crushed stone or other class 1A material with or without other regional components } \\
\text { such as coral, ash, crushed stone, shell and stone/sand mixture, with little or no fines. }\end{array}$ \\
\hline \multirow[t]{4}{*}{ II $^{*}$} & GW & $\begin{array}{l}\text { Well-graded gravel of } 40 \mathrm{~mm}\left(1 \frac{1}{2} \text { inches }\right) \text { maximum and mixture of sand and gravel, little or } \\
\text { no fines. } 50 \% \text { or more of gross retained by } \# 4 \text { sifter. More than } 95 \% \text { retained by } \# 200 \text { sifter. } \\
\text { Clean. }\end{array}$ \\
\hline & GP & $\begin{array}{l}\text { Poorly graded gravel, gravel } / \text { sand mixtures, little or no fines. } 50 \% \text { or more of gross retained } \\
\text { by } \# 4 \text { sifter. More than } 95 \% \text { retained by } \# 200 \text { sifter. Clean. }\end{array}$ \\
\hline & SW & $\begin{array}{l}\text { Well-graded sands, gravel sand; little or no fines. } 50 \% \text { or more of gross retained by } \# 4 \text { sifter. } \\
\text { More than } 95 \% \text { retained by } \# 200 \text { sifter. Clean. }\end{array}$ \\
\hline & SP & $\begin{array}{l}\text { Poorly graded gravel, gravelly sands, little or no fines. } 50 \% \text { or more of gross retained by } \# 4 \\
\text { sifter. More than } 95 \% \text { retained by } \# 200 \text { sifter. Clean. }\end{array}$ \\
\hline \multirow[t]{4}{*}{ III $^{*}$} & GM & $\begin{array}{l}\text { Silty gravels, gravel } / \text { sand } / \text { slit mixtures More than } 50 \% \text { passes through } \# 4 \text { sifter. More than } \\
50 \% \text { retained by } \# 200 \text { sifter. }\end{array}$ \\
\hline & GC & $\begin{array}{l}\text { Clayish sands, gravel/sand/clay mixtures More than } 50 \% \text { passes through } \# 4 \text { sifter. More than } \\
50 \% \text { retained by } \# 200 \text { sifter. }\end{array}$ \\
\hline & SM & $\begin{array}{l}\text { Silty sands, sand/slit mixtures. More than } 50 \% \text { passes through } \# 4 \text { sifter. More than } \\
50 \% \text { retained by } \# 200 \text { sifter. }\end{array}$ \\
\hline & $\mathrm{SC}$ & $\begin{array}{l}\text { Clayish sands, sand/clay mixtures More than } 50 \% \text { passes through } \# 4 \text { sifter. More than } \\
50 \% \text { retained by } \# 200 \text { sifter. }\end{array}$ \\
\hline \multirow[t]{2}{*}{$\operatorname{IVA}^{* * *}$} & ML & $\begin{array}{l}\text { Inorganic silts and very fine sands, rock flour silty or clayish fine sands, silts with slight } \\
\text { plasticity, sand with average to high flow and liquidity limit. Limit of } 50 \% \text { or less liquid. } \\
\text { More than } 50 \% \text { passes through \#200 sifter. }\end{array}$ \\
\hline & CL & $\begin{array}{l}\text { Inorganic clays of low to moderate plasticity, gravelly, sandy or silty clays, lean clays, sand } \\
\text { with moderate to high flow and liquidity limit. Limit of } 50 \% \text { or less liquid. More than } 50 \% \\
\text { passes through } \# 200 \text { sifter. }\end{array}$ \\
\hline \multirow[t]{2}{*}{$\mathrm{IVB}^{* * *}$} & $\mathrm{MH}$ & $\begin{array}{l}\text { Inorganic silts,macaceous or diamaceous fine sandy, or silty soils,elstic soils with moderate to } \\
\text { high flow and liquidity limit. Limit of } 50 \% \text { or less liquid. More than } 50 \% \text { passes through } \\
\# 200 \text { sifter. }\end{array}$ \\
\hline & $\mathrm{CH}$ & $\begin{array}{l}\text { Inorganic clays of high plasticity with moderate to high flow and liquidity limit. Limit of } 50 \% \\
\text { or less liquid. More than } 50 \% \text { passes through } \# 200 \text { sifter. }\end{array}$ \\
\hline \multirow[t]{3}{*}{$V^{* * * *}$} & OL & $\begin{array}{l}\text { Organic slits and organic silty clays with low plasticity. Limit of } 50 \% \text { or less liquid. More } \\
\text { than } 50 \% \text { passes through } \# 200 \text { sifter. }\end{array}$ \\
\hline & $\mathrm{OH}$ & $\begin{array}{l}\text { Organic clays of moderate to high plasticity, organic silts. Limit of } 50 \% \text { or less liquid. More } \\
\text { than } 50 \% \text { passes through } \# 200 \text { sifter. }\end{array}$ \\
\hline & PT & Peat, manure and other highly organic soils. \\
\hline
\end{tabular}

* As described in standard ASTM D 2487, with the exception of Classe I materials which are described in the ASTM D2321 standard.

** According to standard ASTM D2487, less than $5 \%$ of soils pass through \#200 stifter.

${ }^{* * *}$ According to standard ASTM D2487, 5 to $12 \%$ of soils that pass through \#200 sifter fall within the limits of the classification which is more characteristic of class II than class III. Soils of types MH, ML, CH and CL are not recommended for the bedding, the haunch or the initial backfill.

${ }^{* * * *}$ This class includes frozen soil, debris and rocks bigger than 40mm (1 1 1/2 inches) in size. All materials OL, OH and PT are not recommended for the bedding, the haunch or the initial backfill. 
Table 3.5: Degree of compaction of backfill materials (CAN/CSA B182.11, 2004)

\begin{tabular}{|c|c|c|c|c|}
\hline \multicolumn{5}{|c|}{ Compaction of Backfill Materials } \\
\hline Class of material & I & II & III & IV \\
\hline $\begin{array}{l}\text { Description of } \\
\text { material }\end{array}$ & $\begin{array}{c}\text { Angular } \\
\text { manufacturing } \\
\text { stones }\end{array}$ & $\begin{array}{l}\text { Gravel and } \\
\text { sand without } \\
\text { fines, clean }\end{array}$ & $\begin{array}{l}\text { Soil mixtures } \\
\text { (sand and } \\
\text { gravel with } \\
\text { small } \\
\text { gravel),little } \\
\text { fines }\end{array}$ & $\begin{array}{c}\text { Mixture of } \\
\text { fine soils (silt } \\
\text { and clay), } \\
\text { with fines. }\end{array}$ \\
\hline $\begin{array}{l}\text { Upper limit of water } \\
\text { content, } \% \text { of dry weight. }\end{array}$ & --- & 9 to 12 & 9 to 18 & 6 to 30 \\
\hline Compaction technique & & $\begin{array}{l}\% \text { proc } \\
(\% \text { rela }\end{array}$ & $\begin{array}{l}\text { density } \\
\text { density) }\end{array}$ & \\
\hline $\begin{array}{l}\text { Mechanical compactor } \\
\text { (roller, rammer, etc) }\end{array}$ & $\begin{array}{l}95 \text { to } 100 \\
\text { ( } 75 \text { to } 100)\end{array}$ & $\begin{array}{l}95 \text { to } 100 \\
\text { ( } 80 \text { to } 100 \text { ) }\end{array}$ & 95 to 100 & 90 to 100 \\
\hline $\begin{array}{l}\text { Density increased by } \\
\text { portable vibrators }\end{array}$ & $\begin{array}{l}80 \text { to } 95 \\
\text { ( } 60 \text { to } 75 \text { ) }\end{array}$ & $\begin{array}{l}80 \text { to } 95 \\
\text { ( } 60 \text { to } 80 \text { ) }\end{array}$ & 80 to 95 & 75 to 90 \\
\hline Saturation compaction & $\begin{array}{l}80 \text { to } 95 \\
\text { ( } 60 \text { to } 75 \text { ) }\end{array}$ & $\begin{array}{l}80 \text { to } 95 \\
\text { ( } 60 \text { to } 80 \text { ) }\end{array}$ & ---- & ---- \\
\hline Placed manually & $\begin{array}{l}60 \text { to } 80 \\
\text { ( } 40 \text { to } 60 \text { ) }\end{array}$ & ---- & ---- & ---- \\
\hline Compressed manually & ---- & $\begin{array}{l}60 \text { to } 80 \\
\text { ( } 40 \text { to } 60 \text { ) }\end{array}$ & 60 to 80 & 60 to 75 \\
\hline Dumped & $\begin{array}{l}60 \text { to } 80 \\
(40 \text { to } 60)\end{array}$ & $\begin{array}{l}60 \text { to } 80 \\
(50 \text { to } 60)\end{array}$ & 60 to 80 & 60 to 75 \\
\hline
\end{tabular}


Table 3.6: Reaction modulus of the soil (E') (ASTM D2321, 1995; ASTM D2487, 2000).

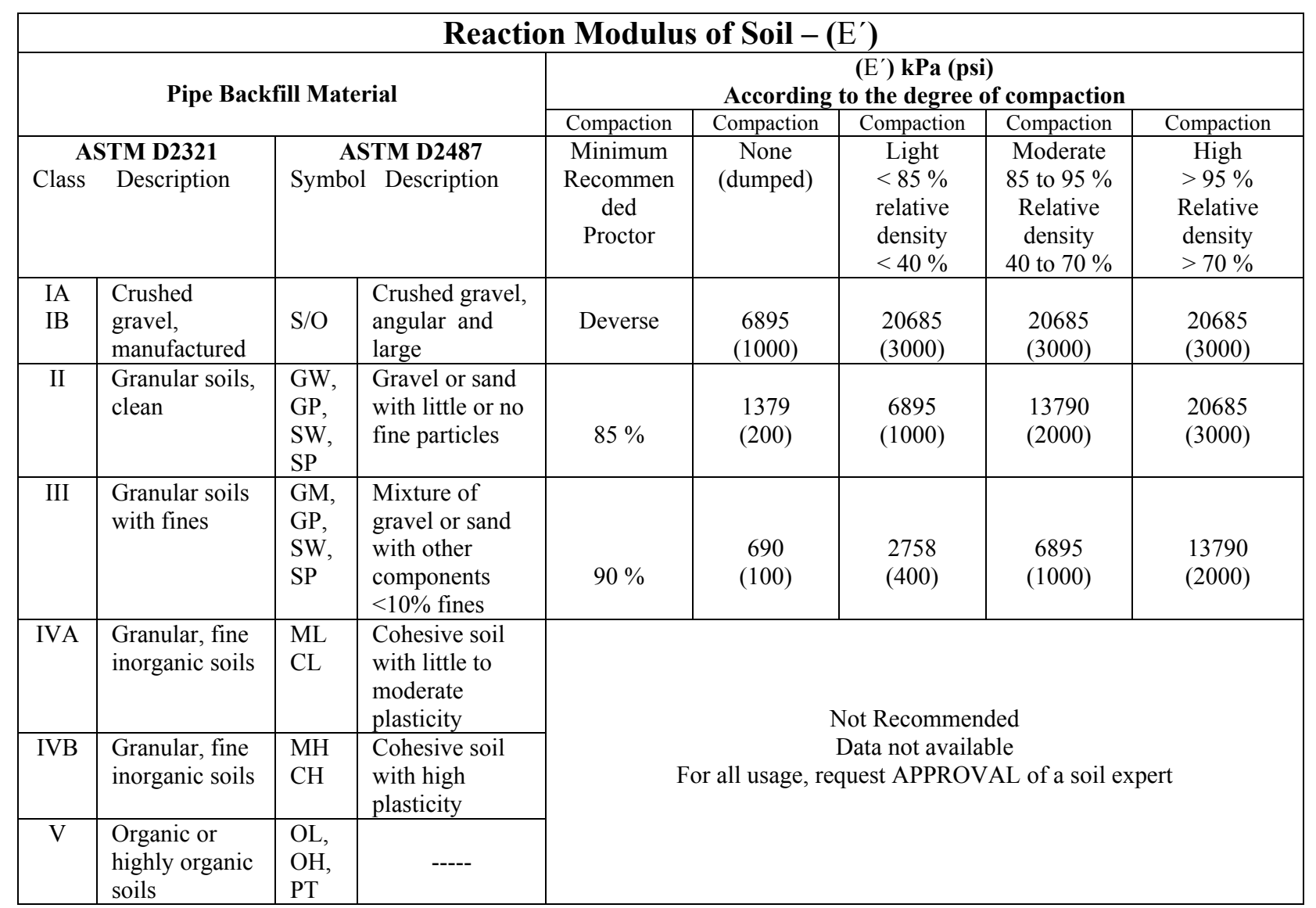




\subsection{High-density polyethylene (HDPE) properties}

High-density polyethylene (HDPE) is a versatile material with desirable characteristics, such as resistant to abrasion, corrosion and chemical scouring for use as an underground structure. HDPE pipes are structurally strong and have the ability to support large loads. One of the significant characteristics of HDPE material is its longterm structural stability which may be due to its ability to relax under external stress. The HDPE pipe relaxes over time, allowing the load to be transferred to the adjacent soil (Moser, 1990; Goddard and Gabriel, 1998).

Density and molecular weight of HDPE materials are described as two of the most important properties that influence the manufacturing process and the finished product. Density or volume mass of polyethylene (PE) is characterized by the possibility of linking the maximum number of molecular chains in the same space. Polyethylene in general does not allow tight bonding, which results in a relatively weak density product known as Low-density polyethylene (LDPE). With the development of new polyethylenes such as Medium-density polyethylene (MDPE) and High-density polyethylene (HDPE), it has been possible to attain a better linkage by composition of short chains. A high pressure process is used to attain a high-density polyethylene (HDPE) which is the material of interest in this report (Solena, Inc., 2002). The American Society for Testing of Materials (ASTM D2412, 2000) has established a standard verification method to determine type polyethylene (PE) based on density as shown in Table 3.7.

Table 3.7 Classification of PE based on density (ASTM D2412, 2000)

\begin{tabular}{|c|c|}
\hline TYPE & DENSITY $\left(\mathbf{l b} / \mathbf{i n}^{3}\right)$ \\
\hline I & $0.910-0.925$ (LDPE) \\
\hline II & $0.926-0.940$ (MDPE) \\
\hline III & $0.941-0.959$ (HDPE) \\
\hline IV & 0.960 and higher (high, homo polymer) \\
\hline
\end{tabular}

$1 \mathrm{psi}=6.89 \mathrm{kN} / \mathrm{m}^{2} ; 1 \mathrm{pcf}=16 \mathrm{~kg} / \mathrm{m}^{3} ; 1$ inch $=2.54 \mathrm{~cm}$. 
Molecular weight is defined as the sum of the atomic weight of each atom in a particular molecule. Longer the molecular chains have higher molecular weights. The molecular weight exerts a great influence on the extrusion process, and the mechanical and physical properties (Solena, Inc., 2002). Thus, the increase in molecular weight improves the long-term hardness, the ductility and the fatigue endurance. The effects of density and molecular weight distribution on physical properties are summarized in Table 3.8 (Plastic Pipe Institute, 2003).

Table 3.8: Effects of density and molecular weight distribution on HDPE material (Plastic Pipe Institute, 2003).

EFFECTS OF DENSITY AND MOLECULAR WEIGHT DISTRIBUTION ON
PHYSICAL PROPERTIES

\begin{tabular}{|c|c|c|}
\hline Property & $\begin{array}{c}\text { As Density Increases, } \\
\text { Property: }\end{array}$ & $\begin{array}{c}\text { As Molecular Weight } \\
\text { Distribution Broadens, } \\
\text { Property: }\end{array}$ \\
\hline Tensile Strength & Increases & \\
\hline Stiffness & Increases & Decreases Slightly \\
\hline Impact Strength & Decreases & Decreases \\
\hline $\begin{array}{c}\text { Low Temperature } \\
\text { Brittleness }\end{array}$ & Increases & Decreases \\
\hline Abrasion Resistance & Increases & \\
\hline Hardness & Increases & \\
\hline Softening Point & Increases & Increases \\
\hline Stress Crack Resistance & Decreases & Increases \\
\hline Permeability & Decreases & \\
\hline Chemical Reistance & Increases & \\
\hline Shrinkage & Decreases & Increases \\
\hline Melt Strength & & Increases \\
\hline Gloss & Increases & Decreases \\
\hline Haze & Decreases & \\
\hline
\end{tabular}




\subsubsection{Flexural Modulus}

The flexural strength of a material is its ability to resist deformation under load. For materials such as HDPE that do not break, the load at yield (typically 5\% deformation for HDPE) is reported as the flexural strength or flexural yield strength. The test to determine flexural strength is done under compressive stress at the concave surface of the HDPE pipe. The Figure 3.2 shows a schematic diagram of the testing apparatus specified by American Society of Testing and Materials (ASTM D790, 2000). This test is used to measure the flexural modulus of the material. Flexural modulus of a material is defined as the ratio of stress to strain under flexural loading. Typical values of flexural strength and flexural modulus of a polyethylene material are given as $40 \mathrm{MPa}$ and 0.7 GPa, respectively, as reported in the literature (ASTM D790, 2000).

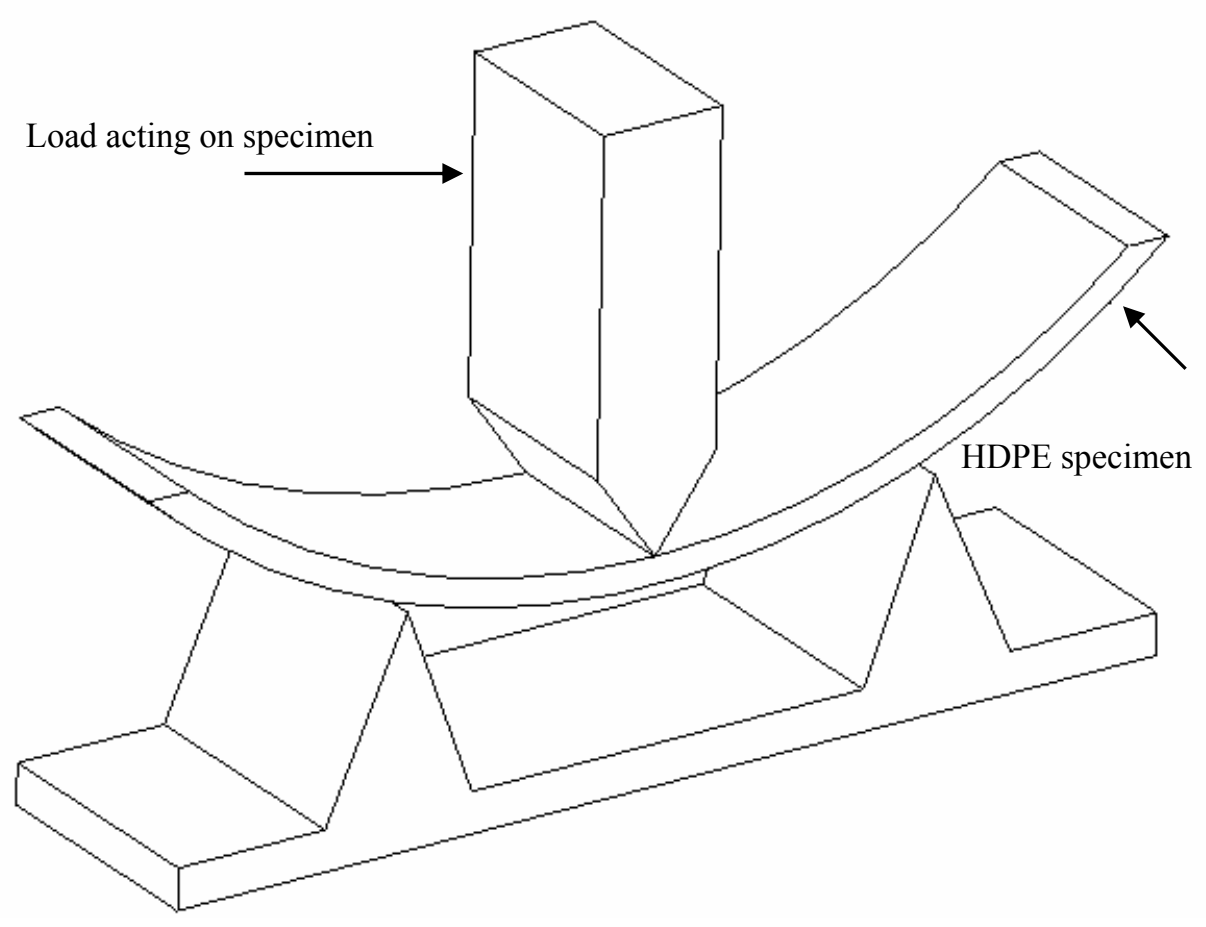

Figure 3.2: Schematic diagram of the testing apparatus to determine flexural strength (ASTM D790, 2000) 


\subsubsection{Flexible Pipe Design Criteria}

Design of High-Density Polyethylene (HDPE) pipe requires knowledge of its material properties, installation conditions and external loads. All these factors are combined to predict the behavior of the installed pipe. Three most essential parameters in the design and analysis of flexible pipes are (Moser, 1990):

$>\operatorname{Load}($ Dead load + Live load).

$>$ Soil stiffness around the pipe.

$>$ Pipe stiffness.

For the analysis and design of buried pipes, external soil pressures on the pipes must be known. Vertical soil pressure at the top of the pipe is caused by:

$>$ Dead load due to the weight of the soil at the top of the pipe.

$>$ Live load due to the surface loads at the top of the pipe.

For design, the total vertical pressure $(\mathrm{P})$ at the top of the pipe is given as:

$$
\mathrm{P}=\mathrm{P}_{\mathrm{d}}+\mathrm{P}_{\mathrm{L}}
$$

Where,

$\mathrm{P}_{\mathrm{d}}=$ Vertical Pressure due to dead load.

$\mathrm{P}_{\mathrm{L}}=$ Vertical Pressure due to live load.

\subsubsection{Vertical Pressure due to dead load $\left(P_{d}\right)$}

Dead load is the vertical load due to the weight of the soil at a given depth H. In the design of buried pipes, $\mathrm{H}$ is the height of the soil cover over a pipe. Total pressure $\left(\mathrm{P}_{\mathrm{d}}\right)$ is the weight of the soil, including its water content, per unit area. The total vertical pressure due to dead load is given by:

$P_{d}=\sum_{l=1}^{N} \gamma_{i} H_{i}$

Where,

$\gamma_{i}=$ Total unit weight of the soil in a given layer

$H_{i}=$ Height of the layer "i $i$ " 
$P_{d}=$ Pressure due to weight of the soil at depth $\mathrm{H}$

$\mathrm{N}=$ Number of layers.

\subsubsection{Vertical Pressure due to live load $\left(P_{L}\right)$}

Flexible pipes installed under a roadway must, in addition to dead weight due to soil, resist the effects of live loads generated by cars, trucks and trains. Vertical soil pressure $\left(\mathrm{P}_{\mathrm{L}}\right)$ due to live load is the pressure at the top of the buried pipe caused by external loads at ground surface. For a single concentrated load $\mathrm{W}$ on the surface shown in Figure 3.3, the vertical soil pressure at point $\mathrm{A}$ at the top of the pipe is given as (Watkins, 1999):

$$
\sigma=\frac{N W}{H^{2}}
$$

Where,

$\mathrm{W}=$ concentrated surface load (dual-wheel)

$\mathrm{H}=$ height of the soil cover over the top of the pipe

$\mathrm{X}=$ distance between the load and the pipe center

$\mathrm{N}=$ boussinesq coefficient (from the line of action of the load $\mathrm{W}$ )

$$
=\frac{3(H / X)^{5}}{2 \pi}
$$

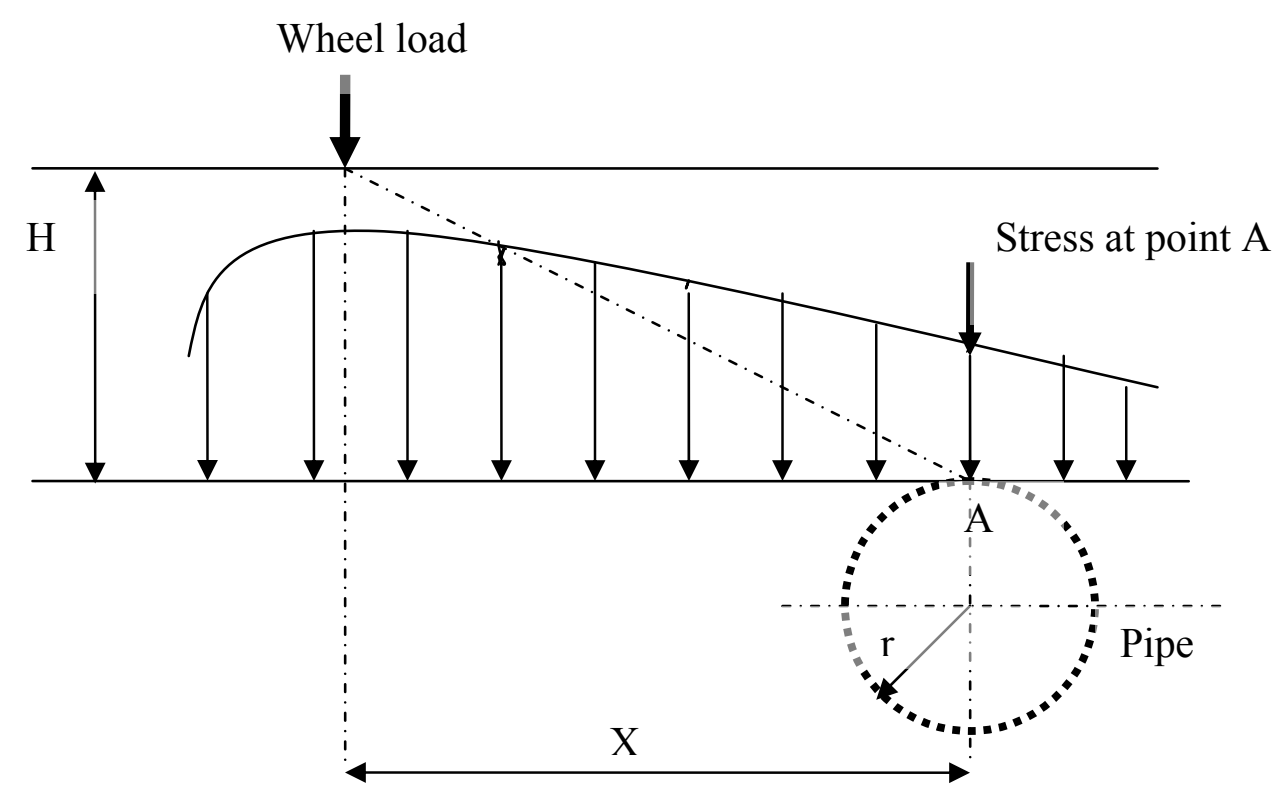

Figure 3.3 Vertical soil pressures at a depth (H) (Watkins, 1999). 
Soil stiffness (Soil modulus) is usually expressed in terms of $E^{\prime}$ (effective soil modulus), which is a function of soil properties such as soil density, soil type, and moisture content. It has been found that soil density is the most influencing factor in determining the soil stiffness. The pipe stiffness is usually controlled by material properties of the pipe. The relationships related to pipe stiffness are given below (Moser, 1990).

$>$ Stiffness factor $=$ EI

$>$ Pipe stiffness $=\mathrm{F} / \Delta \mathrm{y}=6.7 \mathrm{EI} / \mathrm{r}^{3}$

$>$ Ring stiffness $=\mathrm{EI} / \mathrm{r}^{3}$

Where, $\mathrm{E}=$ modulus of elasticity of pipe material $\left(\mathrm{lb} / \mathrm{in}^{2}\right)$

$\mathrm{I}=$ moment of inertia of the wall cross-section per unit length of pipe (in $/$ in)

$\mathrm{r}=$ mean radius of pipe (in)

$\mathrm{F}=$ vertical force $(\mathrm{lb})$

$\Delta y=$ vertical deflection (in)

From the above relations it can be stated that the pipe stiffness factor (EI) is an essential parameter in calculating the pipe stiffness. The stiffness factor is influenced by the geometry of the cross-section, thickness and elastic modulus. The minimum stiffness determined in accordance with American Society of Testing and Materials (ASTM D2412, 2000) and the pipe-section properties of commercially available pipes are given in the Table 3.9 and Table 3.10, respectively. The HDPE pipe properties used in the finite element analysis presented in this report are given in Table 3.11.

Table 3.9: Minimum pipe stiffness at various diameters (ADS, Inc., 2002)

\begin{tabular}{|c|c|c|c|}
\hline Diameter & Pipe Stiffness, & Diameter (mm) & Pipe Stiffness \\
\hline $100 \mathrm{~mm}$ (4") & $340 \mathrm{KPa}(50 \mathrm{psi})$ & $525 \mathrm{~mm}$ (21") & $260 \mathrm{KPa}(37.7 \mathrm{psi})$ \\
\hline $150 \mathrm{~mm}\left(6^{\prime \prime}\right)$ & $340 \mathrm{KPa}$ (50psi) & $600 \mathrm{~mm}$ (24”) & $235 \mathrm{KPa}(34 p s i)$ \\
\hline $200 \mathrm{~mm}\left(8^{\prime \prime}\right)$ & $340 \mathrm{KPa}(50 \mathrm{psi})$ & $675 \mathrm{~mm}\left(26.5^{\prime \prime}\right)$ & $205 \mathrm{KPa}(29.73 \mathrm{psi})$ \\
\hline $250 \mathrm{~mm}(10 ”)$ & $340 \mathrm{KPa}(50 \mathrm{psi})$ & $750 \mathrm{~mm}$ (30”) & $195 \mathrm{KPa}(28 p s i)$ \\
\hline $300 \mathrm{~mm}$ (12”) & $345 \mathrm{KPa}(50 \mathrm{psi})$ & $900 \mathrm{~mm}\left(36^{\prime \prime}\right)$ & $150 \mathrm{KPa}(22 \mathrm{psi})$ \\
\hline $375 \mathrm{~mm}$ (15”) & $290 \mathrm{KPa}(42 \mathrm{psi})$ & $1050 \mathrm{~mm}$ (42”) & $140 \mathrm{KPa}(20 p s i)$ \\
\hline $450 \mathrm{~mm}\left(18^{\prime \prime}\right)$ & $275 \mathrm{KPa}(40 \mathrm{psi})$ & $1200 \mathrm{~mm}\left(48^{\prime \prime}\right)$ & $125 \mathrm{KPa}$ (18psi) \\
\hline
\end{tabular}

$1 \mathrm{psi}=6.89 \mathrm{kN} / \mathrm{m}^{2} ; 1 \mathrm{pcf}=16 \mathrm{~kg} / \mathrm{m}^{3} ; 1$ inch $=2.54 \mathrm{~cm}$. 
Table 3.10: Single wall pipe section properties (ADS, Inc., 2002)

\begin{tabular}{|c|c|c|c|c|c|c|c|}
\hline $\begin{array}{l}\text { Nominal } \\
\text { Diameter }\end{array}$ & $\begin{array}{c}\text { Inside } \\
\text { Diameter, } \\
\text { Average }\end{array}$ & $\begin{array}{c}\text { Outside } \\
\text { Diameter, } \\
\text { Average }\end{array}$ & $\begin{array}{c}\text { Minimum } \\
\text { Pipe Stiffness } \\
\text { a } 5 \% \\
\text { Deflection }\end{array}$ & $\begin{array}{l}\text { Weight kg./6m } \\
\text { (lbs./20 ft) }\end{array}$ & $\begin{array}{c}\text { Area of } \\
\text { section } \\
\mathrm{mm}^{2} / \mathbf{m m}\end{array}$ & $\begin{array}{c}\text { Moment of } \\
\text { inertia (I) } \\
\mathrm{cm}^{4} / \mathrm{cm}\end{array}$ & $\begin{array}{l}\text { Distance inside } \\
\text { diameter to } \\
\text { neutral axis (C) }\end{array}$ \\
\hline $\begin{array}{c}75 \mathrm{~mm} \\
(3 ”)\end{array}$ & $\begin{array}{l}79 \mathrm{~mm} \\
(3.12 ”)\end{array}$ & $\begin{array}{l}93 \mathrm{~mm} \\
(3.66 ”)\end{array}$ & $\begin{array}{c}240 \mathrm{kN} / \mathrm{m}^{2} \\
35 \mathrm{psi}\end{array}$ & $\begin{array}{c}1.97 \mathrm{~kg} \\
(4.40 \mathrm{lbs})\end{array}$ & $\begin{array}{c}1.88 \\
\left(0.074 \mathrm{in}^{2} / \mathrm{in}\right)\end{array}$ & $\begin{array}{c}0.0066 \\
\left(0.0004 \mathrm{in}^{4} / \mathrm{in}\right)\end{array}$ & $\begin{array}{c}2.97 \\
(0.117 \mathrm{in})\end{array}$ \\
\hline $\begin{array}{c}100 \mathrm{~mm} \\
(4 ”)\end{array}$ & $\begin{array}{l}102 \mathrm{~mm} \\
(4.03 ”)\end{array}$ & $\begin{array}{l}120 \mathrm{~mm} \\
(4.71 ”)\end{array}$ & $\begin{array}{c}240 \mathrm{kN} / \mathrm{m}^{2} \\
35 \mathrm{psi}\end{array}$ & $\begin{array}{c}2.81 \mathrm{~kg} \\
(6.30 \mathrm{lbs})\end{array}$ & $\begin{array}{c}2.06 \\
\left(0.081 \mathrm{in}^{2} / \mathrm{in}\right)\end{array}$ & $\begin{array}{c}0.0169 \\
\left(0.001 \mathrm{in}^{4} / \mathrm{in}\right) \\
\end{array}$ & $\begin{array}{c}4.29 \\
(0.169 \text { in })\end{array}$ \\
\hline $\begin{array}{c}125 \mathrm{~mm} \\
\left(5^{\prime \prime}\right)\end{array}$ & $\begin{array}{l}127 \mathrm{~mm} \\
(4.99 ”)\end{array}$ & $\begin{array}{c}148 \mathrm{~mm} \\
(5.81 ”)\end{array}$ & $\begin{array}{c}240 \mathrm{kN} / \mathrm{m}^{2} \\
35 \mathrm{psi}\end{array}$ & $\begin{array}{c}4.43 \mathrm{~kg} \\
(9.90 \mathrm{lbs})\end{array}$ & $\begin{array}{c}2.34 \\
\left(0.092 \mathrm{in}^{2} / \mathrm{in}\right)\end{array}$ & $\begin{array}{c}0.0229 \\
\left(0.0014 \mathrm{in}^{4} / \mathrm{in}\right)\end{array}$ & $\begin{array}{c}4.78 \\
(0.188 \text { in })\end{array}$ \\
\hline $\begin{array}{c}150 \mathrm{~mm} \\
(6 ”)\end{array}$ & $\begin{array}{c}151 \mathrm{~mm} \\
(5.95 ”)\end{array}$ & $\begin{array}{c}176 \mathrm{~mm} \\
(6.92 ”)\end{array}$ & $\begin{array}{c}240 \mathrm{kN} / \mathrm{m}^{2} \\
35 \mathrm{psi}\end{array}$ & $\begin{array}{c}6.39 \mathrm{~kg} \\
(14.30 \mathrm{lbs})\end{array}$ & $\begin{array}{c}3.15 \\
\left(0.124 \mathrm{in}^{2} / \mathrm{in}\right)\end{array}$ & $\begin{array}{c}0.0459 \\
\left(0.0028 \mathrm{in}^{4} / \mathrm{in}\right)\end{array}$ & $\begin{array}{c}6.22 \\
(0.245 \mathrm{in})\end{array}$ \\
\hline $\begin{array}{c}200 \mathrm{~mm} \\
\left(8^{\prime \prime}\right)\end{array}$ & $\begin{array}{c}207 \mathrm{~mm} \\
(8.14 ”)\end{array}$ & $\begin{array}{c}240 \mathrm{~mm} \\
\left(9.45^{\prime \prime}\right)\end{array}$ & $\begin{array}{c}240 \mathrm{kN} / \mathrm{m}^{2} \\
35 \mathrm{psi}\end{array}$ & $\begin{array}{l}11.02 \mathrm{~kg} \\
(24.60 \mathrm{lbs})\end{array}$ & $\begin{array}{c}3.25 \\
\left(0.128 \mathrm{in}^{2} / \mathrm{in}\right)\end{array}$ & $\begin{array}{c}0.1082 \\
\left(0.0066 \mathrm{in}^{4} / \mathrm{in}\right)\end{array}$ & $\begin{array}{c}8.08 \\
(0.318 \mathrm{in})\end{array}$ \\
\hline $\begin{array}{c}250 \mathrm{~mm} \\
(10 ")\end{array}$ & $\begin{array}{l}255 \mathrm{~mm} \\
(10.05 ”)\end{array}$ & $\begin{array}{l}300 \mathrm{~mm} \\
(11.83 ”)\end{array}$ & $\begin{array}{c}240 \mathrm{kN} / \mathrm{m}^{2} \\
35 \mathrm{psi}\end{array}$ & $\begin{array}{c}16.23 \mathrm{~kg} \\
(36.30 \mathrm{lbs})\end{array}$ & $\begin{array}{c}3.48 \\
\left(0.137 \mathrm{in}^{2} / \mathrm{in}\right) \\
\end{array}$ & $\begin{array}{c}0.1966 \\
\left(0.0120 \mathrm{in}^{4} / \mathrm{in}\right)\end{array}$ & $\begin{array}{c}11.20 \\
(0.441 \mathrm{in})\end{array}$ \\
\hline $\begin{array}{c}300 \mathrm{~mm} \\
(12 ”)\end{array}$ & $\begin{array}{l}306 \mathrm{~mm} \\
(12.04 ”)\end{array}$ & $\begin{array}{l}366 \mathrm{~mm} \\
(14.41 ”)\end{array}$ & $\begin{array}{c}345 \mathrm{kN} / \mathrm{m}^{2} \\
50 \mathrm{psi}\end{array}$ & $\begin{array}{c}26.56 \mathrm{~kg} \\
(59.40 \mathrm{lbs})\end{array}$ & $\begin{array}{c}5.23 \\
\left(0.206 \mathrm{in}^{2} / \mathrm{in}\right)\end{array}$ & $\begin{array}{c}0.5211 \\
\left(0.0318 \mathrm{in}^{4} / \mathrm{in}\right)\end{array}$ & $\begin{array}{c}15.88 \\
(0.625 \text { in })\end{array}$ \\
\hline $\begin{array}{c}375 \mathrm{~mm} \\
\left(15^{\prime \prime}\right)\end{array}$ & $\begin{array}{l}378 \mathrm{~mm} \\
(14.87 ”)\end{array}$ & $\begin{array}{l}444 \mathrm{~mm} \\
(17.49 ”)\end{array}$ & $\begin{array}{c}290 \mathrm{kN} / \mathrm{m}^{2} \\
42 \mathrm{psi}\end{array}$ & $\begin{array}{c}36.39 \mathrm{~kg} \\
(81.40 \mathrm{lbs})\end{array}$ & $\begin{array}{c}4.67 \\
\left(0.184 \mathrm{in}^{2} / \mathrm{in}\right)\end{array}$ & $\begin{array}{c}0.5440 \\
\left(0.0332 \mathrm{in}^{4} / \mathrm{in}\right)\end{array}$ & $\begin{array}{c}14.86 \\
(0.585 \mathrm{in})\end{array}$ \\
\hline $\begin{array}{c}450 \mathrm{~mm} \\
\left(18^{\prime \prime}\right)\end{array}$ & $\begin{array}{l}454 \mathrm{~mm} \\
(17.86 ")\end{array}$ & $\begin{array}{l}534 \mathrm{~mm} \\
(21.04 ”)\end{array}$ & $\begin{array}{c}275 \mathrm{kN} / \mathrm{m}^{2} \\
40 \mathrm{psi}\end{array}$ & $\begin{array}{c}53.51 \mathrm{~kg} \\
(119.70 \mathrm{lbs})\end{array}$ & $\begin{array}{c}6.22 \\
\left(0.245 \mathrm{in}^{2} / \mathrm{in}\right) \\
\end{array}$ & $\begin{array}{c}1.062 \\
\left(0.0648 \mathrm{in}^{4} / \mathrm{in}\right)\end{array}$ & $\begin{array}{c}20.02 \\
(0.788 \text { in })\end{array}$ \\
\hline $\begin{array}{c}600 \mathrm{~mm} \\
(24 ”)\end{array}$ & $\begin{array}{l}600 \mathrm{~mm} \\
(23.61 ”)\end{array}$ & $\begin{array}{l}699 \mathrm{~mm} \\
(27.50 ”)\end{array}$ & $\begin{array}{c}235 \mathrm{kN} / \mathrm{m}^{2} \\
34 \mathrm{psi}\end{array}$ & $\begin{array}{c}100.33 \mathrm{~kg} \\
(224.40 \mathrm{lbs})\end{array}$ & $\begin{array}{c}8.99 \\
\left(0.354 \mathrm{in}^{2} / \mathrm{in}\right)\end{array}$ & $\begin{array}{c}2.161 \\
\left(0.1318 \mathrm{in}^{4} / \mathrm{in}\right)\end{array}$ & $\begin{array}{c}25.38 \\
(0.999 \text { in })\end{array}$ \\
\hline
\end{tabular}

$1 \mathrm{psi}=6.89 \mathrm{kN} / \mathrm{m}^{2} ; 1 \mathrm{pcf}=16 \mathrm{~kg} / \mathrm{m}^{3} ; 1$ inch $=2.54 \mathrm{~cm}$. 
Table 3.11: Material properties for 6-inch and 8-inch diameter HDPE pipes

\begin{tabular}{|l|c|c|}
\hline Parameters & 6 inch HDPE pipe & 6 inch HDPE pipe \\
\hline Young's modulus (E) psi & 62287 & 66873 \\
\hline Poisson's ratio (v) & 0.25 & 0.25 \\
\hline Mass density $(\rho)^{*}$ pcf & 60 & 60 \\
\hline
\end{tabular}

* Reference (Plastic pipe institute (PPI), 2003)

$1 \mathrm{psi}=6.89 \mathrm{kN} / \mathrm{m}^{2} ; 1 \mathrm{pcf}=16 \mathrm{~kg} / \mathrm{m}^{3} ; 1$ inch $=2.54 \mathrm{~cm}$.

\subsubsection{Deflection Equations}

The structural capacity of a corrugated HDPE pipe can be determined by calculating the deflection of the pipe under installation conditions. The ring deflection of buried flexible circular pipes can be computed by using the modified Iowa formula (Spangler, 1941). This formula is popular in predicting the deflection of flexible pipes. The pipe deflection can be expressed as:

$$
\Delta y=\frac{D_{f} K_{s} W_{c} r^{3}}{E I+0.061 E^{\prime} r^{3}}
$$

Where,

$\Delta y=$ horizontal deflection

$\mathrm{K}_{\mathrm{s}}=$ bedding constant $($ generally $=0.1)$

$\mathrm{D}_{\mathrm{f}}=$ deflection lag factor (1.0 when prism load is used)

$\mathrm{W}_{\mathrm{c}}=$ Marston load per unit length $\left(\mathrm{W}_{\mathrm{c}} \approx \mathrm{PD}\right)$

$\mathrm{P}_{\mathrm{L}}=$ live load over pipe

$\mathrm{P}_{\mathrm{d}}=$ dead load over pipe

$\mathrm{P}=$ vertical soil pressure on top of the pipe $\left(\mathrm{P}=\mathrm{P}_{\mathrm{d}}+\mathrm{P}_{\mathrm{L}}\right)$

$\mathrm{D}=$ mean circular diameter of the pipe

$r=$ mean radius of the pipe $(D / 2)$

$\mathrm{EI}=$ stiffness of the pipe per unit length

$E^{\prime}=$ modulus of soil reaction 
Equation (3.12) can be used to predict deflections of a buried pipe if the pipe stiffness $(E I)$, dead load $\left(\mathrm{P}_{\mathrm{d}}\right)$, live load $\left(\mathrm{P}_{\mathrm{L}}\right)$, and backfill conditions $\left(E^{\prime}\right)$ are known. Deflection $\Delta y$ is acceptable as long as it does not exceed the functional limits of the soilpipe system. In highway installations, the deflection is generally limited to $6.5 \%$ of the pipe diameter for a flexible pipe. It also depends on the quality of backfill (Moser, 1990). Ideally a 5\% change in pipe diameter is assumed as the pipe failure condition (Moser, 1990). 


\section{CHAPTER 4}

\section{NUMERICAL ANALYSIS PROCEDURES}

\subsection{Introduction}

The most popular among numerical analysis techniques, Finite Element Method (FEM) is used in this research to analyze the structural performance of buried HDPE pipes. Through the years, the FEM technique has been extended into other engineering fields such as fluid mechanics, geotechnical engineering and ground water flow modeling (Cook et al., 2002; Zienkewicz and Taylor, 1991).

By incorporating the soil-structure interaction mechanics into the analysis, Finite Element Method can be used to analyze complex problems in geotechnical engineering. The modeling of the nonlinear stress-strain properties of soil has been accommodated through incremental analysis and iterative solution procedures. Various structural properties, loading conditions, and boundary conditions can be incorporated into the analysis. Finite Element Method of analysis is advantages in comparison to experimental work, which involves costly and time-consuming laboratory work. However, the analyst should note that the results from the finite element analysis have to be calibrated by comparing them with physical measurements. Finite element method is a powerful numerical method that can be used in the analysis of buried pipes.

\subsection{The finite element analysis}

Details of the finite element analysis are well documented and can be found elsewhere (Cook et al., 2002; Zienkewicz and Taylor, 1991). The mathematical details of the finite element analysis are presented briefly in the following section for the completeness.

\subsubsection{Formulation of the Stiffness Matrix}

Finite element method is a mathematical technique, where a continuum model is idealized by dividing it into a number of finite elements. Theses elements are connected to their adjacent elements at nodes. Special shape functions are used to relate displacements 
along the element boundaries to the nodal displacements and to specify the displacement compatibility between adjacent elements. Once the continuum has been discritized, an analysis of the system is performed using global equilibrium equations. The governing equations can be expressed as:

$$
[\bar{K}]\{r\}=\{R\}
$$

Where, $[\bar{K}]=$ global stiffness matrix

$$
\begin{aligned}
& \{r\}=\text { global displacement vector } \\
& \{R\}=\text { global load vector }
\end{aligned}
$$

The global equilibrium equations are obtained by the assembly of element equations. The details of the derivations are given elsewhere (Cook et al., 2002; Zienkewicz and Taylor, 1991). A brief description of the mathematical formulation of element equations is given below. In the current research, four node isoparametric quadrilateral elements and three dimensional brick elements are used as shown in Figure 4.1 and 4.2, respectively. 


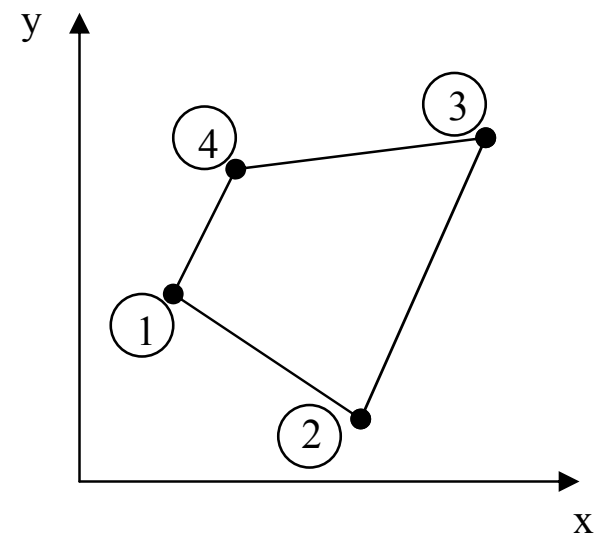

(a) Global coordinate system

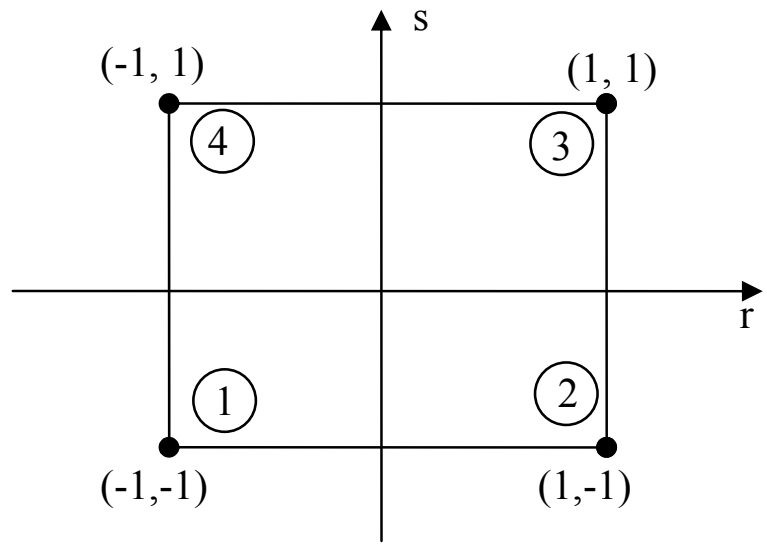

(b) Local coordinate system

Figure 4.1: Four node isoparametric element 


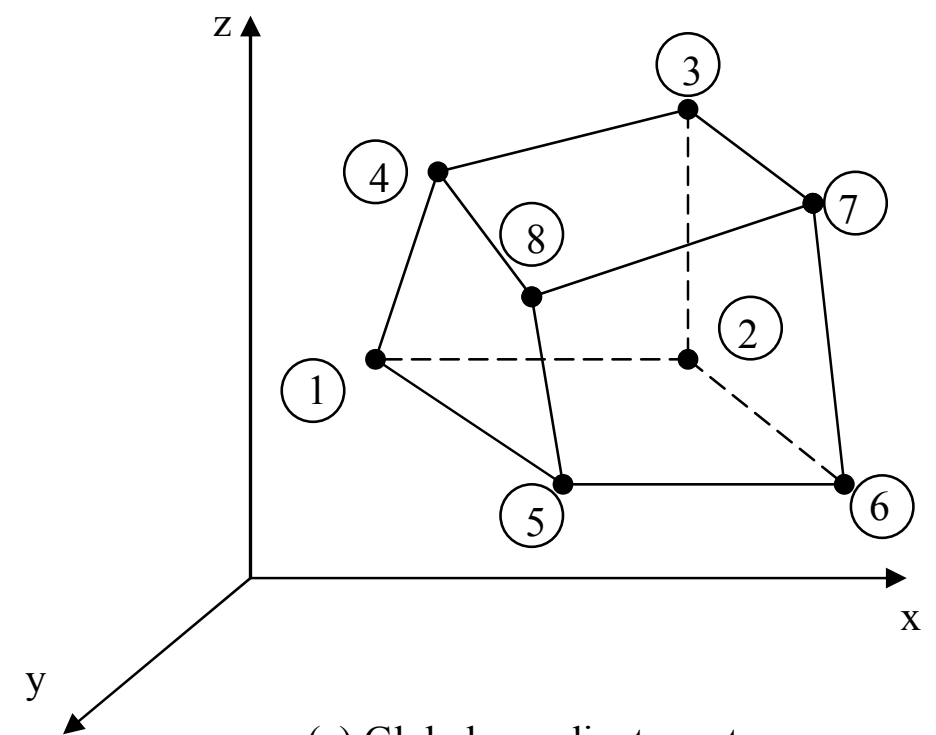

(a) Global coordinate system

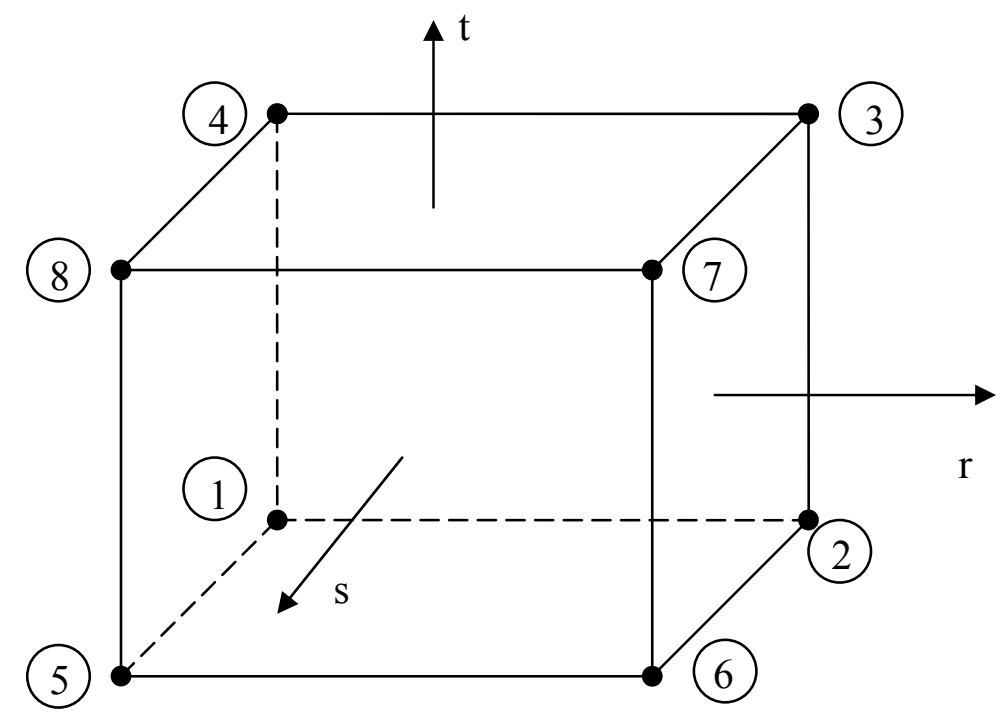

(b) Local coordinate system

Figure 4.2: Three dimensional brick element 


\subsubsection{Four node isoparametric element formulation}

A 4-node isoparametric element with displacements $\mathrm{u}$ and $\mathrm{v}$ at a given node in the $\mathrm{x}$ and $\mathrm{y}$ directions are shown in Figure 4.3.

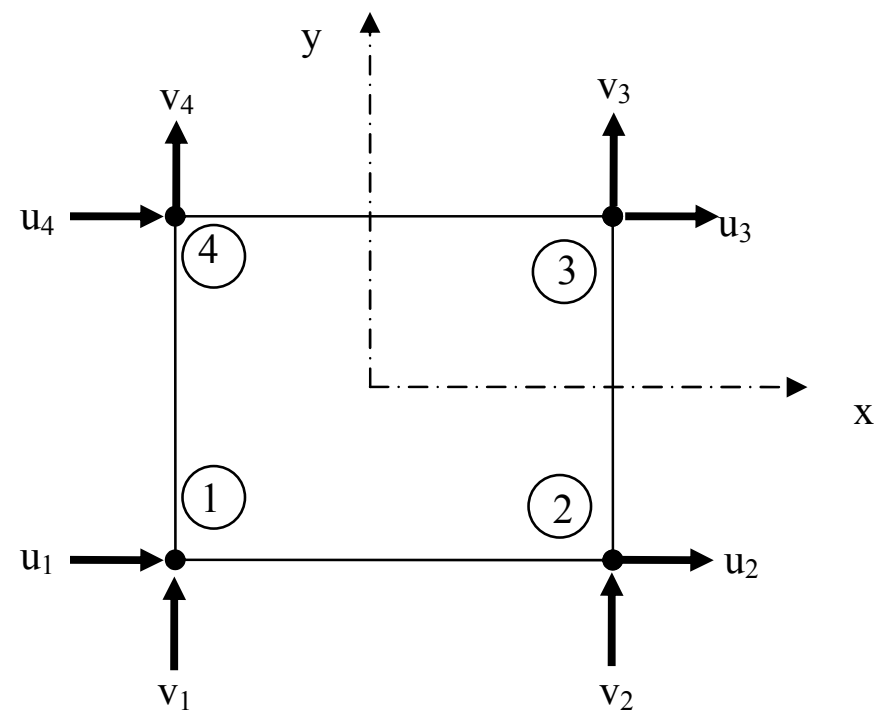

Figure 4.3: Nodal displacements along $x$ and $y$ directions for isoparametric element

The quantities $\mathrm{u}_{1}, \mathrm{u}_{2}, \mathrm{u}_{3}$ and $\mathrm{u}_{4}$ shown in Figure 4.3 denote the nodal displacements in the $\mathrm{x}$-direction, while the quantities $\mathrm{v}_{1}, \mathrm{v}_{2}, \mathrm{v}_{3}$ and $\mathrm{v}_{4}$ denote the nodal displacements in the $\mathrm{y}$-direction. The displacements $\mathrm{u}$ and $\mathrm{v}$ at a given point can be expressed by using interpolation functions and nodal displacements as follows:

$$
\begin{aligned}
& \mathrm{u}=\mathrm{N}_{1} \mathrm{u}_{1}+\mathrm{N}_{2} \mathrm{u}_{2}+\mathrm{N}_{3} \mathrm{u}_{3}+\mathrm{N}_{4} \mathrm{u}_{4} \\
& \mathrm{v}=\mathrm{N}_{1} \mathrm{v}_{1}+\mathrm{N}_{2} \mathrm{v}_{2}+\mathrm{N}_{3} \mathrm{v}_{3}+\mathrm{N}_{4} \mathrm{v}_{4}
\end{aligned}
$$

Where, $\mathrm{N}_{1}, \mathrm{~N}_{2}, \mathrm{~N}_{3}$ and $\mathrm{N}_{4}$ are interpolation functions in local coordinates. The above equation can be written in matrix form as: 


$$
\left\{\begin{array}{l}
u \\
v
\end{array}\right\}=\left[\begin{array}{cccccccc}
N_{1} & 0 & N_{2} & 0 & N_{3} & 0 & N_{4} & 0 \\
0 & N_{1} & 0 & N_{2} & 0 & N_{3} & 0 & N_{4}
\end{array}\right]\left\{\begin{array}{l}
u_{1} \\
v_{1} \\
u_{2} \\
v_{2} \\
u_{3} \\
v_{3} \\
u_{4} \\
v_{4}
\end{array}\right\}
$$

or

$\{U\}=[N]\{q\}$

Where,

$\{U\}=\left\{\begin{array}{l}u \\ v\end{array}\right\}$

$\{q\}^{T}=\left\{u_{1}, v_{1}, u_{1}, v_{2}, u_{1}, v_{3}, u_{1}, v_{4}\right\}$

The interpolation functions can be written as:

$N_{i}=\frac{1}{4}\left(1+r r_{i}\right)\left(1+s s_{i}\right)$

Where, $\mathrm{s}$ and $\mathrm{t}$ correspond to the local coordinates which vary from -1 to +1 , and the subscript " $\mathrm{i}$ " denotes the node to which the interpolation function is attached. For a plain element the interpolation functions are given as:

$$
\begin{aligned}
& N_{1}=\frac{1}{4}(1-r)(1-s) \\
& N_{2}=\frac{1}{4}(1+r)(1-s) \\
& N_{3}=\frac{1}{4}(1+r)(1+s) \\
& N_{4}=\frac{1}{4}(1-r)(1+s)
\end{aligned}
$$


Strain-displacement relationship can be written as (Cook et al., 2002; Zienkewicz and Taylor, 1991):

$$
\begin{aligned}
& \varepsilon_{x x}=\frac{\partial u}{\partial x} \\
& \varepsilon_{y y}=\frac{\partial v}{\partial y} \\
& \gamma_{x y}=\frac{\partial u}{\partial y}+\frac{\partial v}{\partial x}
\end{aligned}
$$

Where,

$\varepsilon_{x x}=$ Normal strain along x-axis,

$\varepsilon_{y y}=$ Normal strain along y-axis, and

$\gamma_{x y}=$ Shear strain.

Substituting the expression in Equation (4.2) into Equation (4.5), the following relationship is obtained:

$$
\left\{\begin{array}{l}
\varepsilon_{x x} \\
\varepsilon_{y y} \\
\gamma_{x y}
\end{array}\right\}=\left[\begin{array}{cccccccc}
\frac{\partial N_{1}}{\partial x} & 0 & \frac{\partial N_{2}}{\partial x} & 0 & \frac{\partial N_{3}}{\partial x} & 0 & \frac{\partial N_{4}}{\partial x} & 0 \\
0 & \frac{\partial N_{1}}{\partial y} & 0 & \frac{\partial N_{2}}{\partial y} & 0 & \frac{\partial N_{3}}{\partial y} & 0 & \frac{\partial N_{4}}{\partial y} \\
\frac{\partial N_{1}}{\partial y} & \frac{\partial N_{1}}{\partial x} & \frac{\partial N_{2}}{\partial y} & \frac{\partial N_{2}}{\partial x} & \frac{\partial N_{3}}{\partial y} & \frac{\partial N_{3}}{\partial x} & \frac{\partial N_{4}}{\partial y} & \frac{\partial N_{4}}{\partial x}
\end{array}\right]\left\{\begin{array}{c}
u_{1} \\
u_{2} \\
u_{3} \\
u_{4} \\
v_{1} \\
v_{2} \\
v_{3} \\
v_{4}
\end{array}\right\}
$$

or

$\{\varepsilon\}=[B]\{q\}$

Here, the matrix [B] is called the strain-displacement transformation matrix. The relationship between stress and strain quantities is written as: 


$$
\left\{\begin{array}{l}
\sigma_{x x} \\
\sigma_{y y} \\
\tau_{x y}
\end{array}\right\}=\left[\begin{array}{lll}
C_{11} & C_{12} & C_{13} \\
C_{21} & C_{22} & C_{23} \\
C_{31} & C_{32} & C_{33}
\end{array}\right]\left\{\begin{array}{l}
\varepsilon_{x x} \\
\varepsilon_{y y} \\
\gamma_{x y}
\end{array}\right\}
$$

or

$$
\{\sigma\}=[C]\{\varepsilon\}
$$

Here, $\{\sigma\}$ is the vector of stress components and $[\mathrm{C}]$ is the constitutive matrix.

Element stiffness can be determined using the principal of minimum potential energy. The potential energy of a body can be expressed as the sum of the internal energy (strain energy) and the potential due to body forces and surface tractions. The following potential energy functional is used for the derivation of element stiffness matrix:

$$
\pi_{p}=\iiint_{V} U(u, v, w) d v-\iiint_{V}(\bar{X} u+\bar{Y} v+\bar{Z} w) d v-\iiint_{S_{1}}\left(\overline{T_{x}} u+\overline{T_{y}} v+\overline{T_{z}} w\right) d S-\sum\left(P_{i x} u_{i}+P_{i y} v_{i}\right)
$$

Where, $S_{1}$ is the portion of the surface of the body on which surface tractions are prescribed and $U(\mathrm{u}, \mathrm{v}, \mathrm{w})$ denotes the strain energy density. The next two integrals in Equation (4.8) represent the work done (hence the potential lost) by body forces, $\bar{X}, \bar{Y}$, $\bar{Z}$ and surface tractions $T_{x}, \overline{T_{y}}, \overline{T_{z}}$. The quantities $\mathrm{u}, \mathrm{v}$ and $\mathrm{w}$ are the displacements. The quantity $\mathrm{P}_{\mathrm{i}}$ denotes the point load acting at node "i". Considering the initial stress conditions, the potential energy can be written as follows:

$$
\begin{aligned}
& \pi_{p}=\frac{1}{2} \iiint_{V}\{q\}^{T}\{B\}^{T}[C]\{B\}\{q\} d v-\iiint_{V}\{q\}^{T}[N]^{T}\{\bar{X}\} d v-\iiint_{S_{1}}\{q\}^{T}[N]^{T}\{\bar{T}\} d S \\
& +\iiint_{V}\{q\}^{T}[B]^{T}\left\{\sigma_{o}\right\} d v-\sum\left(P_{i x} u_{i}+P_{i y} v_{i}\right)
\end{aligned}
$$


Where, $\left\{\sigma_{o}\right\}$ is the vector of initial stresses.

The element equilibrium equations can be found by minimizing the potential energy functional, $\pi_{p}$. The element equilibrium equations take the following form:

$$
[K]_{(6 \times 6)}\{q\}_{(6 \times 1)}=\{Q\}_{(6 \times 1)}
$$

Where, $[K]$ is the element stiffness matrix and $\{\mathrm{Q}\}$ is the element load vector. These can be expresses as:

$[\mathrm{K}]=\iiint_{V}\{B\}^{T}[C]\{B\} d v$

and

$$
\{Q\}=\iiint_{V}[N]^{T}\{\bar{X}\} d v+\iiint_{S_{1}}[N]^{T}\{\bar{T}\} d S-\iiint_{V}[B]^{T}\left\{\sigma_{o}\right\} d v+\{P\}
$$

\subsubsection{Three dimensional brick element formulation}

Let us consider an 8-node brick element with displacements $\mathrm{u}, \mathrm{v}$ and $\mathrm{w}$ at a given point (node) in the $\mathrm{x}, \mathrm{y}$ and $\mathrm{z}$ direction as shown in Figure 4.4.

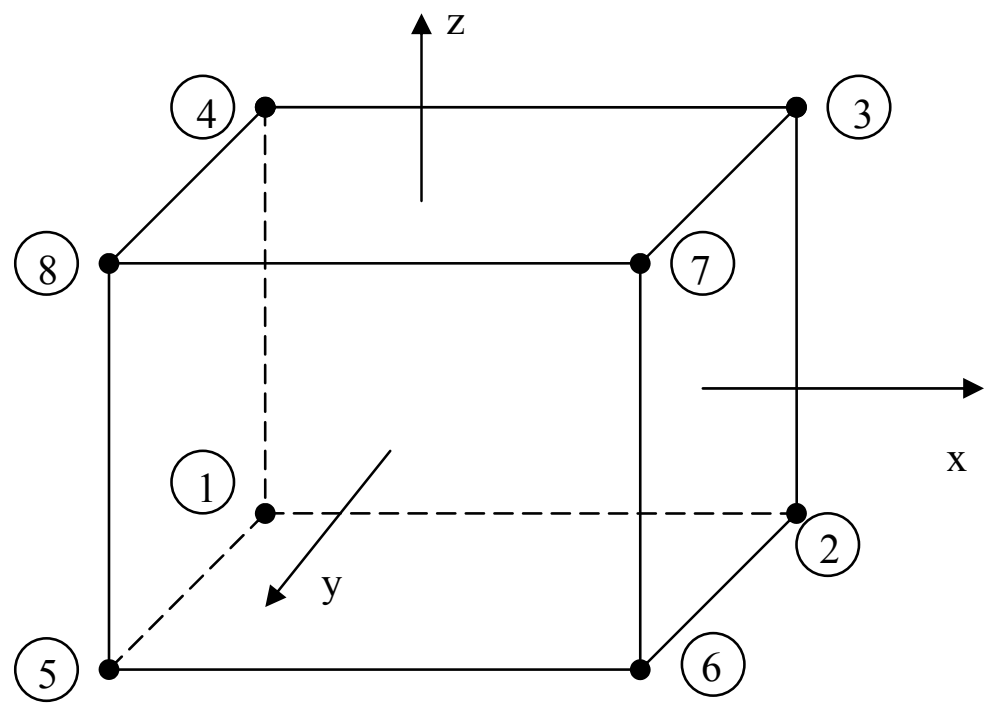

Figure 4.4: Nodal displacements along $x$ and $y$ directions for solid element 
The displacements $\mathrm{u}, \mathrm{v}$ and $\mathrm{w}$ can be expressed by using interpolation functions and nodal displacements as follows:

$$
\begin{aligned}
& \mathrm{u}=\mathrm{N}_{1} \mathrm{u}_{1}+\mathrm{N}_{2} \mathrm{u}_{2}+\mathrm{N}_{3} \mathrm{u}_{3}+\mathrm{N}_{4} \mathrm{u}_{4}+\ldots \ldots . .+\mathrm{N}_{8} \mathrm{u}_{8} \\
& \mathrm{v}=\mathrm{N}_{1} \mathrm{v}_{1}+\mathrm{N}_{2} \mathrm{v}_{2}+\mathrm{N}_{3} \mathrm{v}_{3}+\mathrm{N}_{4} \mathrm{v}_{4}+\ldots \ldots \ldots+\mathrm{N}_{8} \mathrm{v}_{8} \\
& \mathrm{w}=\mathrm{N}_{1} \mathrm{w}_{1}+\mathrm{N}_{2} \mathrm{~W}_{2}+\mathrm{N}_{3} \mathrm{w}_{3}+\mathrm{N}_{4} \mathrm{~W}_{4}+\ldots \ldots \ldots+\mathrm{N}_{8} \mathrm{~W}_{8}
\end{aligned}
$$

Where, $\mathrm{N}_{1}, \mathrm{~N}_{2}, \mathrm{~N}_{3}, \mathrm{~N}_{4} \ldots \ldots . . . \mathrm{N}_{8}$ are interpolation functions in local coordinates.

The interpolation function can be written as:

$$
N_{i}=\frac{1}{4}\left(1+r r_{i}\right)\left(1+s s_{i}\right)\left(1+t t_{i}\right)
$$

Where, $\mathrm{r}, \mathrm{s}$ and $\mathrm{t}$ correspond to the local coordinates which vary from -1 to +1 , and the subscript " $i$ " denotes the node number. For a solid element the interpolation functions at each node are given as:

$$
\begin{aligned}
& N_{1}=\frac{1}{8}(1-r)(1-s)(1-t) \\
& N_{2}=\frac{1}{8}(1+r)(1-s)(1-t) \\
& N_{3}=\frac{1}{8}(1+r)(1+s)(1-t) \\
& N_{4}=\frac{1}{8}(1-r)(1+s)(1-t) \\
& N_{5}=\frac{1}{8}(1-r)(1-s)(1+t) \\
& N_{6}=\frac{1}{8}(1+r)(1-s)(1+t) \\
& N_{7}=\frac{1}{8}(1+r)(1+s)(1+t) \\
& N_{8}=\frac{1}{8}(1-r)(1+s)(1+t)
\end{aligned}
$$


The strains $\varepsilon_{\mathrm{xx}}, \varepsilon_{\mathrm{yy}}, \varepsilon_{\mathrm{zz}}, \gamma_{\mathrm{xy}}, \gamma_{\mathrm{yz}}$ and $\gamma_{\mathrm{zx}}$ can be written as (Zienkiewicz and Taylor, 1991):

$$
\begin{aligned}
& \varepsilon_{x x}=\frac{\partial u}{\partial x} \\
& \varepsilon_{y y}=\frac{\partial v}{\partial y} \\
& \varepsilon_{z z}=\frac{\partial w}{\partial z} \\
& \gamma_{x y}=\frac{\partial u}{\partial y}+\frac{\partial v}{\partial x} \\
& \gamma_{y z}=\frac{\partial v}{\partial z}+\frac{\partial w}{\partial y} \\
& \gamma_{z x}=\frac{\partial w}{\partial x}+\frac{\partial u}{\partial z}
\end{aligned}
$$

Substituting the expression in Equation (4.12) into Equation (4.14), the following relationship is obtained:

$$
\{\varepsilon\}_{(6 \times 1)}=[B]_{(6 \times 24)}\{q\}_{(24 \times 1)}
$$

Where, [B] is the strain-displacement transformation matrix (Cook et al., 2002; Zienkewicz and Taylor, 1991).

The stress-strain relation for three dimensional case is given as:

$$
\left\{\begin{array}{c}
\sigma_{x x} \\
\sigma_{y y} \\
\sigma_{z z} \\
\tau_{x y} \\
\tau_{y z} \\
\tau_{z x}
\end{array}\right\}_{(6 x 1)}=[C]_{(6 z 6)}\left\{\begin{array}{l}
\varepsilon_{x x} \\
\varepsilon_{y y} \\
\varepsilon_{z z} \\
\gamma_{x y} \\
\gamma_{y z} \\
\gamma_{z x}
\end{array}\right\}_{(6 x 1)}
$$

or

$$
\{\sigma\}=[C]\{\varepsilon\}
$$

Here, $\{\sigma\}$ is the vector of stress components and $[\mathrm{C}]$ is the constitutive matrix. 
The element equilibrium equations are given as:

$$
[K]\{q\}=\{Q\}
$$

Where, $[\mathrm{K}]$ is the element stiffness matrix and $\{\mathrm{Q}\}$ is the element load vector. These can be expressed as:

$$
\begin{aligned}
& {[\mathrm{K}]=\iiint_{V}\{B\}_{(24 \times 6)}{ }^{T}[C]_{(6 \times 6)}\{B\}_{(6 \times 24)} d v} \\
& \{Q\}=\iiint_{V}[N]^{T}\{\bar{X}\} d v+\iiint_{S}[N]^{T}\{\bar{T}\} d S-\iiint_{V}[B]^{T}\left\{\sigma_{o}\right\} d v+\{P\}
\end{aligned}
$$

The element stiffness matrix $[\mathrm{K}]$ is a function of structural geometry, the element dimensions, and the material properties of the elements. For a buried pipe analysis, this stiffness matrix is composed of several element properties (soil element properties, backfill element properties and pipe properties). Two most important constitutive models used for buried pipe analysis are: (1) a soil model (Duncan and Chang, 1970; Desai and Siriwardane, 1984) and (2) a pipe model (Moser, 1990).

\subsection{Constitutive model}

Beam or plane strain elements are commonly used to discritize the pipe in twodimensional stress analysis. Solid elements are used in three-dimensional stress analysis. Plane strain elements were used for two-dimensional analysis and solid elements were used for three-dimensional analysis of buried HDPE pipes presented in this report. Any long structure whose geometry does not vary significantly in the longitudinal direction can be idealized as a plane strain problem. The constitutive equations for elastic, isotropic materials for plane strain conditions are given as (Desai and Siriwardane, 1984):

$$
\left\{\begin{array}{c}
\sigma_{x x} \\
\sigma_{y y} \\
\tau_{x y}
\end{array}\right\}=\frac{E}{(1+v)(1-2 v)}\left[\begin{array}{ccc}
1-v & v & 0 \\
v & 1-v & 0 \\
0 & 0 & \frac{1-2 v}{2}
\end{array}\right]\left\{\begin{array}{l}
\varepsilon_{x x} \\
\varepsilon_{y y} \\
\gamma_{x y}
\end{array}\right\}
$$

Where,

$\mathrm{E}=$ Young's modulus

$v=$ Poisson's ratio 
$\sigma_{x x}=$ Normal stress along x-axis

$\sigma_{y y}=$ Normal stress along y-axis

$\varepsilon_{x x}=$ Normal strain along x-axis

$\varepsilon_{y y}=$ Normal strain along y-axis

$\tau_{x y}=$ Shear Stress

$\gamma_{x y}=$ Shear strain

The solid elements were used in the three dimensional FE analysis of buried pipes. The library of solid elements includes first-order and second-order tetrahedral and brick elements. The most general constitutive relation for elastic solid elements is given below (Desai and Siriwardane, 1984).

$$
\left\{\begin{array}{l}
\sigma_{x x} \\
\sigma_{y y} \\
\sigma_{z z} \\
\tau_{x y} \\
\tau_{y z} \\
\tau_{z x}
\end{array}\right\}=\frac{E}{(1+v)(1-2 v)}\left[\begin{array}{cccccc}
1-v & v & v & 0 & 0 & 0 \\
v & 1-v & v & 0 & 0 & 0 \\
v & v & 1-v & 0 & 0 & 0 \\
0 & 0 & 0 & \frac{1-2 v}{2} & 0 & 0 \\
0 & 0 & 0 & 0 & \frac{1-2 v}{2} & 0 \\
0 & 0 & 0 & 0 & 0 & \frac{1-2 v}{2}
\end{array}\right]\left\{\begin{array}{l}
\varepsilon_{x x} \\
\varepsilon_{y y} \\
\varepsilon_{z z} \\
\gamma_{x y} \\
\gamma_{y z} \\
\gamma_{z x}
\end{array}\right\}
$$

Where,

$\mathrm{E}=$ Young's modulus

$v=$ Poisson's ratio

$\sigma_{x x}=$ Normal stress along $\mathrm{x}$-axis

$\sigma_{y y}=$ Normal stress along y-axis

$\sigma_{z z}=$ Normal stress along z-axis

$\varepsilon_{x x}=$ Normal strain along x-axis

$\varepsilon_{y y}=$ Normal strain along y-axis 
$\varepsilon_{z z}=$ Normal strain along z-axis

$\tau_{x y}=$ Shear Stress along xy-plane

$\tau_{y z}=$ Shear Stress along yz-plane

$\tau_{z x}=$ Shear Stress along zx-plane

$\gamma_{x y}=$ Shear strain along xy-plane

$\gamma_{y z}=$ Shear strain along yz-plane

$\gamma_{z x}=$ Shear strain along zx-plane

\subsection{Finite element computer program}

The main objective of this research work was to find the influence of trench width on the long-term structural performance of HDPE buried pipes by using the finite element analysis. The steps involved in the finite element analysis are shown in Figure 4.5. The finite element analysis comprises of pre-processing of data, solving governing equations and post-processing of results. The pre-processing comprises of modeling, meshing, constraining, and loading. The post-processing comprises of interpretation of results. Major part of the pre-processing and post-processing of data in this study was done by using a commercial finite element package (FEMAP, 2004).

FEMAP is a finite element modeling software package for performing preprocessing and post-processing of data for a variety of engineering analyses. FEMAP can be used to generate geometry, mesh the geometry, apply loads and boundary conditions. It also has the capability to export input data files compatible with over 20 finite element codes. FEMAP also provides extensive tools for checking the accuracy of the model before performing the finite element analysis. It can also check for coincident geometry, improper connections and compute cross sectional properties. FEMAP also serves as a postprocessor of results obtained from over 20 popular finite element codes. It has powerful visualization tools that enable the user to quickly interpret results (FEMAP, 2004).

The finite element analysis was done by using ABAQUS computer code in this research (ABAQUS, 2004). ABAQUS is a powerful commercial engineering analysis program, based on the finite element method. It has been popular over many decades in solving problems ranging from simple linear analysis to the complex nonlinear analysis. It 
has an extensive element library that can model complicated geometries. It also has an extensive list of material models that can simulate most typical engineering materials such as metals, rubber, polymers, composites, concrete, foams, and geotechnical materials such as soils and rock. ABAQUS can be used to solve more than just structural (stress/displacement) problems. It has been used in a diverse range of engineering fields such as heat transfer, mass diffusion, soil mechanics, and piezoelectric analysis (ABAQUS, 2004). The ABAQUS suite consists of two core solvers: ABAQUS/STANDARD and ABAQUS/EXPLICIT. ABAQUS/STANDARD is a general purpose finite element program designed to simulate large scale, complex linear and highly non-linear problems. ABAQUS/EXPLICIT solver is used to perform transient dynamic and quasi-static analysis using an explicit approach (ABAQUS, 2004).

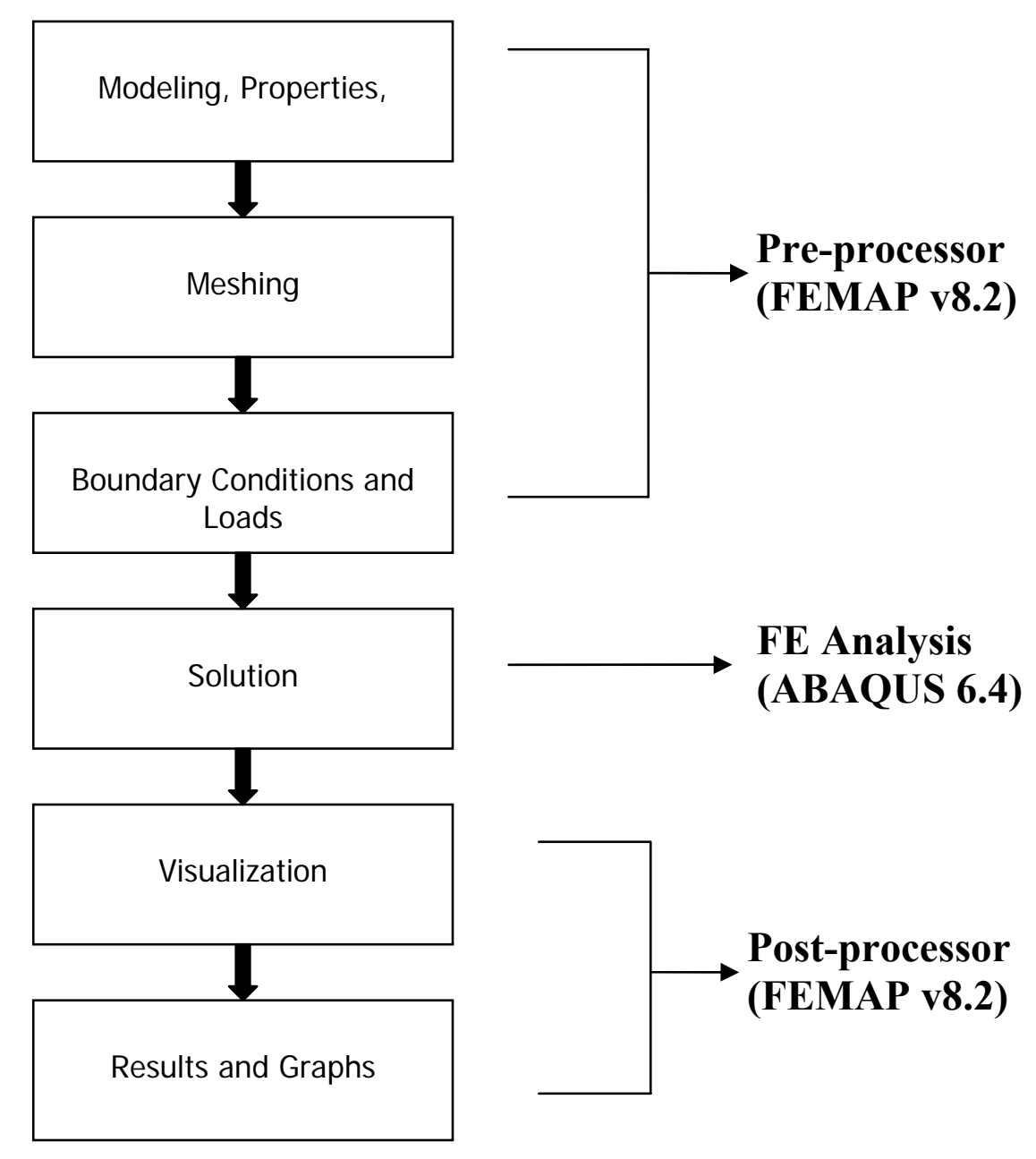

Figure 4.5: Steps involved in finite element analysis 


\subsection{Modeling of laboratory experiments}

Details of the laboratory tests on the performance of HDPE buried pipes conducted at West Virginia University are reported elsewhere (Simmons, 2002). The schematic diagram of the testing apparatus used in this study is shown in Figure 4.6. Twodimensional and three-dimensional models of the testing apparatus were developed using FEMAP. The sizes of the pipes tested were 6-inches $(15.2 \mathrm{~cm})$ and 8-inches $(20.3 \mathrm{~cm})$ in diameter. The size of the test box was: 40 inch (L) x 25 inch (W) x 20 inch (D) [102 cm (L) x $64 \mathrm{~cm}$ (W) x $51 \mathrm{~cm}$ (D)]. A uniform surcharge loading and a plate loading were considered in the study. Figure 4.7 and Figure 4.8 show the front view of the threedimensional finite element mesh used for surcharge and plate loadings. The applied surcharge load was varied as 10 psi (69 kpa), 20psi (138 kpa), and 30 psi (207 kpa). The applied plate load was varied as 1,000 lb (453.6 kg), 2,000 lb (907 kg) and 3,000 lb (1360 $\mathrm{kg})$. A 12 inch x 12 inch $(30.5 \mathrm{~cm} \mathrm{X} 30.5 \mathrm{~cm})$ plate was used to apply the point load. The thickness of the plate was 0.5 inch $(1.2 \mathrm{~cm})$.

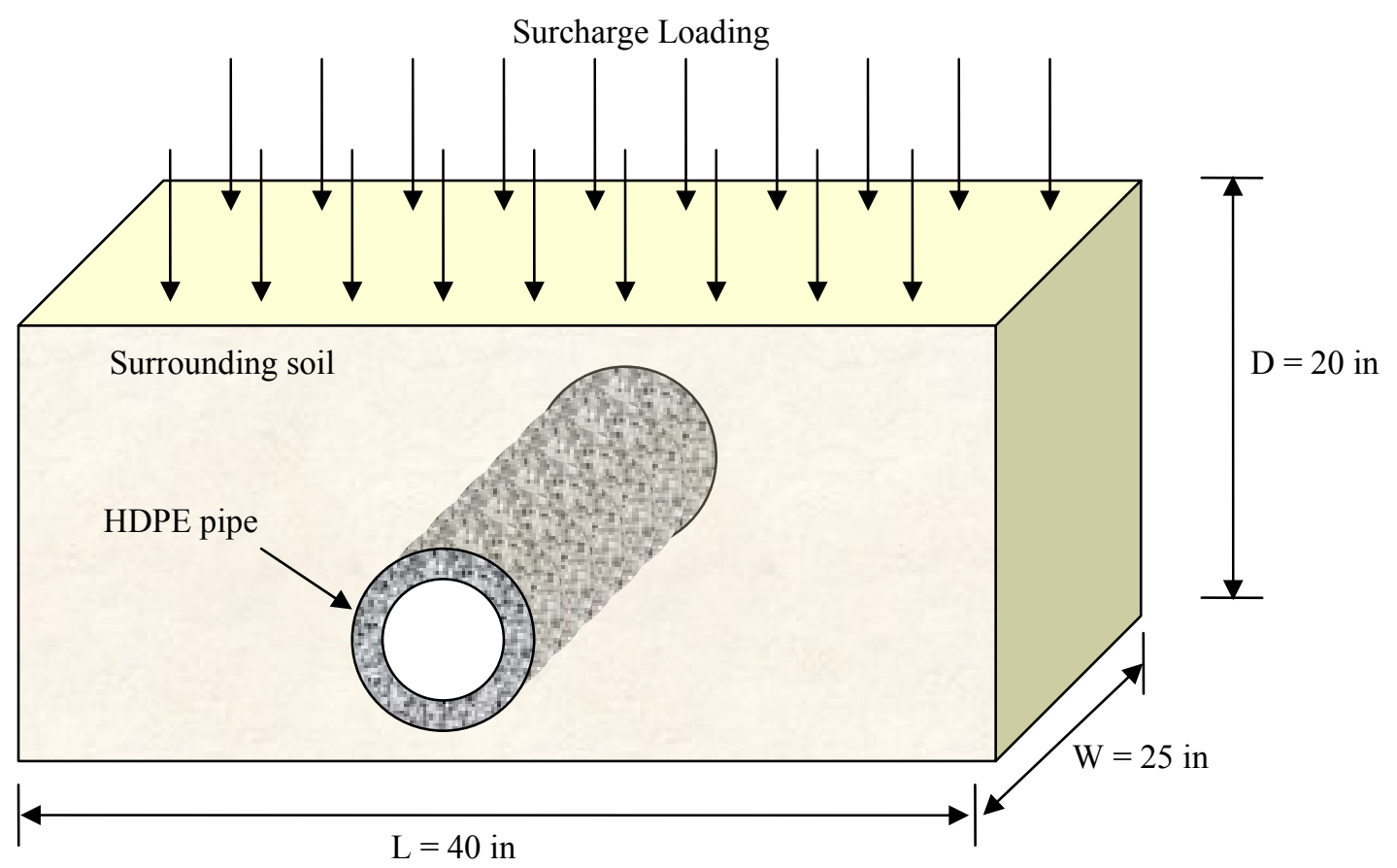

Figure 4.6: Schematic diagram of the testing apparatus 
Surcharge loading

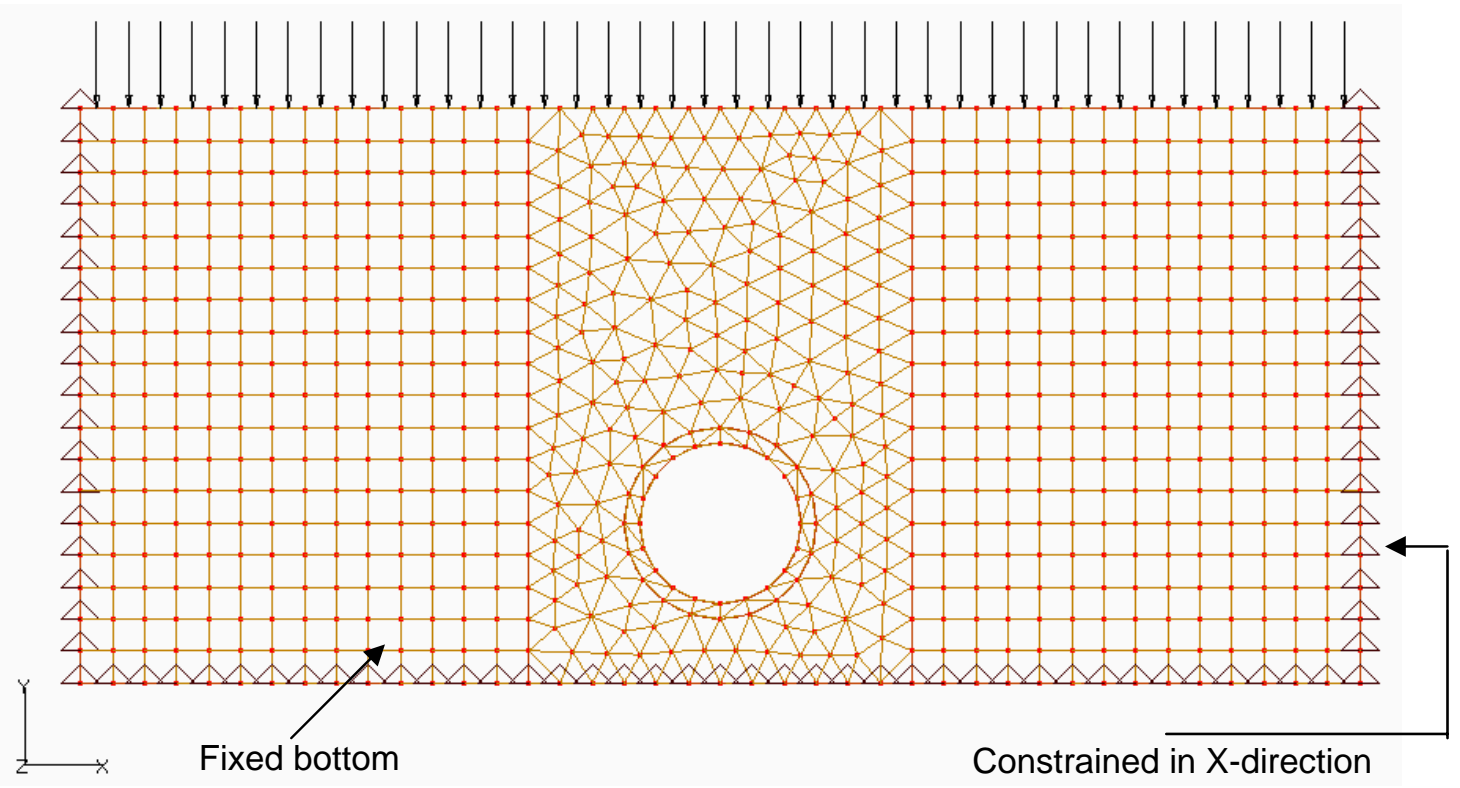

Figure 4.7: HDPE pipe model under uniform surcharge loading

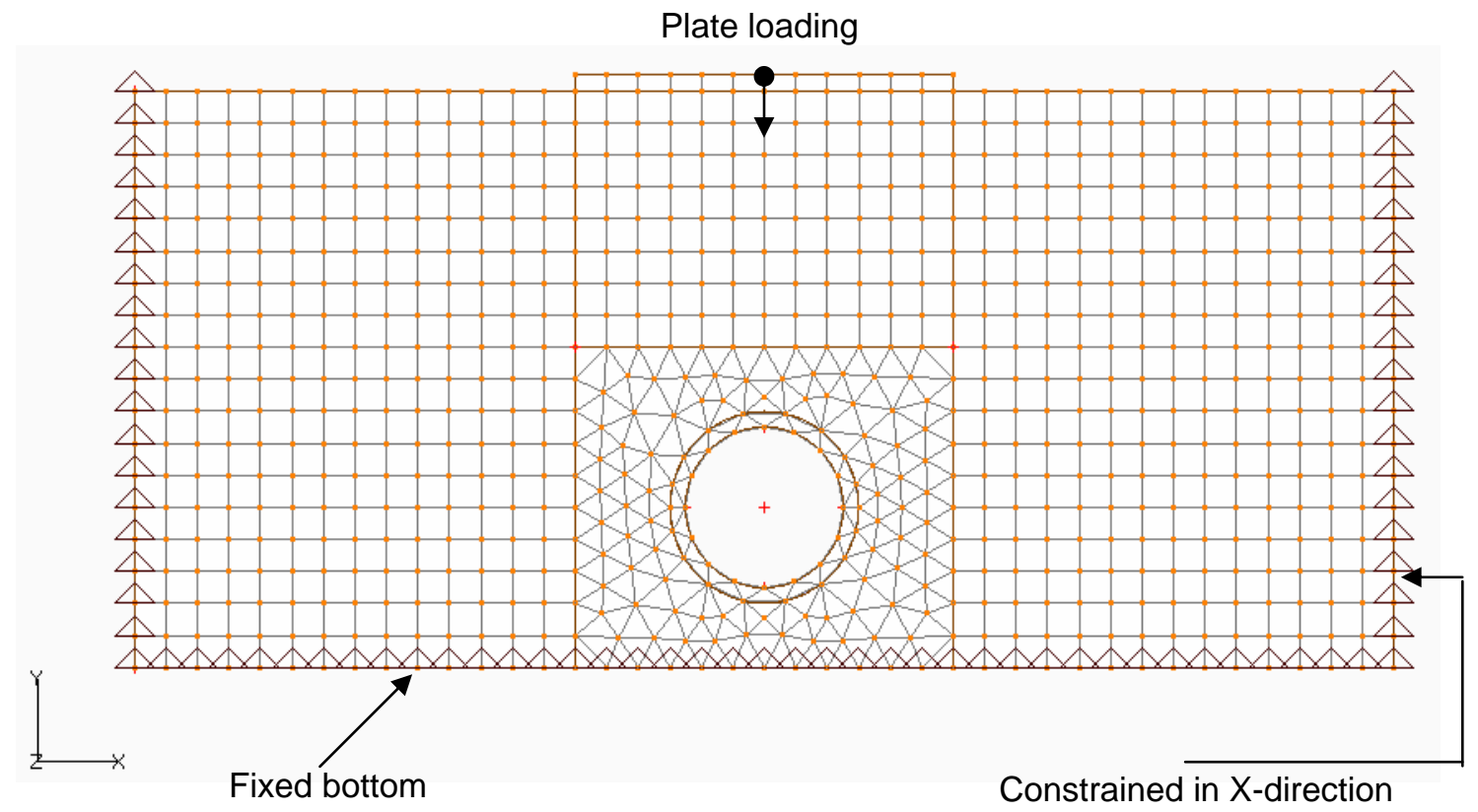

Figure 4.8: HDPE pipe model under plate loading 
The analysis of HDPE pipes requires its modulus of elasticity and the cross-sectional moment of inertia. Three parameters that are the most essential in the design of the analysis of flexible pipes are given below.

$>$ Load

$>$ Soil stiffness around the pipe

Pipe stiffness

The pipe stiffness is usually controlled by material properties of the pipe. The relationships related to pipe stiffness are given below (Moser, 1990).

$>$ Stiffness factor $=\mathrm{EI}$

$>$ Pipe stiffness $=\mathrm{F} / \Delta \mathrm{y}=6.7 \mathrm{EI} / \mathrm{r}^{3}$

$>$ Ring stiffness $=\mathrm{EI} / \mathrm{r}^{3}$

Where, $\mathrm{E}=$ modulus of elasticity of pipe material $\left(\mathrm{lb} / \mathrm{in}^{2}\right)$

$\mathrm{I}=$ moment of inertia of the wall cross-section per unit length of pipe $\left(\mathrm{in}^{4} / \mathrm{in}\right)$

$r=$ mean radius of pipe (in)

$\mathrm{F}=$ vertical force $(\mathrm{lb})$

$\Delta \mathrm{y}=$ vertical deflection (in)

For corrugated pipes, cross sectional moment of inertia per unit length (I) value was given in Table 3.10 in Chapter 3 of this report as provided by the pipe manufacturer. These specifications in general do not include the value of $\mathrm{E}$ (elastic modulus) of the pipe material. The procedure used in extracting the value of elastic modulus from reported data on pipes is described below. A typical cross-section of a pipe is shown below in Figure 4.9

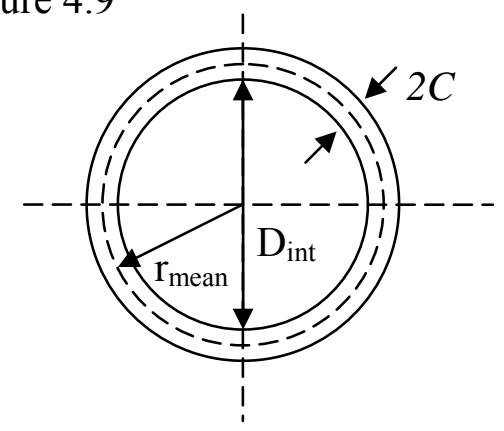

$$
\begin{aligned}
& \mathrm{C}=\text { Thickness } \\
& \mathrm{D}_{\text {int }}=\text { Inside diameter } \\
& \mathrm{r}_{\text {mean }}=\text { Mean pipe radius }
\end{aligned}
$$

Figure 4.9: Typical cross-section of a pipe 
The pipe stiffness can be expressed as (Moser, 1990):

$$
\mathrm{K}=6.7 \mathrm{EI} / \mathrm{r}^{3}
$$

Equation 4.16 can be written as:

$$
E=\frac{K r^{3}}{6.7 I}
$$

Where,

$\mathrm{E}=$ modulus of elasticity of pipe material

$\mathrm{r}=$ mean pipe radius (Given in Table 3.10)

$\mathrm{I}=$ Moment of inertia (Given in Table 3.10)

$\mathrm{K}=$ pipe stiffness (Given in Table 3.10)

Properties of a 6-inch HDPE pipe is given below (See Table 3.10)

Pipe stiffness $(\mathrm{K})=35 \mathrm{psi}$

Moment of inertia $(\mathrm{I})=0.0028 \mathrm{in}^{4} / \mathrm{in}$

$\mathrm{D}_{\text {mean }}=\mathrm{D}_{\text {int }}+2 \mathrm{C}=6.44$ in

$\mathrm{r}_{\text {mean }}=3.22 \mathrm{in}$

where,

$\mathrm{C}=$ thickness (Given in Table 3.10)

$\mathrm{D}_{\text {int }}=$ Inside diameter

$\mathrm{r}_{\text {mean }}=$ Mean pipe radius

Substituting these values in Equation 4.23, the elastic modulus can be obtained as:

$$
E=62287.77 \text { psi }
$$

Properties of a 8-inch HDPE pipe is given below (See Table 3.10)

Pipe stiffness $(\mathrm{K})=35 \mathrm{psi}$

Moment of inertia (I) $=0.0066 \mathrm{in}^{4} /$ in

$D_{\text {mean }}=D_{\text {int }}+2 \mathrm{C}=8.776$ in

$$
\mathrm{r}_{\text {mean }}=4.388 \text { in }
$$

where,

$\mathrm{C}=$ thickness (Given in Table 3.10)

$\mathrm{D}_{\text {int }}=$ Inside diameter 
$\mathrm{r}_{\text {mean }}=$ Mean pipe radius

Substituting these values in Equation 4.23, the elastic modulus can be obtained as:

$$
E=66872.74 \mathrm{psi}
$$

The modulus of elasticity thus obtained varies with the pipe diameter. Calculated modulus of elasticity, Poisson's ratio and mass density for 6-inch and 8-inch pipes are given in Table 4.1. Soil properties such as Young's modulus, Poisson's ratio and mass density for cohesive in-situ soil and loose in-situ soil are given in Table 4.2. Backfill properties such as Young's modulus, Poisson's ratio and mass density for high strength backfill and low strength backfill are given in Table 4.3. These values were back calculated from the laboratory experimental data as shown in Appendix C.

Table 4.1: Material properties for 6 inch and 8 inch diameter HDPE pipes

\begin{tabular}{|l|c|c|}
\hline Parameters & 6 inch HDPE pipe & 6 inch HDPE pipe \\
\hline Young's modulus (E) psi & 62287 & 66873 \\
\hline Poisson's ratio (v) & 0.25 & 0.25 \\
\hline Mass density $(\rho)^{*}$ pcf & 60 & 60 \\
\hline
\end{tabular}

* Reference (Plastic pipe institute (PPI), 2003)

Table 4.2: Material properties for cohesive and loose in-situ soil

\begin{tabular}{|l|c|c|c|c|c|c|}
\hline \multirow{2}{*}{ Parameters } & \multicolumn{3}{|c|}{ Cohesive In-Situ Soil } & \multicolumn{3}{c|}{ Loose In-Situ Soil } \\
\cline { 2 - 7 } & \multicolumn{2}{|c|}{ Trench width ratio } & \multicolumn{3}{c|}{ Trench width ratio } \\
\cline { 2 - 7 } & $\mathbf{1 . 5}$ & $\mathbf{2}$ & $\mathbf{2 . 5}$ & $\mathbf{1 . 5}$ & $\mathbf{2}$ & $\mathbf{2 . 5}$ \\
\hline Young's modulus (E) psi & 1000 & 2000 & 2000 & 400 & 600 & 1500 \\
\hline Poisson's ratio (v) & 0.3 & 0.3 & 0.3 & 0.3 & 0.3 & 0.3 \\
\hline Mass density $(\rho)^{* * *}$ pcf & 100 & 100 & 100 & 100 & 100 & 100 \\
\hline
\end{tabular}

** Reference (ASTM D2487) 
Table 4.3: Material properties for high strength and low strength backfill

\begin{tabular}{|c|c|c|c|c|c|c|}
\hline \multirow{2}{*}{ Parameters } & \multicolumn{3}{|c|}{ High strength backfill } & \multicolumn{3}{c|}{ Low strength backfill } \\
\cline { 2 - 7 } & \multicolumn{3}{|c|}{ Trench width ratio } & \multicolumn{3}{c|}{ Trench width ratio } \\
\cline { 2 - 7 } & $\mathbf{1 . 5}$ & $\mathbf{2}$ & $\mathbf{2 . 5}$ & $\mathbf{1 . 5}$ & $\mathbf{2}$ & $\mathbf{2 . 5}$ \\
\hline Young's modulus (E) psi & 1000 & 3000 & 6200 & 400 & 1700 & 2250 \\
\hline Poisson's ratio (v) & 0.3 & 0.3 & 0.3 & 0.3 & 0.3 & 0.3 \\
\hline Mass density $(\rho)^{* *}$ pcf & 150 & 150 & 150 & 150 & 150 & 150 \\
\hline
\end{tabular}

** Reference (ASTM D2487)

\subsection{Modeling of buried pipes under field conditions}

In this study, HDPE pipes buried at depths greater than 20 feet $(6.1 \mathrm{~m})$ were considered. Backfill cover was assumed as 1 foot $(0.3048 \mathrm{~m})$ above the pipe. A schematic diagram of the buried pipe model used in this study is shown in Figure 4.10. The pipes considered in the analysis were 18 inch $(45.7 \mathrm{~cm})$ and 24 inch $(61 \mathrm{~cm})$ in diameter as recommended by the West Virginia Department of Highways (WVDOH). The trench width to pipe diameter ratios were selected as $1.5,2$, and 2.5 for both pipes. The material properties of HDPE pipe, backfill material, and soil used in the analysis of buried pipes under field conditions are given in Table 4.4. The long-term viscoelastic behavior of HDPE pipe was approximated by a static analysis in which the Young's modulus of pipe material was reduced. The assumed elastic modulus (E) for HDPE pipes at 5 years and 50 years are given below:

$$
\begin{aligned}
& E_{5}=\frac{E_{0}}{1.4} \\
& E_{50}=\frac{E_{0}}{2.64}
\end{aligned}
$$

Where,

$E_{0}=$ Young's modulus of HDPE pipe at 0 years

$E_{5}=$ Young's modulus of HDPE pipe at 5 years

$E_{50}=$ Young's modulus of HDPE pipe at 50 years 
Two-dimensional and three-dimensional finite element analyses were performed to simulate pipes under field conditions. For the three-dimensional analysis a cross sectional thickness of 100 foot $(30.5 \mathrm{~m})$ was considered as shown in Figure 4.11. Figure 4.12 shows the finite element mesh for the pipe subjected to an HS20 loading under field conditions.

\subsection{Summary of analyses}

Numerous analyses were performed with varied trench width ratios along with varied in-situ and backfill materials for 6-inch $(15.2 \mathrm{~cm})$ and 8-inch $(20.3 \mathrm{~cm})$ HDPE pipes. Details of the cases analyzed are shown in Figure 4.13. The details of the analysis of 18inch $(45.7 \mathrm{~cm})$ and 24-inch $(61 \mathrm{~cm})$ pipes are shown in Figure 4.14 . 

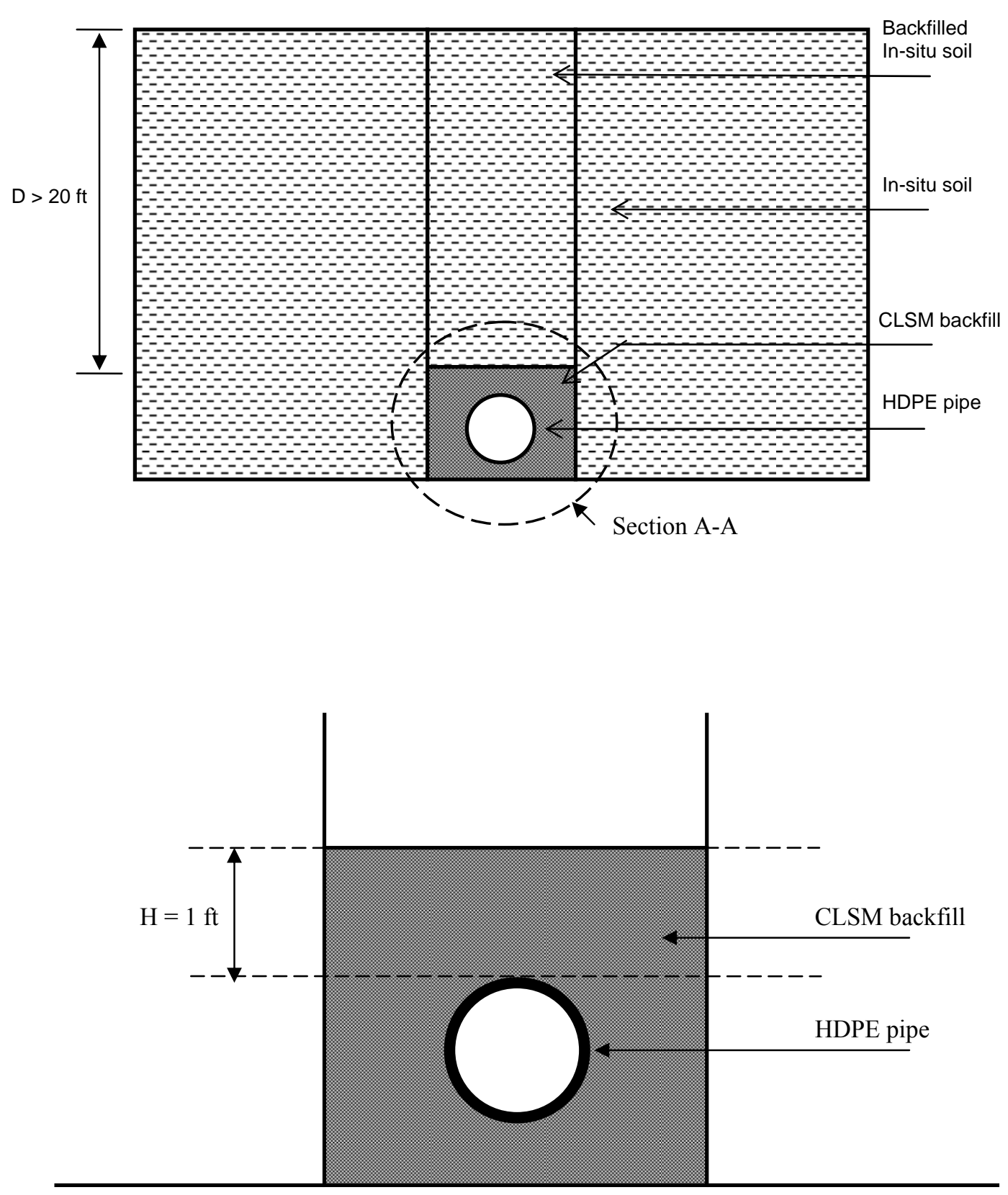

Section A-A

Figure 4.10: Schematic diagram of the finite element model under field conditions 


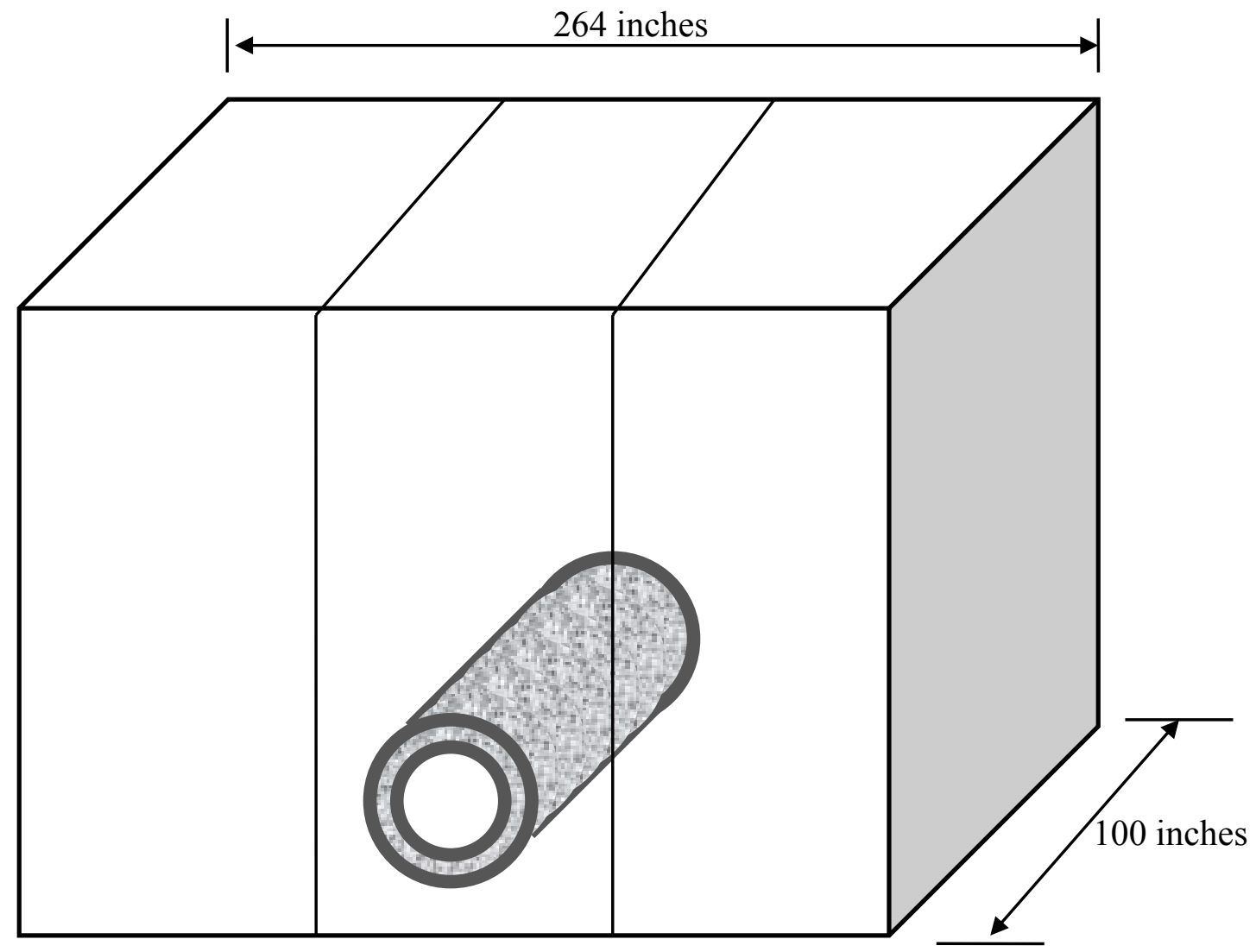

Figure 4.11: Schematic diagram of three dimensional finite element model under field conditions 


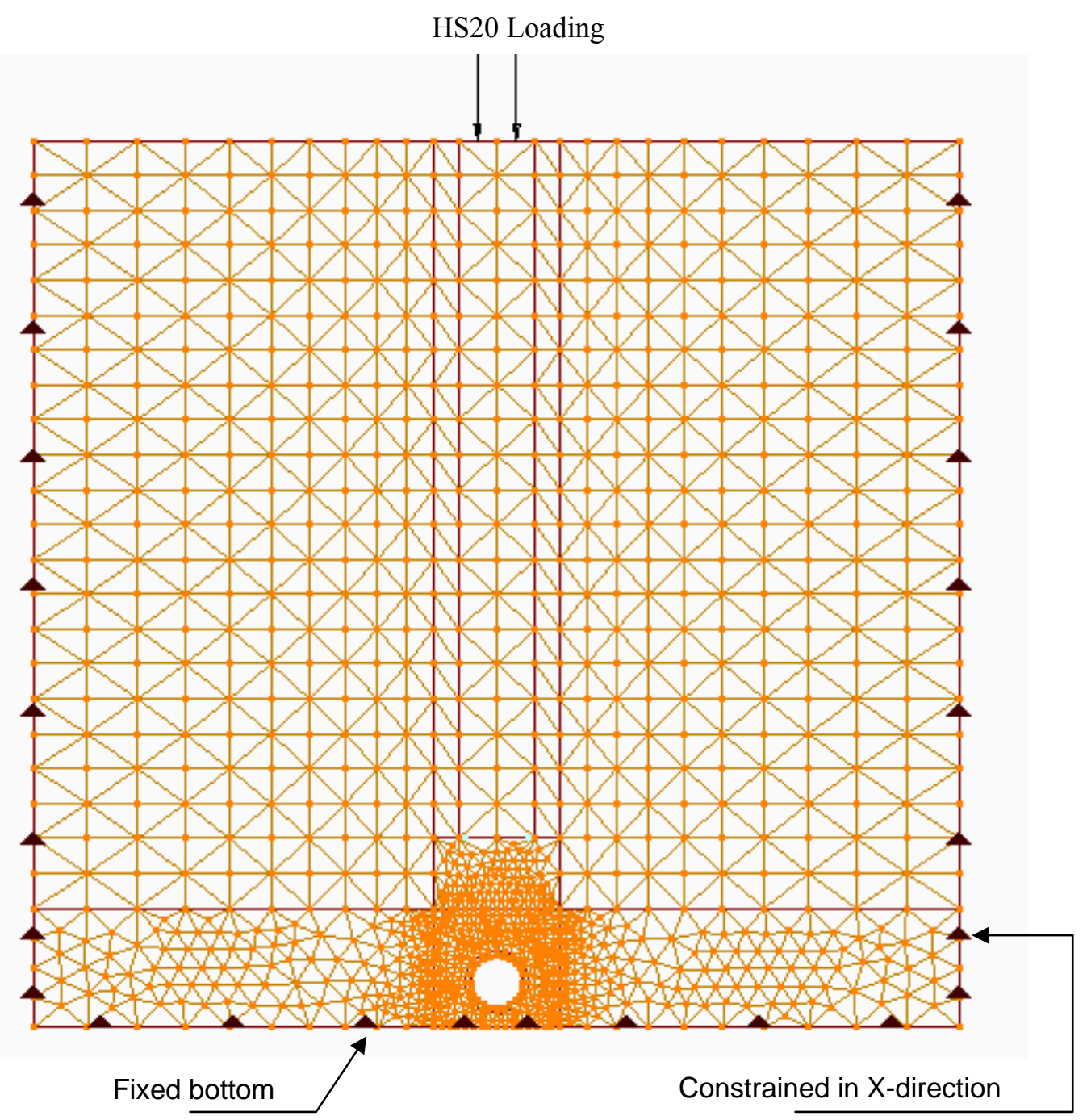

Figure 4.12: HDPE pipe model subjected to HS20 loading under field conditions 
Table 4.4: Material properties used for the analysis of a field configuration

\begin{tabular}{|c|c|c|c|c|c|c|c|c|}
\hline \multirow{2}{*}{ parameters } & \multirow{2}{*}{$\begin{array}{l}18 \text { inch } \\
\text { HDPE }\end{array}$} & \multirow{2}{*}{$\begin{array}{l}24 \text { inch } \\
\text { HDPE }\end{array}$} & \multicolumn{2}{|c|}{18 inch HDPE } & \multicolumn{2}{|c|}{ 24inch HDPE } & \multirow{2}{*}{$\begin{array}{l}\text { Backfill } \\
\text { material }\end{array}$} & \multirow{2}{*}{ In-situ soil } \\
\hline & & & 5 years & 50 years & 5 years & 50 years & & \\
\hline $\begin{array}{c}\text { Young's } \\
\text { modulus } \\
\text { (E) psi }\end{array}$ & 65312 & 77317 & 46651 & 13063 & 55226 & 15463 & 1000 & 420 \\
\hline $\begin{array}{l}\text { Poisson's } \\
\text { ratio (v) }\end{array}$ & 0.35 & 0.35 & 0.35 & 0.35 & 0.35 & 0.35 & 0.3 & 0.3 \\
\hline $\begin{array}{c}\text { Mass density } \\
\text { (р) pcf }\end{array}$ & 60 & 60 & 60 & 60 & 60 & 60 & 140 & 125 \\
\hline
\end{tabular}


PIPE ANALYSIS

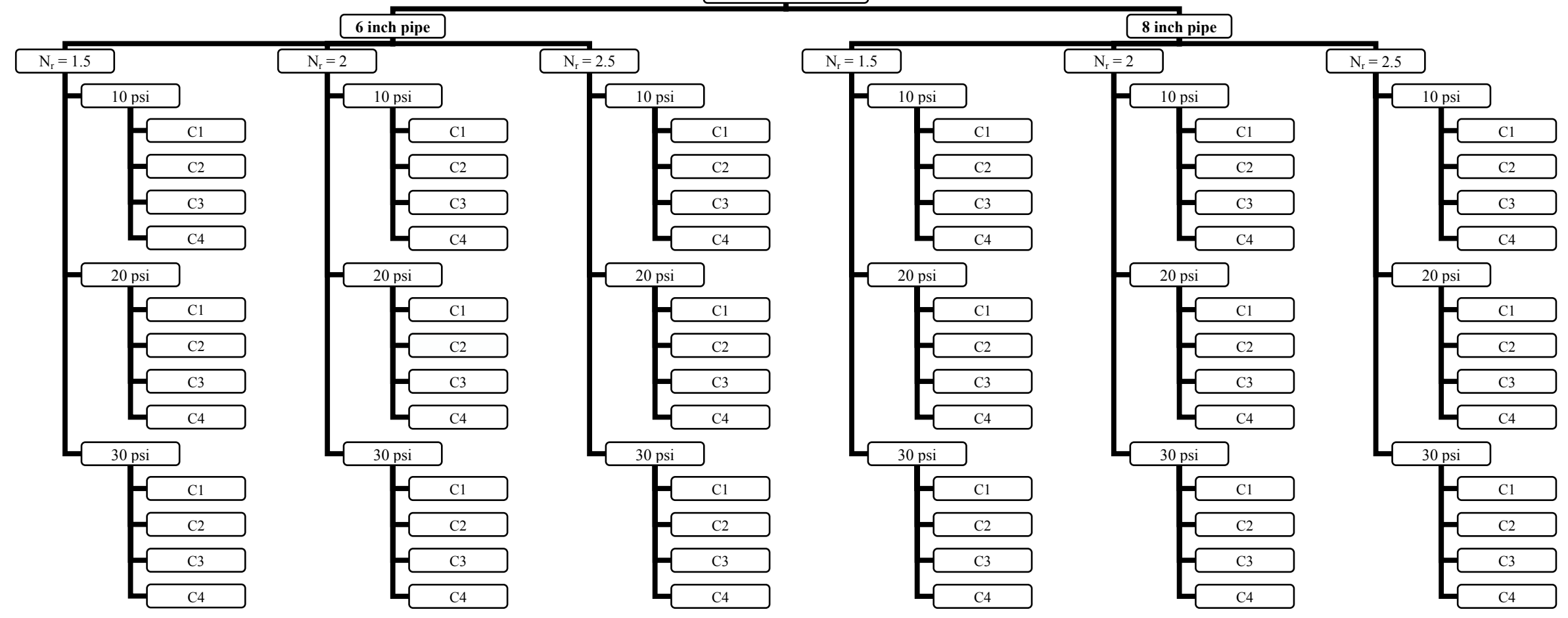

Figure 4.13: Pipe analysis layout for 6 inch and 8 inch HDPE pipes under Laboratory conditions 


\section{Where,}

$\mathrm{N}_{\mathrm{r}}=$ Trench width to pipe diameter ratio.

$\mathrm{C} 1=$ Cohesive In-Situ Soil with Low strength backfill.

$\mathrm{C} 2=$ Cohesive In-Situ Soil with High strength backfill.

C3 = Loose In-Situ Soil with Low strength backfill.

C4 = Loose In-Situ Soil with High strength backfill. 


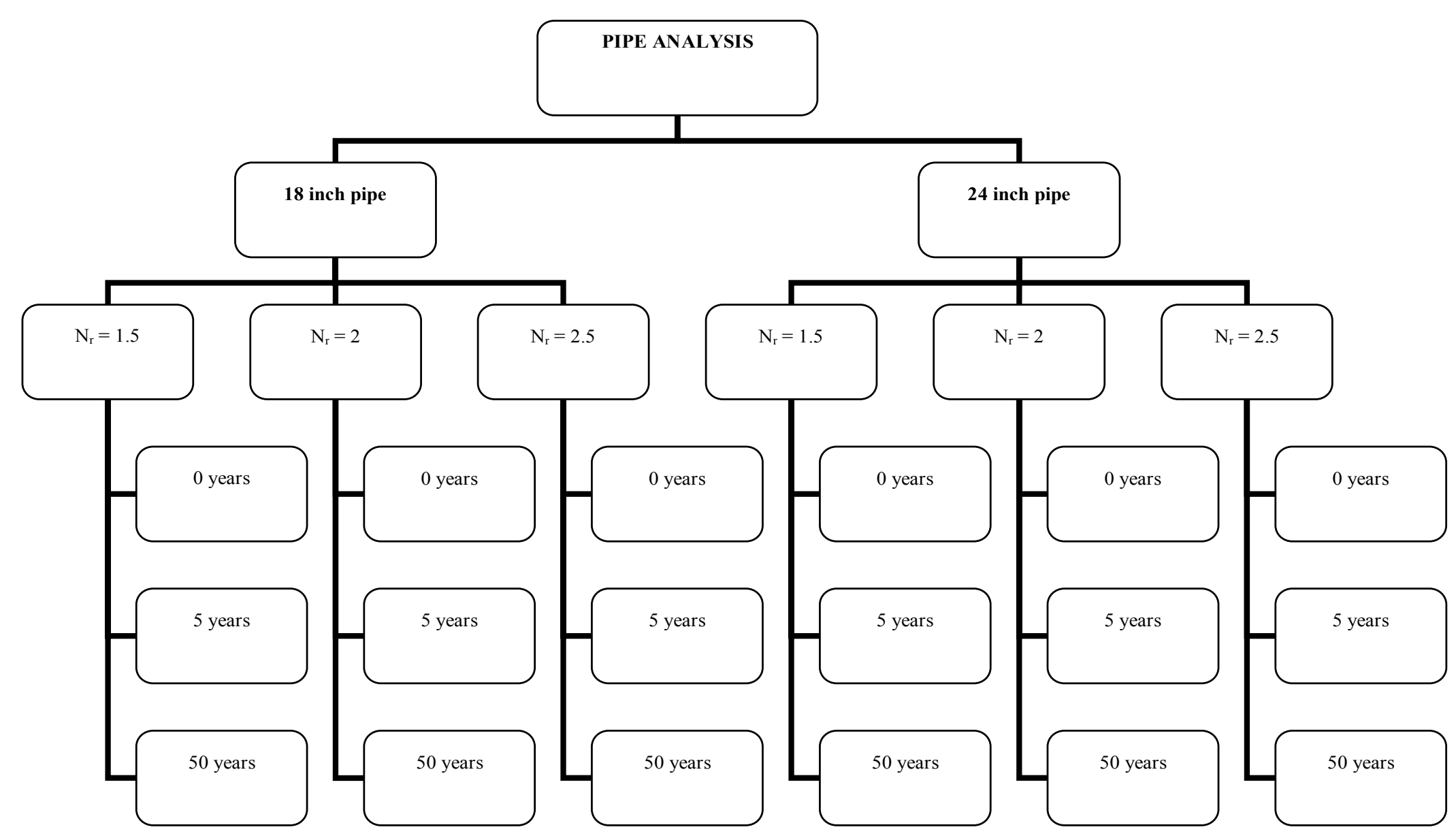

Where $\mathrm{N}_{\mathrm{r}}=$ Trench width to pipe diameter ratio.

Figure 4.14: Pipe analysis layout for 18 inch and 24 inch HDPE pipes under Field conditions 


\section{CHAPTER 5}

\section{NUMERICAL RESULTS UNDER LABORATORY CONDITIONS}

\subsection{Introduction}

The primary objective of this research is to find the influence of the trench width on the overall performance of buried pipes. Results from the finite element analysis of buried pipes are presented and compared with that of the experimental data from laboratory tests. The control variables in this experiment are: pipe diameter $(\mathrm{d})$, trench width ratio $\left(\mathrm{N}_{\mathrm{r}}\right)$, insitu soil strength, CLSM strength, and external loading. The trench width ratio $\left(\mathrm{N}_{\mathrm{r}}\right)$ is defined as the ratio of trench width divided by the pipe diameter. The dependent variables are the pipe deflections and the soil stresses. Since all tests were done with the same type of pipe, the pipe stiffness was a constant for any given pipe diameter. The trench width was varied by at least three values for every test configuration. The experimental program (Simmons, 2002) as well as the finite element analysis included trench width ratios of 1.5, 2.0, and 2.5. The graphs relating trench width ratio and pipe deflections are presented in more detail in the following sections. These data show a tendency for larger trench widths to reduce the deflections in the pipe. The pipe diameter was varied by two values: 6-inch $(15.2 \mathrm{~cm})$ and 8 -inch $(20.3 \mathrm{~cm})$. A comparison of performance of these pipes is useful in predicting the performance of other pipes.

Experiments were conducted by using different trench width ratios, backfill materials, and insitu soils. The CLSM mixtures tested in this research included a WVDOT class A mixture with a compressive strength of $280 \mathrm{psi}(1,930 \mathrm{kPa})$ and a WVDOT class C mixture with a compressive strength of $1,150 \mathrm{psi}(7,929 \mathrm{kPa})$. The class A CLSM is considered as a low strength material while the class C CLSM is considered as a high strength material. Two types of insitu soils were used: a low strength soil whose strength varied from $400 \mathrm{psi}(2,758 \mathrm{kPa})$ to $1,500 \mathrm{psi}(10,342 \mathrm{kPa})$, and a high strength soil whose strength varied from $800 \mathrm{psi}(5,516 \mathrm{kPa})$ to $2,000 \mathrm{psi}(13,789 \mathrm{kPa})$. Two types of loading cases were considered in the experiments. One with an uniform surcharge load and the other with a plate load acting along the centerline of the pipe. The schematic diagrams of the loading configurations are shown in the Figure 5.1 and Figure 5.2. The details of the cases considered in this study were presented in Figure 4.13 in chapter 4. 


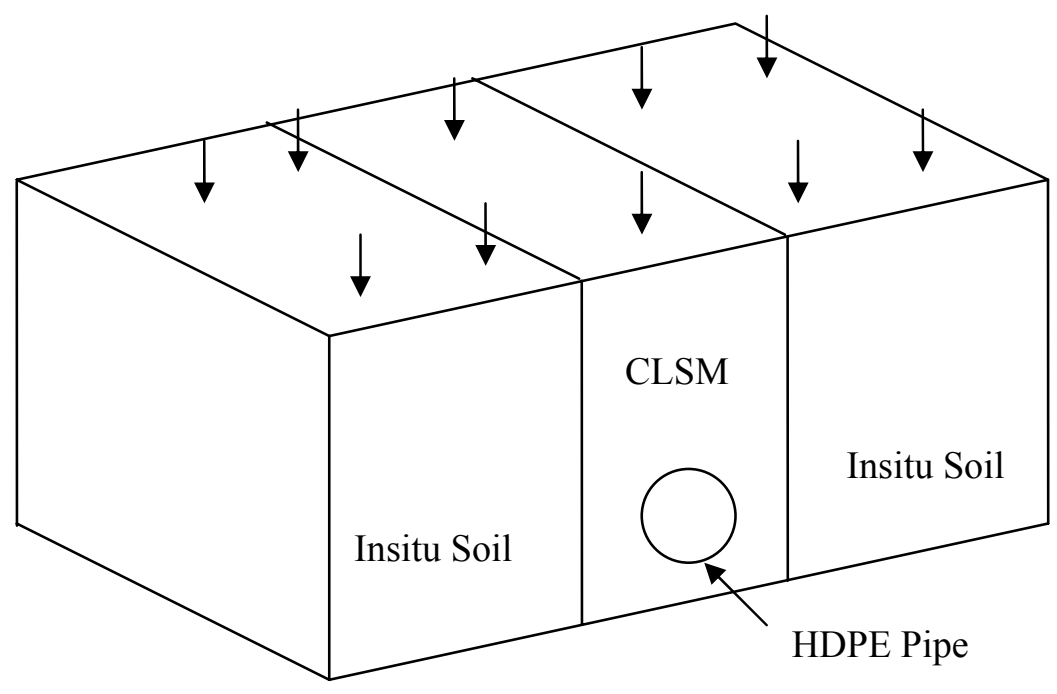

Figure 5.1: Schematic diagram of HDPE pipe under surcharge loading

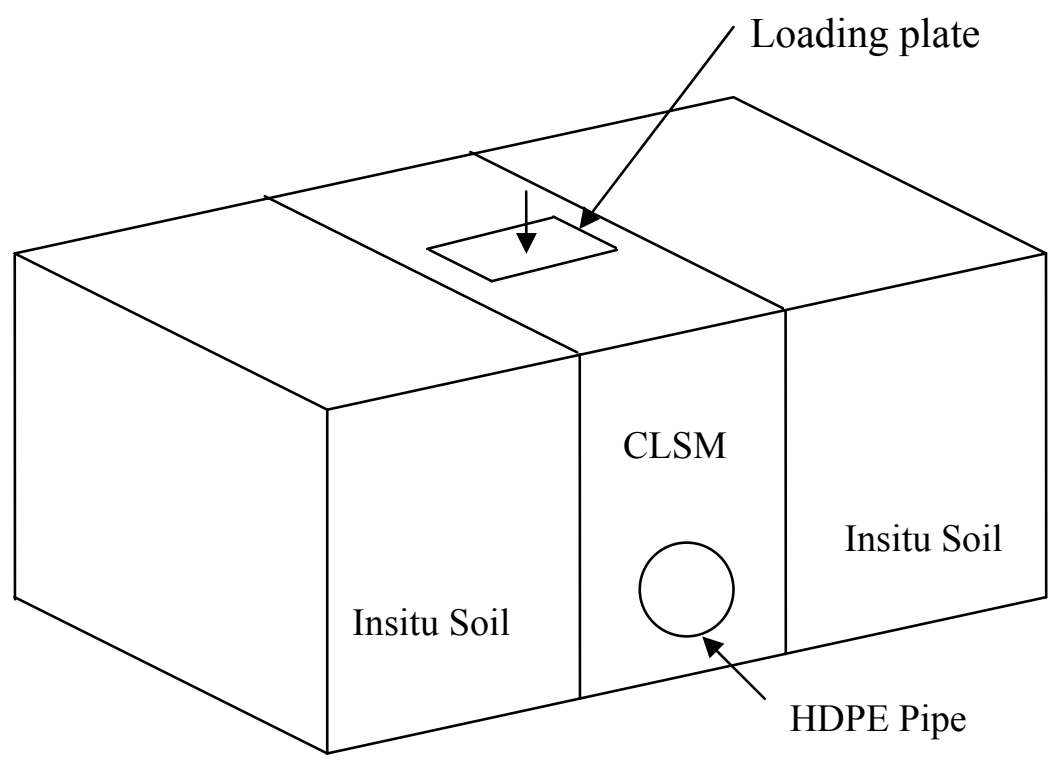

Figure 5.2: Schematic diagram of HDPE pipe under plate loading 


\subsection{Pipe deflections due to surcharge loading}

Figures 5.3 to 5.5 show pipe deflections for a surcharge loading of 10 psi $(69 \mathrm{kPa})$, 20 psi $(138 \mathrm{kPa})$ and $30 \mathrm{psi}(207 \mathrm{kPa})$. In these figures, deflections are presented as a function of the trench width ratio $\left(\mathrm{N}_{\mathrm{r}}\right)$. The trench width ratio $\left(\mathrm{N}_{\mathrm{r}}\right)$ is defined as the trench width divided by the pipe diameter. Tables A1 to A3 in Appendix A show the numerical values of maximum pipe deflection under these loading conditions. From the preceding graphs several conclusions can be drawn about the relationships between the variables. The graphs show that the pipe deflections decrease with an increase in the trench width ratio $(\mathrm{Nr})$.

Figure 5.3 presents the deflections of a 6 -inch $(15.2 \mathrm{~cm})$ buried pipe under uniform surcharge loading in cohesive in-situ soil with low strength backfill material. The results indicate that the finite element predictions are much stiffer compared to that of the experimental data. Results obtained for the 6-inch $(15.2 \mathrm{~cm})$ pipe under cohesive in-situ soil with high strength backfill material are shown in Figure 5.4. The finite element results compare well with that of the experimental values at higher loading conditions [i.e., $\mathrm{P} \geq 20$ psi $(138 \mathrm{kPa})]$. For the 6-inch $(15.2 \mathrm{~cm})$ pipe under loose in-situ soil with low strength backfill material, the finite element results do not compare well with that of the experimental values as shown in Figure 5.5. However, the finite element results compare well with the experimental data at higher loading conditions for the 6-inch $(15.2 \mathrm{~cm})$ pipe under loose in-situ soil with high strength backfill material as shown in Figure 5.6. Table A5 in Appendix A shows pipe deflections relevant to Figure 5.6.

Comparisons of finite element results with experimental data for the 8-inch $(20.3$ $\mathrm{cm})$ HDPE pipe at various trench width ratios with different backfill and insitu soil materials are shown in Figures 5.7 to 5.10 and Tables A5 to A8 (in Appendix A). The finite element results for the 8 -inch $(20.3 \mathrm{~cm})$ pipe under cohesive insitu soil with low strength backfill material show that the pipe-soil system is much stiffer compared to that of the experimental values. Finite element results for the 8-inch $(20.3 \mathrm{~cm})$ pipe under cohesive insitu soil with high strength backfill material compared well with experimental data at higher loading conditions. The finite element values for the 8 -inch $(20.3 \mathrm{~cm})$ pipe under loose insitu soil with low strength backfill material do not compare well with the experimental data. The experimental results at higher loading conditions compared well 
with the finite element results for the 8 -inch $(20.3 \mathrm{~cm})$ pipe under loose insitu soil with high strength backfill material. With more testing of different pipe diameters a more reliable correlation between the trench width ratio $\left(\mathrm{N}_{\mathrm{r}}\right)$ and the pipe deflection can be obtained.

Figure 5.11 shows contours of pipe deflections for the 8-inch $(20.3 \mathrm{~cm})$ pipe under surcharge loading at the ground surface. The contour pattern shown in this figure is typical of deflections around buried pipes subject to surcharge loading. 

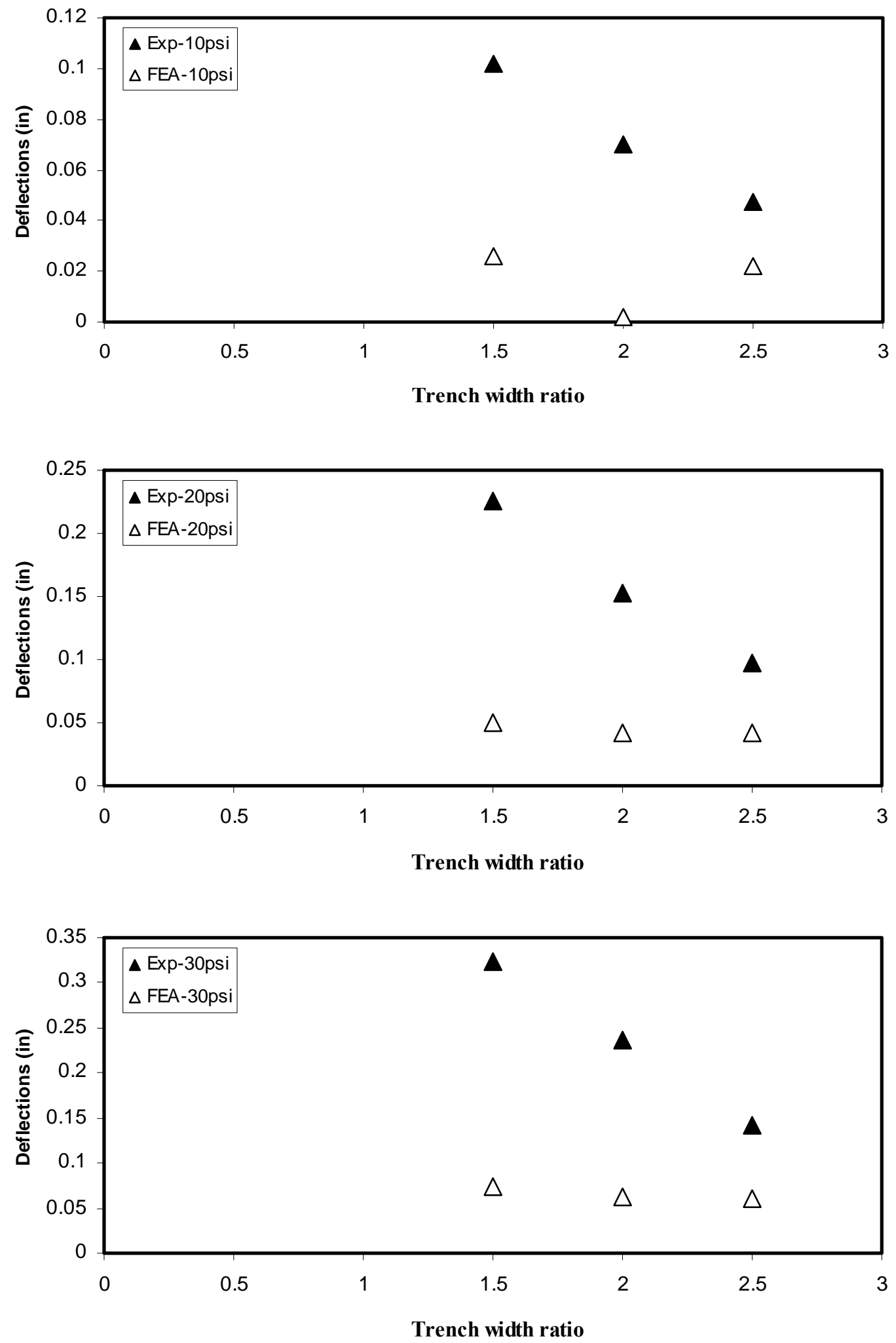

Figure 5.3: Pipe deflections under surcharge loading of the 6-inch pipe in cohesive insitu soil with low strength backfill 

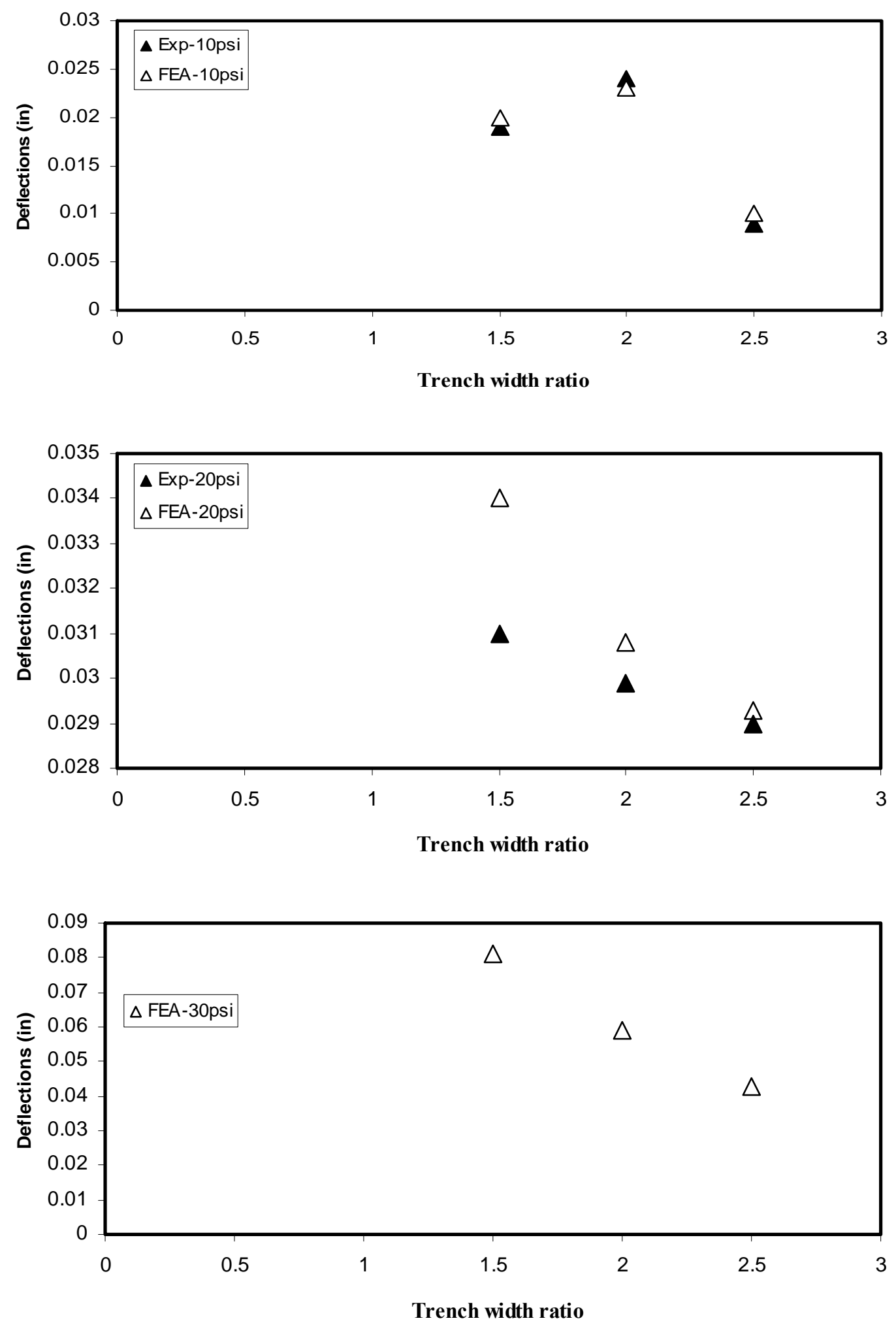

Figure 5.4: Pipe deflections under surcharge loading of the 6-inch pipe in cohesive insitu soil with high strength backfill 

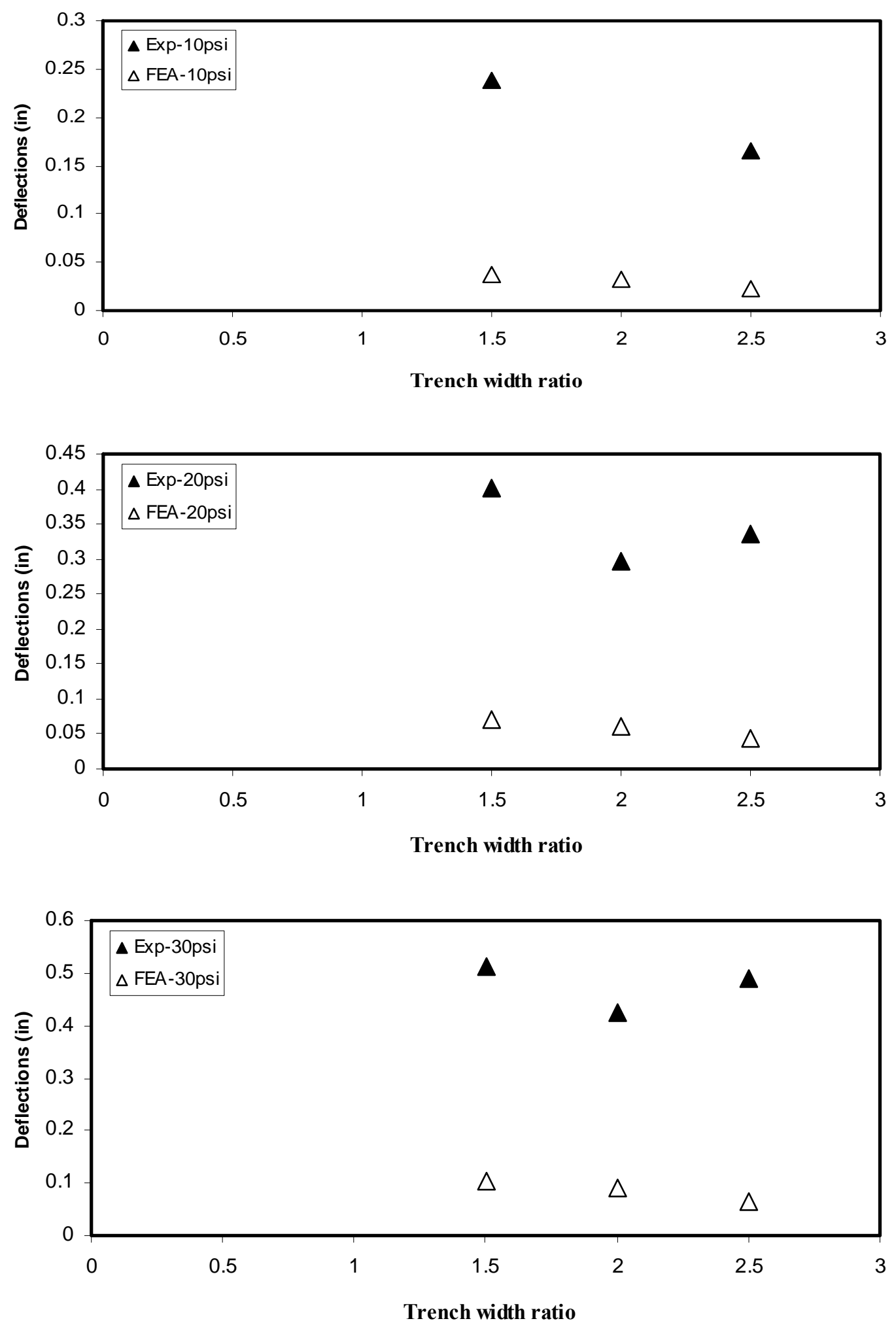

Figure 5.5: Pipe deflections under surcharge loading of the 6-inch pipe in loose insitu soil with low strength backfill 

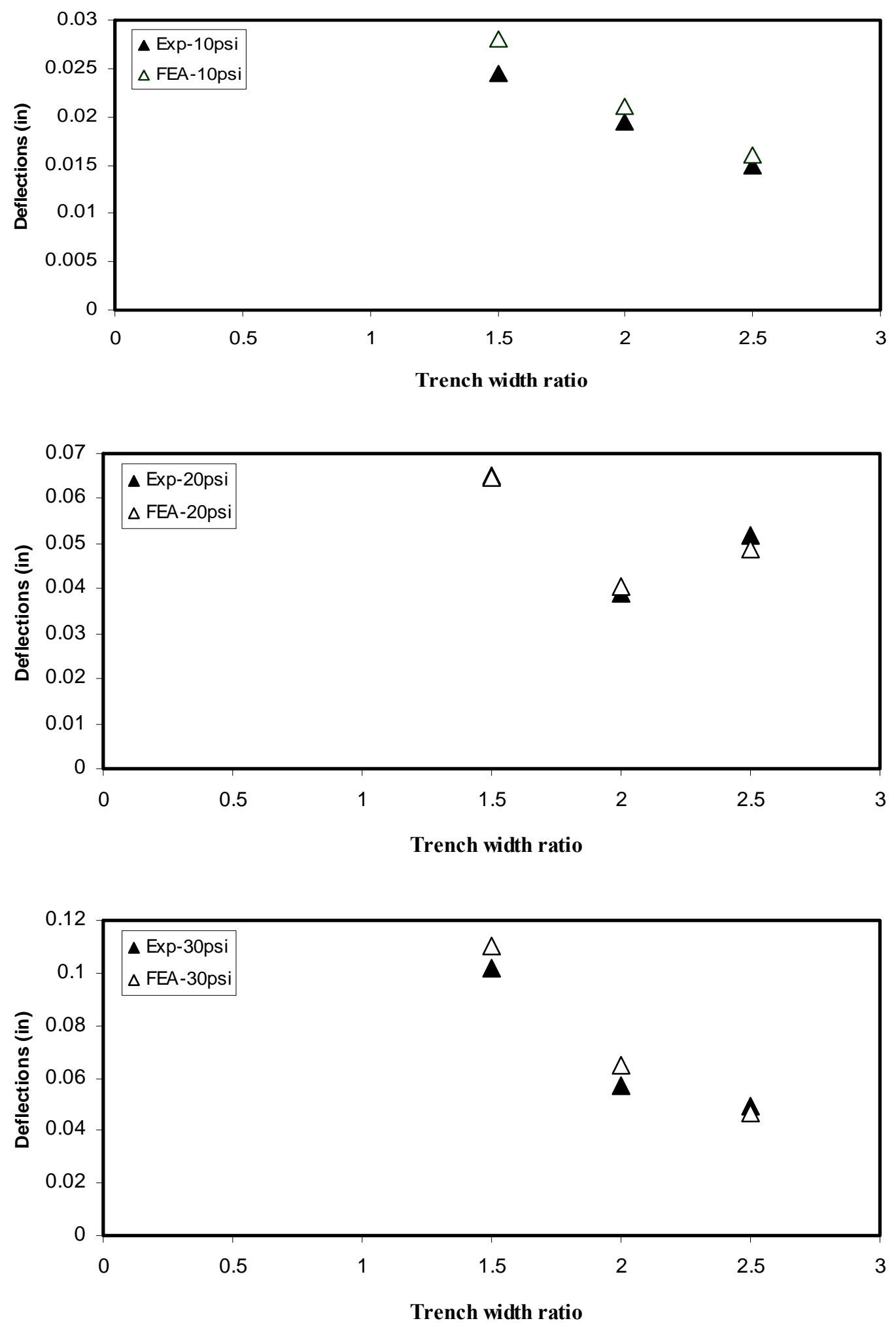

Figure 5.6: Pipe deflections under surcharge loading of the 6-inch pipe in loose insitu soil with high strength backfill 

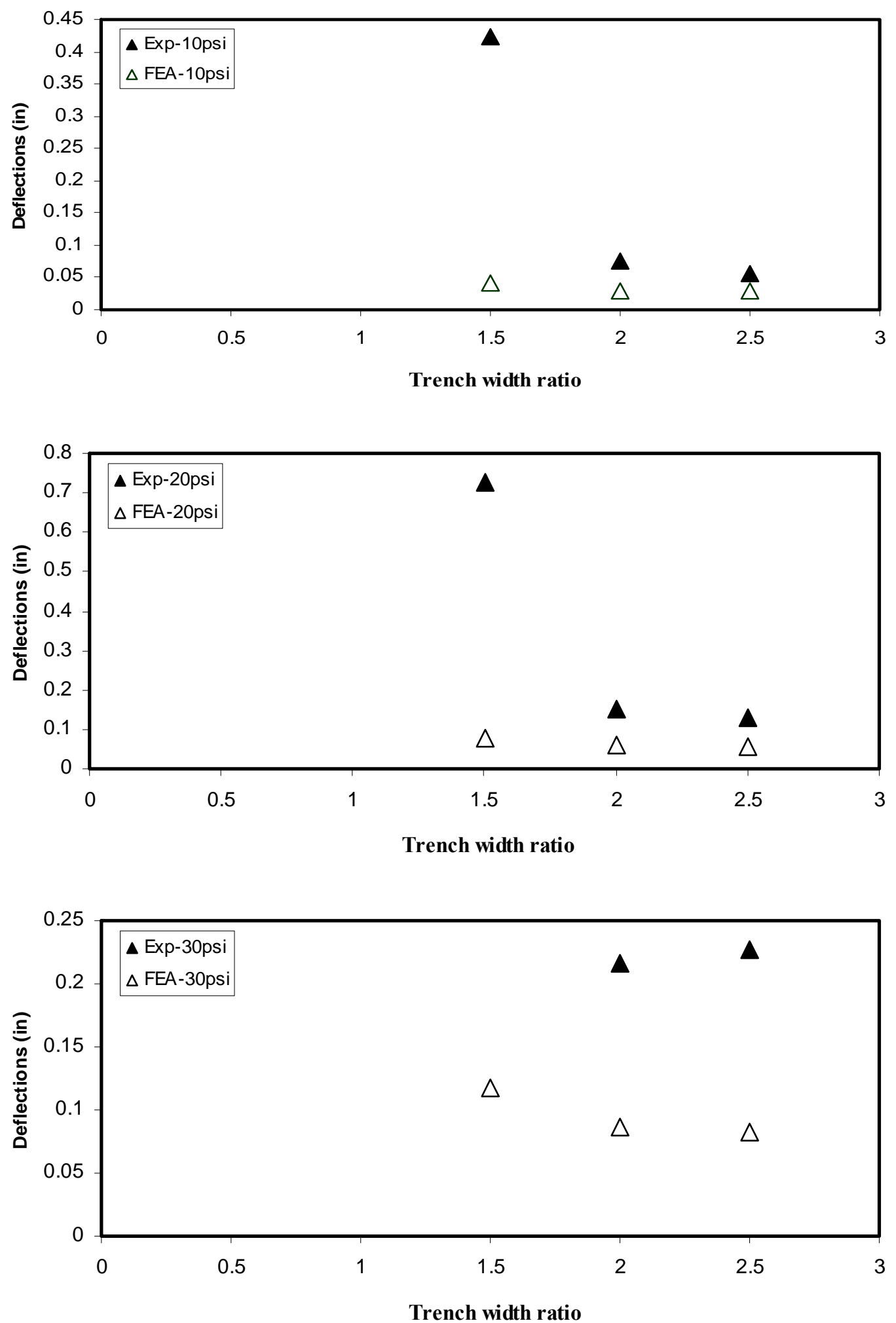

Figure 5.7: Pipe deflections under surcharge loading of the 8-inch pipe in cohesive insitu soil with low strength backfill 

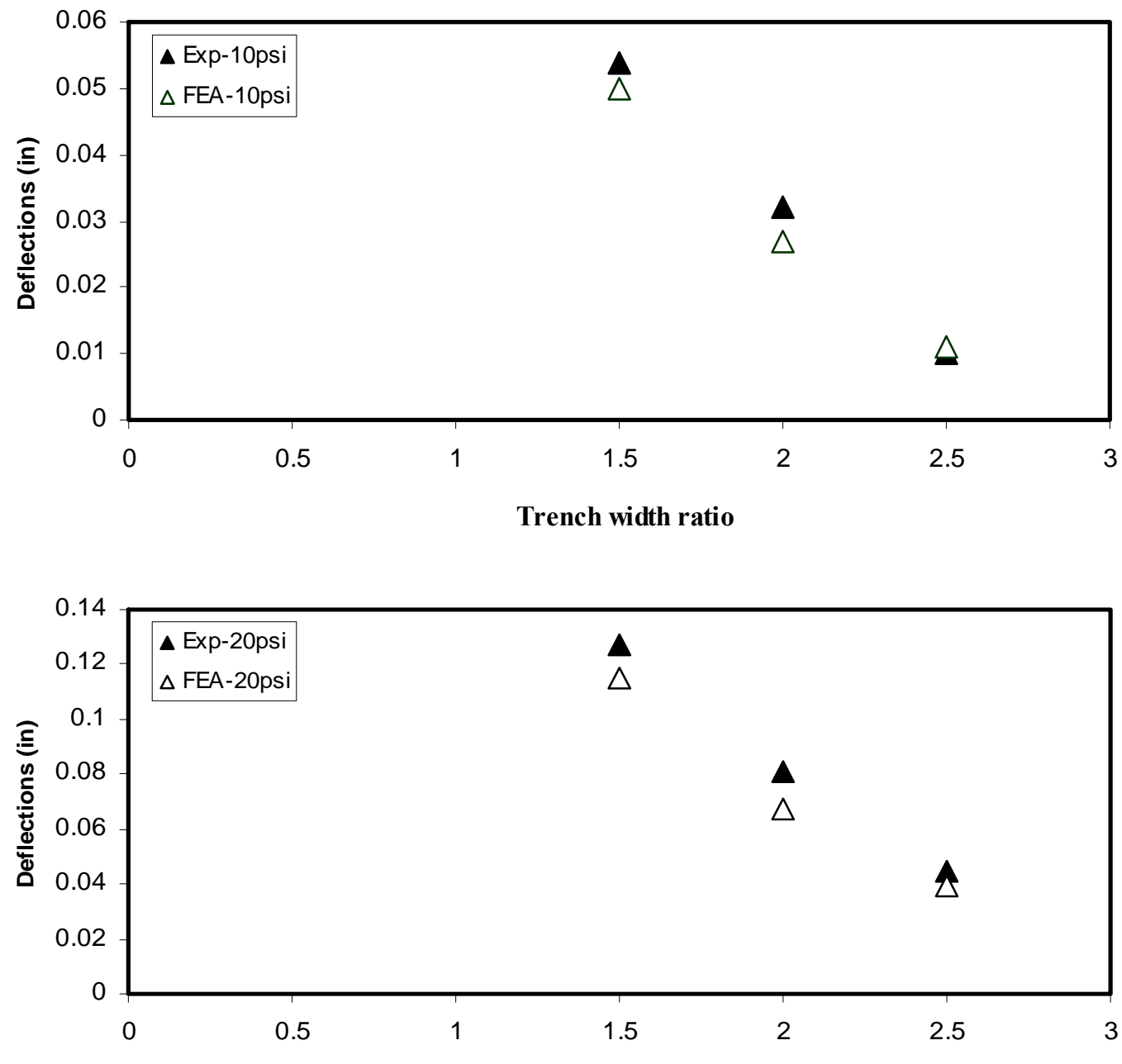

Trench width ratio

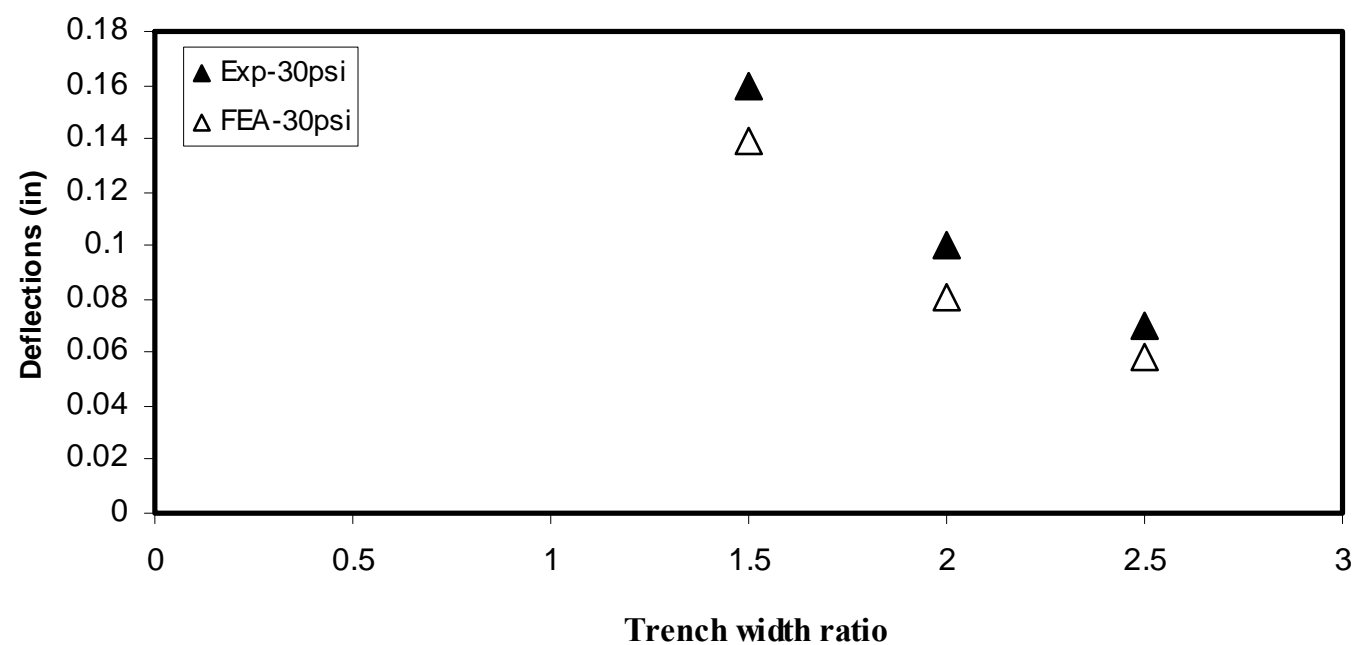

Figure 5.8: Pipe deflections under surcharge loading of the 8-inch pipe in cohesive insitu soil with high strength backfill 

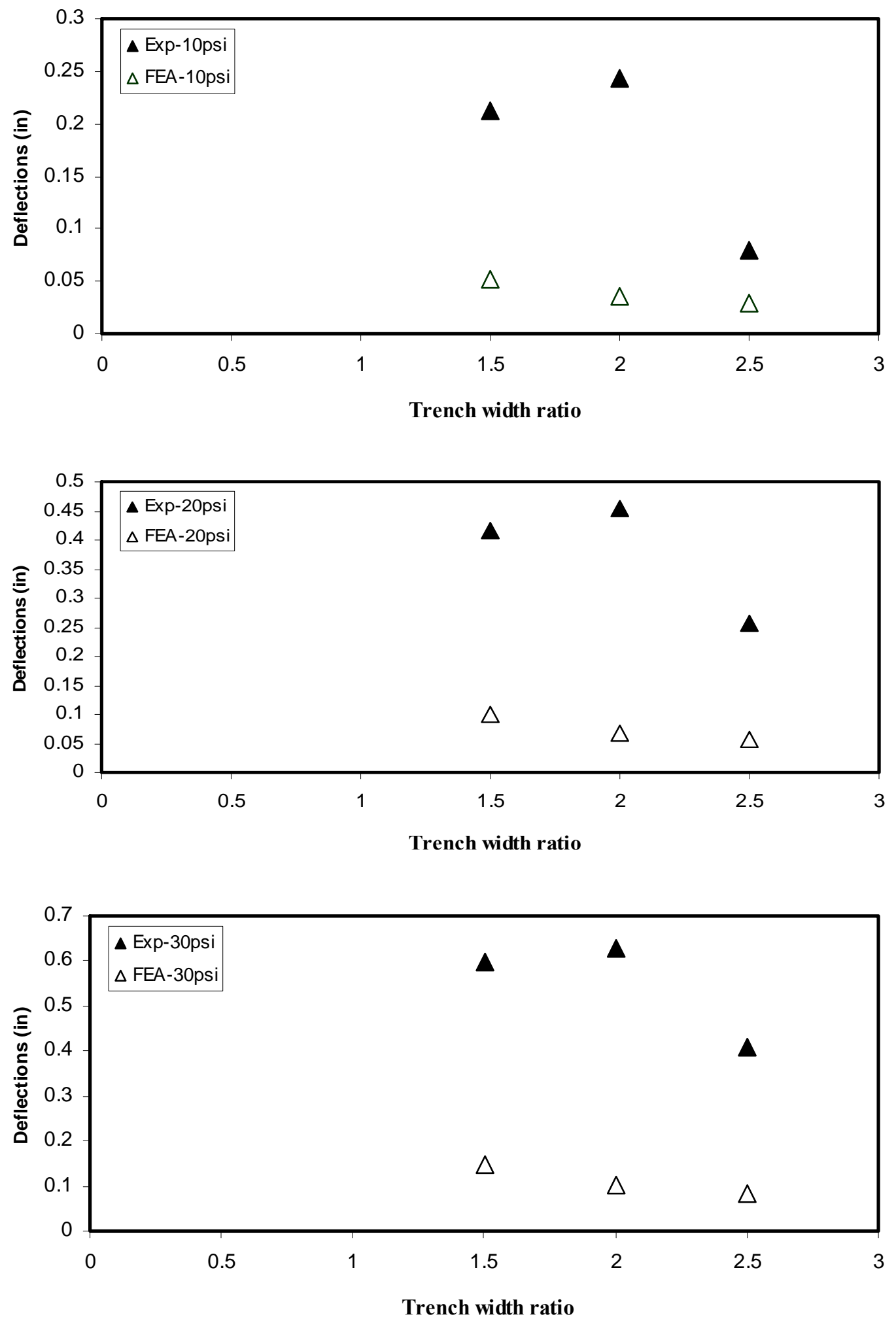

Figure 5.9: Pipe deflections under surcharge loading of the 8-inch pipe in loose insitu soil with low strength backfill 

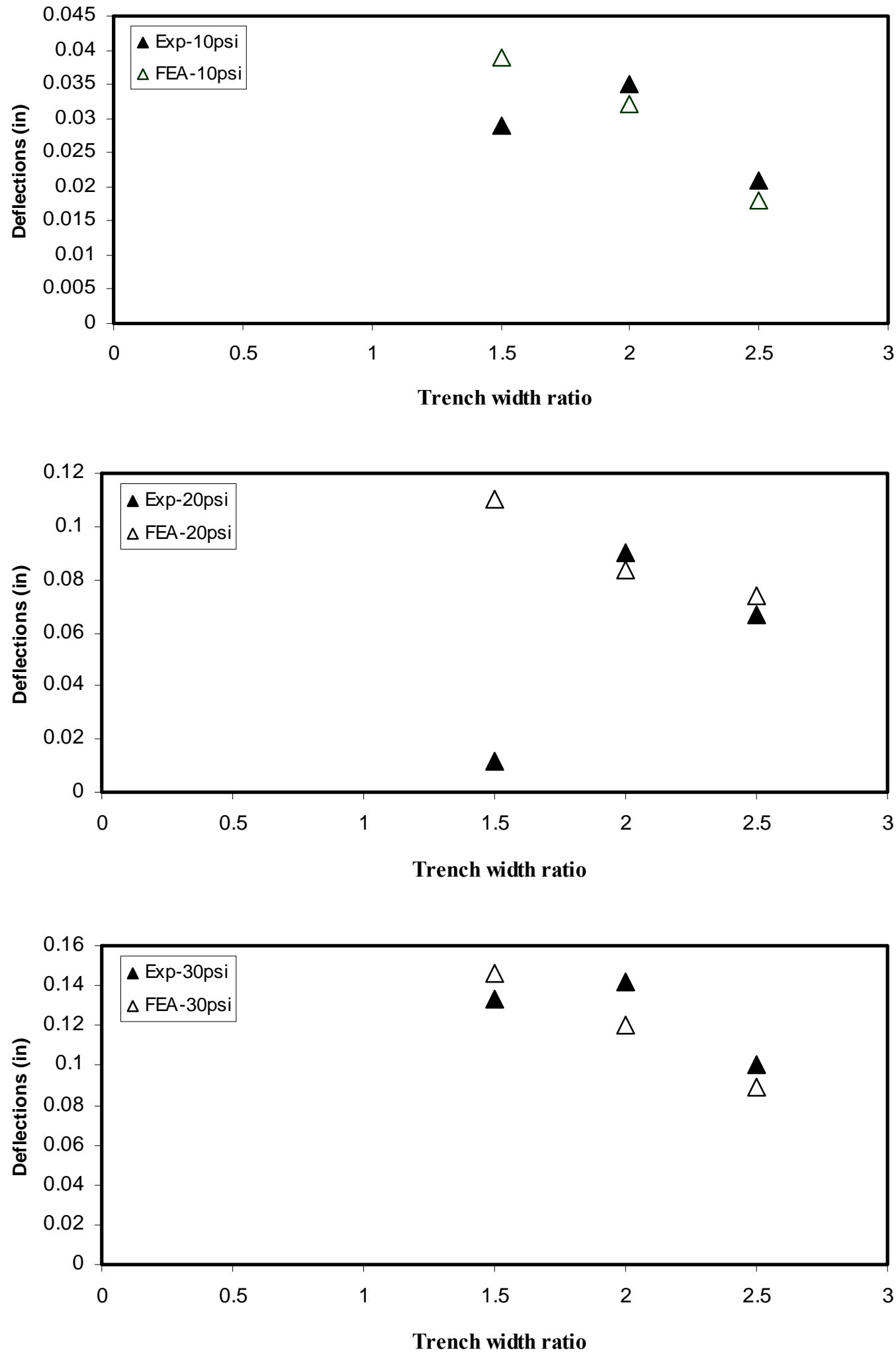

Figure 5.10: Pipe deflections under surcharge loading of the 8-inch pipe in loose insitu soil with high strength backfill 

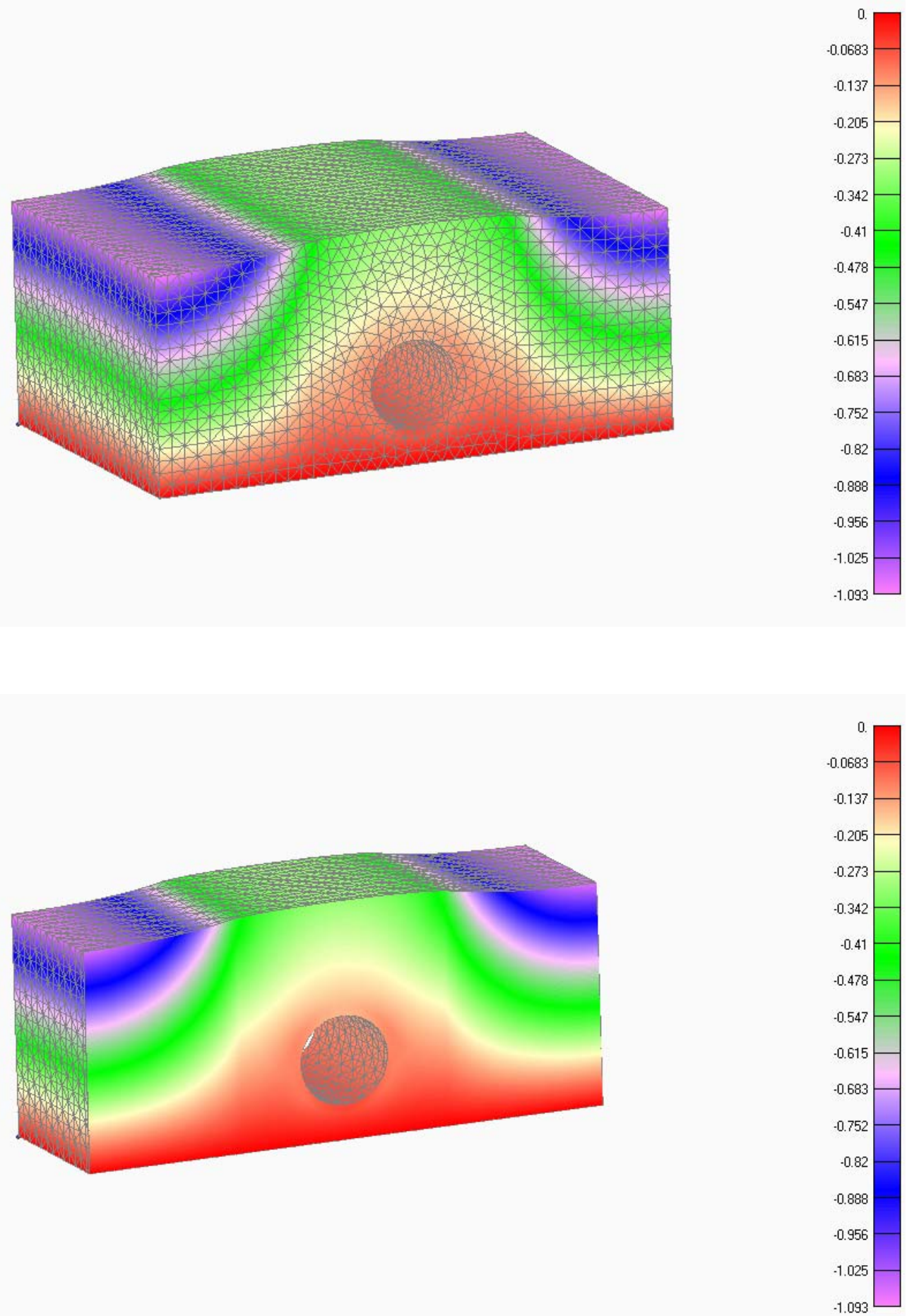

Figure 5.11: Soil-pipe deformation contours for of the 8-inch pipe with trench width ratio 2 under 20 psi surcharge loading 


\subsection{Soil stresses due to surcharge loading}

Buried flexible pipes derive their stability from surrounding soil (Moore, 1995). Therefore, the stress distribution in the surrounding soil is an important factor. Figures 5.15 to 5.18 show stress distribution around a buried pipe for surcharge loading between 10 psi (69 Pa) and $30 \mathrm{psi}(207 \mathrm{~Pa})$. These figures show the vertical stresses in the soil under the centerline of the pipe as a function of trench width ratio. As evident from these figures, the vertical stress decreases with an increase in trench width ratio. Figure 5.12 shows the location of the pressure cell at which the vertical stresses were measured. The theory of arching indicates that when a material in a trench deflects downward, the frictional forces on the interface between the insitu soil and the backfilled material will carry some of the surface load (Watkins, 1999). Under certain conditions arching can develop stresses that are greater than the static stresses caused by the total weight of the overlaying soil and the surface loads. Such a condition is reffered to as negative arching. On the other hand positive arching will generate stresses that are significantly less than the static stresses caused by the weight of the overlaying soil (Spangler and Handy, 1982). Figure 5.13 and Figure 5.14 show a schematic diagram of a buried pipe under negative arching and positive arching, respectively. In the laboratory experiments reported in this section, the flowable backfill material is much stronger and deflects less than the insitu soil. This leads to negative arching. In this case, the insitu soil is deflecting and the CLSM is taking on additional loads due to the friction force caused by the moving mass. Tables A.9 to A.11 and Tables A.12 to A.14 in Appendix A show numerical values of pipe stresses under surcharge loading conditions for 6-inch $(15.2 \mathrm{~cm})$ pipes and 8-inch $(20.3 \mathrm{~cm})$ pipes, respectively.

Arching theory is applicable when there are two soil masses that settle at different rates. When the insitu soil settles more than the backfill, the insitu soil applies an additional load on the backfill rather than relieving some of the load. CLSM with a small trench width might be carrying much more load than expected because of the frictional forces caused by different rates of settlements. This relatively high load could lead to high deflections or even pipe failure if the CLSM is not designed properly to account for arching. 
Stresses under uniform surcharge loading for the 6-inch $(15.2 \mathrm{~cm})$ pipe in cohesive insitu soil and low strength backfill are tabulated in Table A.9. Figure 5.15 presents the variation of pressure (vertical stress) with the trench width ratio $\left(\mathrm{N}_{\mathrm{r}}\right)$. The experimental data compares well with that of the finite element values at lower surcharge loading conditions. The comparison between numerical and experimental values is good for the 6-inch (15.2 $\mathrm{cm})$ pipe in cohesive insitu soil with high strength backfill material as shown in Figure 5.16. Similarly, for the 6 -inch $(15.2 \mathrm{~cm})$ pipe in loose insitu soil and low strength backfill the comparison is good at lower loading conditions compared to that of the higher loading conditions as shown in Figure 5.17.

For the 8-inch $(20.3 \mathrm{~cm})$ pipe under cohesive insitu soil and low strength backfill the comparison between the experimental values and the finite element values is good at higher trench width ratios as shown in Figure 5.18. Again for the 8-inch $(20.3 \mathrm{~cm})$ pipe in cohesive insitu soil with high strength backfill material, the stresses compared well at all trench width ratios and loading conditions as shown in Figure 5.19. The experimental vertical stresses around the pipe of the 8 -inch $(20.3 \mathrm{~cm})$ pipe under loose insitu soil and low strength backfill do not compare well with that of the finite element stress values at certain trench width ratios. These results are shown in Figure 5.20.

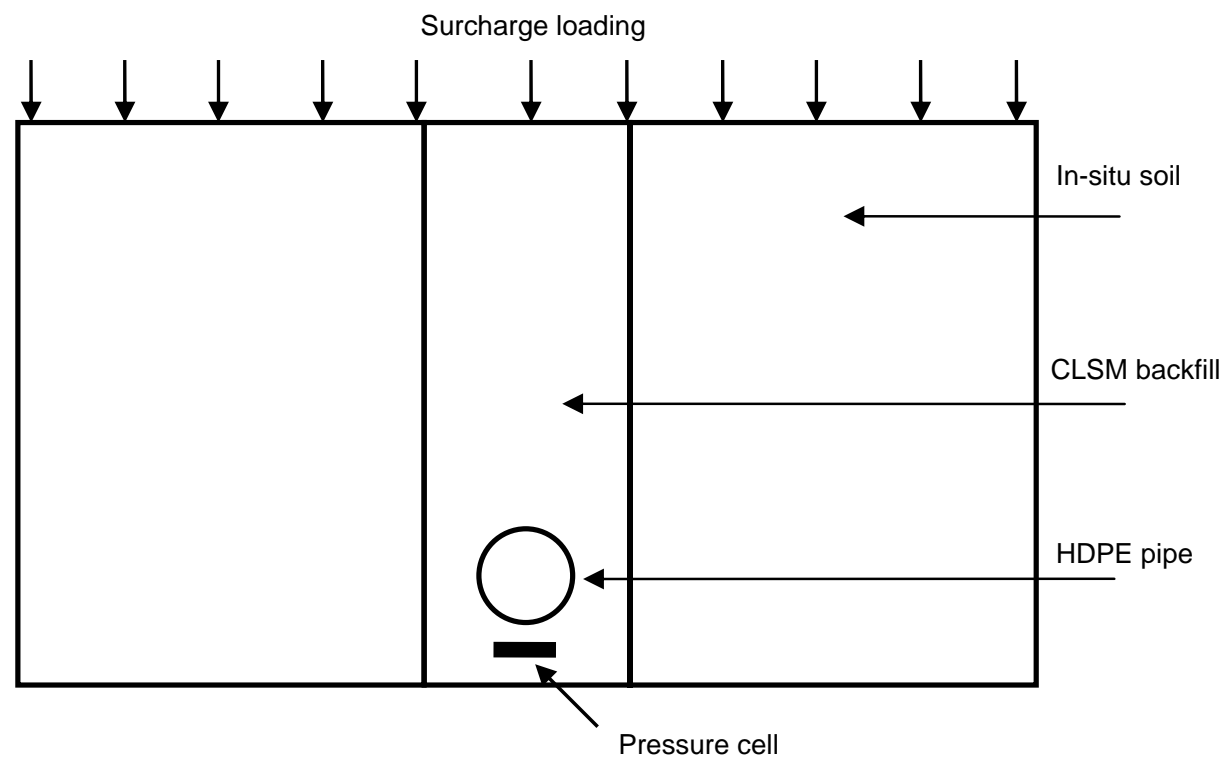

Figure 5.12: Location of pressure cell under the centerline of the pipe 


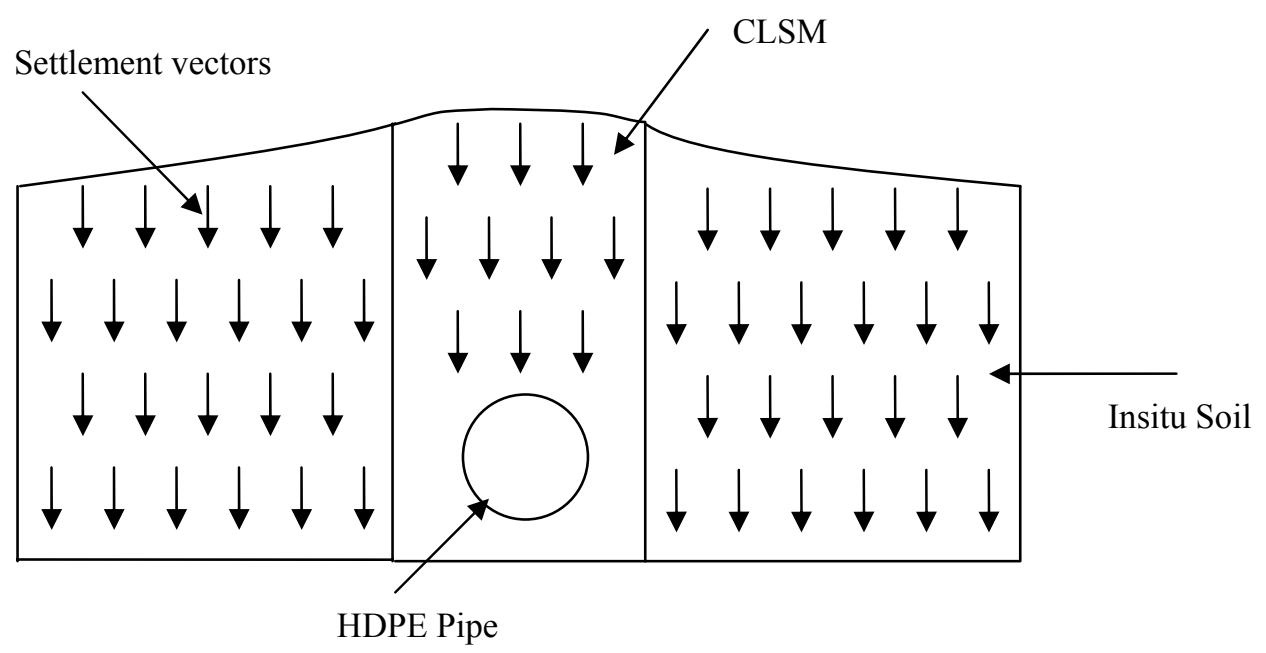

Figure 5.13: Schematic diagram of Negative Arching

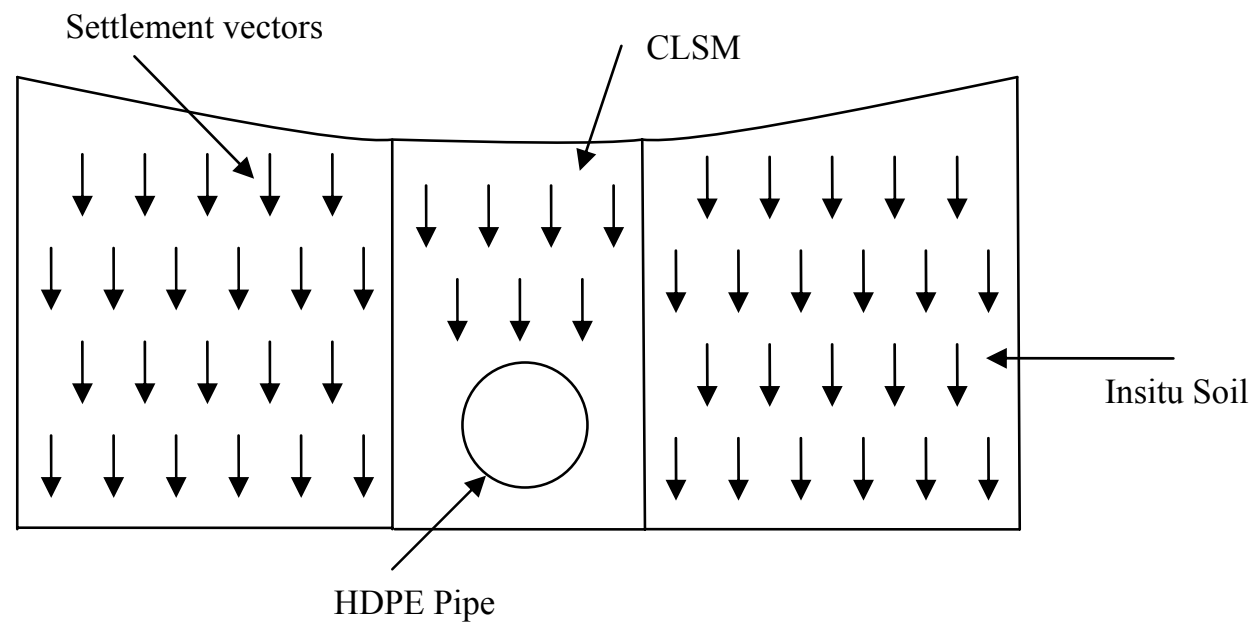

Figure 5.14: Schematic diagram of Positive Arching 

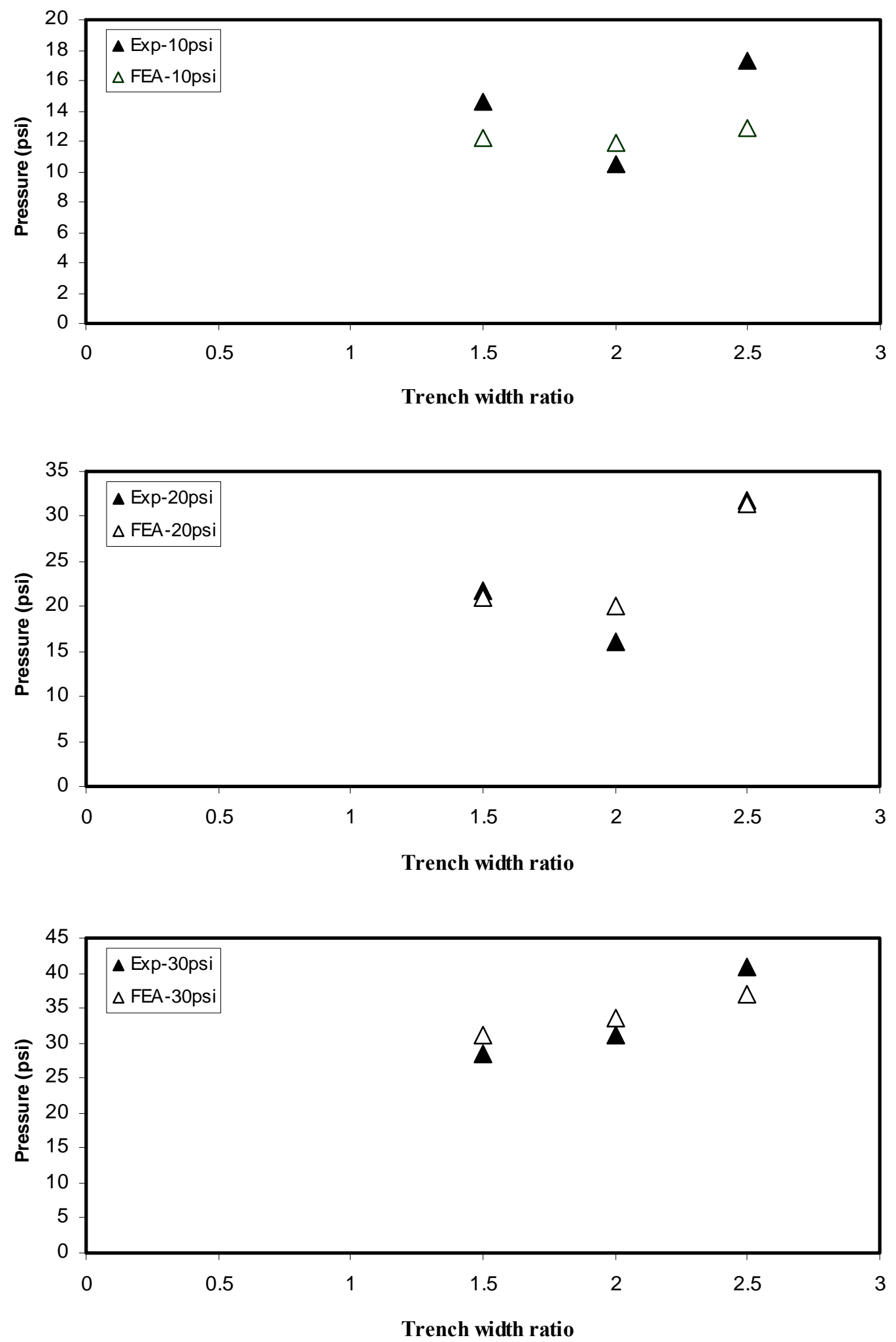

Figure 5.15: Stresses under surcharge loading of the 6-inch pipe in cohesive insitu soil with low strength backfill 

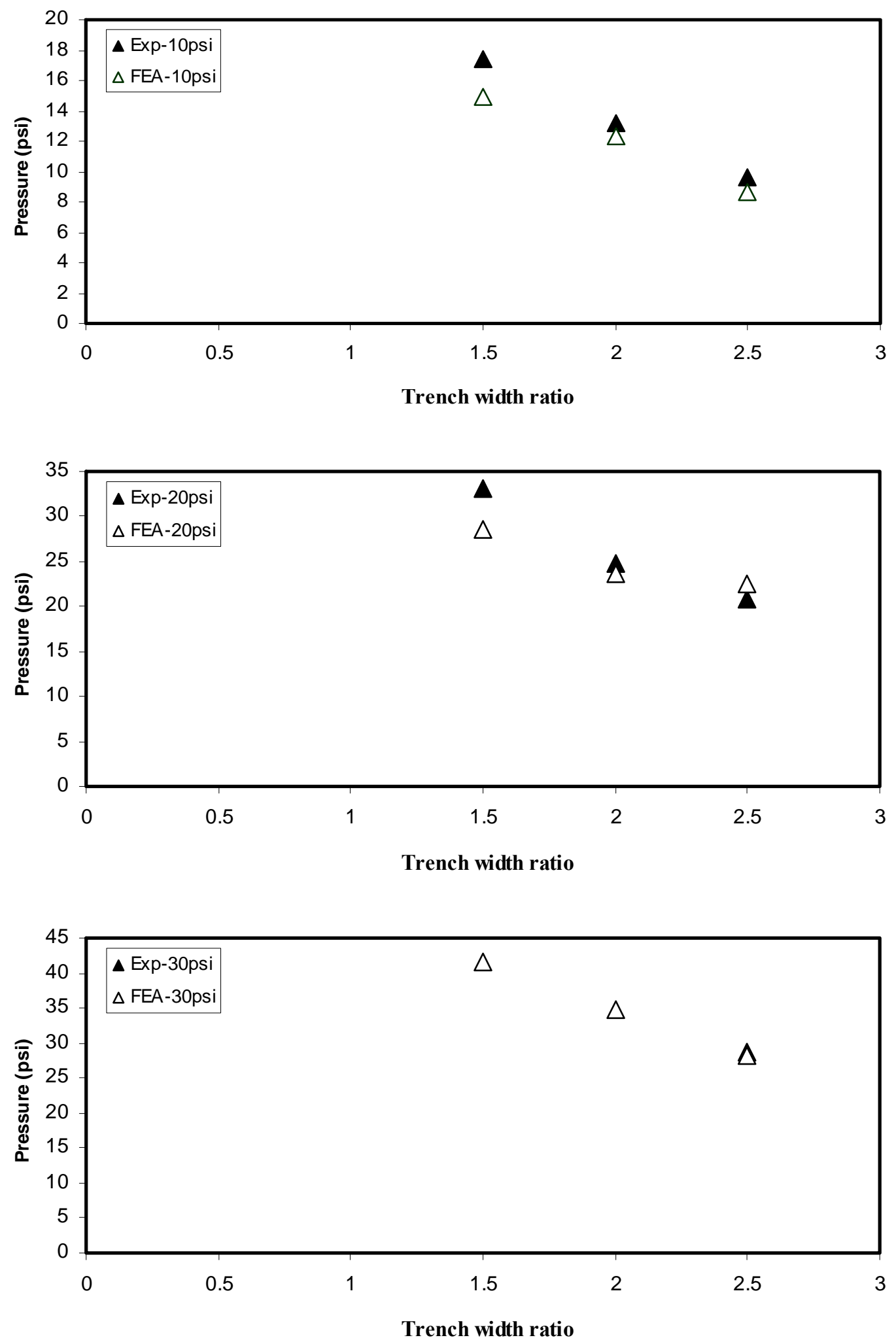

Figure 5.16: Stresses under surcharge loading of the 6-inch pipe in cohesive insitu soil with high strength backfill 

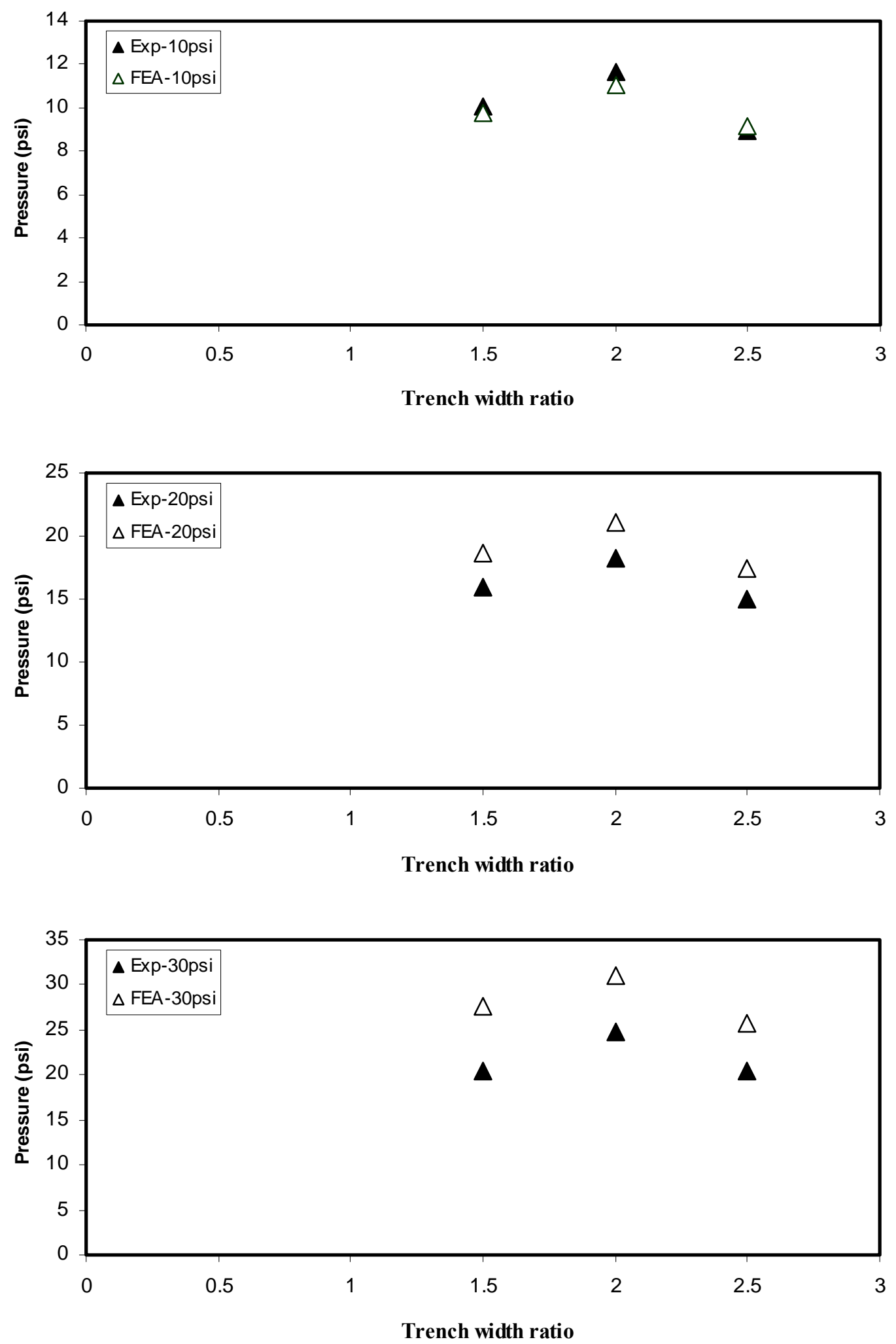

Figure 5.17: Stresses under surcharge loading of the 6-inch pipe in loose insitu soil with low strength backfill 

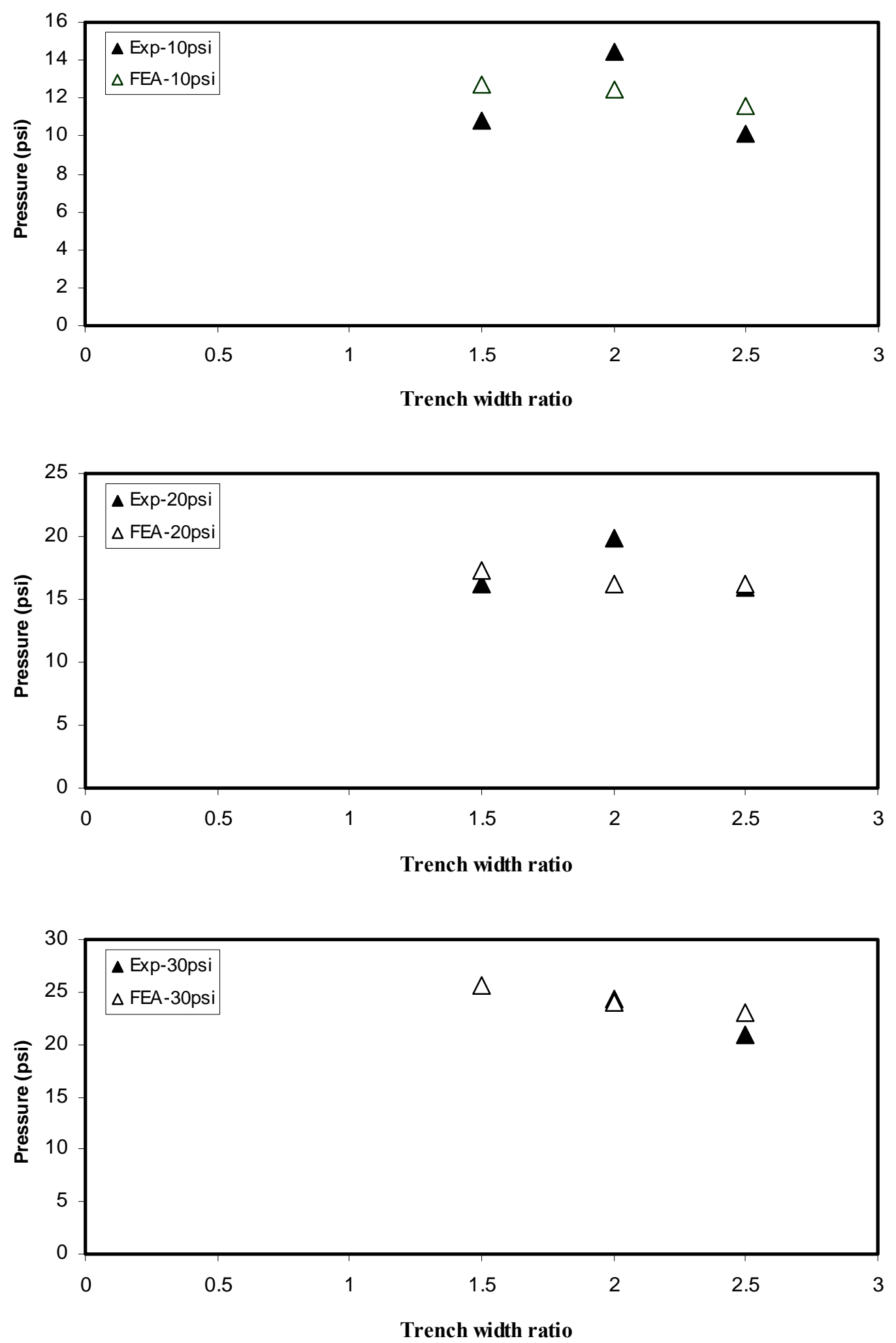

Figure 5.18: Stresses under surcharge loading of the 8-inch pipe in cohesive insitu soil with low strength backfill 

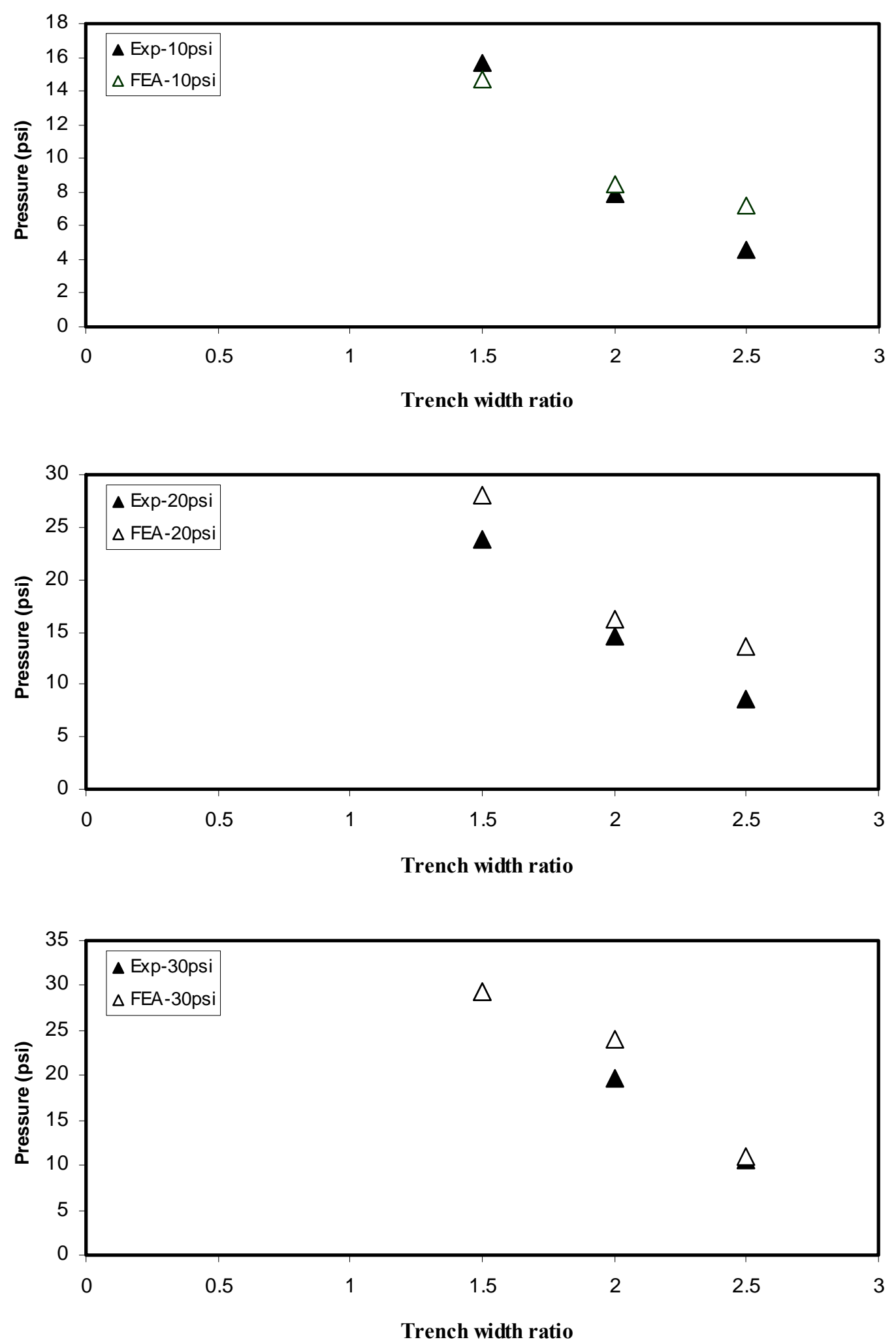

Figure 5.19: Stresses under surcharge loading of the 8-inch pipe in cohesive insitu soil with high strength backfill 

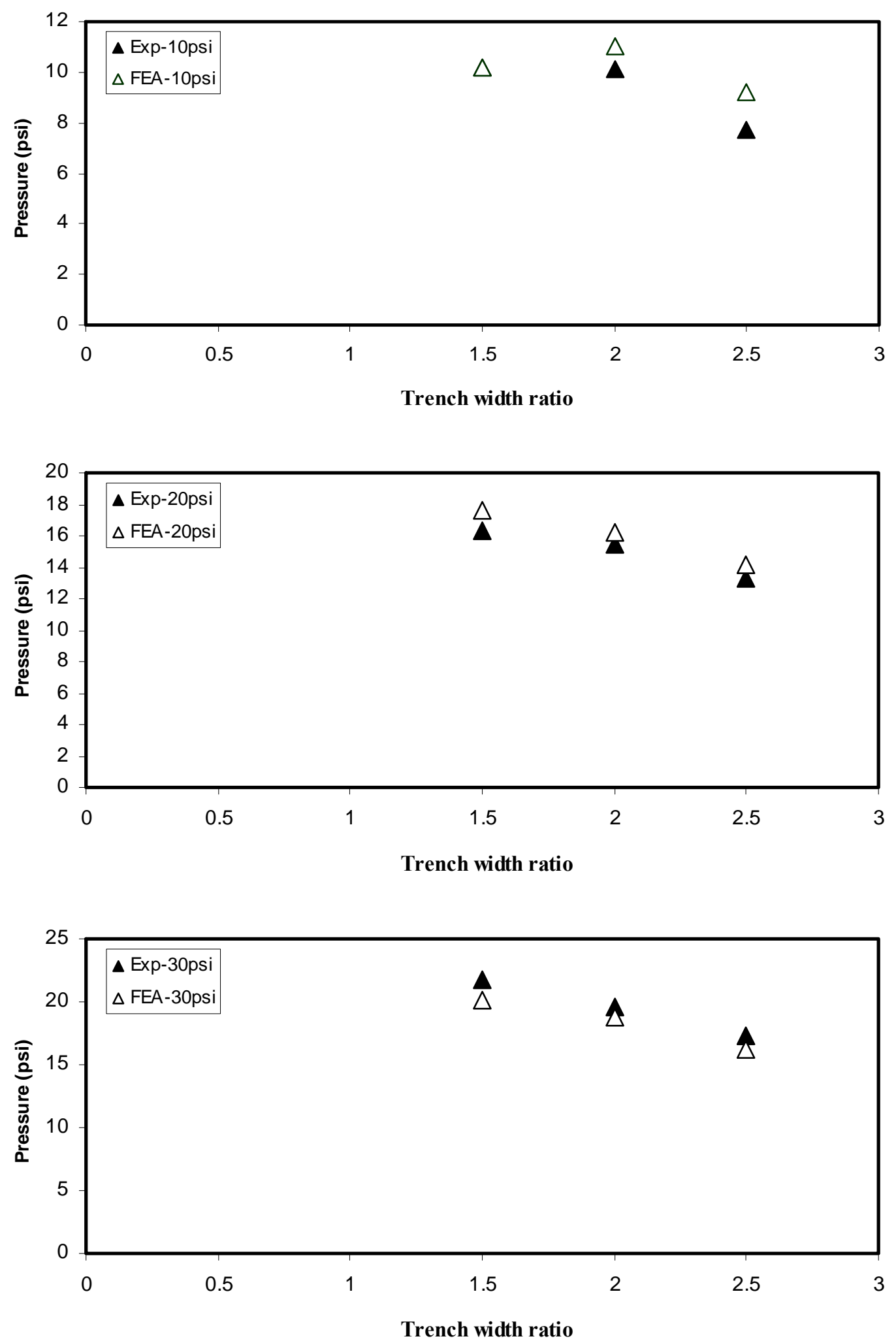

Figure 5.20: Stresses under surcharge loading of the 8-inch pipe in loose insitu soil with low strength backfill 

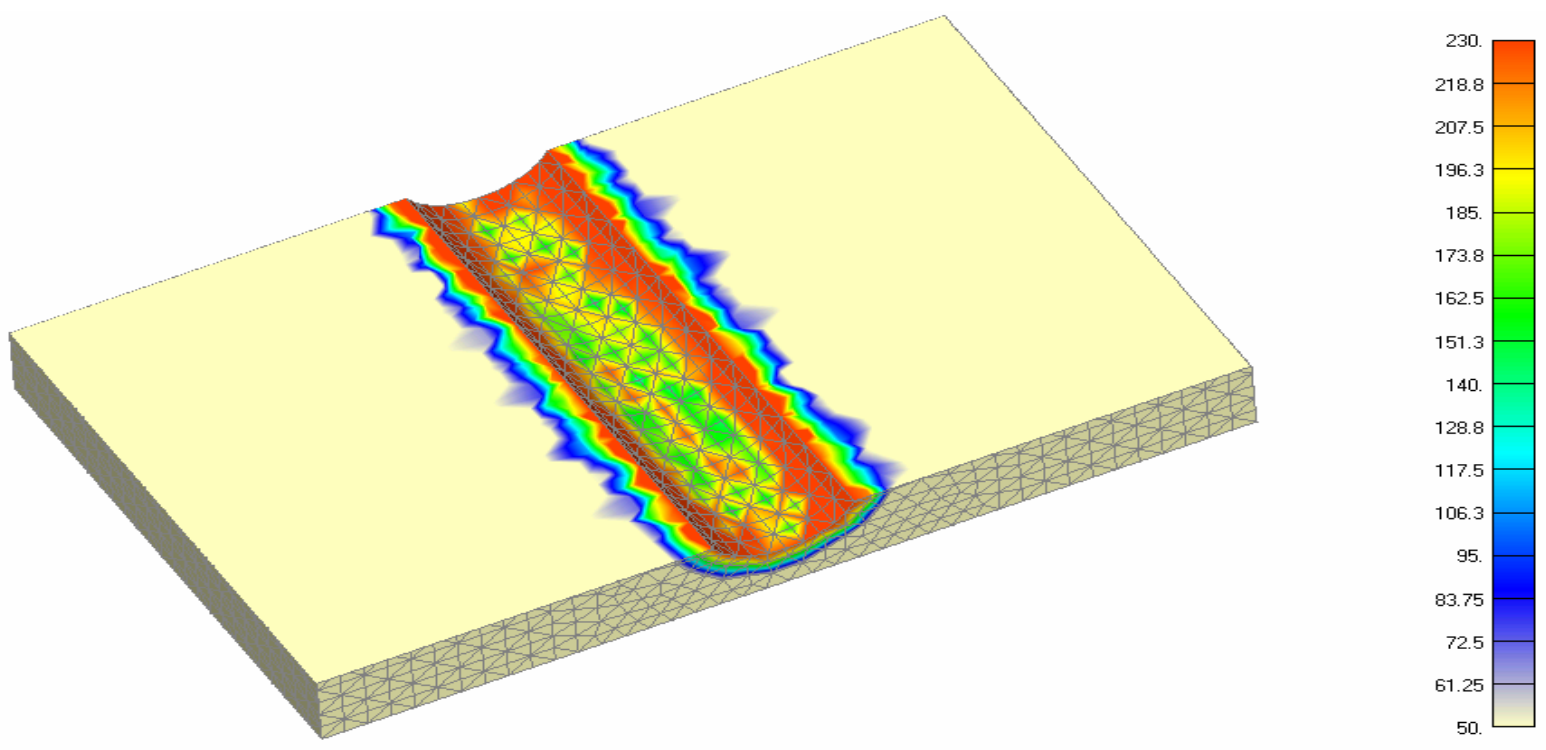

(a) 6-inch pipe
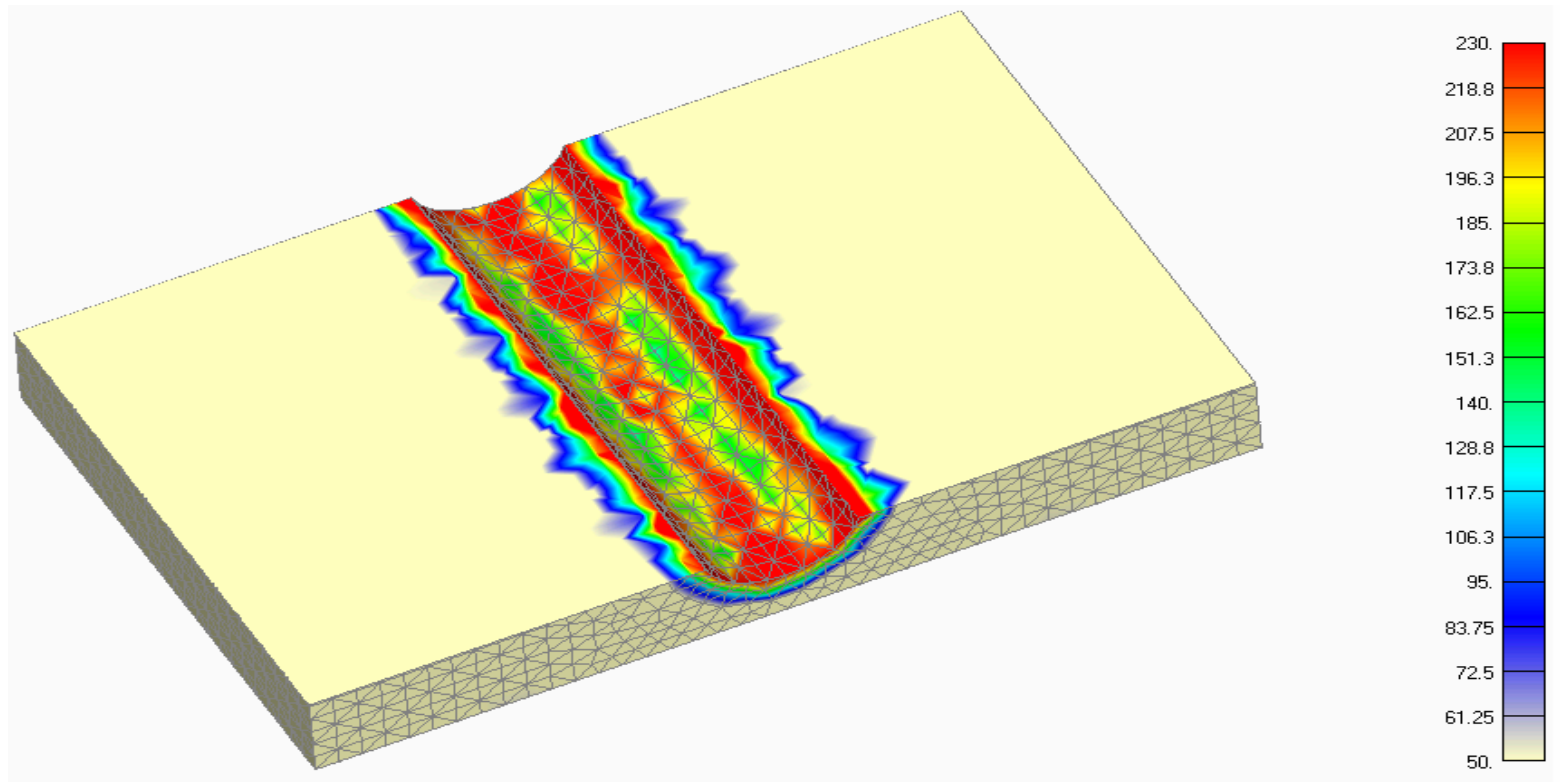

(b) 8-inch pipe

Figure 5.21: Von mises stress for the 6-inch and the 8-inch pipe under a surcharge loading of 30 psi with low CLSM backfill 


\subsection{Pipe deflections due to plate loading}

Figures 5.22 to 5.24 show the deflection of the 6 -inch $(15.2 \mathrm{~cm})$ pipe deflection for plate loading of 1,000 lb $(4,448 \mathrm{~N}), 2,000 \mathrm{lb}(8,896 \mathrm{~N})$, and 3,000 lb $(13,344 \mathrm{~N})$. In these figures, deflections are presented as a function of trench width ratio $\left(\mathrm{N}_{\mathrm{r}}\right)$. These figures show that the pipe deflections decrease with an increase in trench width ratio $\left(\mathrm{N}_{\mathrm{r}}\right)$. Experimental data is not available for pipe deflections under plate loading conditions.

The numerical values of the maximum pipe deflections for the 6 -inch $(15.2 \mathrm{~cm})$ pipe under cohesive in-situ soils with low strength backfill materials are tabulated in Table A.15. The numerical values of the maximum pipe deflections for the 6-inch $(15.2 \mathrm{~cm})$ pipe under cohesive in-situ soils with high strength backfill materials are tabulated in Table A.16. The numerical values of the maximum pipe deflections for the 6 -inch $(15.2 \mathrm{~cm})$ pipe under loose in-situ soils with low strength backfill materials are tabulated in Table A.17. The results show that the pipe deflections decrease with increasing trench width ratios. However, the deflection values are within the safe limits even for lower trench width ratios.

Figures 5.25 to 5.27 show the deflection of the 8-inch $(20.3 \mathrm{~cm})$ pipe subjected to plate loading of 1,000 lb $(4,448 \mathrm{~N}), 2,000 \mathrm{lb}(8,896 \mathrm{~N})$, and 3,000 lb $(13,344 \mathrm{~N}) .$. In these figures, deflections are presented as a function of trench width ratio $\left(\mathrm{N}_{\mathrm{r}}\right)$. These figures show that the pipe deflections decrease with an increase in trench width ratio $\left(\mathrm{N}_{\mathrm{r}}\right)$.

The numerical values of the maximum pipe deflections for the 8 -inch $(20.3 \mathrm{~cm})$ pipe under cohesive in-situ soils with low strength backfill materials are tabulated in Table A.18. The numerical values of the maximum pipe deflections for the 8 -inch $(20.3 \mathrm{~cm})$ pipe under cohesive in-situ soils with high strength backfill materials are tabulated in Table A.19. The numerical values of the maximum pipe deflections for the 8 -inch $(20.3 \mathrm{~cm})$ pipe under loose in-situ soils with low strength backfill materials are tabulated in Table A.20. The results show that the pipe deflections decrease with increasing trench width ratios. However, the deflection values are within the safe limits even for lower trench width ratios. Figure 5.28 shows the contours of soil-pipe deformation for the 8 -inch $(20.3 \mathrm{~cm})$ pipe with a trench width ratio of 2 under a 2,000 $\mathrm{lb}(8,896 \mathrm{~N})$ plate load. 

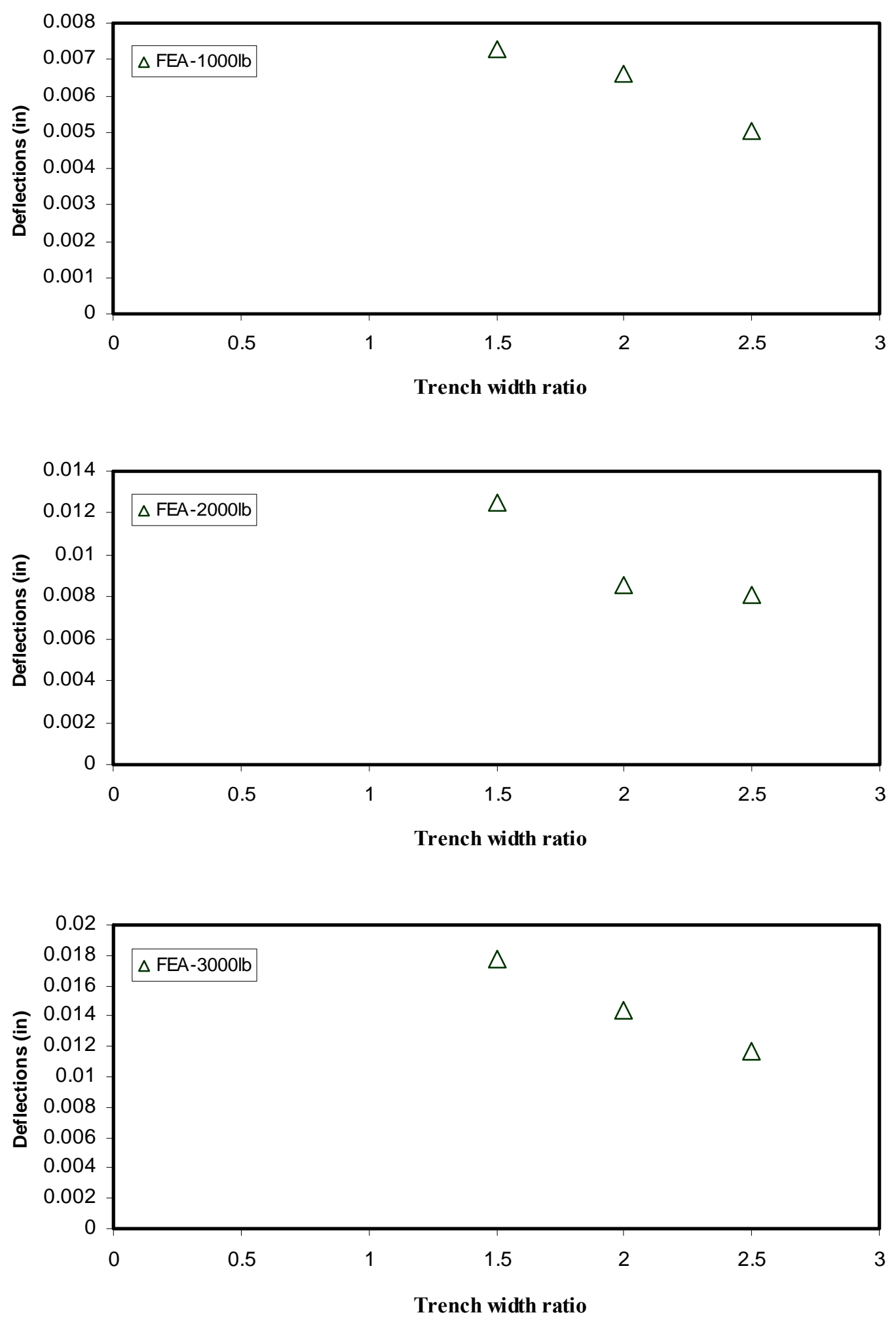

Figure 5.22: Pipe deflections under plate loading of the 6-inch pipe in cohesive insitu soil with low strength backfill 

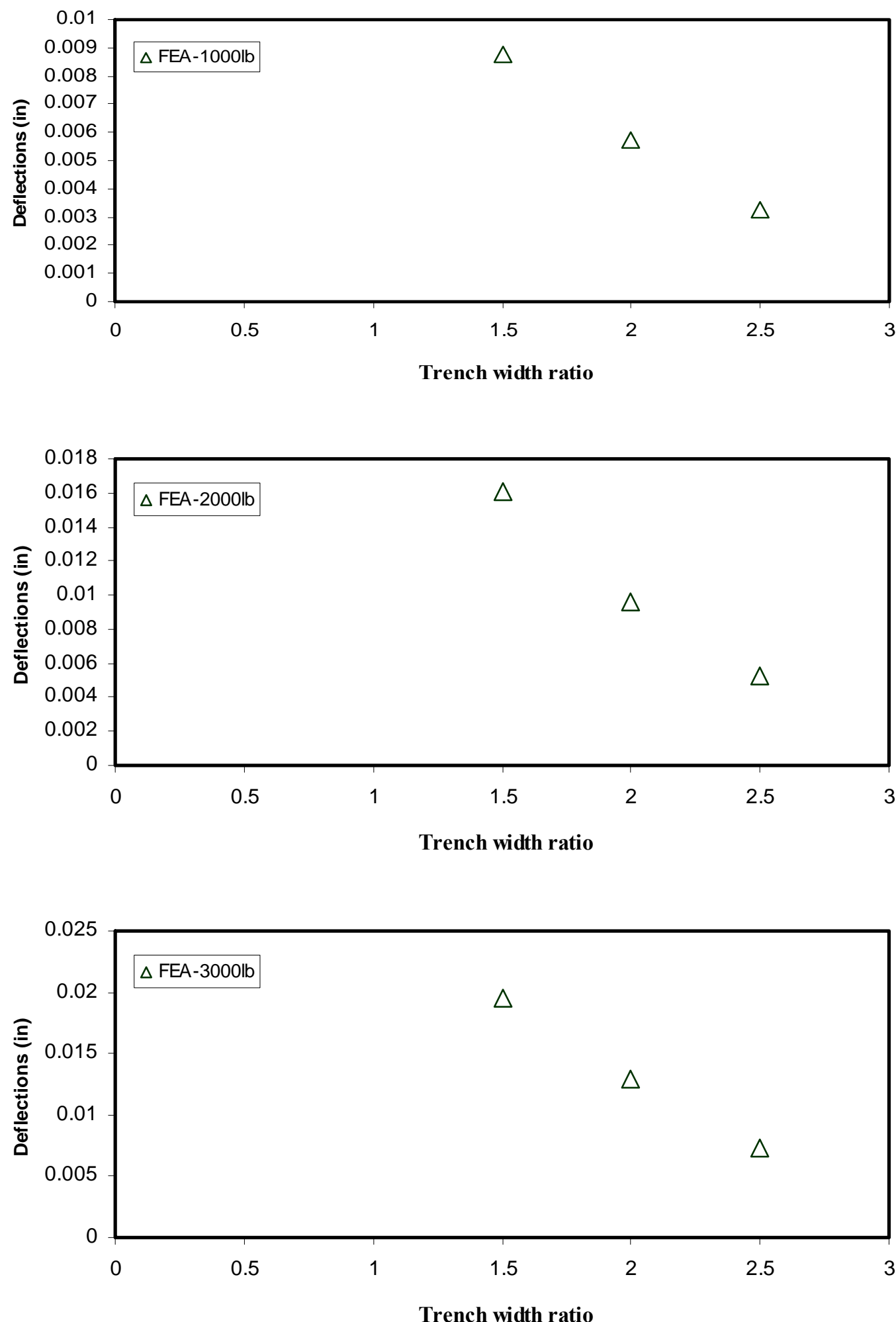

Figure 5.23: Pipe deflections under plate loading of the 6-inch pipe in cohesive insitu soil with high strength backfill 

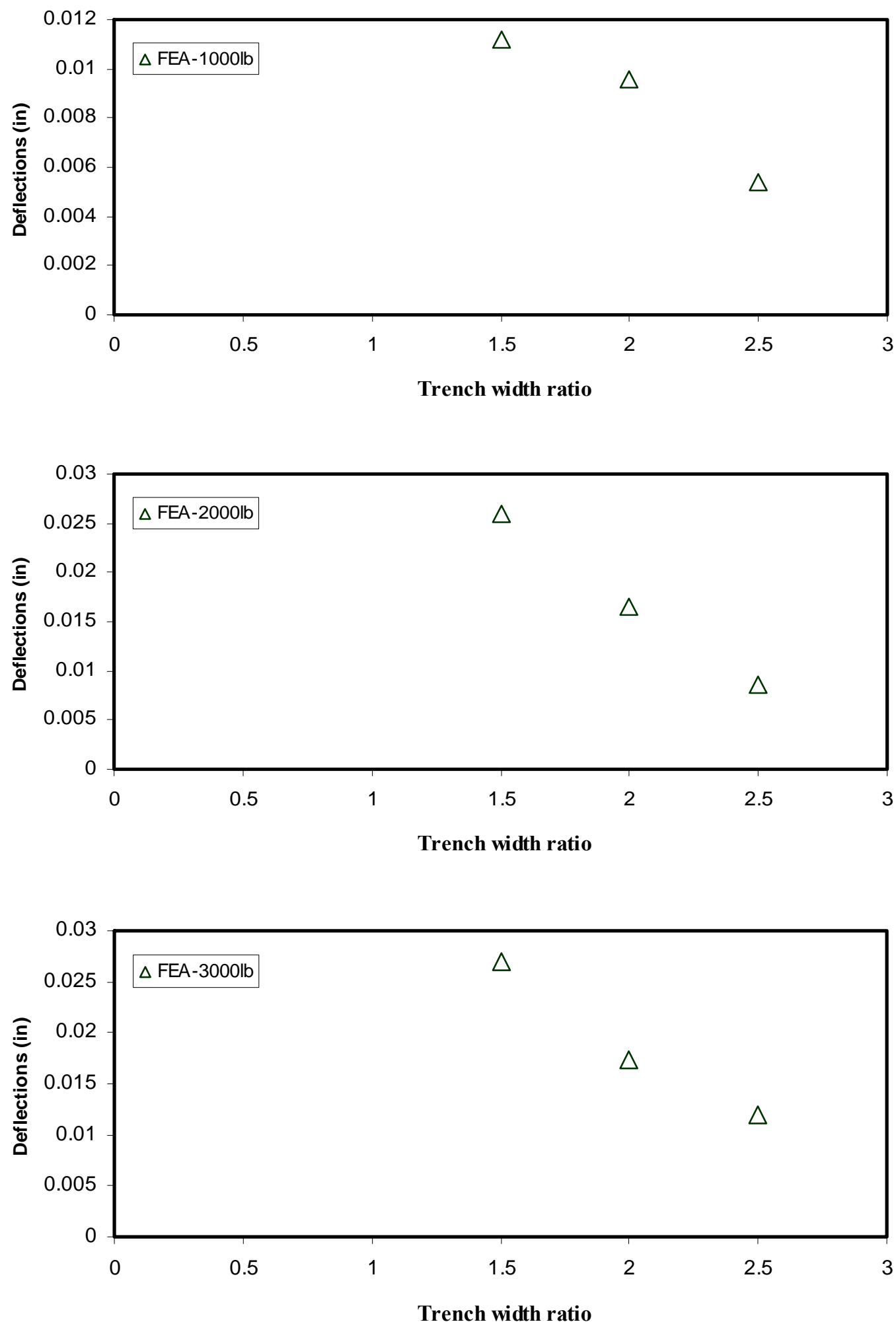

Figure 5.24: Pipe deflections under plate loading of the 6-inch pipe in loose insitu soil with low strength backfill 

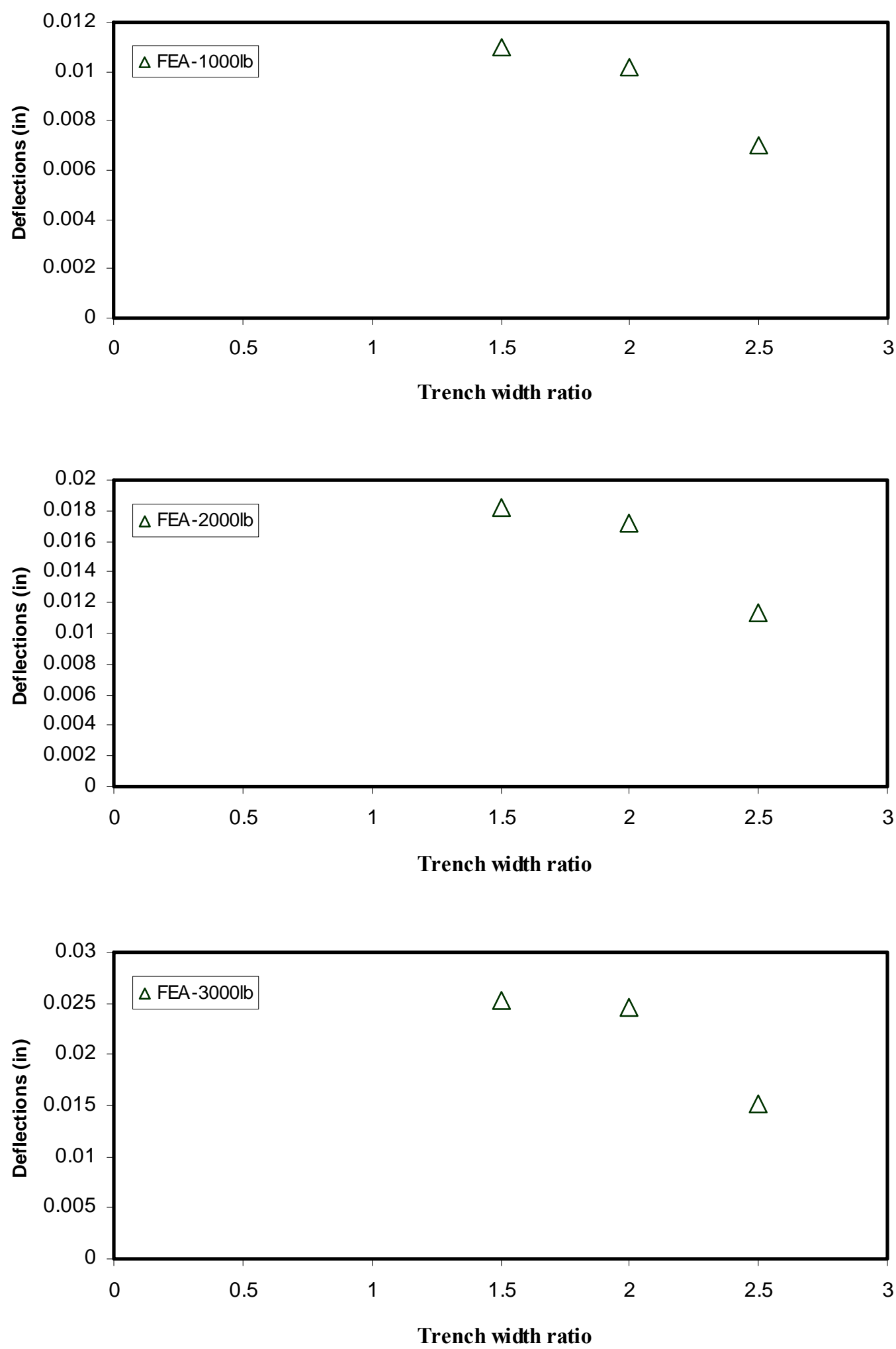

Figure 5.25: Pipe deflections under plate loading of the 8-inch pipe in cohesive insitu soil with low strength backfill 

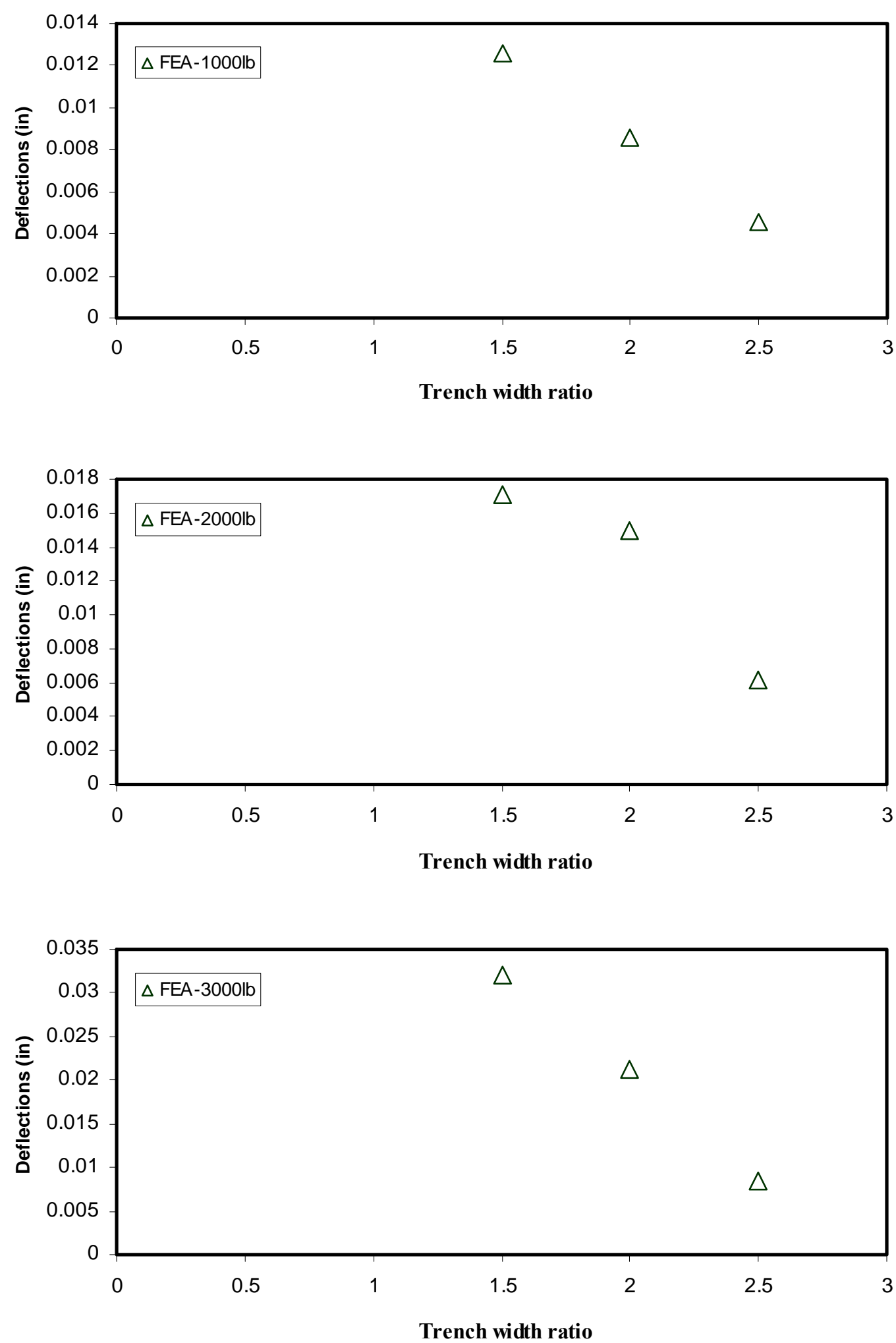

Figure 5.26: Pipe deflections under plate loading of the 8-inch pipe in cohesive insitu soil with high strength backfill 

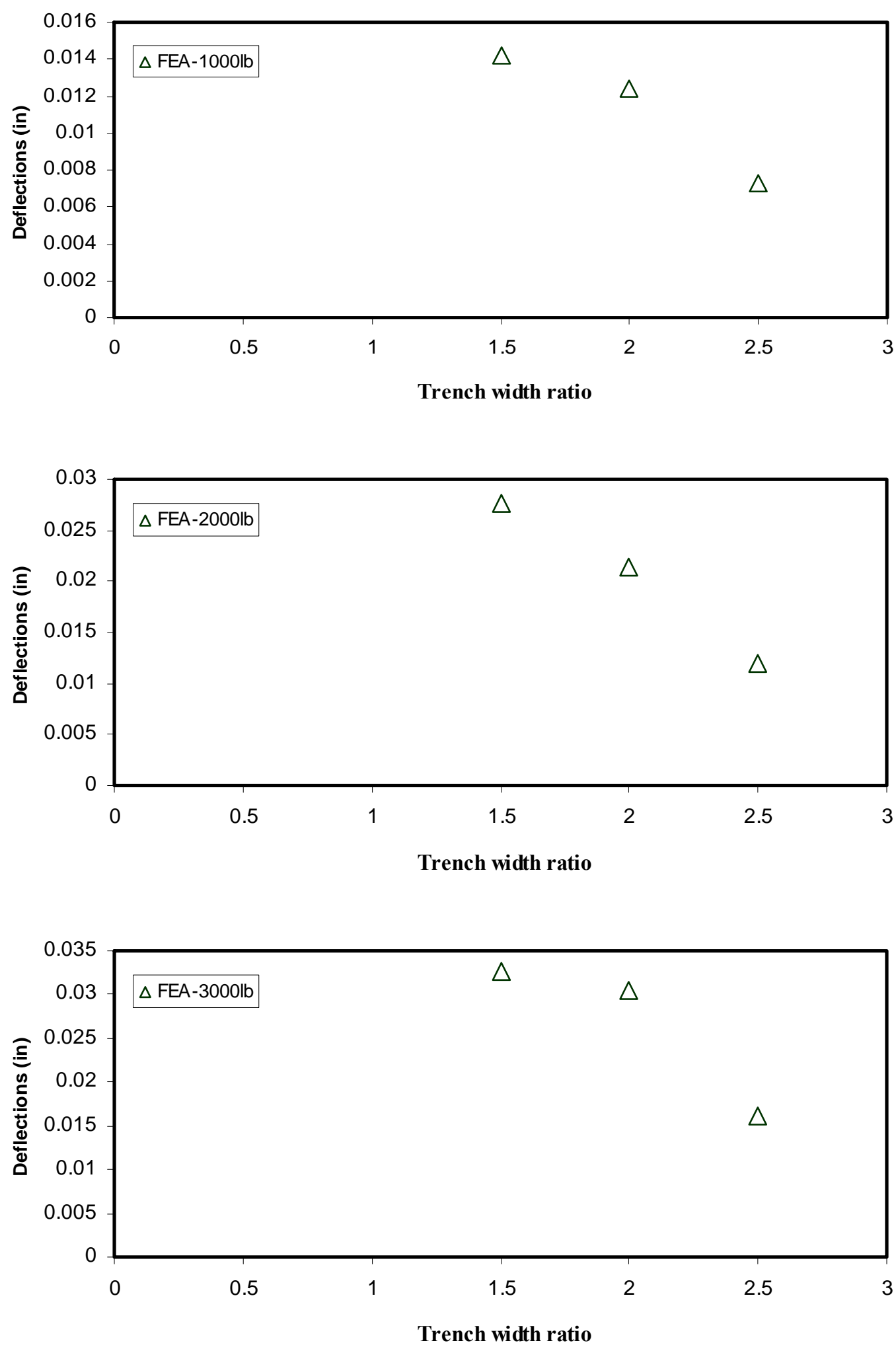

Figure 5.27: Pipe deflections under plate loading of the 8-inch pipe in loose insitu soil with low strength backfill 


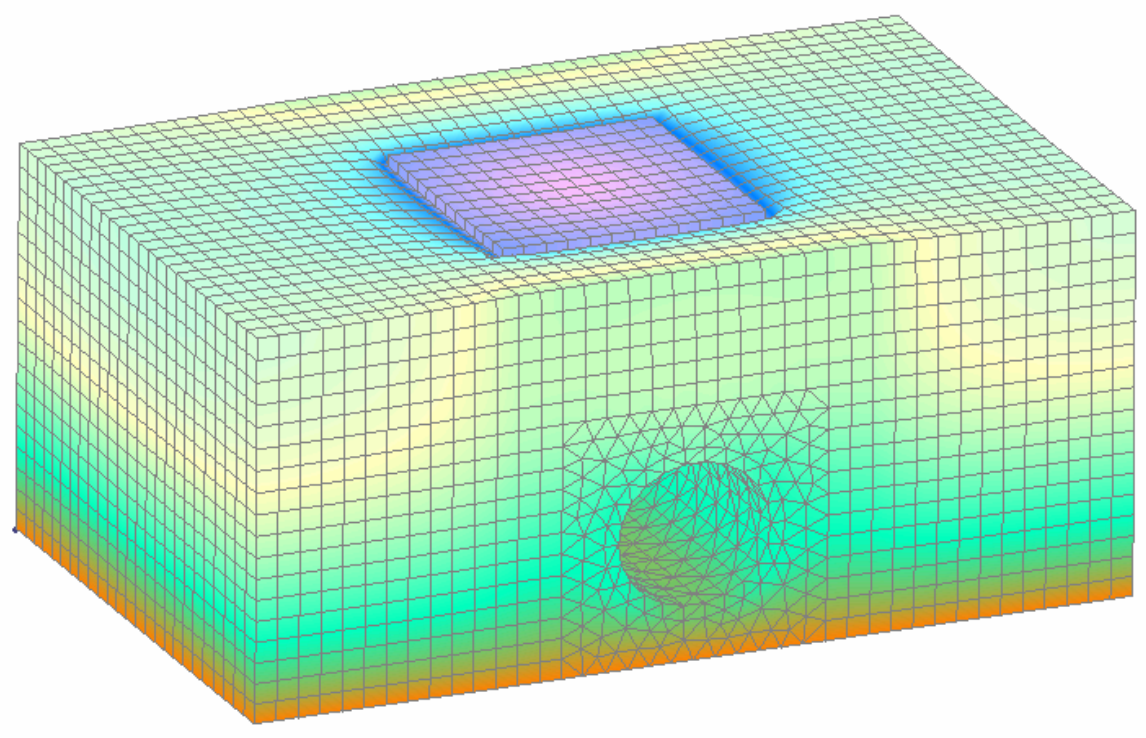

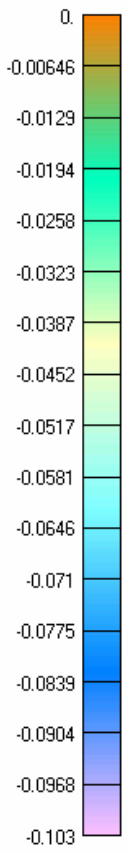
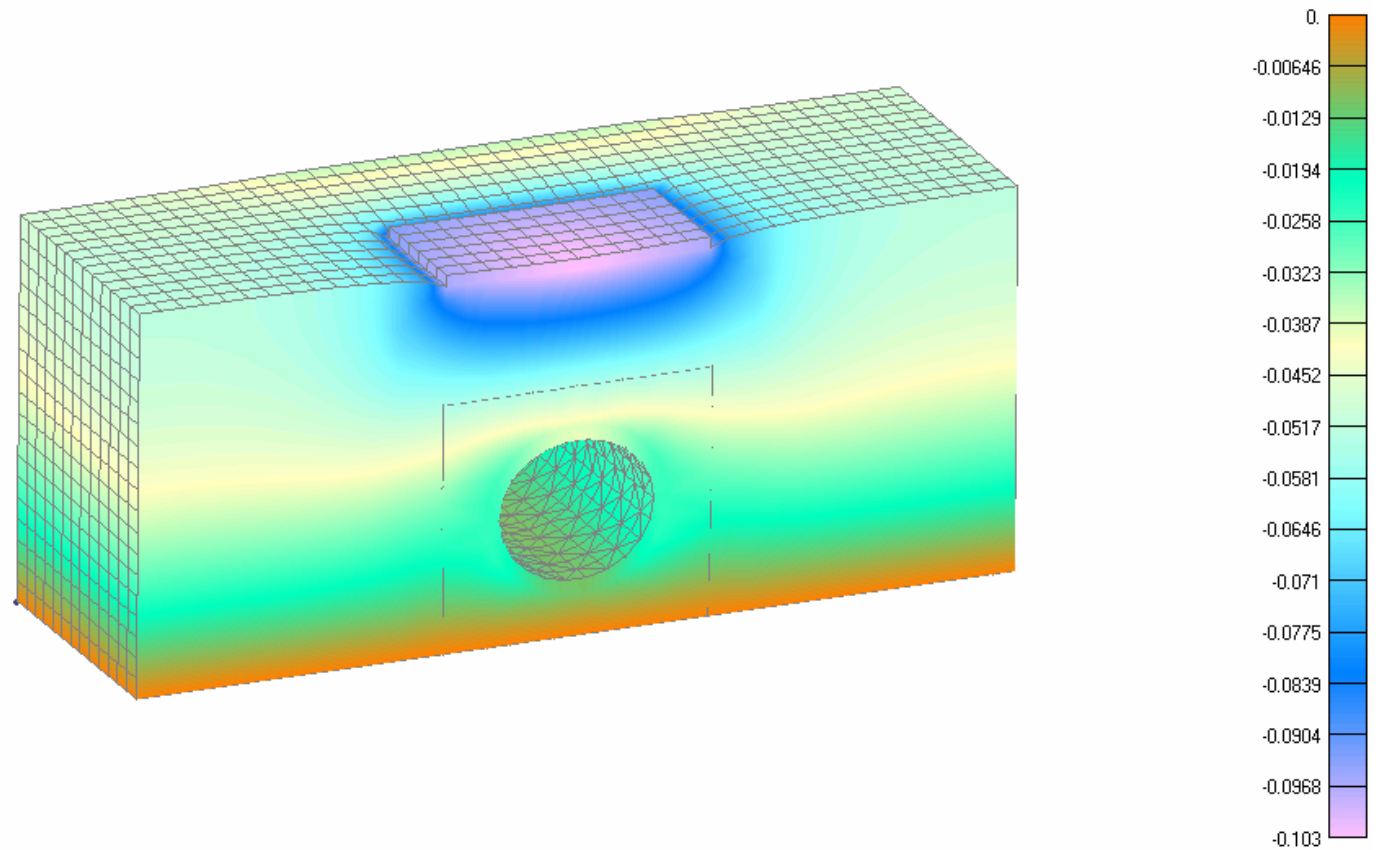

Figure 5.28: Soil-pipe deformation contours for the 8-inch pipe with a trench width ratio of 2 under a $2000 \mathrm{lb}$ plate load 


\subsection{Soil stresses due to plate loading}

The following figures show the vertical stresses at the centerline under plate loading. Each figure contains results corresponding to a vertical load of 1,000 lb (4,448 N), 2,000 lb $(8,896 \mathrm{~N})$, and 3,000 $\mathrm{lb}(13,344 \mathrm{~N})$. Figure 5.29 shows the location of pressure cell at which the vertical stresses were measured when plate loading was applied. Computed stresses under the plate loading for the 6-inch $(15.2 \mathrm{~cm})$ pipe in cohesive insitu soil and low strength backfill are tabulated in Table A.21 in Appendix A. Figure 5.30 shows the vertical stresses under the 6-inch $(15.2 \mathrm{~cm})$ pipe. The numerical data compare well with experimental data at high trench width ratio $\left(\mathrm{N}_{\mathrm{r}}\right)$. The numerical results for vertical stresses compare well with experimental measurements for the 6-inch $(15.2 \mathrm{~cm})$ pipe in cohesive insitu soil with high strength backfill material as shown in Figure 5.31. Again the experimental results for the 6-inch $(15.2 \mathrm{~cm})$ pipe under loose insitu soil and low strength backfill compare well with the finite element results at high trench width ratio $\left(\mathrm{N}_{\mathrm{r}}\right)$ as shown in Figure 5.32. For the 8-inch $(20.3 \mathrm{~cm})$ pipe under cohesive insitu soil and low strength backfill the numerical values compare well with experimental data corresponding to the plate load of 3,000 lb $(13,344 \mathrm{~N})$ as shown in Figure 5.33. For the 8-inch $(20.3 \mathrm{~cm})$ pipe under cohesive insitu soil with high strength backfill material, the experimental stresses did not compare well with numerical stresses as shown in Figure 5.34. The experimental data for the 8 -inch $(20.3 \mathrm{~cm})$ pipe under loose insitu soil and low strength backfill compare well with finite element data as shown in Figure 5.35. Figure 5.36 shows the vertical stress contours for the 8 -inch $(20.3 \mathrm{~cm})$ pipe under the plate load of 2,000 $\mathrm{lb}$ $(8,896 \mathrm{~N})$.

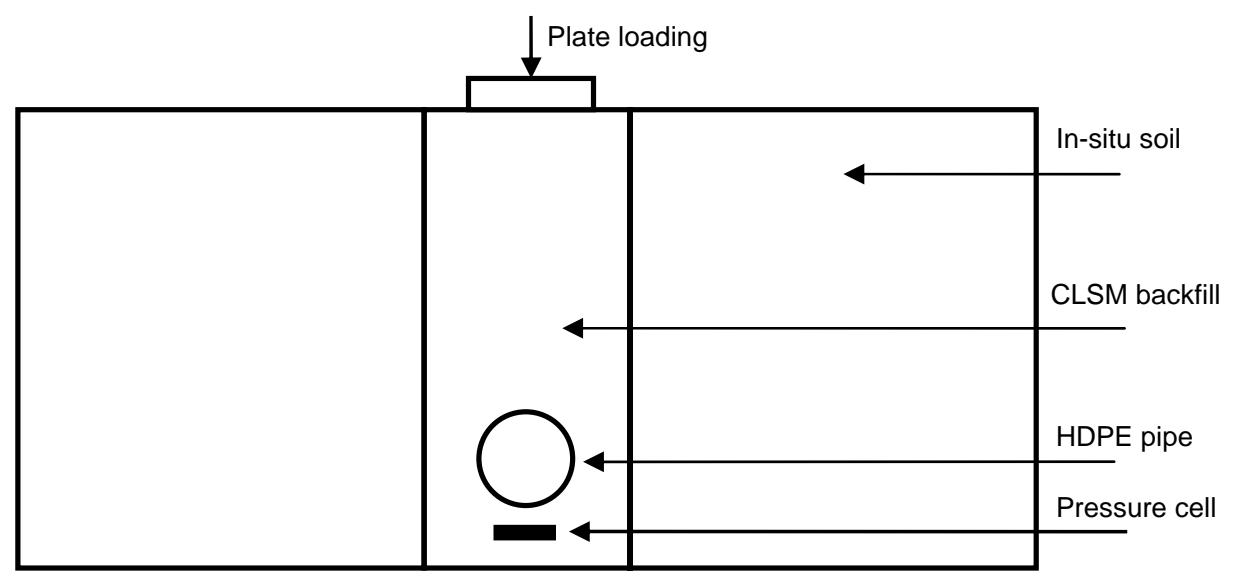

Figure 5.29: Location of pressure cell under the centerline of the pipe 

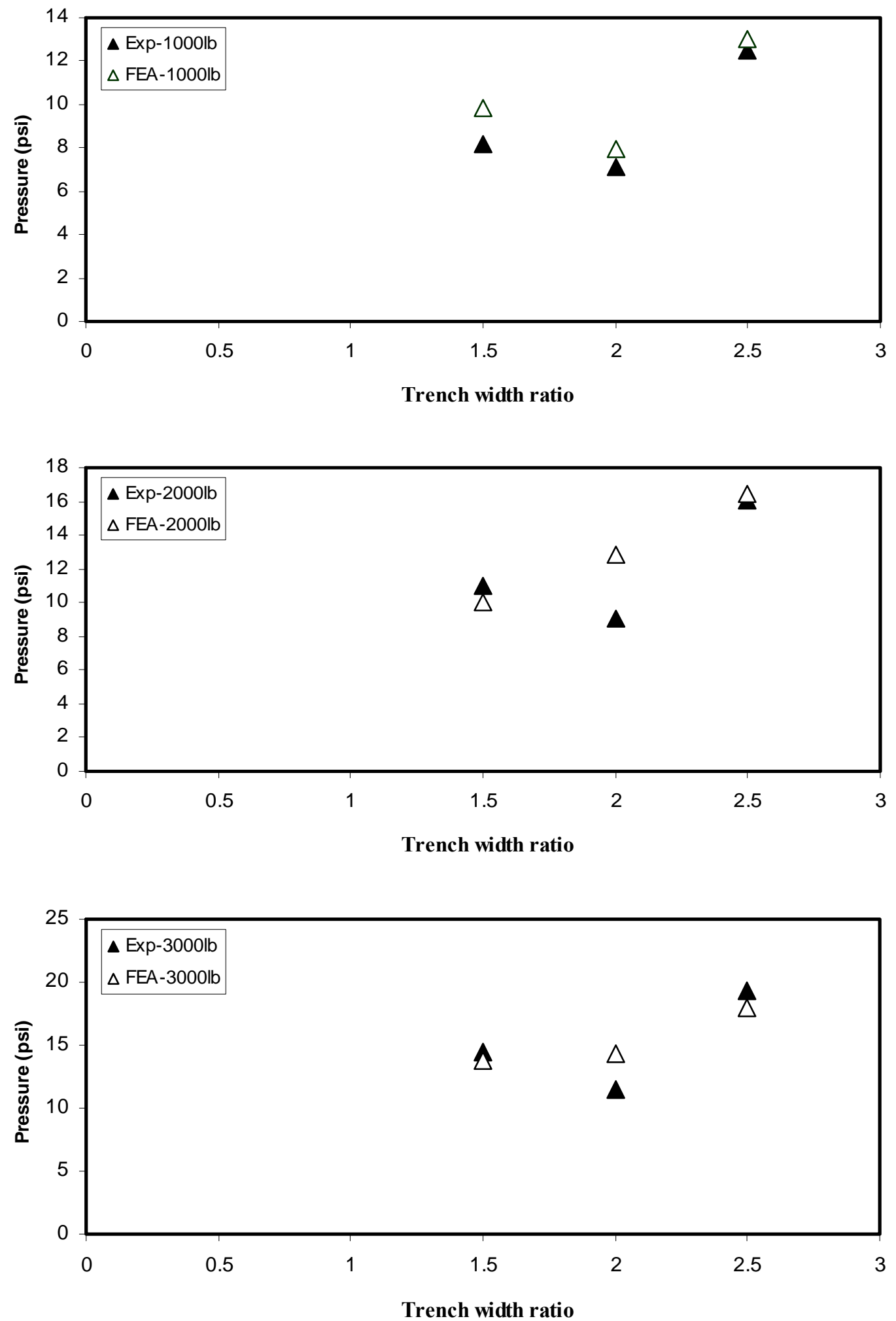

Figure 5.30: Stresses under plate loading of the 6-inch pipe in cohesive insitu soil with low strength backfill 

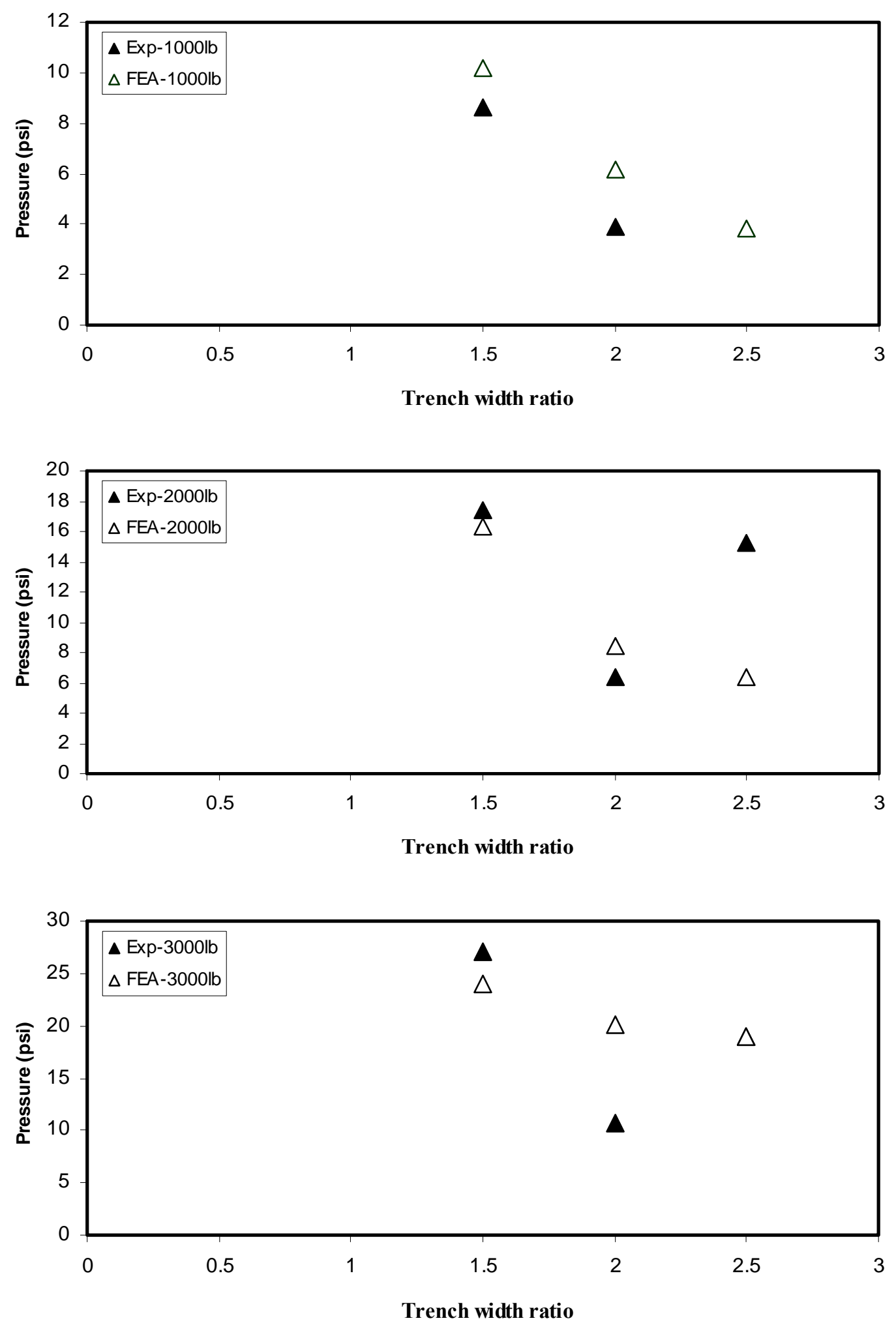

Figure 5.31: Stresses under plate loading of the 6-inch pipe in cohesive insitu soil with high strength backfill 

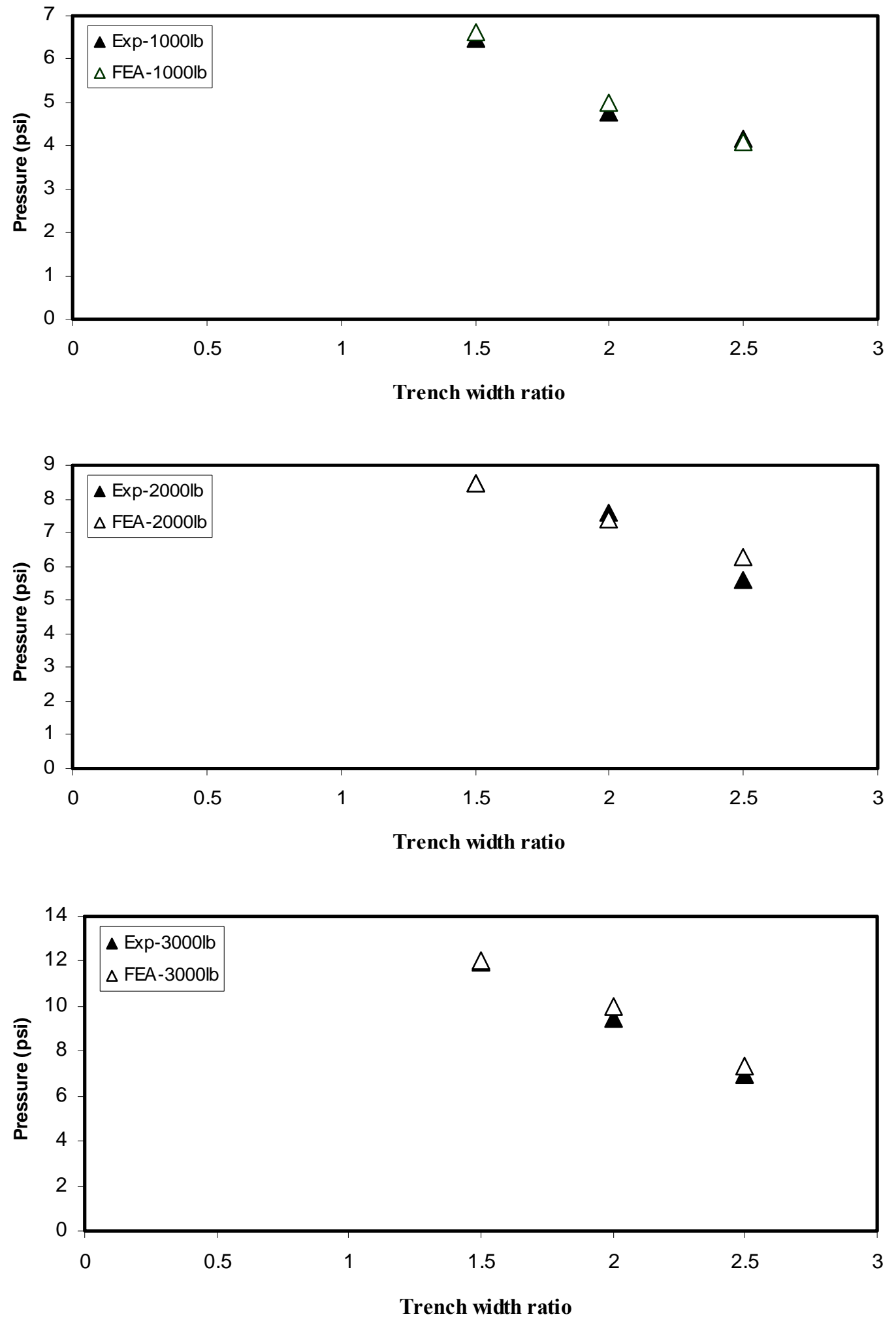

Figure 5.32: Stresses under plate loading of the 6-inch pipe in loose insitu soil with low strength backfill 

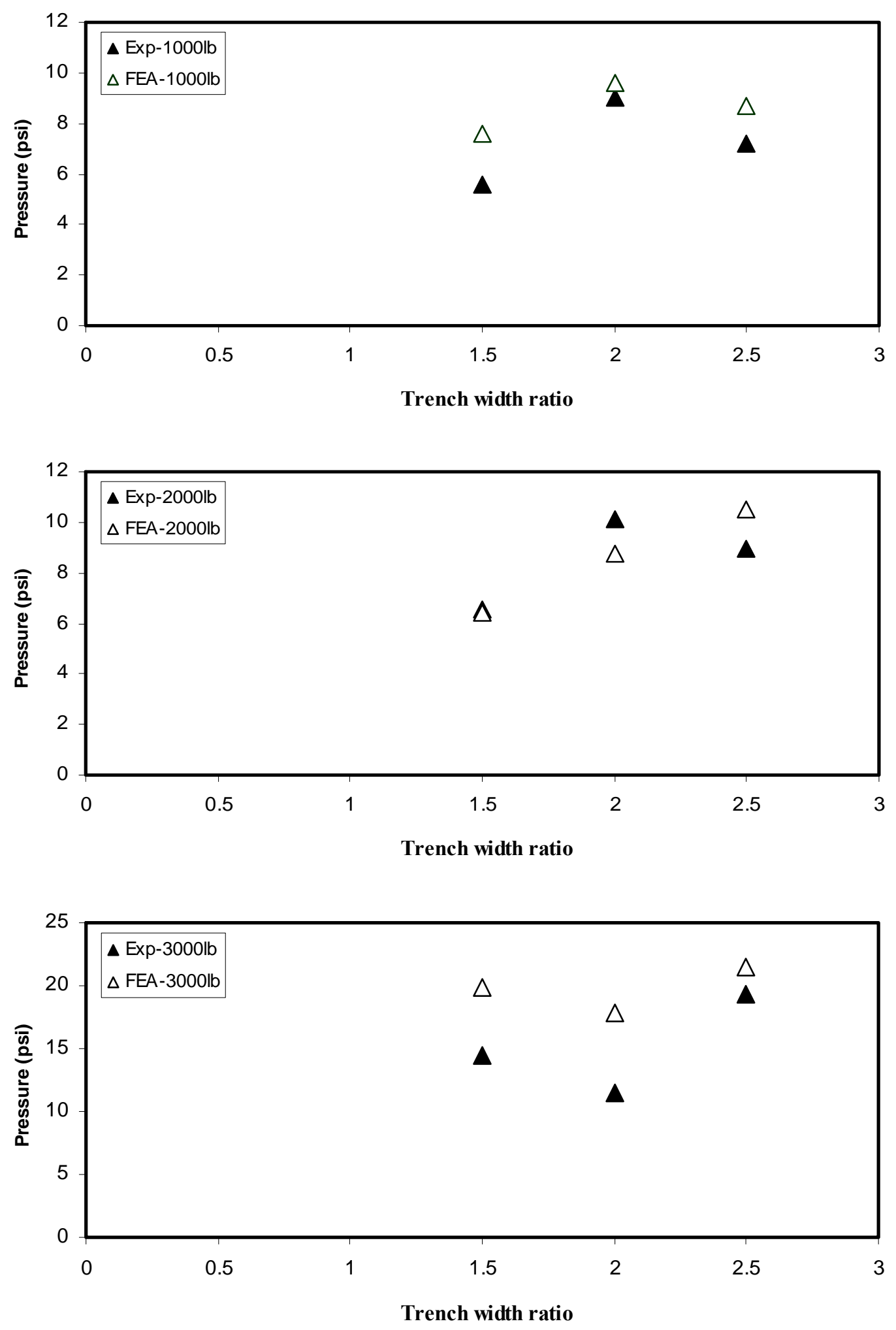

Figure 5.33: Stresses under plate loading of the 8-inch pipe in cohesive insitu soil with low strength backfill 

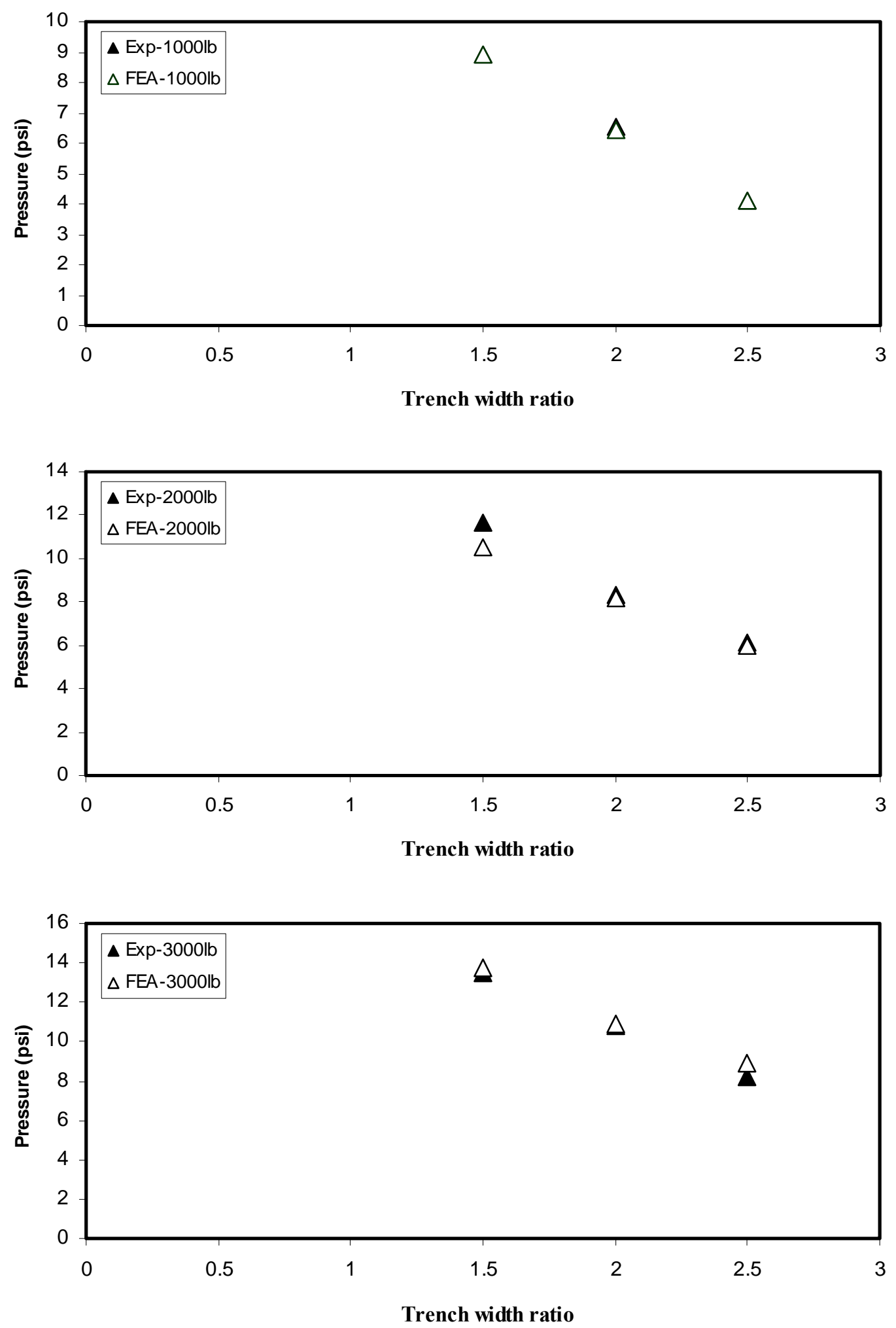

Figure 5.34: Stresses under plate loading of the 8-inch pipe in cohesive insitu soil with high strength backfill 

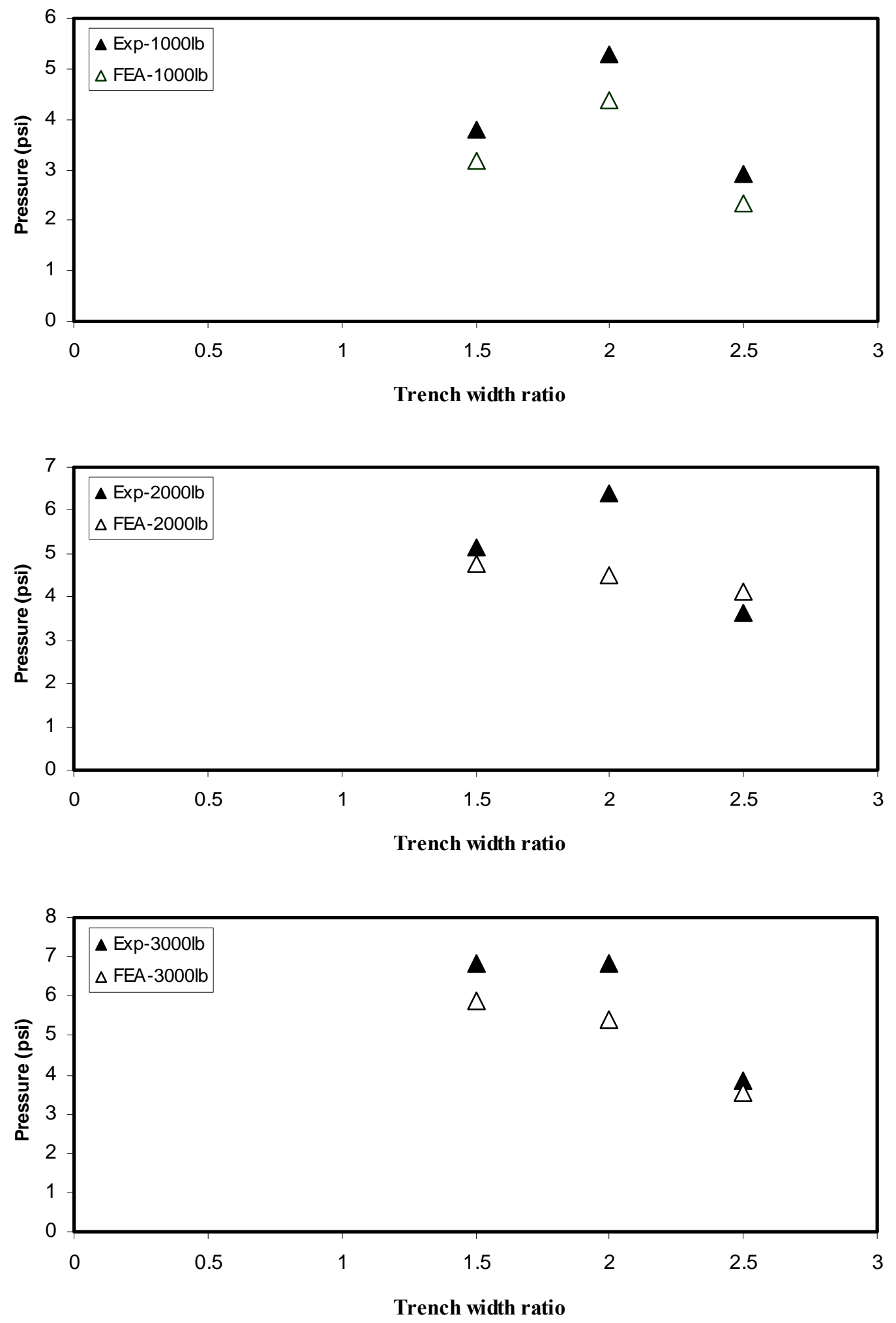

Figure 5.35: Stresses under plate loading of the 8-inch pipe in loose insitu soil with low strength backfill 


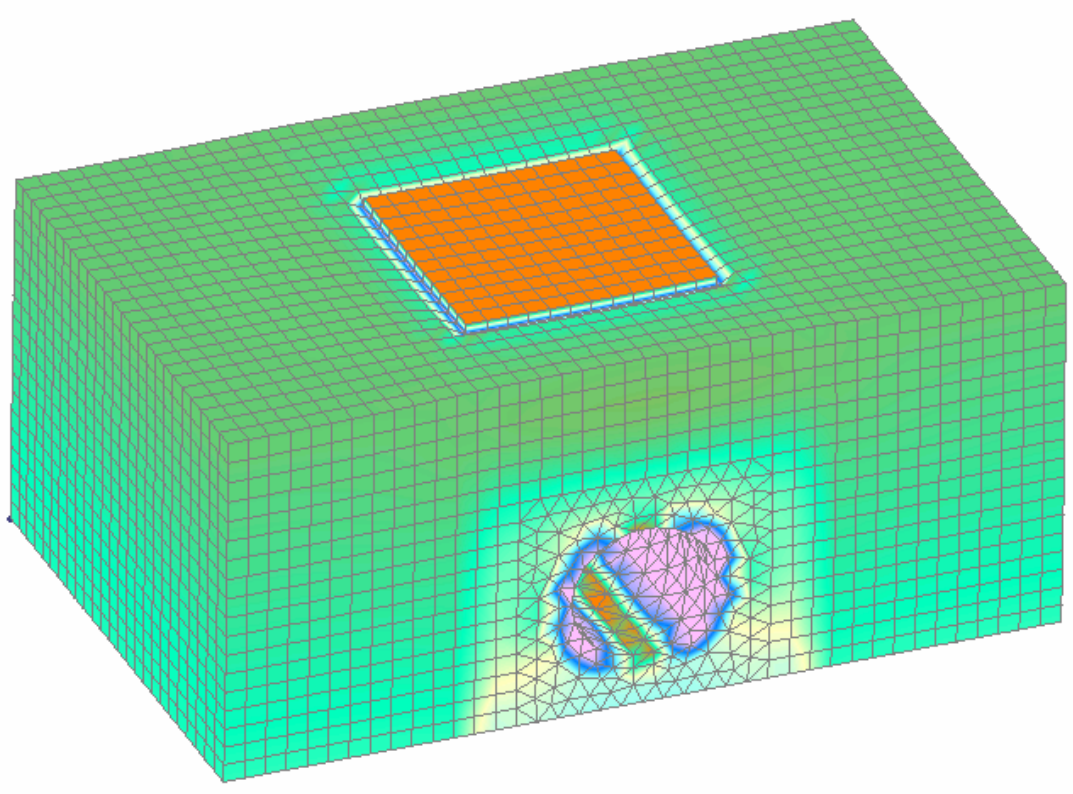

${ }^{2} .938$
0.938
-0.125
-1.188
$\cdot 2.25$
-3.313
-4.375
-5.438
-6.5
-7.563
-8.625
-9.688
-10.75
-11.81
-12.88
-13.94
-15
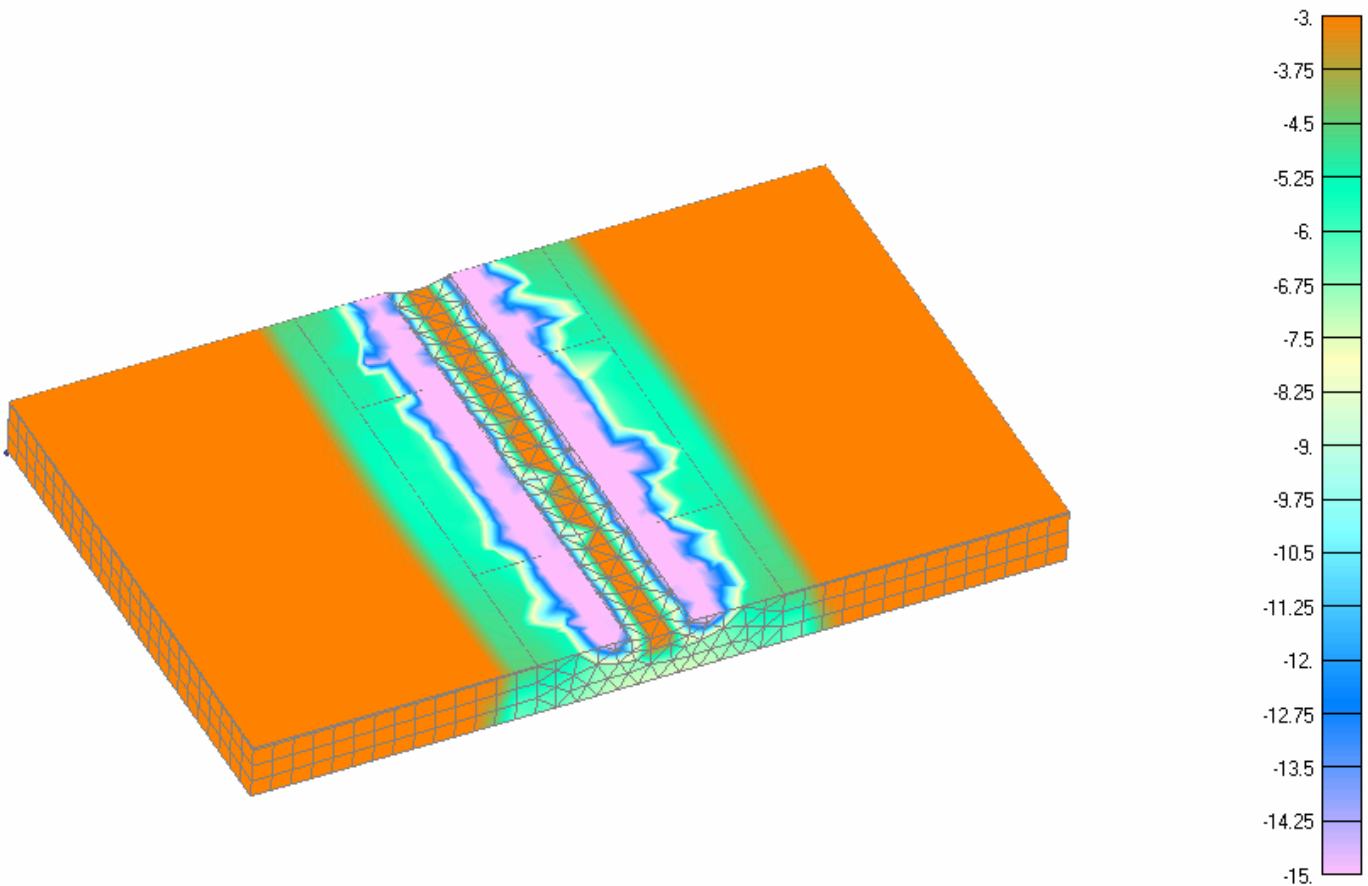

Figure 5.36: Vertical stress contours for the 8-inch pipe with trench width ratio 2 under $2000 \mathrm{lb}$ plate loading 


\section{CHAPTER 6}

\section{NUMERICAL RESULTS UNDER FIELD CONDITIONS}

\subsection{Introduction}

Large diameter high density polyethylene (HDPE) pipes have been frequently used under roadways in place of short-span bridges and culverts due to its cost efficiency and chemical resistance. The literature on the long-term performance of large diameter flexible pipes under field conditions is limited. A few authors have published reports on the long-term performance of buried thermoplastic pipes. The long-term performance of 24-inch $(61 \mathrm{~cm})$ HDPE pipes under a $100 \mathrm{ft}(30.48 \mathrm{~m})$ high embankment was evaluated as reported in the literature (Hashash and Selig, 1990). In a different study (Sargand and Masada, 2000), the field performance of HDPE pipes with a nominal diameter of 42inches $(107 \mathrm{~cm})$ subjected to a $52 \mathrm{ft}(15.85 \mathrm{~m})$ high soil fill was monitored for a duration of 1 year. It was observed that the horizontal deflections were stabilized within 40 days, but the vertical deflections took much longer time to stabilize. It was concluded that the vertical soil pressure measured at the crown and invert decreased slightly, while the lateral soil pressure measured at the spring line increased with time. The field performance of 60-inch $(152 \mathrm{~cm})$ diameter HDPE pipes subjected to $20 \mathrm{ft}(6.10 \mathrm{~m})$ and $40 \mathrm{ft}(12.20 \mathrm{~m})$ high embankment fills was evaluated for about 2 years as reported in the literature (Sargand and Masada, 2004). A significant conclusion drawn from the study was that the long-term performance of the HDPE pipes under constant soil fill loading is affected more by stress relaxation than by creep.

\subsection{Numerical results for HDPE pipes at 20 feet depth}

In this section, numerical results on the structural response of 18 -inch $(45.7 \mathrm{~cm})$ and 24-inch $(61 \mathrm{~cm})$ diameter pipes buried at a depth of $20 \mathrm{ft}(6.10 \mathrm{~m})$ are presented. The pipes were subjected to HS-20 surface load. An HS-20 load consists of a tire pressure of 105 psi applied on a rectangular strip of 22 inch $\times 7$ inch $(56 \mathrm{~cm} \times 18 \mathrm{~cm})$ as shown in Figure 6.1 (Watkins, 1999). Linear elastic finite element analyses were performed by using solid elements in order to evaluate long term structural performance. Analyses were also performed for 5 year and 50 year old 18 -inch $(45.7 \mathrm{~cm})$ and 24 -inch $(61 \mathrm{~cm})$ pipes. 
Table B.1 in Appendix B and Figure 6.2 below show the variation of pipe deflection with time for the 18-inch $(45.7 \mathrm{~cm})$ pipe. Results show that the pipe deflections do not meet the failure criteria. In general a 5\% change in pipe diameter is commonly assumed as the failure condition for HDPE pipes (Moser, 1990). However, in this study a limit of 4\% change in pipe diameter was assumed as the pipe failure criteria because of the potential damages caused during installation of pipes under field conditions. Table 6.2 and Figure 6.3 show the variation of pipe deflection with time for the 24-inch $(61 \mathrm{~cm})$ diameter pipe buried at a depth of 20 feet $(6.1 \mathrm{~m})$. Figure 6.4 below shows the contours of vertical displacements around the 24 -inch $(61 \mathrm{~cm})$ pipe buried at a 20 foot $(6.1 \mathrm{~m})$ depth. Figure 6.5 represents the Von Misses stress contours around the 24-inch $(61 \mathrm{~cm})$ pipe buried at a depth of 20 feet $(6.10 \mathrm{~m})$.

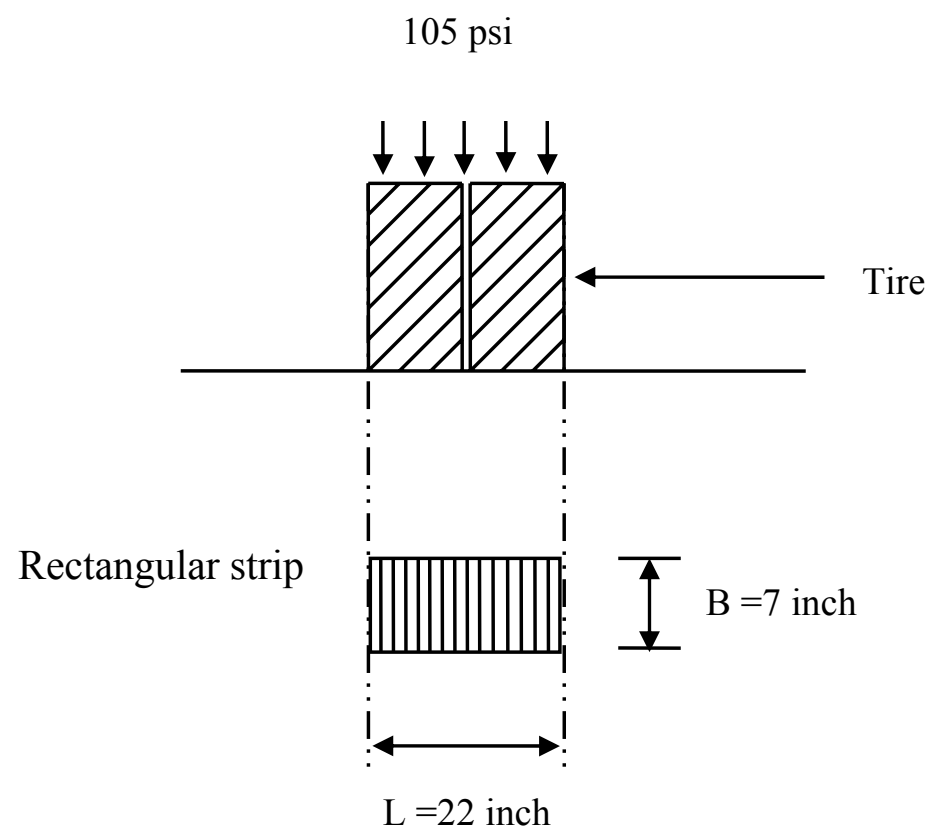

Figure 6.1: HS-20 truck load configuration 


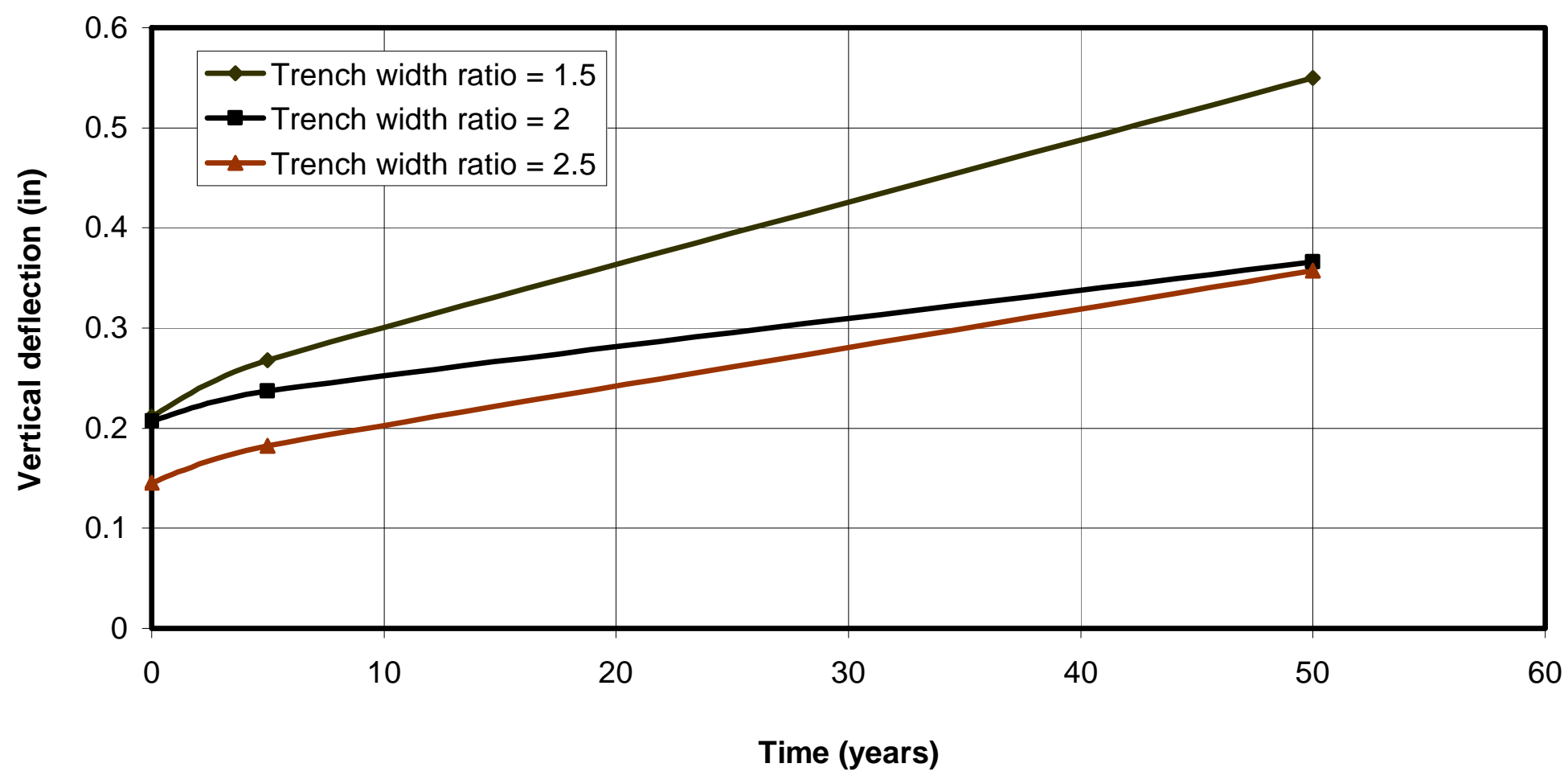

Figure 6.2: Variation of vertical pipe deflection with time for the 18-inch pipe at 20 feet depth 


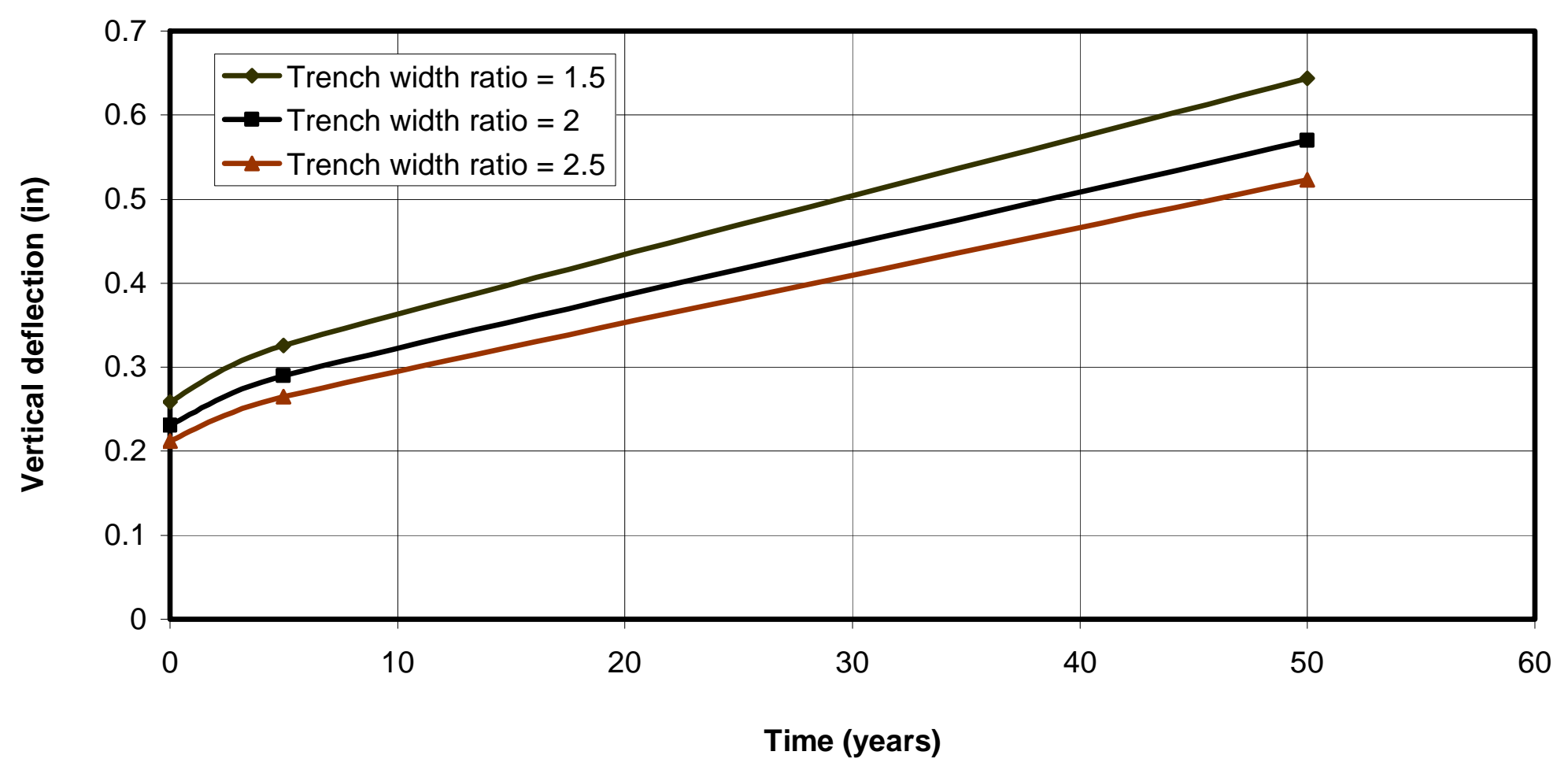

Figure 6.3: Variation of vertical pipe deflection with time for the 24-inch pipe at 20 feet depth 

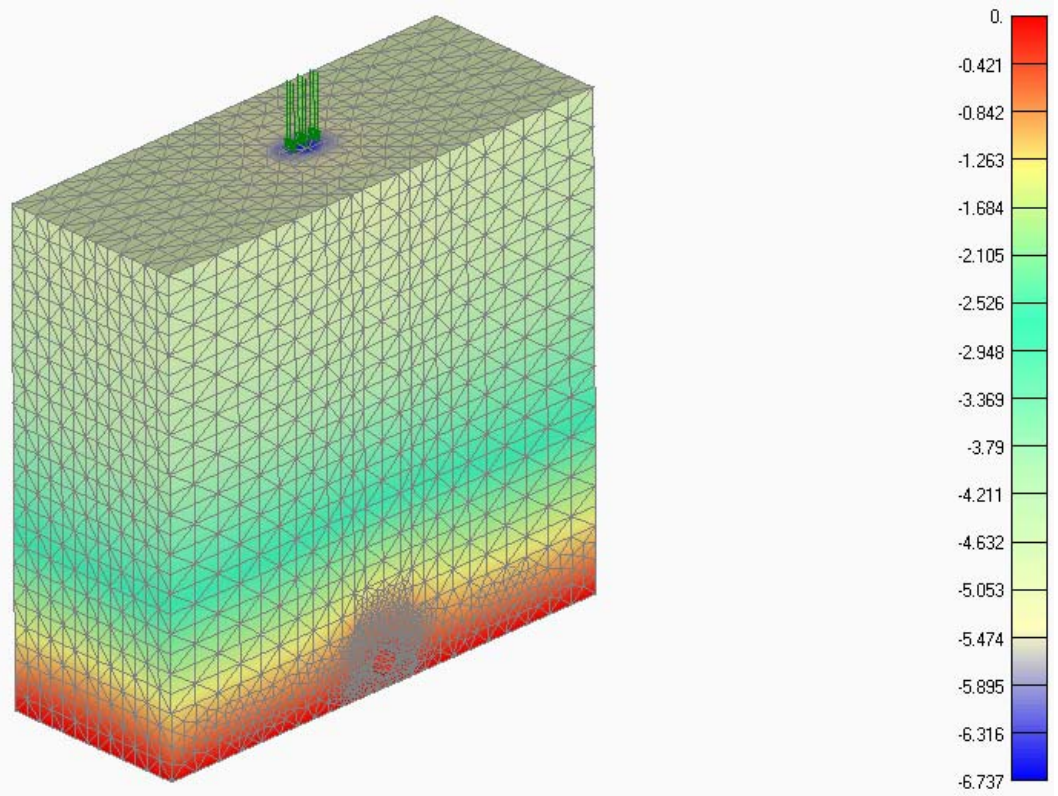

Figure 6.4: Vertical displacements of the 24-inch pipe at 20 feet depth

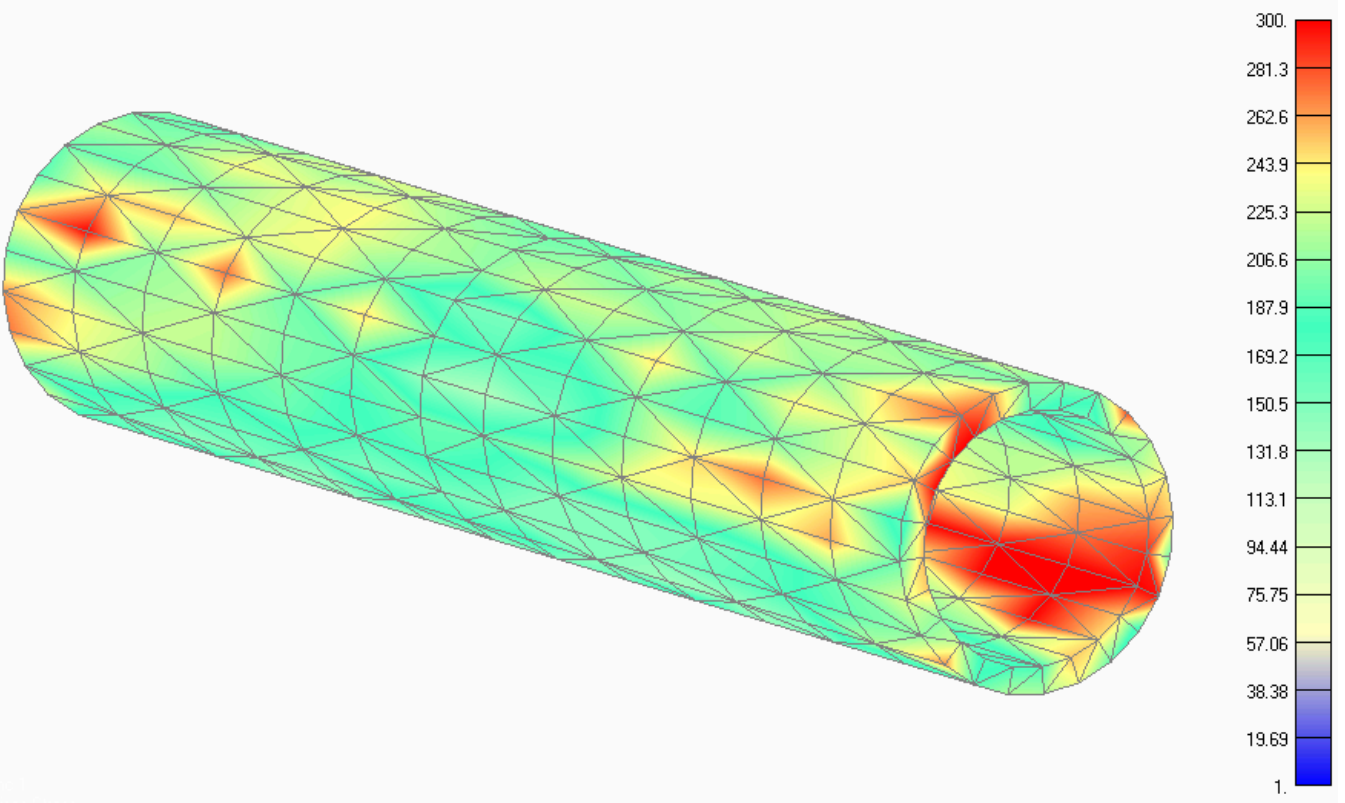

Figure 6.5: Solid Von Misses Stress contours of the 24-inch HDPE pipe at 20 feet 
Numerical results show that the maximum vertical deflection of HDPE pipes under 20 feet $(6.1 \mathrm{~m})$ depth occurs for a trench width ratio equal to 1.5 . Further analyses were carried out for the 18 -inch $(45.7 \mathrm{~cm})$ and the 24 -inch $(61 \mathrm{~cm})$ pipes with a trench width ratio equal to 1.5 , but with increased depth. Finite element models were generated for pipes buried at depths of 20 feet, 30 feet, 40 feet, 50 feet and 60 feet. The analyses were done at 0 years and 50 years as described in section 4.6 of chapter 4 . Two different models were generated for each case, one considering an interface and the other without an interface as shown in Figure 6.6 and Figure 6.7. The interface elements were placed between the native soil and the backfill soil material as shown in the Figures 6.6 and 6.7. The interface acts as a thin wall whose stiffness property was assumed to be $1 / 10^{\text {th }}$ of that of the insitu soil.

The properties used in the analysis of 18-inch $(45.7 \mathrm{~cm})$ and 24-inch $(61 \mathrm{~cm})$ HDPE pipes are presented in the Table 6.1. Figure 6.8 and Figure 6.9 show the variation of deflection as a function of depth for the 18 -inch $(45.7 \mathrm{~cm})$ and 24-inch $(61 \mathrm{~cm})$ pipes at 0 years and 50 years with a trench width ratio equal to 1.5. Both the models, one with interface and the other without interface were considered. These figures indicate that the interface properties have a significant influence on the pipe deflection. In fact, both 18inch $(45.7 \mathrm{~cm})$ and 24-inch $(61 \mathrm{~cm})$ pipes meet the failure criterion beyond a burial depth of $60 \mathrm{ft}(18.3 \mathrm{~m})$ at a trench width ratio $\left(\mathrm{N}_{\mathrm{r}}\right)$ equal to 1.5 when the interface properties were incorporated into the analysis. The numerical values corresponding to the Figure 6.8 and Figure 6.9 are tabulated in Table B.3 and Table B.4 in Appendix B.

Deflections as a function of trench width ratio $\left(\mathrm{N}_{\mathrm{r}}\right)$ for the 18 -inch $(45.7 \mathrm{~cm})$ pipe at 0 years and 50 years considering interface properties are shown in Figures 6.10 to 6.13. The numerical values corresponding to Figures 6.10 to 6.13 are tabulated in Table B.5 in Appendix B. Deflections as a function of trench width ratio $\left(\mathrm{N}_{\mathrm{r}}\right)$ for the 24-inch $(61 \mathrm{~cm})$ pipe at 0 years and 50 years considering interface properties are shown in Figures 6.14 to 6.17. The numerical values corresponding to Figures 6.14 to 6.17 are tabulated in Table B.6 in Appendix B. 


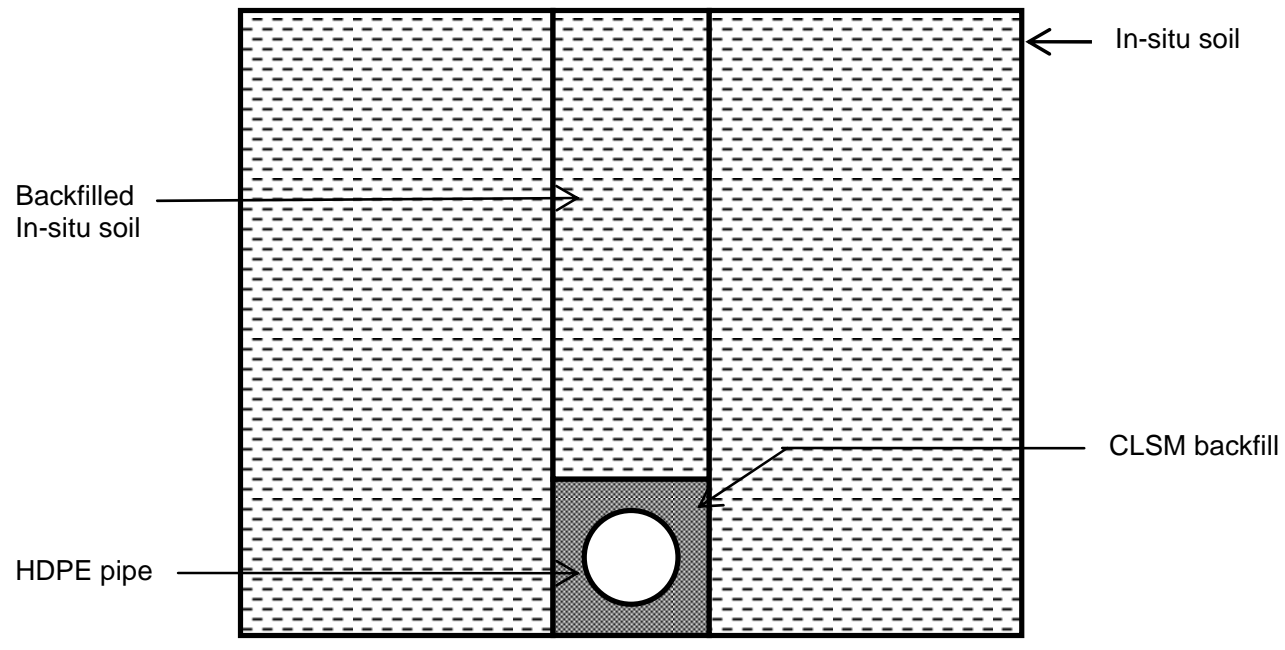

Figure 6.6: Buried pipe model without Interface

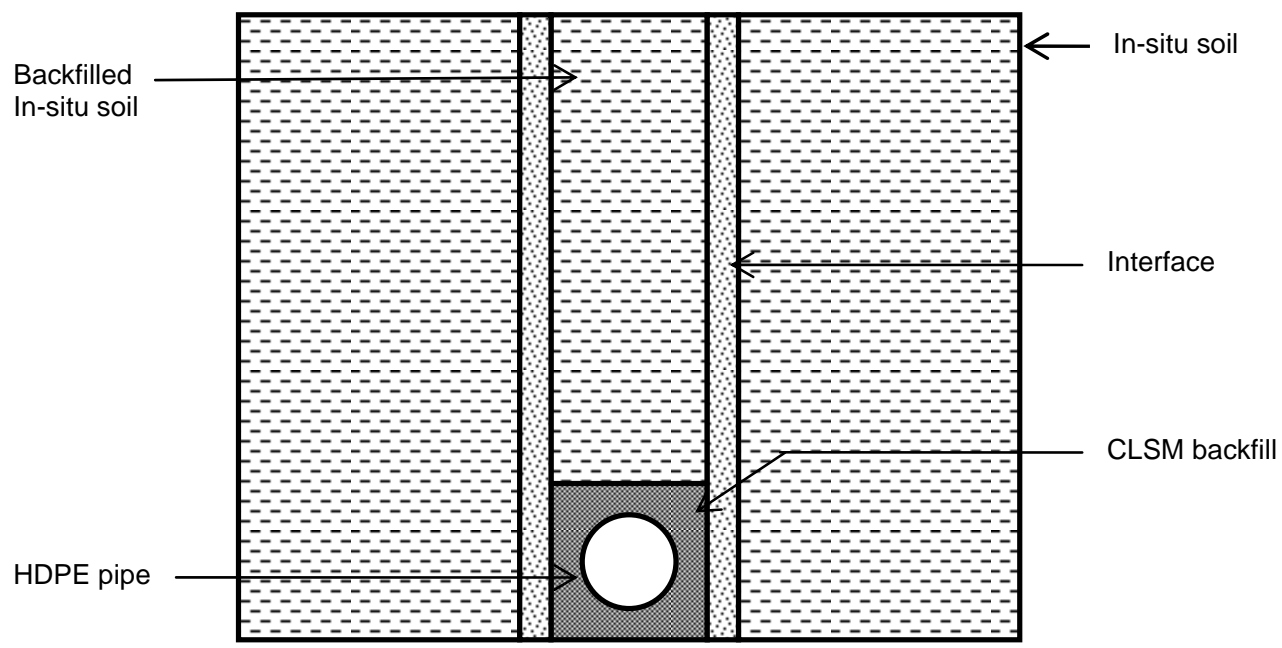

Figure 6.7: Buried pipe model with Interface 
Table 6.1: Properties used in the finite element analysis

\begin{tabular}{|c|c|c|c|c|c|c|c|c|}
\hline \multirow{2}{*}{ Parameters } & \multicolumn{2}{|c|}{$\begin{array}{c}\text { Pipe properties at } 0 \\
\text { years }\end{array}$} & \multicolumn{2}{|c|}{$\begin{array}{c}\text { Pipe properties at } 50 \\
\text { years }\end{array}$} & \multirow{2}{*}{$\begin{array}{c}\text { Backfill } \\
\text { properties }\end{array}$} & \multirow{2}{*}{$\begin{array}{c}\text { Fill } \\
\text { properties }\end{array}$} & \multirow{2}{*}{$\begin{array}{l}\text { Insitu soil } \\
\text { properties }\end{array}$} & \multirow{2}{*}{$\begin{array}{l}\text { Interface } \\
\text { properties }\end{array}$} \\
\hline & 18 inch & 24 inch & 18 inch & 24 inch & & & & \\
\hline $\begin{array}{c}\text { Elastic } \\
\text { Modulus } \\
\text { (E) psi }\end{array}$ & 65,312 & 77,317 & 24,646 & 29,176 & 1800 & 1000 & 1000 & 100 \\
\hline $\begin{array}{l}\text { Poisson's } \\
\text { ratio (v) }\end{array}$ & 0.35 & 0.35 & 0.35 & 0.35 & 0.3 & 0.3 & 0.3 & 0.3 \\
\hline $\begin{array}{c}\text { Mass density } \\
\text { (p) } \\
\text { Pcf }\end{array}$ & 60 & 60 & 60 & 60 & 140 & 125 & 125 & 125 \\
\hline
\end{tabular}




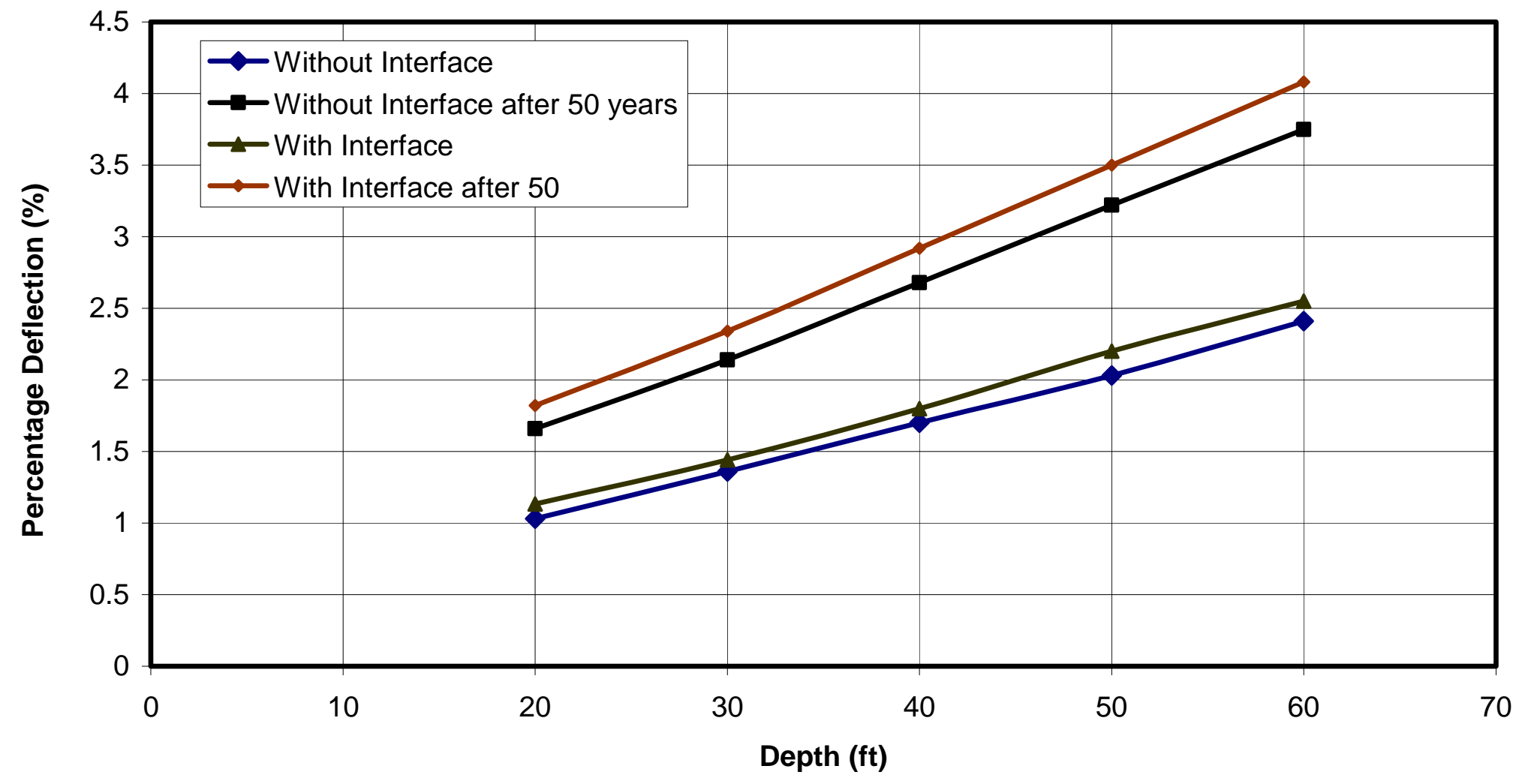

Figure 6.8: Variation of pipe deflection with depth for the 18-inch HDPE pipe 


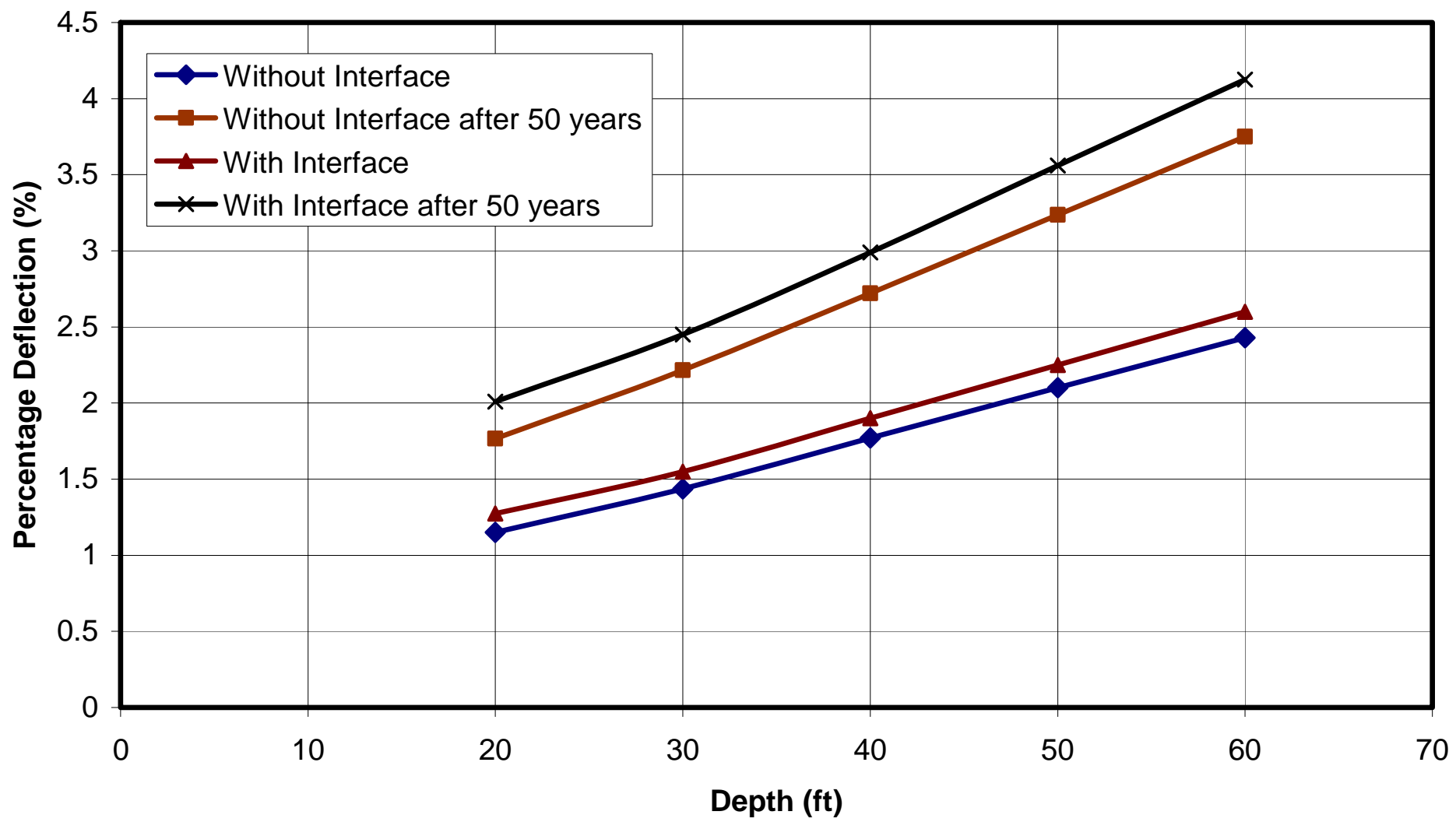

Figure 6.9: Variation of pipe deflection with depth for the 24-inch HDPE pipe 


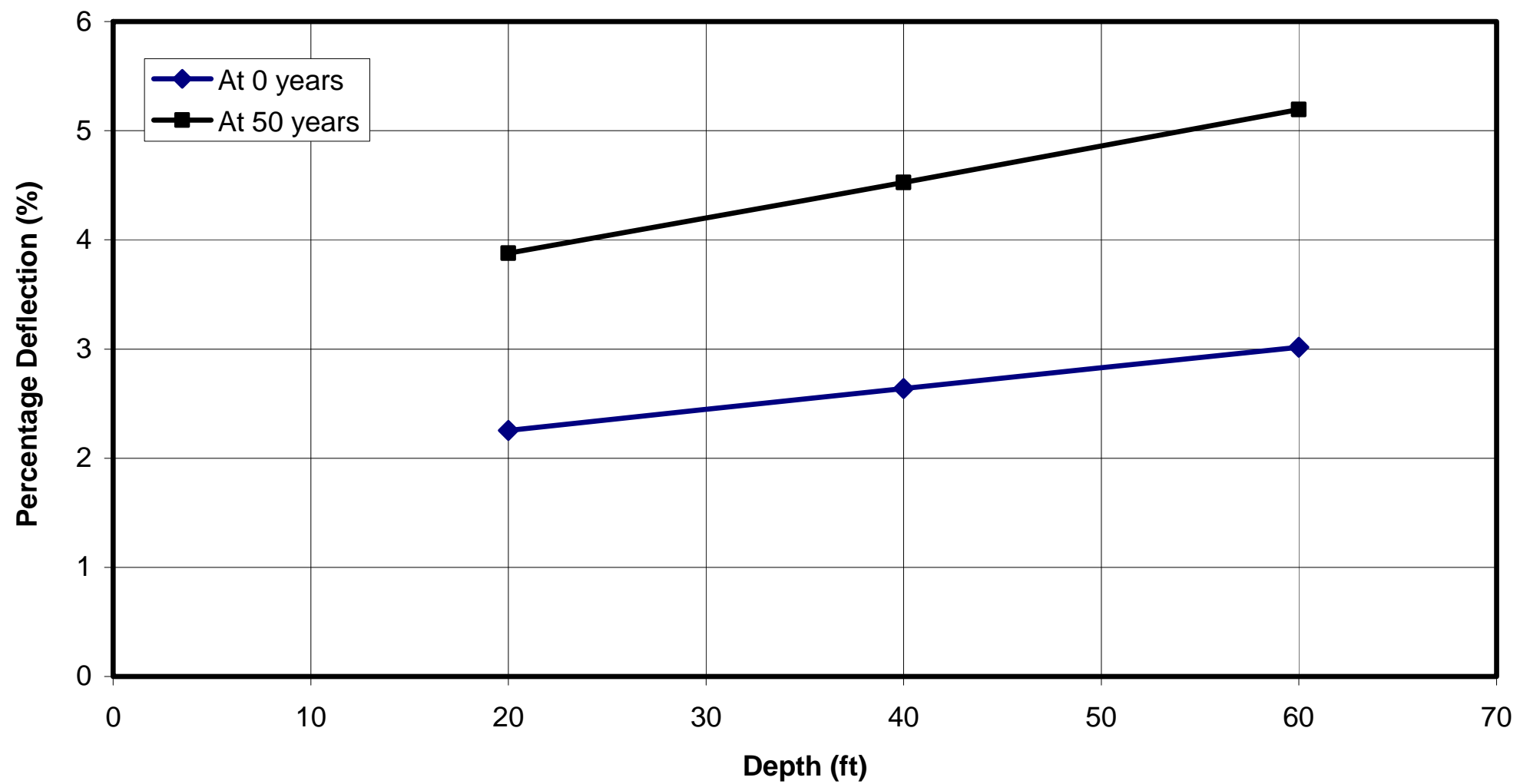

Figure 6.10: Variation of deflection with depth of the 18-inch HDPE pipe with interface for a trench width ratio, $\left(\mathrm{N}_{\mathbf{r}}\right)=\mathbf{1 . 5}$ 


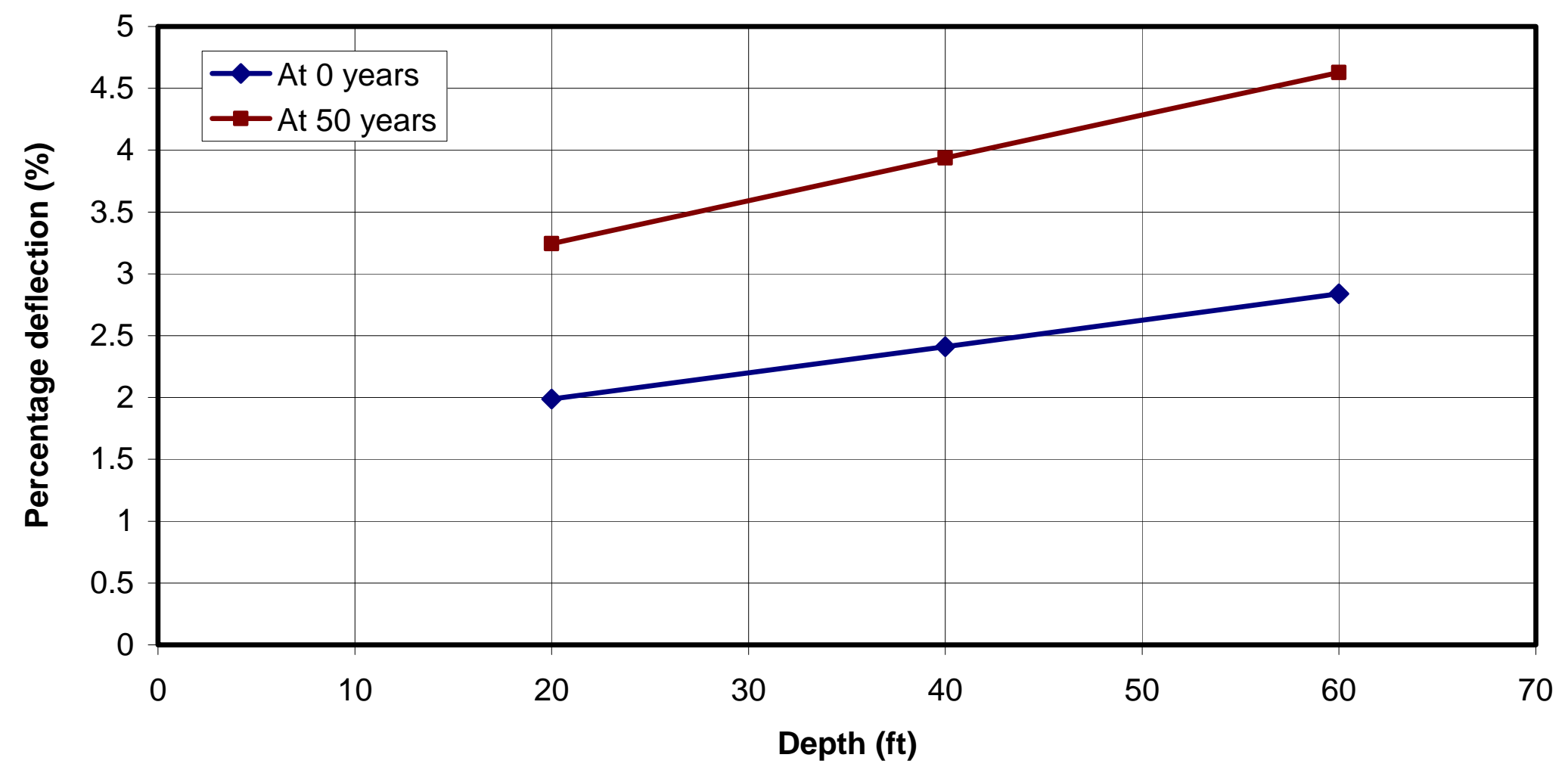

Figure 6.11: Variation of deflection with depth of the 18-inch HDPE pipe with interface for a trench width ratio, $\left(\mathrm{N}_{\mathrm{r}}\right)=2$ 


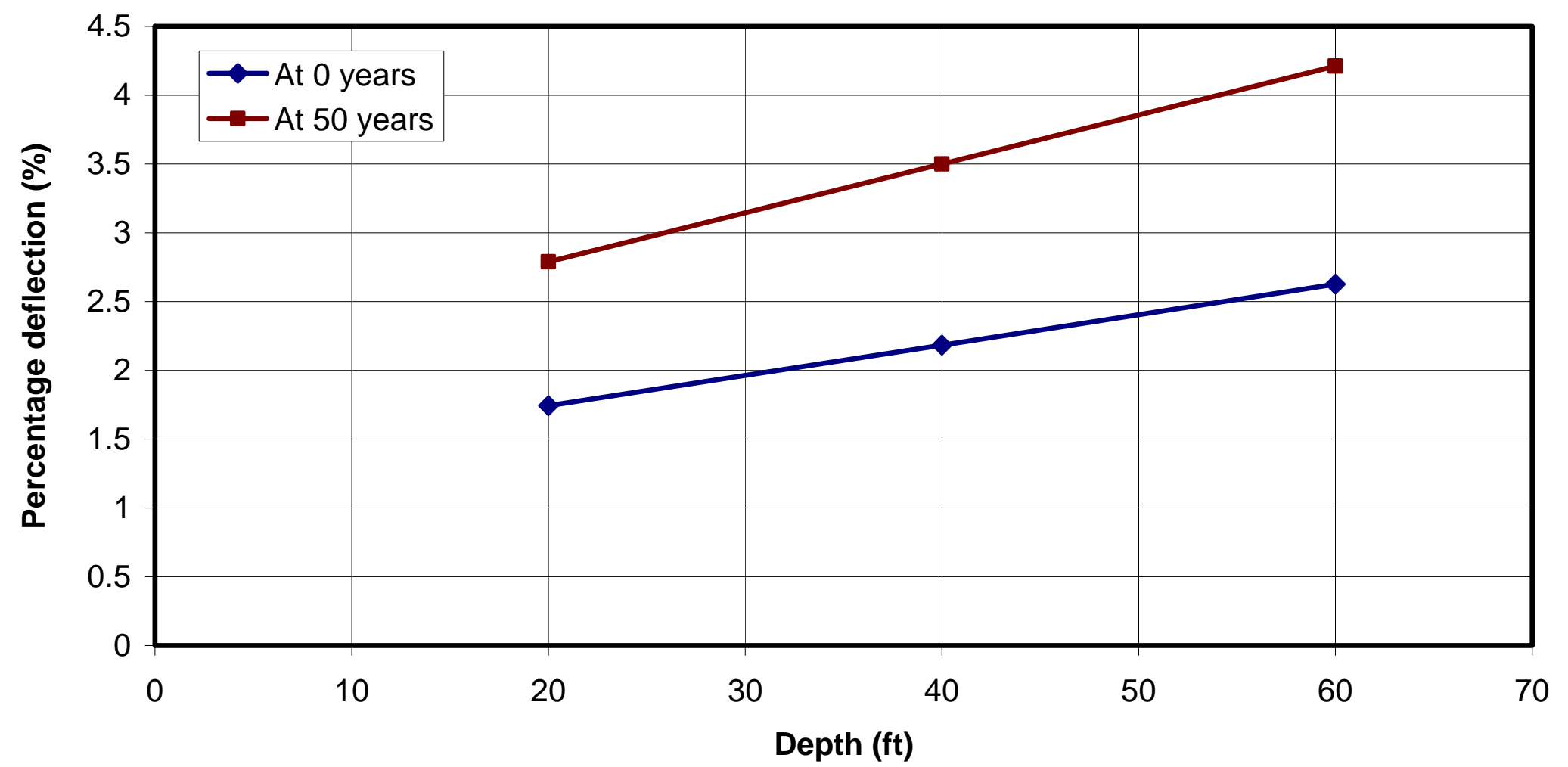

Figure 6.12: Variation of deflection with depth of the 18-inch HDPE pipe with interface for a trench width ratio, $\left(\mathrm{N}_{\mathrm{r}}\right)=\mathbf{2 . 5}$ 


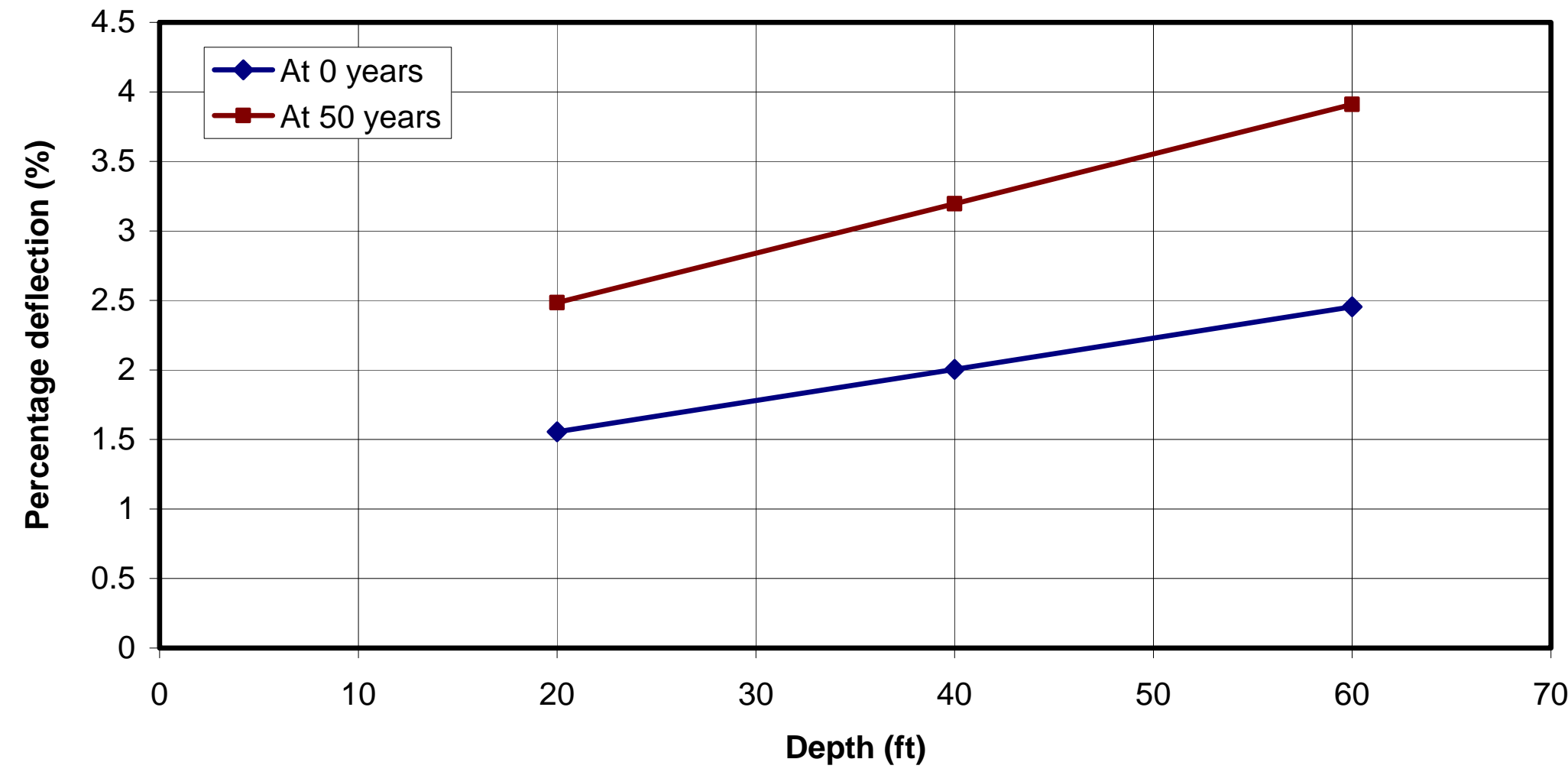

Figure 6.13: Variation of deflection with depth of the 18-inch HDPE pipe with interface for a trench width ratio, $\left(\mathbf{N}_{\mathrm{r}}\right)=\mathbf{3}$ 


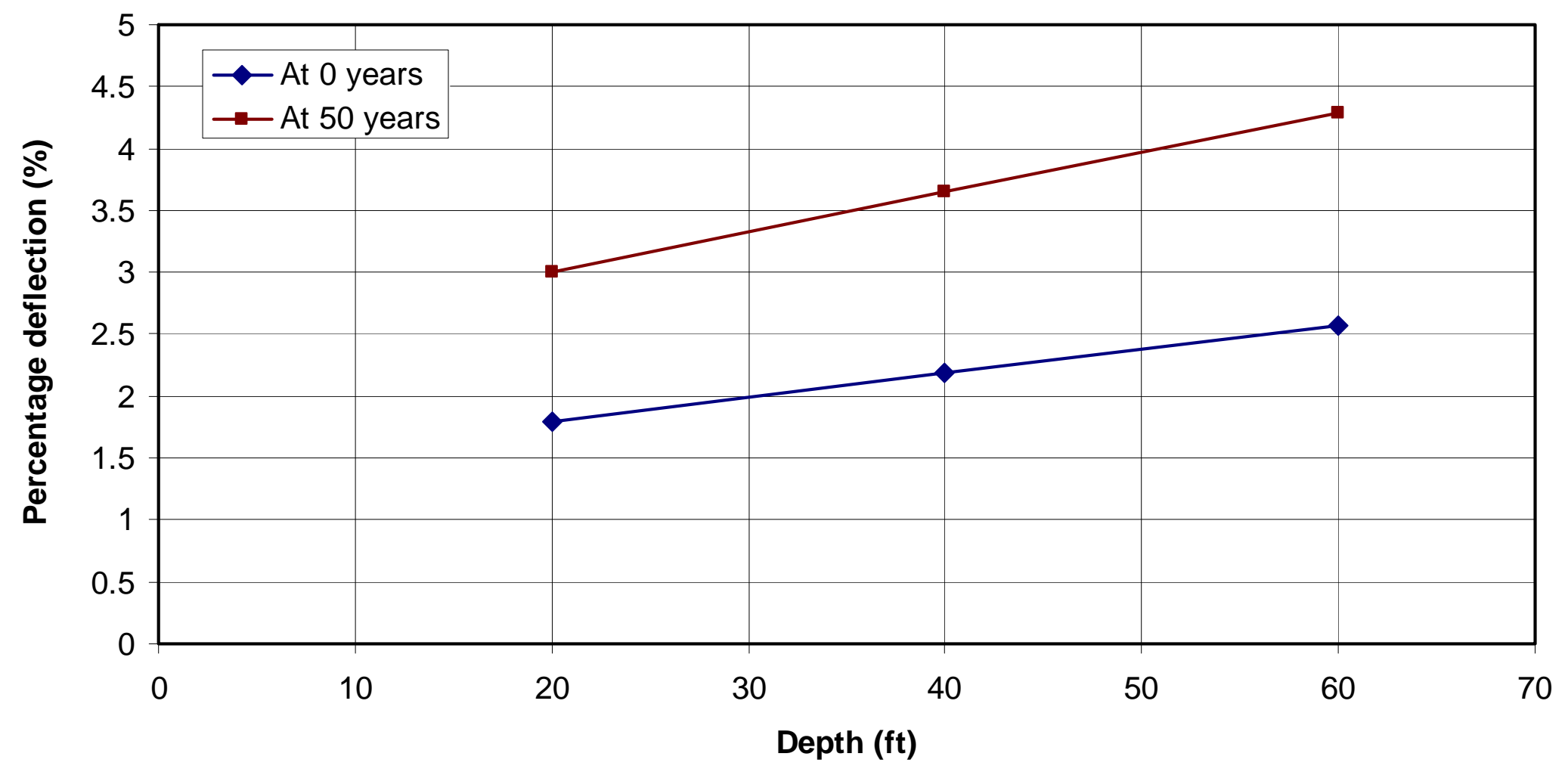

Figure 6.14: Variation of deflection with depth of the 24-inch HDPE pipe with interface for a trench width ratio, $\left(\mathrm{N}_{\mathrm{r}}\right)=\mathbf{1 . 5}$ 


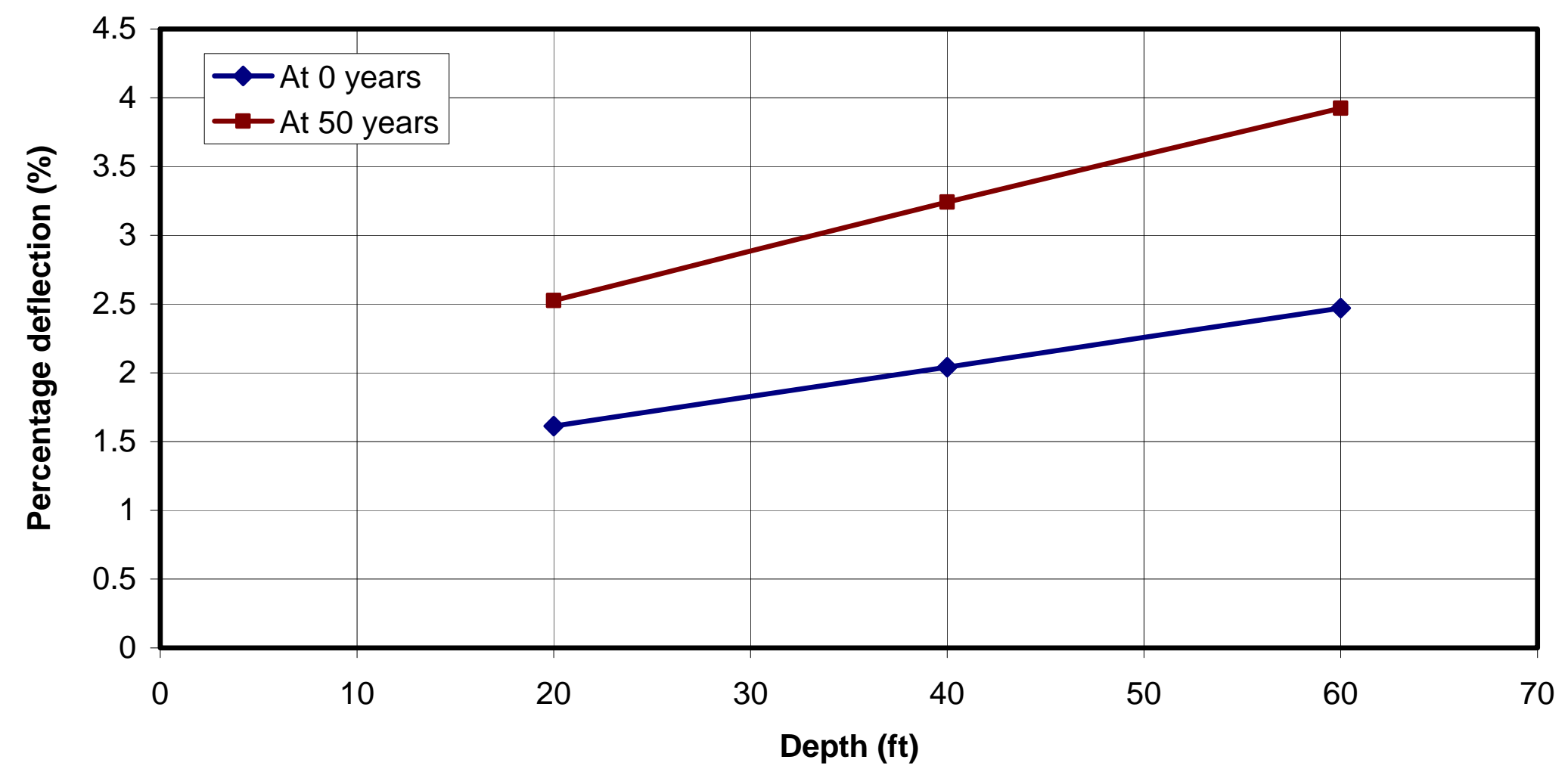

Figure 6.15: Variation of deflection with depth of the 24-inch HDPE pipe with interface for a trench width ratio, $\left(\mathrm{N}_{\mathrm{r}}\right)=\mathbf{2}$ 


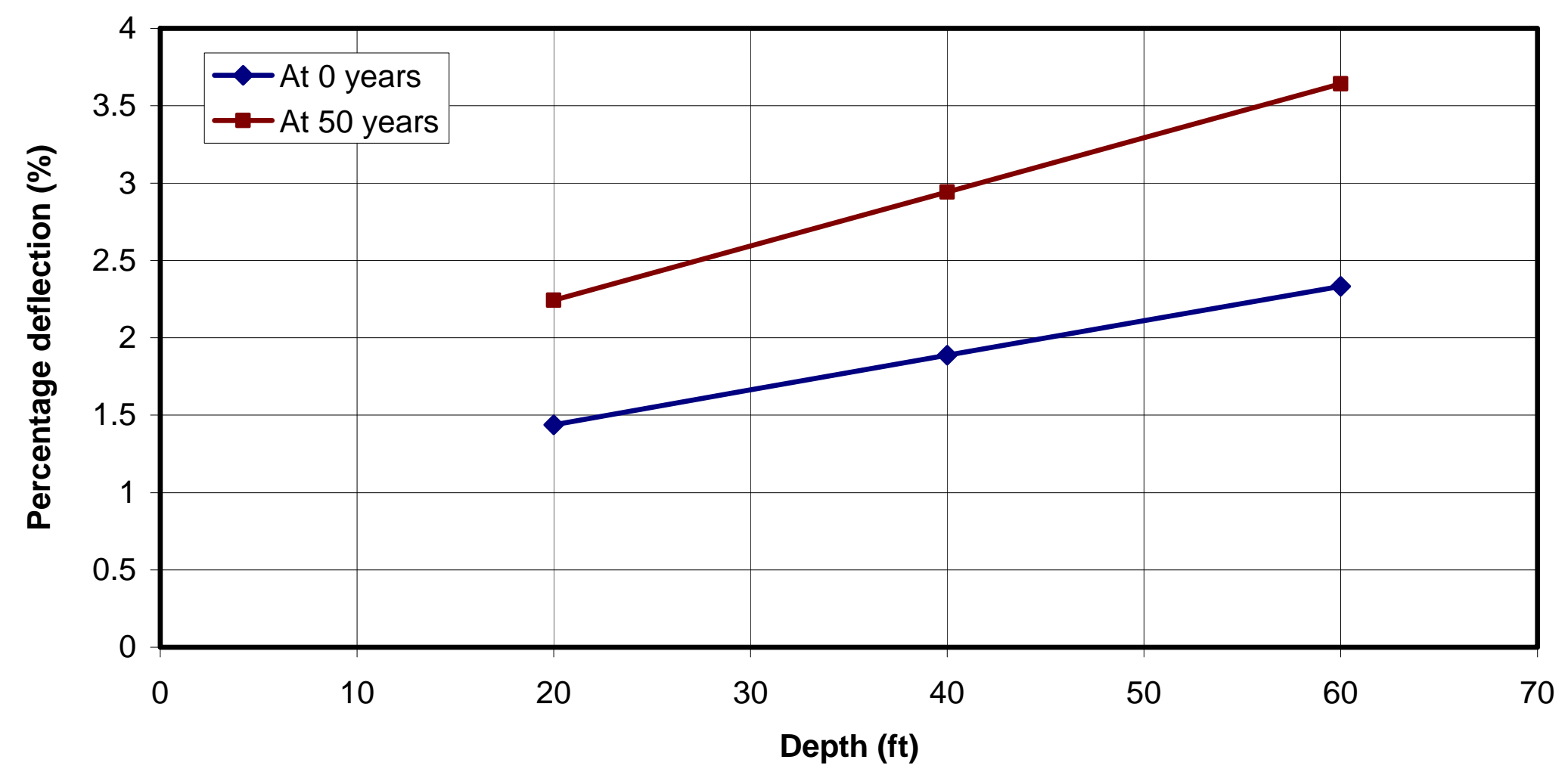

Figure 6.16: Variation of deflection with depth of the 24-inch HDPE pipe with interface for a trench width ratio, $\left(\mathrm{N}_{\mathrm{r}}\right)=\mathbf{2 . 5}$ 


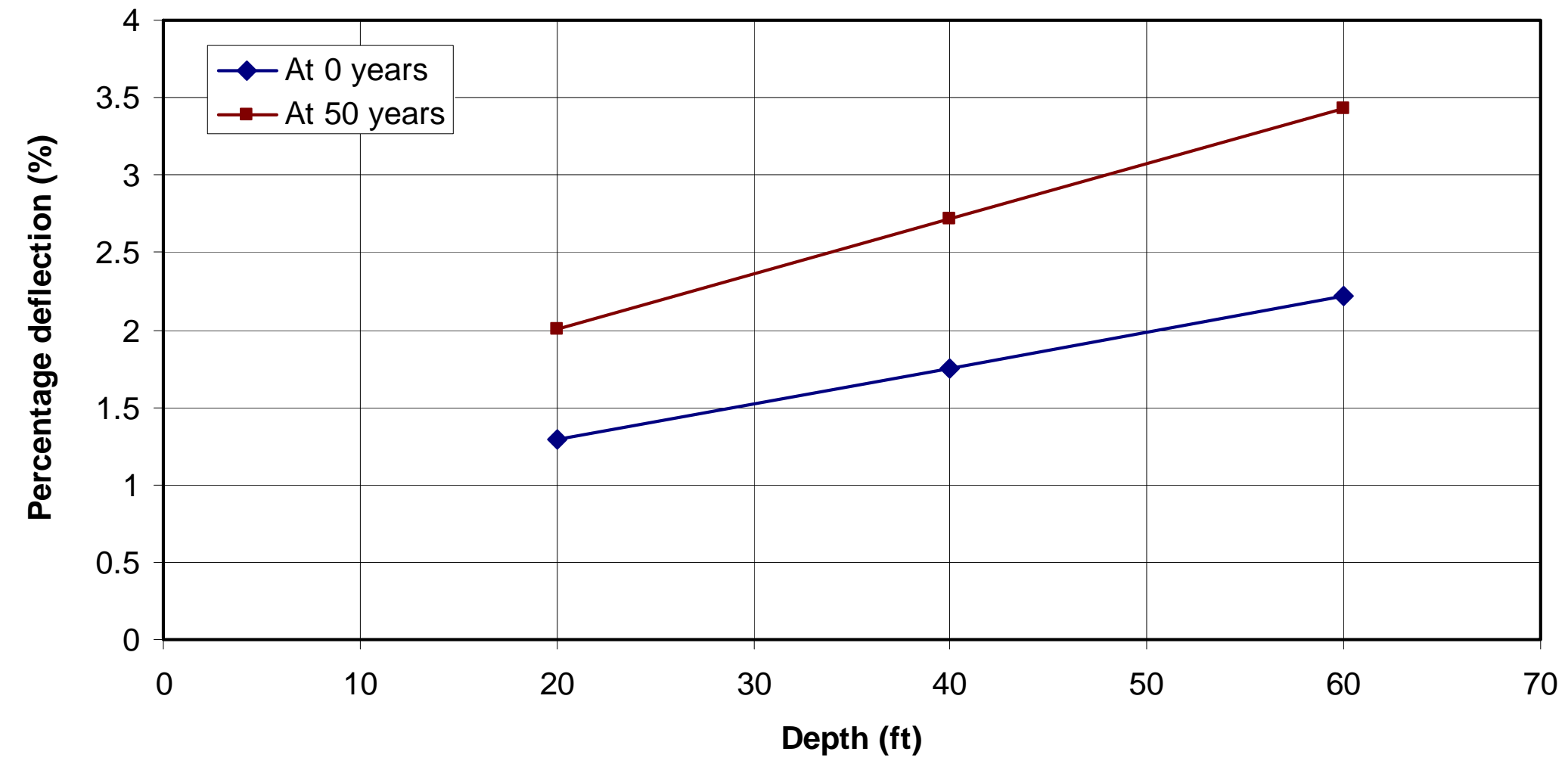

Figure 6.17: Variation of deflection with depth of the 24-inch HDPEpipe with interface for a trench width ratio, $\left(\mathrm{N}_{\mathrm{r}}\right)=3$ 


\section{CHAPTER 7 \\ SUMMARY AND CONCLUSIONS}

\subsection{Summary}

The objective of this research work was to investigate the influence of various parameters on the structural performance of HDPE pipes under field and laboratory conditions by using the finite element method. This research emphasizes the influence of trench width on the long term structural performance of HDPE pipes with different CLSM mixtures as backfill material. The stiffness properties of CLSM backfill materials were back calculated from experimental data obtained under various trench width ratios. The stiffness properties of HDPE pipes were calculated based on the data provided by the pipe manufacturer. Finite element models of HDPE pipes with varying trench widths were developed for laboratory conditions. The experimental variables included: trench width, pipe diameter, in-situ soil strength, backfill strength, and external loading. The numerical results were compared with that of the experimental data. In addition to modeling laboratory conditions, finite element models for 18 -inch $(45.7 \mathrm{~cm})$ and 24 -inch $(61 \mathrm{~cm})$ diameter pipes were developed for field conditions. The depth of burial was varied between $20 \mathrm{ft}(6.1 \mathrm{~m})$ to $60 \mathrm{ft}(18.2 \mathrm{~m})$. An HS-20 load acting at the ground surface was considered in addition to the body forces (weight of soil). In order to evaluate the long-term structural performance of HDPE pipes, finite element analysis was carried out up to 50 years.

\subsection{Conclusions}

The following conclusions can be made based on the results presented in this report.

The percentage deflections of 6-inch $(15.3 \mathrm{~cm})$ and 8-inch $(20.2 \mathrm{~cm})$ diameter pipes under laboratory loading conditions were found to be in safe limits defined by the structural performance of the manufacturer's specifications.

The computed values of deflections and stresses for 6-inch $(15.3 \mathrm{~cm})$ and 8-inch $(20.2 \mathrm{~cm})$ diameter HDPE pipes are in good agreement with experimental values under surcharge loading. 
The percentage deflections of the 18-inch $(45.7 \mathrm{~cm})$ and 24-inch $(61 \mathrm{~cm})$ diameter pipes indicate that the interface properties have a significant influence on pipe performance under field conditions. Interface elements tend to increase the pipe deflections.

Both the 18-inch $(45.7 \mathrm{~cm})$ and 24-inch $(61 \mathrm{~cm})$ HDPE pipes do not meet the failure criterion up to a burial depth of $50 \mathrm{ft}(15.2 \mathrm{~m})$ with a trench width ratio $\left(\mathrm{N}_{\mathrm{r}}\right)$ equal to 1.5. In other words, the finite element analysis shows that the trench width ratio can be reduced to 1.5 without causing pipe failure up to a burial depth of $50 \mathrm{ft}(15.2 \mathrm{~m})$.

The centerline soil stresses and deflections decrease when the trench width ratio is increased.

> The finite element analysis of buried pipes shows that the interface properties have a significant influence on the computed pipe deflections and the stress distribution around buried pipes. Both the deflections and the stresses around the pipe with interface elements are higher than those computed in the model without interface elements.

The results show that narrow trench widths can be successfully used in many cases if the insitu soil strength and the CLSM backfill strength were appropriately accounted for.

\subsection{Recommendations}

Numerical modeling of pipes with different diameters should be performed. This will provide information on the performance of a wide range of buried pipes.

Numerical analyses should be conducted by using even lower strength CLSM backfill. These additional analyses will help to establish relationships between CLSM strength and pipe deflections. 
$>$ Analysis of double-walled HDPE pipes at varying trench width ratios and depths should be performed. This information helps in choosing a single-walled or a double-walled pipe for a particular application considering the cost effectiveness. 


\section{REFERENCES}

ABAQUS version 6.3. (2004). ABAQUS user's manual. Hibbitt, Karlson \& Sorensen, Inc., Pawtucket, RI.

ADS, Inc., Advanced drainage systems: Technical notes [Online]. (2005). Available: http://www.ads-pipe.com/us/en/products/N12IBST.shtml, [6 August 2005].

Ashutosh, S.D., Moore, I.D., and McGrath, T.J. (2002). Evaluation of simplified design methods for buried thermoplastic pipe. Proceedings of the pipeline division specialty conference, August 2-7, Cleveland, Ohio.

ASTM D 1248. (1998). Standard specification for polyethylene plastics extrusion materials for wire and cable. American Standard for Testing Materials.

ASTM D 2412. (2000). Standard test method for determination of external loading characteristics of plastic pipe by parallelplate loading. American Standard for Testing Materials.

ASTM D 2487. (2000). Standard Classification of soils for engineering purposes (Unified soil classification system. American Standard for Testing Materials.

ASTM D 790. (2000). Standard Test Methods for Flexural Properties of Unreinforced and Reinforced Plastics and Electrical Insulating Materials. American Standard for Testing Materials.

ASTM D 2321. (2000). Standard practice for underground installation of thermoplastic pipe for sewers and other gravity-flow applications. American Standard for Testing Materials.

ASTM C150. (2002). Standard specification for Portland cement. American Standard for Testing Materials.

ASTM D 698. (2000). Standard test methods for laboratory compaction characteristics of soil using standard effort. American Standard for Testing Materials.

ASTM D 4832. (2000). Standard test method for preparation and testing of controlled low strength materials test cylinders. American Standard for Testing Materials.

AASHTO M294. (2002). Standard specification for corrugated polyethylene pipe. American Association of State Highway and Transportation Officials.

AWWA (2002). Standard specification for plastic pipes. American water works association. 
Barna, J.A., and White, K. (1998). In-field performance of high-density polyethylene pipe in Ohio. Proceedings of the third conference on structural performance of pipes, Mitchell, G.F., Sargand, S.M., \& White, K (eds), March 22-24, Athens, Ohio, pp.39-50.

Brachman, R.W.I., Moore, I.D., and Rowe, R.K. (2000). The design of a laboratory facility for evaluating the structural response of small-diameter buried pipe. Canadian Geotechnical Journal. Vol. 37.

Brewer, W. E. (1990). The design and construction of culverts using controlled low strength material-controlled density fill (CLSM-CDF) backfill. Proceedings of the first conference on structural performance of pipes, Sargand, G.F., Mitchell, G.F., \& Hurd, J.O (eds), October 21-23, Columbus, Ohio, pp.109 -118.

Brewer, W. E., and Hurd, J.O. (1993). Controlled low strength material -controlled density fill (CLSM-CDF) as a backfilol around flexible structures. Proceedings of the second conference on structural performance of pipes, Sargand, G.F., Mitchell, G.F., \& Hurd, J.O (eds), March 14-17, Columbus, Ohio, pp.25-34.

Bulson, P.S. (1985). Buried structures: static and dynamic strength. Chapman \& Hall, New York, NY.

CAN/CSA B182.11 (2004). Recommended practice for the installation of thermoplastic drain, strom and sewer pipe and fittings. Canadian standards association.

Chua, K.M. (1986). Time-dependent interaction of soil and flexible pipe. Texas A \& M university.

Chudnovsky, A., Sehanobish, K., and Wu, S. (1999). Methodology for durability analysis of HDPE pipe. Fracture, Design analysis of pressure vessels, PVP-Vol. 388, ASME.

Cook, R.D., Malkus, D.S., Plesha, M.E., and Witt, R.J. (2003). Concepts and applications of finite element analysis. John Wiley \& Sons, Inc., Indianapolis, IN.

Conard, B.E., Lohnes, R.A., Klaiber, F.W., and Wipe, T.J. (1998). Boundary effects on response of polyethylene pipe under simulated live load. Transportation Research Record 1624, No. 98-0588, pp. 196-205.

Crabb, G.I., and Carder, D.R. (1985). Loading tests on buried flexible pipes to validate a new design model. Transportation and road research laboratory. Supplementary report 204. Crowthorne, U.K.

Daniels, L. H. (1990). Structural stability of deflected flexible pipe in a backfilled trench. Structural performance of flexible pipes. Proceedings of the First National Conference on Flexible Pipes. 119-122. 
Desai, C.S. and Siriwardane, H.J. (1984). Constitutive Laws for Engineering Materials, with Special Reference to Geologic Media. Prentice-Hall, Inc., Englewood, New Jersey.

Duncan, J.M., and Chang, C.Y. (1970). Nonlinear analysis of stress and strain in soils. Journal of Soil Mech. and Foundation Division, ASCE, 96 (SM5), pp.1629-1653.

Faragher, E., Rogers, C.D.F., and Fleming, P.R. (1998). Laboratory determination of soil stiffness data for buried plastic pipes. Transportation Research Record 1624, No. 980773, pp. 231-236.

FEMAP version 8.2. (2004). FEMAP user's guide. EDS PLM Solutions, Inc., Exton, PA.

Fleckenstein, L.J., and Allen, D.L. (1993). Field performance report on corrugated polyethylene pipe. Proceedings of the second conference on structural performance of pipes, Sargand, G.F., Mitchell, G.F., \& Hurd, J.O (eds), March 14-17, Columbus, Ohio, pp.67-77.

Goddard, J.B., and Gabriel, L.H. (1998). Relaxation modulus of HDPE: Long term values with short term tests. Proceedings of the third conference on structural performance of pipes, Mitchell, G.F., Sargand, S.M., \& White, K (eds), March 22-24, Athens, Ohio, pp.151.

Gumbel, J.E., and Wilson, J. (1981). Interative design of buried flexible pipes - A fresh approach from basic principles. Groung Engineering, Vol. 14, No. 4, pp. 36-40.

Hashash, N., and Selig, E.T. (1990). Analysis of the performance of a buried high density polyethylene pipe. Proceedings of the second conference on structural performance of pipes, Sargand, G.F., Mitchell, G.F., \& Hurd, J.O (eds), March 14-17, Columbus, Ohio, pp.95-103.

Howard, A.K. (1972). Laboratory load tests on buried flexible pipe. Journal of the American Water Works Association. Vol 64. No.10, pp.655-662.

Linping, Zhao., Beuse, N.M., and Widera, G.E.O. (2001). External pressure testing of 4-inDia high-density polyethylene pipe. Journal of pressure vessels technology, Vol. 123, No. 3, August, pp. 398-403.

Marston, A. (1930). The theory of external loads onclosed conduits in the loght of the latest experiments. Bulletin 96, Iowa Engineering experiment station, Ames, Iowa.

Marston, A., and Anderson, A.O. (1913). The theory of loads on pipes in ditches and tests of cement and clay drain tile and sewer pipe. Bulletin 31, Iowa Engineering experiment station, Ames, Iowa. 
McGrath, T.J., and Hoopes, R.J. (1998). Bedding factors and E' values for buried pipe installations backfilled with air-,modified CLSM. The design and Application of controlled low strength materials (Flowable Fill), ASTM STP 1331, A.K Howard and J.L. Hitch, Eds., American Society for Testing and Materials.

Moore, I.D. (1994). Local strain in corrugated pipe: Experimental measurements to test a numerical model. American Society of Testing and Evaluation.

Moore, I.D. (1995). Three-dimensional Response of Deeply Buried Profiled Polyethylene Pipe. Transportation Research Record, 1514, 49-58.

Moore, I.D., and Fuping, Hu. (1995). Response of profiled high-density polyethylene pipe in hoop compression. Transportation research record 1514, pp.29-36.

Moore, I.D., and Laidlaw, T.C. (1997). Corrugated buckling in HDPE pipes Measurements and analysis. Transportation Research Board, $76^{\text {th }}$ Annual Meeting, January 11-15, Washington, D.C.

Moore, I.D., and Selig, E.T. (1990). Use of continuum buckling theory for evaluation of buried plastic pipe stability. Technical publication 1093-Buried plastic pipe technology, ASTM, Philadelphia, pp. 334-359.

Moser, A.P. (1990). Buried pipe design. McGraw-Hill, Inc., NY.

Moser, A.P. (1998). Structural performance of buried profile-wall high-density polyethylene pipe and influence of pipe wall geometry. Transportation Research Record 1624, No. 98-0811, pp. 206-213.

Murray, N.W. (1975). Analysis and design of stiffened plates for collapse load. Structural Enginneer, Vol. 53, pp. 153-158.

Petroff, L.J. (1993). Ring bending stiffness and the design of flexible pipe. Proceedings of the second conference on structural performance of pipes, Sargand, G.F., Mitchell, G.F., \& Hurd, J.O (eds), March 14-17, Columbus, Ohio, pp.125-135.

Phares, B.M., Wipf, T.J., Klaiber, F.W., and Lohnes, R.A. (1998). Behavior of high-density polyethylene pipe with shallow cover. Transportation Research Record 1624, No. 980568, pp. 214-224.

PPI, Plastic pipe institute [Online]. (2005). Available: http://www.plasticpipe.org/pdf/pubs/designmanual/Chapter\%203.pdf, [6 August 2005].

Sargand, S.M., and Masada, T. (2000). Performance of large-diameter honeycomb-design HDPE pipe under a highway embarkment. Canadian Geochemical Journal, Vol. 37, pp. 1099-1108. 
Sargand, S.M., Masada, T., Tarawnwh, B., and Gruver, D. (2004). Field performance and analysis of large-diameter high-density polyethylene pipe under deep soil fill. Journal of geotechnical and geoenvironmental engineering, Vol. 131, No.1, pp. 39-51.

Selig, E.T., Leonard, C.D., and McGrath, T.J. (1994). Laboratory test of buried pipe in hoop compression. Buried plastic pipe technology, Vol. 2, pp. 119-132.

Simmons, A.R. (2002). Use of flowable fill as a backfill material around buried pipes. M.S.Thesis, Department of Civil and Environmental Engineering, west Virginia University.

Soleno, Inc., Technical manual: Characteristics of corrugated HDPE pipe [Online]. (2005). Available: http://soleno.com/an/corpo/entreprise.php, [6 August 2005].

Spangler, M.G. (1941). The structural design of flexible pipe culverts. Bulletin153, Iowa Engineering experiment station, Ames, Iowa.

Spangler, M.G. and Handy, R.L. (1982). Soil Engineering, 4th edition. Addison-Wesley Educational Publishers, Inc., Boston, MA.

Watkins, R. K., and Anderson, L.R. (1999). Structural mechanics of buried pipes. CRC press, NY.

Webb, M.C., McGrath, T.J., and Selig, E.T. (1998). Field test of buried pipe with CLSM backfill. The design and Application of controlled low strength materials (Flowable Fill), ASTM STP 1331, A.K Howard and J.L. Hitch, Eds., American Society for Testing and Materials.

West Virginia Division of Highways. (2000). Standard specifications: Roads and Bridges. Charleston, West Virginia.

Zhang, Chuntao., and Moore, I. D. (1997). Nonlinear mechanical response of high density polyethylene. Part I: Experimental investigation and model evaluation. Polymer engineering and science, February, Vol. 37, No.2, pp. 404-413.

Zhang, Chuntao., and Moore, I. D. (1997). Nonlinear mechanical response of high density polyethylene. Part II: Uniaxial constitutive modeling. Polymer engineering and science, February, Vol. 37, No.2, pp. 414-420.

Zhang, Chuntao., and Moore, I. D. (1997). Nonlinear finite element analysis for thermoplastic pipes. Transportation Research Record 1624, No. 98-0701, pp. 225-230.

Zienkewicz, O.C., and Taylor, R.L. (1991). The finite element method, Vols. 1 \& 2. McGraw-Hill Book Company, London. 


\section{Appendix A}

Numerical Data for 6-inch and 8-inch HDPE Pipes 
Table A.1: Pipe deflections under surcharge loading of the 6-inch pipe in cohesive insitu soil with low strength backfill

\begin{tabular}{|c|c|c|c|c|c|c|}
\hline \multirow{2}{*}{$\begin{array}{c}\text { Trench } \\
\text { width ratio } \\
\quad\left(\mathrm{n}_{\mathrm{r}}\right)\end{array}$} & \multicolumn{2}{|c|}{10 psi } & \multicolumn{2}{|c|}{20 psi } & \multicolumn{2}{|c|}{30 psi } \\
\hline & $\begin{array}{l}\text { Experimental } \\
\text { Results (inch) }\end{array}$ & $\begin{array}{c}\text { Numerical } \\
\text { Results (inch) }\end{array}$ & $\begin{array}{l}\text { Experimental } \\
\text { Results (inch) }\end{array}$ & $\begin{array}{c}\text { Numerical } \\
\text { Results (inch) }\end{array}$ & $\begin{array}{l}\text { Experimental } \\
\text { Results (inch) }\end{array}$ & $\begin{array}{c}\text { Numerical } \\
\text { Results (inch) }\end{array}$ \\
\hline 1.5 & 0.1017 & 0.0258 & 0.2259 & 0.0496 & 0.3244 & 0.073 \\
\hline 2 & 0.07 & 0.0022 & 0.1523 & 0.0425 & 0.2362 & 0.0628 \\
\hline 2.5 & 0.0473 & 0.02177 & 0.0967 & 0.04159 & 0.141 & 0.0614 \\
\hline
\end{tabular}

Table A.2: Pipe deflections under surcharge loading of the 6-inch pipe in cohesive insitu soil with high strength backfill

\begin{tabular}{|c|c|c|c|c|c|c|}
\hline \multirow{2}{*}{$\begin{array}{c}\text { Trench } \\
\text { width ratio } \\
\left(\mathrm{n}_{\mathrm{r}}\right)\end{array}$} & $\begin{array}{c}\text { 10 psi } \\
\text { Experimental } \\
\text { Results (inch) }\end{array}$ & $\begin{array}{c}\text { Numerical } \\
\text { Results (inch) }\end{array}$ & $\begin{array}{c}\text { Experimental } \\
\text { Results (inch) }\end{array}$ & $\begin{array}{c}\text { Numerical } \\
\text { Results (inch) }\end{array}$ & $\begin{array}{c}\text { Experimental } \\
\text { Results (inch) }\end{array}$ & $\begin{array}{c}\text { Numerical } \\
\text { Results (inch) }\end{array}$ \\
\hline $\mathbf{1 . 5}$ & 0.019 & 0.02 & 0.031 & 0.034 & -- & 0.081 \\
\hline $\mathbf{2}$ & 0.024 & 0.023 & 0.0299 & 0.0308 & -- & 0.059 \\
\hline $\mathbf{2 . 5}$ & 0.009 & 0.01 & 0.029 & 0.0293 & -- & 0.043 \\
\hline
\end{tabular}

Table A.3: Pipe deflections under surcharge loading of the 6-inch pipe in loose insitu soil with low strength backfill

\begin{tabular}{|c|c|c|c|c|c|c|}
\hline \multirow{2}{*}{$\begin{array}{c}\text { Trench } \\
\text { width ratio } \\
\left(\mathrm{n}_{\mathrm{r}}\right)\end{array}$} & $\begin{array}{c}\text { Experimental } \\
\text { Results (inch) }\end{array}$ & $\begin{array}{c}\text { Numerical } \\
\text { Results (inch) }\end{array}$ & $\begin{array}{c}\text { Experimental } \\
\text { Results (inch) }\end{array}$ & $\begin{array}{c}\text { Numerical } \\
\text { Results (inch) }\end{array}$ & $\begin{array}{c}\text { Experimental } \\
\text { Results (inch) }\end{array}$ & $\begin{array}{c}\text { Numerical } \\
\text { Results (inch) }\end{array}$ \\
\hline $\mathbf{1 . 5}$ & 0.239 & 0.0373 & 0.402 & 0.0701 & 0.512 & 0.1037 \\
\hline $\mathbf{2}$ & -- & 0.0321 & 0.2966 & 0.0614 & 0.4247 & 0.0908 \\
\hline $\mathbf{2 . 5}$ & 0.1647 & 0.0233 & 0.3354 & 0.0445 & 0.4908 & 0.0659 \\
\hline
\end{tabular}


Table A.4: Pipe deflections under surcharge loading of the 6-inch pipe in loose insitu soil with high strength backfill

\begin{tabular}{|c|c|c|c|c|c|c|}
\hline \multirow{2}{*}{$\begin{array}{c}\text { Trench } \\
\text { width ratio } \\
\left(\mathrm{n}_{\mathrm{r}}\right)\end{array}$} & \multicolumn{2}{|c|}{10 psi } & \multicolumn{2}{|c|}{20 psi } & \multicolumn{2}{|c|}{30 psi } \\
\hline & $\begin{array}{l}\text { Experimental } \\
\text { Results (inch) }\end{array}$ & $\begin{array}{c}\text { Numerical } \\
\text { Results (inch) }\end{array}$ & $\begin{array}{l}\text { Experimental } \\
\text { Results (inch) }\end{array}$ & $\begin{array}{c}\text { Numerical } \\
\text { Results (inch) }\end{array}$ & $\begin{array}{l}\text { Experimental } \\
\text { Results (inch) }\end{array}$ & $\begin{array}{c}\text { Numerical } \\
\text { Results (inch) }\end{array}$ \\
\hline 1.5 & 0.0245 & 0.028 & 0.0649 & 0.0647 & 0.102 & 0.11 \\
\hline 2 & 0.0194 & 0.021 & 0.039 & 0.0403 & 0.057 & 0.065 \\
\hline 2.5 & 0.0149 & 0.0161 & 0.052 & 0.049 & 0.049 & 0.047 \\
\hline
\end{tabular}

Table A.5: Pipe deflections under surcharge loading of the 8-inch pipe in cohesive insitu soil with low strength backfill

\begin{tabular}{|c|c|c|c|c|c|c|}
\hline \multirow{2}{*}{$\begin{array}{c}\text { Trench } \\
\text { width ratio } \\
\left(\mathrm{n}_{\mathrm{r}}\right)\end{array}$} & \multicolumn{2}{|c|}{$10 \mathrm{psi}$} & \multicolumn{2}{|c|}{$20 \mathrm{psi}$} & \multicolumn{2}{|c|}{$30 \mathrm{psi}$} \\
\hline & $\begin{array}{l}\text { Experimental } \\
\text { Results (inch) }\end{array}$ & $\begin{array}{c}\text { Numerical } \\
\text { Results (inch) }\end{array}$ & $\begin{array}{l}\text { Experimental } \\
\text { Results (inch) }\end{array}$ & $\begin{array}{l}\text { Numerical } \\
\text { Results (inch) }\end{array}$ & $\begin{array}{l}\text { Experimental } \\
\text { Results (inch) }\end{array}$ & $\begin{array}{l}\text { Numerical } \\
\text { Results (inch) }\end{array}$ \\
\hline 1.5 & 0.4229 & 0.04109 & 0.727 & 0.07899 & -- & 0.1169 \\
\hline 2 & 0.0747 & 0.0304 & 0.151 & 0.0584 & 0.2168 & 0.0864 \\
\hline 2.5 & 0.056 & 0.0292 & 0.131 & 0.0559 & 0.2275 & 0.0826 \\
\hline
\end{tabular}

Table A.6: Pipe deflections under surcharge loading of the 8-inch pipe in cohesive insitu soil with high strength backfill

\begin{tabular}{|c|c|c|c|c|c|c|}
\hline \multirow{2}{*}{$\begin{array}{c}\text { Trench } \\
\text { width ratio } \\
\left(\mathrm{n}_{\mathrm{r}}\right)\end{array}$} & $\begin{array}{c}\text { 10 psi } \\
\text { Experimental } \\
\text { Results (inch) }\end{array}$ & $\begin{array}{c}\text { Numerical } \\
\text { Results (inch) }\end{array}$ & $\begin{array}{c}\text { Experimental } \\
\text { Results (inch) }\end{array}$ & $\begin{array}{c}\text { Numerical } \\
\text { Results (inch) }\end{array}$ & $\begin{array}{c}\text { Experimental } \\
\text { Results (inch) }\end{array}$ & $\begin{array}{c}\text { Numerical } \\
\text { Results (inch) }\end{array}$ \\
\hline $\mathbf{1 . 5}$ & 0.054 & 0.05 & 0.127 & 0.115 & 0.16 & 0.139 \\
\hline $\mathbf{2}$ & 0.032 & 0.027 & 0.081 & 0.067 & 0.1 & 0.081 \\
\hline $\mathbf{2 . 5}$ & 0.0099 & 0.011 & 0.045 & 0.039 & 0.07 & 0.058 \\
\hline
\end{tabular}


Table A.7: Pipe deflections under surcharge loading of the 8-inch pipe in loose insitu soil with low strength backfill

\begin{tabular}{|c|c|c|c|c|c|c|}
\hline \multirow{2}{*}{$\begin{array}{c}\text { Trench } \\
\text { width ratio } \\
\left(\mathrm{n}_{\mathrm{r}}\right)\end{array}$} & $\begin{array}{c}\text { Experimental } \\
\text { Results (inch) }\end{array}$ & $\begin{array}{c}\text { Numerical } \\
\text { Results (inch) }\end{array}$ & $\begin{array}{c}\text { Experimental } \\
\text { Results (inch) }\end{array}$ & $\begin{array}{c}\text { Numerical } \\
\text { Results (inch) }\end{array}$ & $\begin{array}{c}\text { Experimental } \\
\text { Results (inch) }\end{array}$ & $\begin{array}{c}\text { Numerical } \\
\text { Results (inch) }\end{array}$ \\
\cline { 2 - 7 } $\mathbf{1 . 5}$ & 0.212 & 0.0517 & 0.416 & 0.0991 & 0.596 & 0.1471 \\
\hline $\mathbf{2}$ & 0.243 & 0.0358 & 0.455 & 0.0682 & 0.6294 & 0.1017 \\
\hline $\mathbf{2 . 5}$ & 0.0792 & 0.03 & 0.2561 & 0.0576 & 0.4085 & 0.0851 \\
\hline
\end{tabular}

Table A.8: Pipe deflections under surcharge loading of the 8-inch pipe in loose insitu soil with high strength backfill

\begin{tabular}{|c|c|c|c|c|c|c|}
\hline \multirow{2}{*}{$\begin{array}{c}\text { Trench } \\
\text { width ratio } \\
\left(\mathrm{n}_{\mathrm{r}}\right)\end{array}$} & $\begin{array}{c}\text { Experimental } \\
\text { Results (inch) }\end{array}$ & $\begin{array}{c}\text { Numerical } \\
\text { Results (inch) }\end{array}$ & $\begin{array}{c}\text { Experimental } \\
\text { Results (inch) }\end{array}$ & $\begin{array}{c}\text { Numerical } \\
\text { Results (inch) }\end{array}$ & $\begin{array}{c}\text { Experimental } \\
\text { Results (inch) }\end{array}$ & $\begin{array}{c}\text { Numerical } \\
\text { Results (inch) }\end{array}$ \\
\cline { 2 - 7 } $\mathbf{1 . 5}$ & 0.029 & 0.039 & 0.012 & 0.11 & 0.133 & 0.146 \\
\hline $\mathbf{2}$ & 0.035 & 0.0322 & 0.09 & 0.084 & 0.142 & 0.12 \\
\hline $\mathbf{2 . 5}$ & 0.021 & 0.018 & 0.067 & 0.074 & 0.1 & 0.089 \\
\hline
\end{tabular}

Table A.9: Stresses under surcharge loading of the 6-inch pipe in cohesive insitu soil with low strength backfill

\begin{tabular}{|c|c|c|c|c|c|c|}
\hline \multirow{2}{*}{$\begin{array}{c}\text { Trench } \\
\text { width ratio } \\
\left(\mathrm{n}_{\mathrm{r}}\right)\end{array}$} & $\begin{array}{c}\text { 10 psi } \\
\text { Experimental } \\
\text { Results (inch) }\end{array}$ & $\begin{array}{c}\text { Numerical } \\
\text { Results (inch) }\end{array}$ & $\begin{array}{c}\text { Experimental } \\
\text { Results (inch) }\end{array}$ & $\begin{array}{c}\text { Numerical } \\
\text { Results (inch) }\end{array}$ & $\begin{array}{c}\text { Experimental } \\
\text { Results (inch) }\end{array}$ & $\begin{array}{c}\text { Numerical } \\
\text { Results (inch) }\end{array}$ \\
\hline $\mathbf{1 . 5}$ & 14.6 & 12.2 & 21.78 & 21.09 & 28.36 & 31.17 \\
\hline $\mathbf{2}$ & 10.51 & 11.9 & 16.16 & 20.01 & 31.21 & 33.68 \\
\hline $\mathbf{2 . 5}$ & 17.28 & 12.88 & 31.87 & 31.44 & 40.94 & 36.9 \\
\hline
\end{tabular}


Table A.10: Stresses under surcharge loading of the 6-inch pipe in cohesive insitu soil with high strength backfill

\begin{tabular}{|c|c|c|c|c|c|c|}
\hline \multirow{2}{*}{$\begin{array}{c}\text { Trench } \\
\text { width ratio } \\
\left(\mathrm{n}_{\mathrm{r}}\right)\end{array}$} & $\begin{array}{c}\text { Experimental } \\
\text { Results (inch) }\end{array}$ & $\begin{array}{c}\text { Numerical } \\
\text { Results (inch) }\end{array}$ & $\begin{array}{c}\text { Experimental } \\
\text { Results (inch) }\end{array}$ & $\begin{array}{c}\text { 20 psi } \\
\text { Numerical } \\
\text { Results (inch) }\end{array}$ & $\begin{array}{c}\text { Experimental } \\
\text { Results (inch) }\end{array}$ & $\begin{array}{c}\text { Numerical } \\
\text { Results (inch) }\end{array}$ \\
\hline $\mathbf{1 . 5}$ & 17.39 & 14.93 & 33.12 & 28.5 & --- & 41.51 \\
\hline $\mathbf{2}$ & 13.15 & 12.37 & 24.73 & 23.57 & -- & 34.78 \\
\hline $\mathbf{2 . 5}$ & 9.6 & 8.69 & 20.87 & 22.47 & 28.72 & 28.12 \\
\hline
\end{tabular}

Table A.11: Stresses under surcharge loading of the 6-inch pipe in loose insitu soil with low strength backfill

\begin{tabular}{|c|c|c|c|c|c|c|}
\hline \multirow{2}{*}{$\begin{array}{c}\text { Trench } \\
\text { width ratio } \\
\left(\mathrm{n}_{\mathrm{r}}\right)\end{array}$} & $\begin{array}{c}\text { Experimental } \\
\text { Results (inch) }\end{array}$ & $\begin{array}{c}\text { Numerical } \\
\text { Results (inch) }\end{array}$ & $\begin{array}{c}\text { Experimental } \\
\text { Results (inch) }\end{array}$ & $\begin{array}{c}\text { Numerical } \\
\text { Results (inch) }\end{array}$ & $\begin{array}{c}\text { Experimental } \\
\text { Results (inch) }\end{array}$ & $\begin{array}{c}\text { Numerical } \\
\text { Results (inch) }\end{array}$ \\
\cline { 2 - 7 } $\mathbf{1 . 5}$ & 10.05 & 9.78 & 15.92 & 18.68 & 20.5 & 27.59 \\
\hline $\mathbf{2}$ & 11.65 & 11.03 & 18.29 & 21.07 & 24.78 & 31.11 \\
\hline $\mathbf{2 . 5}$ & 8.93 & 9.17 & 14.95 & 17.44 & 20.45 & 25.73 \\
\hline
\end{tabular}

Table A.12: Stresses under surcharge loading of the 8-inch pipe in cohesive insitu soil with low strength backfill

\begin{tabular}{|c|c|c|c|c|c|c|}
\hline \multirow{2}{*}{$\begin{array}{c}\text { Trench } \\
\text { width ratio } \\
\left(\mathrm{n}_{\mathrm{r}}\right)\end{array}$} & $\begin{array}{c}\text { 10 psi } \\
\text { Experimental } \\
\text { Results (inch) }\end{array}$ & $\begin{array}{c}\text { Numerical } \\
\text { Results (inch) }\end{array}$ & $\begin{array}{c}\text { Experimental } \\
\text { Results (inch) }\end{array}$ & $\begin{array}{c}\text { Numerical } \\
\text { Results (inch) }\end{array}$ & $\begin{array}{c}\text { Experimental } \\
\text { Results (inch) }\end{array}$ & $\begin{array}{c}\text { Numerical } \\
\text { Results (inch) }\end{array}$ \\
\hline $\mathbf{1 . 5}$ & 10.78 & 12.68 & 16.27 & 17.31 & -- & 25.56 \\
\hline $\mathbf{2}$ & 14.42 & 12.45 & 19.82 & 16.27 & 24.35 & 24.01 \\
\hline $\mathbf{2 . 5}$ & 10.12 & 11.6 & 15.98 & 16.27 & 20.89 & 23.01 \\
\hline
\end{tabular}


Table A.13: Stresses under surcharge loading of the 8-inch pipe in cohesive insitu soil with high strength backfill

\begin{tabular}{|c|c|c|c|c|c|c|}
\hline \multirow{2}{*}{$\begin{array}{c}\text { Trench } \\
\text { width ratio } \\
\left(\mathrm{n}_{\mathrm{r}}\right)\end{array}$} & $\begin{array}{c}\text { Experimental } \\
\text { Results (inch) }\end{array}$ & $\begin{array}{c}\text { Numerical } \\
\text { Results (inch) }\end{array}$ & $\begin{array}{c}\text { Experimental } \\
\text { Results (inch) }\end{array}$ & $\begin{array}{c}\text { Numerical } \\
\text { Results (inch) }\end{array}$ & $\begin{array}{c}\text { Experimental } \\
\text { Results (inch) }\end{array}$ & $\begin{array}{c}\text { Numerical } \\
\text { Results (inch) }\end{array}$ \\
\cline { 2 - 7 } & 1.5 & 14.67 & 23.79 & 28.05 & 29.4 & 29.30 \\
\hline $\mathbf{2}$ & 7.85 & 8.50 & 14.67 & 16.23 & 19.60 & 23.95 \\
\hline $\mathbf{2 . 5}$ & 4.54 & 7.17 & 8.55 & 13.68 & 10.61 & 11.05 \\
\hline
\end{tabular}

Table A.14: Stresses under surcharge loading of the 8-inch pipe in loose insitu soil with low strength backfill

\begin{tabular}{|c|c|c|c|c|c|c|}
\hline \multirow{2}{*}{$\begin{array}{c}\text { Trench } \\
\text { width ratio } \\
\left(\mathrm{n}_{\mathrm{r}}\right)\end{array}$} & $\begin{array}{c}\text { Experimental } \\
\text { Results (inch) }\end{array}$ & $\begin{array}{c}\text { Numerical } \\
\text { Results (inch) }\end{array}$ & $\begin{array}{c}\text { Experimental } \\
\text { Results (inch) }\end{array}$ & $\begin{array}{c}\text { Numerical } \\
\text { Results (inch) }\end{array}$ & $\begin{array}{c}\text { Experimental } \\
\text { Results (inch) }\end{array}$ & $\begin{array}{c}\text { Numerical } \\
\text { Results (inch) }\end{array}$ \\
\cline { 2 - 7 } & 10.2 & 10.158 & 16.29 & 17.65 & 21.71 & 20.105 \\
\hline $\mathbf{1 . 5}$ & 10.09 & 11.01 & 15.45 & 16.21 & 19.59 & 18.81 \\
\hline $\mathbf{2 . 5}$ & 7.73 & 9.23 & 13.26 & 14.18 & 17.26 & 16.177 \\
\hline
\end{tabular}

Table A.15: Pipe deflections under plate loading of the 6-inch pipe in cohesive insitu soil with low strength backfill

\begin{tabular}{|c|c|c|c|c|c|c|}
\hline \multirow{2}{*}{$\begin{array}{c}\text { Trench } \\
\text { width ratio } \\
\left(\mathrm{n}_{\mathrm{r}}\right)\end{array}$} & $\begin{array}{c}\text { Experimental } \\
\text { Results (inch) }\end{array}$ & $\begin{array}{c}\text { Numerical } \\
\text { Results (inch) }\end{array}$ & $\begin{array}{c}\text { Experimental } \\
\text { Results (inch) }\end{array}$ & $\begin{array}{c}\text { Numerical } \\
\text { Results (inch) }\end{array}$ & $\begin{array}{c}\text { Experimental } \\
\text { Results (inch) }\end{array}$ & $\begin{array}{c}\text { Numerical } \\
\text { Results (inch) }\end{array}$ \\
\cline { 3 - 7 } \\
$\mathbf{1 . 5}$
\end{tabular}


Table A.16: Pipe deflections under plate loading of the 6-inch pipe in cohesive insitu soil with high strength backfill

\begin{tabular}{|c|c|c|c|c|c|c|}
\hline \multirow{2}{*}{$\begin{array}{c}\text { Trench } \\
\text { width ratio } \\
\left(\mathrm{n}_{\mathrm{r}}\right)\end{array}$} & $\begin{array}{c}\text { Experimental } \\
\text { Results (inch) }\end{array}$ & $\begin{array}{c}\text { Numerical } \\
\text { Results (inch) }\end{array}$ & $\begin{array}{c}\text { Experimental } \\
\text { Results (inch) }\end{array}$ & $\begin{array}{c}\text { Numerical } \\
\text { Results (inch) }\end{array}$ & $\begin{array}{c}\text { Experimental } \\
\text { Results (inch) }\end{array}$ & $\begin{array}{c}\text { Numerical } \\
\text { Results (inch) }\end{array}$ \\
\hline $\mathbf{1 . 5}$ & & 0.00879 & & 0.01612 & 0.0195 \\
\hline $\mathbf{2}$ & & 0.00574 & & 0.00958 & & 0.01293 \\
\hline $\mathbf{2 . 5}$ & & 0.00328 & & 0.00529 & & 0.00729 \\
\hline
\end{tabular}

Table A.17: Pipe deflections under plate loading of the 6-inch pipe in loose insitu soil with low strength backfill

\begin{tabular}{|c|c|c|c|c|c|c|}
\hline \multirow{2}{*}{$\begin{array}{c}\text { Trench } \\
\text { width ratio } \\
\left(\mathrm{n}_{\mathrm{r}}\right)\end{array}$} & $\begin{array}{c}\text { Experimental } \\
\text { Results (inch) }\end{array}$ & $\begin{array}{c}\text { Numerical } \\
\text { Results (inch) }\end{array}$ & $\begin{array}{c}\text { Experimental } \\
\text { Results (inch) }\end{array}$ & $\begin{array}{c}\text { Numerical } \\
\text { Results (inch) }\end{array}$ & $\begin{array}{c}\text { Experimental } \\
\text { Results (inch) }\end{array}$ & $\begin{array}{c}\text { Numerical } \\
\text { Results (inch) }\end{array}$ \\
\hline $\mathbf{1 . 5}$ & & 0.0112 & & 0.0259 & & 0.027 \\
\hline $\mathbf{2}$ & & 0.00958 & & 0.01658 & & 0.01733 \\
\hline $\mathbf{2 . 5}$ & & 0.00537 & & 0.0086 & & 0.012 \\
\hline
\end{tabular}

Table A.18: Pipe deflections under plate loading of the 8-inch pipe in cohesive insitu soil with low strength backfill

\begin{tabular}{|c|c|c|c|c|c|c|}
\hline \multirow{2}{*}{$\begin{array}{c}\text { Trench } \\
\text { width ratio } \\
\left(\mathrm{n}_{\mathrm{r}}\right)\end{array}$} & $\begin{array}{c}\text { Experimental } \\
\text { Results (inch) }\end{array}$ & $\begin{array}{c}\text { Numerical } \\
\text { Results (inch) }\end{array}$ & $\begin{array}{c}\text { Experimental } \\
\text { Results (inch) }\end{array}$ & $\begin{array}{c}\text { Numerical } \\
\text { Results (inch) }\end{array}$ & $\begin{array}{c}\text { Experimental } \\
\text { Results (inch) }\end{array}$ & $\begin{array}{c}\text { Numerical } \\
\text { Results (inch) }\end{array}$ \\
\hline $\mathbf{1 . 5}$ & & 0.011 & & 0.0182 & 0.0252 \\
\hline $\mathbf{2}$ & & 0.0102 & & 0.0172 & & 0.0246 \\
\hline $\mathbf{2 . 5}$ & & 0.007 & & 0.0114 & & 0.0152 \\
\hline
\end{tabular}


Table A.19: Pipe deflections under plate loading of the 8-inch pipe in cohesive insitu soil with high strength backfill

\begin{tabular}{|c|c|c|c|c|c|c|}
\hline \multirow{2}{*}{$\begin{array}{c}\text { Trench } \\
\text { width ratio } \\
\left(\mathrm{n}_{\mathrm{r}}\right)\end{array}$} & $\begin{array}{c}\text { Experimental } \\
\text { Results (inch) }\end{array}$ & $\begin{array}{c}\text { Numerical } \\
\text { Results (inch) }\end{array}$ & $\begin{array}{c}\text { Experimental } \\
\text { Results (inch) }\end{array}$ & $\begin{array}{c}\text { Numerical } \\
\text { Results (inch) }\end{array}$ & $\begin{array}{c}\text { Experimental } \\
\text { Results (inch) }\end{array}$ & $\begin{array}{c}\text { Numerical } \\
\text { Results (inch) }\end{array}$ \\
\hline $\mathbf{1 . 5}$ & & 0.0126 & & 0.01709 & 0.032 \\
\hline $\mathbf{2}$ & & 0.00854 & & 0.015 & & 0.02119 \\
\hline $\mathbf{2 . 5}$ & & 0.00457 & & 0.0062 & & 0.0085 \\
\hline
\end{tabular}

Table A.20: Pipe deflections under plate loading of the 8-inch pipe in loose insitu soil with low strength backfill

\begin{tabular}{|c|c|c|c|c|c|c|}
\hline \multirow{2}{*}{$\begin{array}{c}\text { Trench } \\
\text { width ratio } \\
\left(\mathrm{n}_{\mathrm{r}}\right)\end{array}$} & $\begin{array}{c}\text { Experimental } \\
\text { Results (inch) }\end{array}$ & $\begin{array}{c}\text { Numerical } \\
\text { Results (inch) }\end{array}$ & $\begin{array}{c}\text { Experimental } \\
\text { Results (inch) }\end{array}$ & $\begin{array}{c}\text { Numerical } \\
\text { Results (inch) }\end{array}$ & $\begin{array}{c}\text { Experimental } \\
\text { Results (inch) }\end{array}$ & $\begin{array}{c}\text { Numerical } \\
\text { Results (inch) }\end{array}$ \\
\hline $\mathbf{1 . 5}$ & & 0.0142 & & 0.0276 & & 0.0327 \\
\hline $\mathbf{2}$ & & 0.01242 & & 0.0214 & & 0.0304 \\
\hline $\mathbf{2 . 5}$ & & 0.00729 & & 0.0119 & & 0.01617 \\
\hline
\end{tabular}

Table A.21: Stresses under plate loading of the 6-inch pipe in cohesive insitu soil with low strength backfill

\begin{tabular}{|c|c|c|c|c|c|c|}
\hline \multirow{2}{*}{$\begin{array}{c}\text { Trench } \\
\text { width ratio } \\
\left(\mathrm{n}_{\mathrm{r}}\right)\end{array}$} & $\begin{array}{c}\text { Experimental } \\
\text { Results (inch) }\end{array}$ & $\begin{array}{c}\text { Numerical } \\
\text { Results (inch) }\end{array}$ & $\begin{array}{c}\text { Experimental } \\
\text { Results (inch) }\end{array}$ & $\begin{array}{c}\text { Numerical } \\
\text { Results (inch) }\end{array}$ & $\begin{array}{c}\text { Experimental } \\
\text { Results (inch) }\end{array}$ & $\begin{array}{c}\text { Numerical } \\
\text { Results (inch) }\end{array}$ \\
\cline { 2 - 7 } $\mathbf{1 . 5}$ & 8.15 & 9.86 & 10.95 & 10.007 & 14.46 & 13.76 \\
\hline $\mathbf{2}$ & 7.14 & 7.97 & 9.05 & 12.83 & 11.44 & 14.30 \\
\hline $\mathbf{2 . 5}$ & 12.46 & 12.98 & 16.03 & 16.49 & 19.29 & 18.01 \\
\hline
\end{tabular}


Table A.22: Stresses under plate loading of the 6-inch pipe in cohesive insitu soil with high strength backfill

\begin{tabular}{|c|c|c|c|c|c|c|}
\hline \multirow{2}{*}{$\begin{array}{c}\text { Trench } \\
\text { width ratio } \\
\left(\mathrm{n}_{\mathrm{r}}\right)\end{array}$} & $\begin{array}{c}\text { Experimental } \\
\text { Results (inch) }\end{array}$ & $\begin{array}{c}\text { Numerical } \\
\text { Results (inch) }\end{array}$ & $\begin{array}{c}\text { Experimental } \\
\text { Results (inch) }\end{array}$ & $\begin{array}{c}\text { 2000 lb } \\
\text { Numerical } \\
\text { Results (inch) }\end{array}$ & $\begin{array}{c}\text { Experimental } \\
\text { Results (inch) }\end{array}$ & $\begin{array}{c}\text { Numerical } \\
\text { Results (inch) }\end{array}$ \\
\hline $\mathbf{1 . 5}$ & 8.63 & 10.17 & 17.45 & 16.36 & 27.05 & 24.06 \\
\hline $\mathbf{2}$ & 3.86 & 6.16 & 6.33 & 8.47 & 10.69 & 20.053 \\
\hline $\mathbf{2 . 5}$ & -- & 3.84 & 15.24 & 6.35 & 19.04 & 18.98 \\
\hline
\end{tabular}

Table A.23: Stresses under plate loading of the 6-inch pipe in loose insitu soil with low strength backfill

\begin{tabular}{|c|c|c|c|c|c|c|}
\hline \multirow{2}{*}{$\begin{array}{c}\text { Trench } \\
\text { width ratio } \\
\left(\mathrm{n}_{\mathrm{r}}\right)\end{array}$} & $\begin{array}{c}\text { Experimental } \\
\text { Results (inch) }\end{array}$ & $\begin{array}{c}\text { Numerical } \\
\text { Results (inch) }\end{array}$ & $\begin{array}{c}\text { Experimental } \\
\text { Results (inch) }\end{array}$ & $\begin{array}{c}\text { Numerical } \\
\text { Results (inch) }\end{array}$ & $\begin{array}{c}\text { Experimental } \\
\text { Results (inch) }\end{array}$ & $\begin{array}{c}\text { Numerical } \\
\text { Results (inch) }\end{array}$ \\
\cline { 2 - 7 } $\mathbf{1 . 5}$ & 6.46 & 6.62 & 8.45 & 8.48 & 11.96 & 12.01 \\
\hline $\mathbf{2}$ & 4.78 & 5.01 & 7.6 & 7.39 & 9.49 & 10.01 \\
\hline $\mathbf{2 . 5}$ & 4.17 & 4.09 & 5.6 & 6.29 & 6.96 & 7.33 \\
\hline
\end{tabular}

Table A.24: Stresses under plate loading of the 8-inch pipe in cohesive insitu soil with low strength backfill

\begin{tabular}{|c|c|c|c|c|c|c|}
\hline \multirow{2}{*}{$\begin{array}{c}\text { Trench } \\
\text { width ratio } \\
\left(\mathrm{n}_{\mathrm{r}}\right)\end{array}$} & \multicolumn{2}{|c|}{$1000 \mathrm{lb}$} & \multicolumn{2}{|c|}{$2000 \mathrm{lb}$} & \multicolumn{2}{|c|}{$3000 \mathrm{lb}$} \\
\hline & $\begin{array}{l}\text { Experimental } \\
\text { Results (inch) }\end{array}$ & $\begin{array}{c}\text { Numerical } \\
\text { Results (inch) }\end{array}$ & $\begin{array}{l}\text { Experimental } \\
\text { Results (inch) }\end{array}$ & $\begin{array}{c}\text { Numerical } \\
\text { Results (inch) }\end{array}$ & $\begin{array}{l}\text { Experimental } \\
\text { Results (inch) }\end{array}$ & $\begin{array}{c}\text { Numerical } \\
\text { Results (inch) }\end{array}$ \\
\hline 1.5 & 5.57 & 7.59 & 6.53 & 6.404 & 14.46 & 19.86 \\
\hline 2 & 8.99 & 9.58 & 10.15 & 8.744 & 11.44 & 17.78 \\
\hline 2.5 & 7.19 & 8.69 & 8.97 & 10.52 & 19.29 & 21.502 \\
\hline
\end{tabular}


Table A.25: Stresses under plate loading of the 8-inch pipe in cohesive insitu soil with high strength backfill

\begin{tabular}{|c|c|c|c|c|c|c|}
\hline \multirow{2}{*}{$\begin{array}{c}\text { Trench } \\
\text { width ratio } \\
\left(\mathrm{n}_{\mathrm{r}}\right)\end{array}$} & $\begin{array}{c}\text { Experimental } \\
\text { Results (inch) }\end{array}$ & $\begin{array}{c}\text { Numerical } \\
\text { Results (inch) }\end{array}$ & $\begin{array}{c}\text { Experimental } \\
\text { Results (inch) }\end{array}$ & $\begin{array}{c}\text { Numerical } \\
\text { Results (inch) }\end{array}$ & $\begin{array}{c}\text { Experimental } \\
\text { Results (inch) }\end{array}$ & $\begin{array}{c}\text { Numerical } \\
\text { Results (inch) }\end{array}$ \\
\cline { 2 - 7 } $\mathbf{1 . 5}$ & 8.94 & 8.903 & 11.67 & 10.505 & 13.53 & 13.77 \\
\hline $\mathbf{2}$ & 6.53 & 6.42 & 8.32 & 8.18 & 10.83 & 10.92 \\
\hline $\mathbf{2 . 5}$ & 4.13 & 4.09 & 6.13 & 5.99 & 8.25 & 8.91 \\
\hline
\end{tabular}

Table A.26: Stresses under plate loading of the 8-inch pipe in loose insitu soil with low strength backfill

\begin{tabular}{|c|c|c|c|c|c|c|}
\hline \multirow{2}{*}{$\begin{array}{c}\text { Trench } \\
\text { width ratio } \\
\left(\mathrm{n}_{\mathrm{r}}\right)\end{array}$} & $\begin{array}{c}\text { Experimental } \\
\text { Results (inch) }\end{array}$ & $\begin{array}{c}\text { Numerical } \\
\text { Results (inch) }\end{array}$ & $\begin{array}{c}\text { Experimental } \\
\text { Results (inch) }\end{array}$ & $\begin{array}{c}\text { Numerical } \\
\text { Results (inch) }\end{array}$ & $\begin{array}{c}\text { Experimental } \\
\text { Results (inch) }\end{array}$ & $\begin{array}{c}\text { Numerical } \\
\text { Results (inch) }\end{array}$ \\
\cline { 2 - 7 } $\mathbf{1 . 5}$ & 3.79 & 3.17 & 5.15 & 4.784 & 6.82 & 5.89 \\
\hline $\mathbf{2}$ & 5.3 & 4.39 & 6.41 & 4.51 & 6.83 & 5.39 \\
\hline $\mathbf{2 . 5}$ & 2.91 & 2.34 & 3.62 & 4.13 & 3.87 & 3.53 \\
\hline
\end{tabular}




\section{Appendix B}

Numerical Data for 18-inch and 24-inch HDPE Pipes 
Table B.1: Variation of vertical pipe deflection with time for the 18 -inch pipe at 20 feet depth

\begin{tabular}{|c|c|c|c|}
\hline \multirow{2}{*}{$\begin{array}{c}\text { Trench width } \\
\text { ratio }\left(\mathrm{n}_{\mathrm{r}}\right)\end{array}$} & Pipe Deflection (inches) \\
\cline { 2 - 4 } & Time = 0 years & Time = 5 years & Time = 50 years \\
\hline $\mathbf{1 . 5}$ & 0.212 & 0.268 & 0.5499 \\
\hline $\mathbf{2}$ & 0.2072 & 0.2371 & 0.3659 \\
\hline $\mathbf{2 . 5}$ & 0.1457 & 0.1826 & 0.3573 \\
\hline
\end{tabular}

Table B.2: Variation of vertical pipe deflection with time for the 24 -inch pipe at 20 feet depth

\begin{tabular}{|c|c|c|c|}
\hline \multirow{2}{*}{$\begin{array}{c}\text { Trench width } \\
\text { ratio }\left(\mathrm{n}_{\mathrm{r}}\right)\end{array}$} & Pipe Deflection (inches) \\
\cline { 2 - 4 } & Time = 0 years & Time $=\mathbf{5}$ years & Time $=\mathbf{5 0}$ years \\
\hline $\mathbf{1 . 5}$ & 0.2591 & 0.3261 & 0.6436 \\
\hline $\mathbf{2}$ & 0.231 & 0.290 & 0.5699 \\
\hline $\mathbf{2 . 5}$ & 0.2117 & 0.2654 & 0.5234 \\
\hline
\end{tabular}

Table B.3: Variation of pipe deflection with depth for the 18-inch HDPE pipe

\begin{tabular}{|c|c|c|c|c|}
\hline Depth (ft) & $\begin{array}{c}\text { \% Deflection } \\
\text { Without Interface at } \\
\mathbf{t}=\mathbf{0} \text { Years }\end{array}$ & $\begin{array}{c}\text { \% Deflection } \\
\text { Without Interface at } \\
\mathbf{T}=\mathbf{5 0} \text { Years }\end{array}$ & $\begin{array}{c}\text { \% Deflection } \\
\text { With Interface at } \\
\mathbf{t}=\mathbf{0} \text { Years }\end{array}$ & $\begin{array}{c}\text { \% Deflection } \\
\text { With Interface at } \\
\mathbf{t}=\mathbf{5 0} \text { Years }\end{array}$ \\
\hline 20 Feet & 1.03 & 1.66 & 1.134 & 1.82 \\
\hline 30 Feet & 1.36 & 2.14 & 1.44 & 2.34 \\
\hline 40 Feet & 1.7 & 2.68 & 1.8 & 2.92 \\
\hline 50 Feet & 2.03 & 3.22 & 2.2 & 3.5 \\
\hline 60 Feet & 2.41 & 3.75 & 2.55 & 4.08 \\
\hline
\end{tabular}


Table B.4: Variation of pipe deflection with depth for the 24-inch HDPE pipe

\begin{tabular}{|c|c|c|c|c|}
\hline Depth (ft) & $\begin{array}{c}\text { \% Deflection } \\
\text { Without Interface at } \\
\mathbf{t}=\mathbf{0} \text { Years }\end{array}$ & $\begin{array}{c}\text { \% Deflection } \\
\text { Without Interface at } \\
\mathbf{t}=\mathbf{5 0} \text { Years }\end{array}$ & $\begin{array}{c}\text { \% Deflection } \\
\text { With Interface at } \\
\mathbf{t}=\mathbf{0} \text { Years }\end{array}$ & $\begin{array}{c}\text { \% Deflection } \\
\text { With Interface at } \\
\mathbf{t}=\mathbf{5 0} \text { Years }\end{array}$ \\
\hline 20 Feet & 1.15 & 1.767 & 1.275 & 2.01 \\
\hline 30 Feet & 1.437 & 2.216 & 1.55 & 2.45 \\
\hline 40 Feet & 1.77 & 2.72 & 1.9 & 3.56 \\
\hline 50 Feet & 2.1 & 3.236 & 2.25 & 4.125 \\
\hline 60 Feet & 2.43 & 3.75 & 2.6 & \\
\hline
\end{tabular}

Table B.5: Variation of deflection with depth of the 18-inch HDPE pipe with interface for a trench width ratio, $\left(\mathrm{N}_{\mathrm{r}}\right)=1.5,2,2.5$ and 3

\begin{tabular}{|c|c|c|c|c|c|c|c|c|}
\hline \multirow{2}{*}{ Depth (ft) } & \multicolumn{2}{|c|}{$\begin{array}{c}\text { Trench width ratio, } \\
\qquad \mathbf{n}_{\mathrm{r}}=1.5\end{array}$} & \multicolumn{2}{|c|}{$\begin{array}{c}\text { Trench width ratio, } \\
\qquad \mathbf{n}_{\mathrm{r}}=\mathbf{2}\end{array}$} & \multicolumn{2}{|c|}{$\begin{array}{c}\text { Trench width ratio, } \\
\qquad \mathrm{n}_{\mathrm{r}}=\mathbf{2 . 5}\end{array}$} & \multicolumn{2}{|c|}{$\begin{array}{c}\text { Trench width ratio, } \\
\qquad \mathbf{n}_{\mathrm{r}}=\mathbf{3}\end{array}$} \\
\hline & $\begin{array}{c}t=0 \\
\text { years }\end{array}$ & $\begin{array}{l}t=50 \\
\text { years }\end{array}$ & $\begin{array}{c}t=0 \\
\text { years }\end{array}$ & $\begin{array}{l}t=50 \\
\text { years }\end{array}$ & $\begin{array}{c}t=0 \\
\text { years }\end{array}$ & $\begin{array}{l}t=50 \\
\text { years }\end{array}$ & $\begin{array}{c}t=0 \\
\text { years }\end{array}$ & $\begin{array}{l}t=50 \\
\text { years }\end{array}$ \\
\hline 20 Feet & 2.255 & 3.878 & 1.988 & 3.244 & 1.744 & 2.788 & 1.555 & 2.483 \\
\hline 40 Feet & 2.638 & 4.527 & 2.411 & 3.938 & 2.183 & 3.5 & 2.005 & 3.194 \\
\hline 60 Feet & 3.016 & 5.194 & 2.838 & 4.627 & 2.627 & 4.211 & 2.455 & 3.911 \\
\hline
\end{tabular}


Table B.6: Variation of deflection with depth of the 18-inch HDPE pipe with interface for a trench width ratio, $\left(\mathrm{N}_{\mathrm{r}}\right)=1.5,2,2.5$ and 3

\begin{tabular}{|c|c|c|c|c|c|c|c|c|}
\hline \multirow{2}{*}{ Depth (ft) } & \multicolumn{2}{|c|}{$\begin{array}{c}\text { Trench width ratio, } \\
\mathrm{n}_{\mathrm{r}}=1.5\end{array}$} & \multicolumn{2}{|c|}{$\begin{array}{c}\text { Trench width ratio, } \\
\qquad \mathbf{n}_{\mathrm{r}}=\mathbf{2}\end{array}$} & \multicolumn{2}{|c|}{$\begin{array}{c}\text { Trench width ratio, } \\
\mathrm{n}_{\mathrm{r}}=2.5\end{array}$} & \multicolumn{2}{|c|}{$\begin{array}{c}\text { Trench width ratio, } \\
\qquad \mathbf{n}_{\mathbf{r}}=\mathbf{3}\end{array}$} \\
\hline & $\begin{array}{c}t=0 \\
\text { years }\end{array}$ & $\begin{array}{l}t=50 \\
\text { years }\end{array}$ & $\begin{array}{c}t=0 \\
\text { years }\end{array}$ & $\begin{array}{l}t=50 \\
\text { years }\end{array}$ & $\begin{array}{c}t=0 \\
\text { years }\end{array}$ & $\begin{array}{l}t=50 \\
\text { years }\end{array}$ & $\begin{array}{c}t=0 \\
\text { years }\end{array}$ & $\begin{array}{l}t=50 \\
\text { years }\end{array}$ \\
\hline 20 Feet & 1.8 & 3.008 & 1.612 & 2.526 & 1.437 & 2.242 & 1.296 & 2.008 \\
\hline 40 Feet & 2.183 & 3.65 & 2.042 & 3.241 & 1.887 & 2.941 & 1.754 & 2.716 \\
\hline 60 Feet & 2.566 & 4.291 & 2.47 & 3.925 & 2.333 & 3.641 & 2.216 & 3.425 \\
\hline
\end{tabular}




\section{Appendix C}

\section{Back Calculation of CLSM Stiffness Properties}




\section{C.1 Back calculation of CLSM stiffness properties}

The ring deflection of buried flexible circular pipes can be predicted by using the modified Iowa formula (Spangler, 1941). This formula is popular in predicting the deflection of flexible pipes. The pipe deflection can be expressed as:

$\Delta y=\frac{D_{f} K_{s} W_{c} r^{3}}{E I+0.061 E^{\prime} r^{3}}$

Where,

$\Delta y=$ Vertical deflection

$\mathrm{K}_{\mathrm{s}}=$ Bedding constant (generally $=0.1$ )

$\mathrm{D}_{\mathrm{f}}=$ Deflection lag factor (1.0 when prism load is used)

$\mathrm{W}_{\mathrm{c}}=$ Marston load per unit length $\left(\mathrm{W}_{\mathrm{c}} \approx \mathrm{PD}\right)$

$\mathrm{P}_{\mathrm{L}}=$ Vertical pressure due to live load

$\mathrm{P}_{\mathrm{d}}=$ Vertical pressure due to dead load $\left(\mathrm{P}_{\mathrm{d}}=\gamma \mathrm{H}\right)$

$\mathrm{P}=$ Vertical soil pressure on top of the pipe $\left(\mathrm{P}=\mathrm{P}_{\mathrm{d}}+\mathrm{P}_{\mathrm{L}}\right)$

$\mathrm{H}=$ Height of the soil cover

$\mathrm{D}=$ Mean circular diameter of the pipe

$r=$ Mean radius of the pipe $(D / 2)$

$\mathrm{EI}=$ Stiffness of the pipe per unit length

$\mathrm{E}^{\prime}=$ Modulus of soil reaction

Equation C.1 was used to back calculate the Young's modulus (E') of the CLSM above the pipe for a given vertical deflection $(\Delta y)$. The vertical deflections $(\Delta y)$ obtained from the experimental data were used to find an approximate value for the Young's modulus ( $\left.\mathrm{E}^{\prime}\right)$ of the CLSM above the pipe.

Calculation procedure for back calculating the value of $\mathrm{E}^{\prime}$ is given below. In the example given below, an 8-inch diameter pipe buried at a depth of 8-inch $(\mathrm{H}=8 \mathrm{in})$ with a surcharge load of 20 psi acting at the ground surface was considered as shown in Figure C.1. 


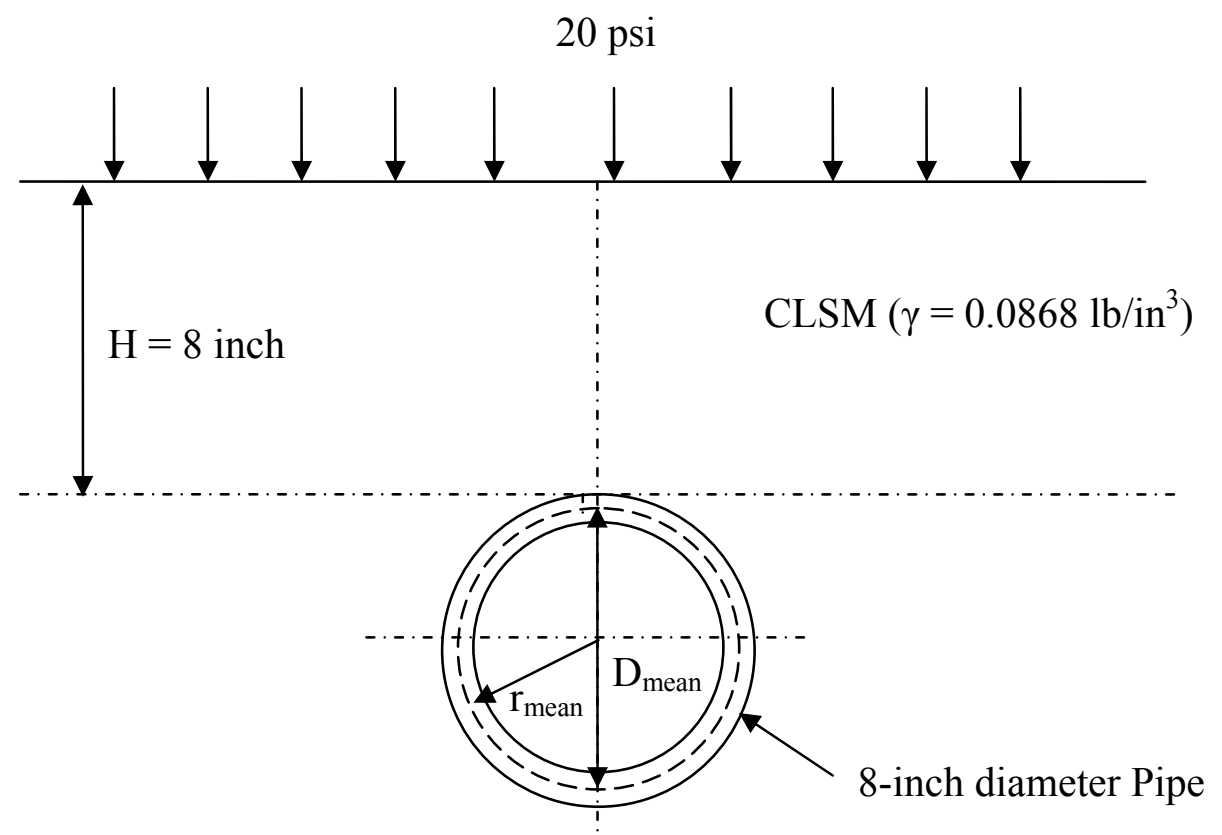

Figure C.1: 8-inch diameter pipe buried at a depth $(\mathrm{H}=8)$ with a surface load of 20 psi acting at the ground surface

The pipe stiffness can be expressed as (Moser, 1990):

$$
\mathrm{K}=6.7 \mathrm{EI} / \mathrm{r}^{3}
$$

Equation C. 2 can be written as:

$$
E I=\frac{K r^{3}}{6.7}
$$

Where,

$\mathrm{E}=$ modulus of elasticity of pipe material

$\mathrm{r}=$ mean pipe radius (Given in Table 3.10)

$\mathrm{I}=$ Moment of inertia (Given in Table 3.10)

$\mathrm{K}=$ pipe stiffness (Given in Table 3.10) 
Properties of a 8-inch HDPE pipe is given below (See Table 3.10)

Pipe stiffness $(\mathrm{K})=35 \mathrm{psi}$

$\mathrm{D}_{\text {mean }}=\mathrm{D}_{\text {int }}+2 \mathrm{C}=8.776$ in

$\mathrm{r}_{\text {mean }}=4.388$ in

Substituting these values in Equation C.3, the stiffness of the pipe (EI) can be calculated as:

\section{$E I=441.3 \mathrm{lb}-\mathrm{in}$}

Vertical pressure due to dead load can be expressed as:

$$
\left(\mathrm{P}_{\mathrm{d}}\right)=\gamma \mathrm{H}
$$

Where,

$\gamma=$ Soil density $\left(0.0868 \mathrm{lb} / \mathrm{in}^{3}=150 \mathrm{pcf}\right)$

$\mathrm{H}=$ Height of the soil cover $(8 \mathrm{in})$

Substituting these values in Equation C.4,

$$
\begin{aligned}
& P_{d}=0.6944 \mathrm{lb} / \mathrm{in}^{2} \\
& P_{L}=\text { vertical pressure due to live load }=20 \mathrm{lb} / \mathrm{in}^{2} \\
& \mathrm{P}=\mathrm{P}_{\mathrm{d}}+\mathrm{P}_{\mathrm{L}}=20.6944 \mathrm{lb} / \mathrm{in}^{2}
\end{aligned}
$$

Marston load per unit length can be expressed as:

$$
\mathrm{W}_{\mathrm{c}} \approx \mathrm{PD}
$$

Where,

$\mathrm{P}=$ Vertical soil pressure on top of the pipe $\left(\mathrm{P}=20.6944 \mathrm{lb} / \mathrm{in}^{2}\right)$

$\mathrm{D}=$ Mean circular diameter of the pipe (8.776 in)

Substituting these values in Equation C.5, the value of $\mathrm{W}_{\mathrm{c}}$ can be calculated as:

$$
\mathrm{W}_{\mathrm{c}}=181.614 \mathrm{lbs} / \mathrm{in} \text {. }
$$

By substituting the above values in Equation C.1 for a vertical deflection of 0.151 inches (measured value), the following equation can be derived. 
$0.151=\frac{0.1 \times 1 \times 181 \times(4.388)^{3}}{441.3+5.15 \mathrm{E}^{\prime}}$

The value of $E^{\prime}$ can be calculated as:

$$
\mathrm{E}^{\prime}=1880.8 \mathrm{psi} \approx 1881 \mathrm{psi}
$$

The following tables show the measured deflection values under laboratory conditions and the Young's modulus (E') for different CLSM mixtures that were back calculated by using the above procedure: 
Table C.1: Measured deflection values for low strength CLSM mixtures at trench width ratio of $1.5\left(\mathrm{~N}_{\mathrm{r}}=1.5\right)$ [See Figure 5.1 and 5.3 (Simmons, 2002)].

\begin{tabular}{|c|c|c|c|c|c|c|}
\hline \multirow{2}{*}{ CLSM mixtures } & \multicolumn{3}{|c|}{$\begin{array}{c}\text { Deflections for } 6 \text { inch HDPE } \\
\text { pipe (in) under surcharge loading }\end{array}$} & \multicolumn{3}{c|}{$\begin{array}{c}\text { Deflections for 8 inch HDPE } \\
\text { pipe (in) under surcharge loading }\end{array}$} \\
\cline { 2 - 7 } & $10 \mathrm{psi}$ & $20 \mathrm{psi}$ & $30 \mathrm{psi}$ & $10 \mathrm{psi}$ & $20 \mathrm{psi}$ & $30 \mathrm{psi}$ \\
\hline $\begin{array}{c}\text { Low strength } \\
\text { CLSM mixture 1 }\end{array}$ & 0.1 & 0.226 & 0.324 & 0.43 & 0.727 & -- \\
\hline $\begin{array}{c}\text { Low strength } \\
\text { CLSM mixture 2 }\end{array}$ & 0.24 & 0.4 & 0.51 & 0.2 & 0.4 & 0.6 \\
\hline
\end{tabular}

Table C.2: Calculated (E') values for low strength CLSM mixtures at trench width ratio of $1.5\left(\mathrm{~N}_{\mathrm{r}}=1.5\right)$

\begin{tabular}{|c|c|c|c|c|c|c|}
\hline \multirow{2}{*}{ CLSM mixtures } & \multicolumn{3}{|c|}{$\begin{array}{c}\text { Calculated (E') 6 inch HDPE } \\
\text { pipe (psi) under surcharge loading }\end{array}$} & \multicolumn{3}{c|}{$\begin{array}{c}\text { Calculated }\left(E^{\prime}\right) 8 \text { inch HDPE } \\
\text { pipe (psi) under surcharge loading }\end{array}$} \\
\cline { 2 - 7 } & $10 \mathrm{psi}$ & $20 \mathrm{psi}$ & $30 \mathrm{psi}$ & $10 \mathrm{psi}$ & $20 \mathrm{psi}$ & $30 \mathrm{psi}$ \\
\hline $\begin{array}{c}\text { Low strength } \\
\text { CLSM mixture 1 }\end{array}$ & 1012.9 & 889.42 & 920.43 & 272.38 & 322.7 & -- \\
\hline $\begin{array}{c}\text { Low strength } \\
\text { CLSM mixture 2 }\end{array}$ & 372.08 & 465.26 & 553.508 & 684.17 & 656.6 & 650.85 \\
\hline
\end{tabular}

From Table C.2,

Minimum $\left(E^{\prime}\right)=272.38$ psi

$\operatorname{Maximum}\left(E^{\prime}\right)=1012.9 \mathrm{psi}$

Average $\left(\mathrm{E}^{\prime}\right)=618.2 \mathrm{psi}$

Value used in FE analysis $\left(\mathrm{E}^{\prime}\right)=400 \mathrm{psi}$

When the average value of $E^{\prime}$ was used in the finite element analysis, the comparison between experimental and numerical values was not satisfactory. Therefore, a trail and error method was used to determine the Young's modulus ( $\left.E^{\prime}\right)$ for low strength CLSM mixtures with trench width ratio of $1.5\left(\mathrm{~N}_{\mathrm{r}}=1.5\right)$. The finite element results were in good agreement with the laboratory experimental results when $\mathrm{E}^{\prime}$ was assumed as 400 psi. This value falls between the maximum and minimum values shown above. 
Table C.3: Measured deflection values for low strength CLSM mixtures at trench width ratio of $2\left(\mathrm{~N}_{\mathrm{r}}=2\right)$ [See Figure 5.1 and 5.3 (Simmons, 2002)].

\begin{tabular}{|c|c|c|c|c|c|c|}
\hline \multirow[t]{2}{*}{ CLSM mixtures } & \multicolumn{3}{|c|}{$\begin{array}{c}\text { Deflections for } 6 \text { inch HDPE } \\
\text { pipe (in) under surcharge loading }\end{array}$} & \multicolumn{3}{|c|}{$\begin{array}{c}\text { Deflections for } 8 \text { inch HDPE } \\
\text { pipe (in) under surcharge loading }\end{array}$} \\
\hline & $10 \mathrm{psi}$ & $20 \mathrm{psi}$ & $30 \mathrm{psi}$ & $10 \mathrm{psi}$ & 20 psi & $30 \mathrm{psi}$ \\
\hline $\begin{array}{c}\text { Low strength } \\
\text { CLSM mixture } 1\end{array}$ & 0.07 & 0.1523 & 0.2362 & 0.0747 & 0.151 & 0.2168 \\
\hline $\begin{array}{c}\text { Low strength } \\
\text { CLSM mixture } 2\end{array}$ & -- & 0.296 & 0.4247 & 0.243 & 0.435 & 0.6294 \\
\hline
\end{tabular}

Table C.4: Calculated ( $\left.\mathrm{E}^{\prime}\right)$ values for low strength CLSM mixtures at trench width ratio of $2\left(\mathrm{~N}_{\mathrm{r}}=2\right)$

\begin{tabular}{|c|c|c|c|c|c|c|}
\hline \multirow{2}{*}{ CLSM mixtures } & \multicolumn{3}{|c|}{$\begin{array}{c}\text { Calculated (E') 6 inch HDPE } \\
\text { pipe (psi) under surcharge loading }\end{array}$} & \multicolumn{3}{c|}{$\begin{array}{c}\text { Calculated }\left(E^{\prime}\right) 8 \text { inch HDPE } \\
\text { pipsi) under surcharge loading }\end{array}$} \\
\cline { 2 - 7 } & $10 \mathrm{psi}$ & $20 \mathrm{psi}$ & $30 \mathrm{psi}$ & $10 \mathrm{psi}$ & $20 \mathrm{psi}$ & $30 \mathrm{psi}$ \\
\hline $\begin{array}{c}\text { Low strength } \\
\text { CLSM mixture 1 }\end{array}$ & 1553.9 & 1361.27 & 1294.42 & 1975.52 & 1880.8 & 1952.7 \\
\hline $\begin{array}{c}\text { Low strength } \\
\text { CLSM mixture 2 }\end{array}$ & -- & 658.83 & 681.88 & 547.94 & 566.93 & 616.446 \\
\hline
\end{tabular}

From Table C.4, Average $\left(\mathrm{E}^{\prime}\right)$ for mixture $1=1670 \mathrm{psi}$

Average $\left(\mathrm{E}^{\prime}\right)$ for mixture $2=614.4 \mathrm{psi}$

Value used in FE analysis $\left(\mathrm{E}^{\prime}\right)=1700 \mathrm{psi}$

The back calculated Young's modulus ( $\left.\mathrm{E}^{\prime}\right)$ for mixture 1 and mixture 2 are highly variable. When the average $\left(\mathrm{E}^{\prime}\right)$ for mixture 1 (1670 psi $\approx 1700 \mathrm{psi}$ ) was used in the finite element analysis, the results were in good agreement with laboratory experimental results. 
Table C.5: Measured deflection values for low strength CLSM mixtures at trench width ratio of $2.5\left(\mathrm{~N}_{\mathrm{r}}=2.5\right)$ [See Figure 5.1 and 5.3 (Simmons, 2002)].

\begin{tabular}{|c|c|c|c|c|c|c|}
\hline \multirow[t]{2}{*}{ CLSM mixtures } & \multicolumn{3}{|c|}{$\begin{array}{c}\text { Deflections for } 6 \text { inch HDPE } \\
\text { pipe (in) under surcharge loading }\end{array}$} & \multicolumn{3}{|c|}{$\begin{array}{c}\text { Deflections for } 8 \text { inch HDPE } \\
\text { pipe (in) under surcharge loading }\end{array}$} \\
\hline & $10 \mathrm{psi}$ & 20 psi & $30 \mathrm{psi}$ & $10 \mathrm{psi}$ & 20 psi & $30 \mathrm{psi}$ \\
\hline $\begin{array}{l}\text { Low strength } \\
\text { CLSM mixture1 }\end{array}$ & 0.0473 & 0.0967 & 0.141 & 0.056 & 0.131 & 0.2275 \\
\hline $\begin{array}{c}\text { Low strength } \\
\text { CLSM mixture2 }\end{array}$ & 0.1647 & 0.3354 & 0.4908 & 0.0792 & 0.2561 & 0.4085 \\
\hline
\end{tabular}

Table C.6: Calculated ( $\left.\mathrm{E}^{\prime}\right)$ values for low strength CLSM mixtures at trench width ratio of $2.5\left(\mathrm{~N}_{\mathrm{r}}=2.5\right)$

\begin{tabular}{|c|c|c|c|c|c|c|}
\hline \multirow{2}{*}{ CLSM mixtures } & \multicolumn{3}{|c|}{$\begin{array}{c}\text { Calculated (E') 6 inch HDPE } \\
\text { pipe (psi) under surcharge loading }\end{array}$} & \multicolumn{3}{c|}{$\begin{array}{c}\text { Calculated }\left(E^{\prime}\right) 8 \text { inch HDPE } \\
\text { pipsi) under surcharge loading }\end{array}$} \\
\cline { 2 - 7 } & $10 \mathrm{psi}$ & $20 \mathrm{psi}$ & $30 \mathrm{psi}$ & $10 \mathrm{psi}$ & $20 \mathrm{psi}$ & $30 \mathrm{psi}$ \\
\hline $\begin{array}{c}\text { Low strength } \\
\text { CLSM mixture1 }\end{array}$ & 2340.75 & 2193.2 & 2226.22 & 2663.8 & 2181 & 1856.83 \\
\hline $\begin{array}{c}\text { Low strength } \\
\text { CLSM mixture2 }\end{array}$ & 611.18 & 571.373 & 578.51 & 1858.4 & 1073.78 & 996.13 \\
\hline
\end{tabular}

From Table C.6,

Average $\left(\mathrm{E}^{\prime}\right)$ for mixture $1=2243 \mathrm{psi}$

Average $\left(\mathrm{E}^{\prime}\right)$ for mixture $2=948.23 \mathrm{psi}$

Value used in FE analysis $\left(\mathrm{E}^{\prime}\right)=2250$ psi

The back calculated Young's modulus (E') for mixture 1 and mixture 2 are highly variable. When the average $\left(\mathrm{E}^{\prime}\right)$ for mixture 1 (2243 psi $\approx 2250 \mathrm{psi}$ ) was used in the finite element analysis, the results were in good agreement with laboratory experimental results. 
Table C.7: Measured deflection values for high strength CLSM mixtures at trench width ratio of $1.5\left(\mathrm{~N}_{\mathrm{r}}=1.5\right)$ [See Figure 5.2 and 5.4 (Simmons, 2002)].

\begin{tabular}{|c|c|c|c|c|c|c|}
\hline \multirow[t]{2}{*}{ CLSM mixtures } & \multicolumn{3}{|c|}{$\begin{array}{c}\text { Deflections for } 6 \text { inch HDPE } \\
\text { pipe (in) under surcharge loading }\end{array}$} & \multicolumn{3}{|c|}{$\begin{array}{l}\text { Deflections for } 8 \text { inch HDPE } \\
\text { pipe (in) under surcharge loading }\end{array}$} \\
\hline & $10 \mathrm{psi}$ & $20 \mathrm{psi}$ & $30 \mathrm{psi}$ & $10 \mathrm{psi}$ & $20 \mathrm{psi}$ & $30 \mathrm{psi}$ \\
\hline $\begin{array}{l}\text { Low strength } \\
\text { CLSM mixture1 }\end{array}$ & 0.0245 & 0.0649 & 0.102 & 0.029 & 0.127 & 0.1327 \\
\hline $\begin{array}{l}\text { Low strength } \\
\text { CLSM mixture2 }\end{array}$ & 0.0016 & 0.028 & -- & 0.1808 & 0.3696 & 0.482 \\
\hline
\end{tabular}

Table C.8: Calculated (E') values for high strength CLSM mixtures at trench width ratio of $1.5\left(\mathrm{~N}_{\mathrm{r}}=1.5\right)$

\begin{tabular}{|c|c|c|c|c|c|c|}
\hline \multirow[t]{2}{*}{ CLSM mixtures } & \multicolumn{3}{|c|}{$\begin{array}{c}\text { Calculated (E') } 6 \text { inch HDPE } \\
\text { pipe (psi) under surcharge loading }\end{array}$} & \multicolumn{3}{|c|}{$\begin{array}{l}\text { Calculated }\left(E^{\prime}\right) 8 \text { inch HDPE } \\
\text { pipe (psi) under surcharge loading }\end{array}$} \\
\hline & $10 \mathrm{psi}$ & $20 \mathrm{psi}$ & $30 \mathrm{psi}$ & $10 \mathrm{psi}$ & $20 \mathrm{psi}$ & $30 \mathrm{psi}$ \\
\hline $\begin{array}{c}\text { Low strength } \\
\text { CLSM mixture1 }\end{array}$ & 459.88 & 3309.84 & 3110.17 & 5223.7 & 2252.43 & 3244.56 \\
\hline $\begin{array}{c}\text { Low strength } \\
\text { CLSM mixture2 }\end{array}$ & 71645 & 7784.6 & -- & 765.93 & 717.72 & 831.16 \\
\hline
\end{tabular}

From Table C.8,

Minimum $\left(E^{\prime}\right)=459.88$ psi

Maximum $\left(E^{\prime}\right)=71645$ psi

Value used in FE analysis $\left(\mathrm{E}^{\prime}\right)=1000 \mathrm{psi}$

For the 6 inch HDPE pipe under 10 psi surcharge loading, the back calculated Young's modulus for mixture 1 and mixture 2 are significantly different. When the average value of $E^{\prime}$ was used in the finite element analysis, the comparison between experimental and numerical values was not satisfactory. Therefore, a trail and error method was used to determine the Young's modulus ( $E^{\prime}$ ) for high strength CLSM mixtures with trench width ratio of $1.5\left(\mathrm{~N}_{\mathrm{r}}=1.5\right)$. The finite element results were in good agreement with the laboratory experimental results when $E^{\prime}$ was assumed as 1000 psi. This value falls between the maximum and minimum values shown above. Table C.9: 
Measured deflection values for high strength CLSM mixtures at trench width ratio of 2 $\left(\mathrm{N}_{\mathrm{r}}=2\right)$ [See Figure 5.2 and 5.4 (Simmons, 2002)].

\begin{tabular}{|c|c|c|c|c|c|c|}
\hline \multirow[t]{2}{*}{ CLSM mixtures } & \multicolumn{3}{|c|}{$\begin{array}{c}\text { Deflections for } 6 \text { inch HDPE } \\
\text { pipe (in) under surcharge loading }\end{array}$} & \multicolumn{3}{|c|}{$\begin{array}{l}\text { Deflections for } 8 \text { inch HDPE } \\
\text { pipe (in) under surcharge loading }\end{array}$} \\
\hline & $10 \mathrm{psi}$ & $20 \mathrm{psi}$ & $30 \mathrm{psi}$ & $10 \mathrm{psi}$ & $20 \mathrm{psi}$ & $30 \mathrm{psi}$ \\
\hline $\begin{array}{l}\text { Low strength } \\
\text { CLSM mixture1 }\end{array}$ & 0.0194 & 0.0377 & 0.0566 & 0.0359 & 0.0922 & 0.1425 \\
\hline $\begin{array}{c}\text { Low strength } \\
\text { CLSM mixture2 }\end{array}$ & 0.0245 & 0.069 & -- & 0.0323 & 0.0933 & 0.162 \\
\hline
\end{tabular}

Table C.10: Calculated ( $\left.\mathrm{E}^{\prime}\right)$ values for high strength CLSM mixtures at trench width ratio of $2\left(\mathrm{~N}_{\mathrm{r}}=2\right)$

\begin{tabular}{|c|c|c|c|c|c|c|}
\hline \multirow{2}{*}{ CLSM mixtures } & \multicolumn{3}{|c|}{$\begin{array}{c}\text { Calculated (E') 6 inch HDPE } \\
\text { pipe (psi) under surcharge loading }\end{array}$} & \multicolumn{3}{c|}{$\begin{array}{c}\text { Calculated }\left(E^{\prime}\right) 8 \text { inch HDPE } \\
\text { pipsi) under surcharge loading }\end{array}$} \\
\cline { 2 - 7 } & $10 \mathrm{psi}$ & $20 \mathrm{psi}$ & $30 \mathrm{psi}$ & $10 \mathrm{psi}$ & $20 \mathrm{psi}$ & $30 \mathrm{psi}$ \\
\hline $\begin{array}{c}\text { Low strength } \\
\text { CLSM mixture1 }\end{array}$ & 5577.1 & 5759.6 & 5673.61 & 4203.24 & 3134.93 & 3015.53 \\
\hline $\begin{array}{c}\text { Low strength } \\
\text { CLSM mixture2 }\end{array}$ & 4598.79 & 3108 & -- & 4681.27 & 3096.96 & 2642.2 \\
\hline
\end{tabular}

The back calculated $E^{\prime}$ for the 6 inch HDPE pipe seems to be highly variable, and therefore these values were not considered. The back calculated $E^{\prime}$ values for the 8 inch HDPE pipe for the surcharge loading of 10psi are much higher than the remaining values. Therefore, the average $\mathrm{E}^{\prime}$ was computed based on the remaining values. The average Young's modulus $\left(E^{\prime}\right)$ for high strength CLSM mixtures for 8 inch HDPE pipe at surcharge loads 20 psi and 30 psi is 2972 psi. When the average value (2972 psi $\approx 3000$ psi) was used in the finite element analysis, the results were in good agreement with laboratory experimental results. 
Table C.11: Measured deflection values for high strength CLSM mixtures at trench width ratio of $2.5\left(\mathrm{~N}_{\mathrm{r}}=2.5\right)$ [See Figure 5.2 and 5.4 (Simmons, 2002)].

\begin{tabular}{|c|c|c|c|c|c|c|}
\hline \multirow[t]{2}{*}{ CLSM mixtures } & \multicolumn{3}{|c|}{$\begin{array}{c}\text { Deflections for } 6 \text { inch HDPE } \\
\text { pipe (in) under surcharge loading }\end{array}$} & \multicolumn{3}{|c|}{$\begin{array}{l}\text { Deflections for } 8 \text { inch HDPE } \\
\text { pipe (in) under surcharge loading }\end{array}$} \\
\hline & $10 \mathrm{psi}$ & $20 \mathrm{psi}$ & $30 \mathrm{psi}$ & $10 \mathrm{psi}$ & $20 \mathrm{psi}$ & $30 \mathrm{psi}$ \\
\hline $\begin{array}{c}\text { Low strength } \\
\text { CLSM mixture1 }\end{array}$ & 0.031 & 0.0527 & 0.0699 & 0.0269 & 0.0671 & 0.106 \\
\hline $\begin{array}{c}\text { Low strength } \\
\text { CLSM mixture2 }\end{array}$ & 0.0071 & 0.037 & -- & 0.0099 & 0.0454 & 0.0856 \\
\hline
\end{tabular}

Table C.12: Calculated (E') values for high strength CLSM mixtures at trench width ratio of $2.5\left(\mathrm{~N}_{\mathrm{r}}=2.5\right)$

\begin{tabular}{|c|c|c|c|c|c|c|}
\hline \multirow{2}{*}{ CLSM mixtures } & \multicolumn{3}{|c|}{$\begin{array}{c}\text { Calculated (E') 6 inch HDPE } \\
\text { pipe (psi) under surcharge loading }\end{array}$} & \multicolumn{3}{c|}{$\begin{array}{c}\text { Calculated }\left(E^{\prime}\right) 8 \text { inch HDPE } \\
\text { pipsi) under surcharge loading }\end{array}$} \\
\cline { 2 - 7 } & $10 \mathrm{psi}$ & $20 \mathrm{psi}$ & $30 \mathrm{psi}$ & $10 \mathrm{psi}$ & $20 \mathrm{psi}$ & $30 \mathrm{psi}$ \\
\hline $\begin{array}{c}\text { Low strength } \\
\text { CLSM mixture1 }\end{array}$ & 3616.57 & 4095.9 & 4577.78 & 5638.2 & 4339.67 & 4083.38 \\
\hline $\begin{array}{c}\text { Low strength } \\
\text { CLSM mixture2 }\end{array}$ & 16079.01 & 5870.24 & -- & 15467.12 & 6454.87 & 5076.9 \\
\hline
\end{tabular}

From Table C.12,

Minimum $\left(E^{\prime}\right)=3616.6$ psi

$\operatorname{Maximum}\left(E^{\prime}\right)=16079 \mathrm{psi}$

Average $\left(E^{\prime}\right)=6178$ psi (excluding the maximum and minimum values)

Value used in FE analysis $\left(\mathrm{E}^{\prime}\right)=6200 \mathrm{psi}$

For the 6 inch and 8 inch HDPE pipes under 10psi surcharge loading, the Young's modulus values for mixture 1 and mixture 2 are significantly different. Since the values are highly variable, an average $\mathrm{E}^{\prime}$ value was calculated by excluding the maximum and the minimum values. When the $\mathrm{E}^{\prime}$ value of $6200 \mathrm{psi}$ ( $\left.6178 \mathrm{psi} \approx 6200 \mathrm{psi}\right)$ was used, the finite element results were in good agreement with that of the laboratory experimental results. 